\begin{abstract}
UNIVERSIDADE DE SÃO PAULO
FACULDADE DE FILOSOFIA, LETRAS E CIÊNCIAS HUMANAS

DEPARTAMENTO DE LETRAS CLÁSSICAS E VERNÁCULAS

PROGRAMA DE ESTUDOS COMPARADOS DE LITERATURAS DE LÍNGUA PORTUGUESA
\end{abstract}

TATIANE REGHINI DE MATTOS

Narradora e ideologia em Lúcia Miguel Pereira e Maria Lamas:

os anos 1930

(versão corrigida)

São Paulo

2018 


\author{
UNIVERSIDADE DE SÃO PAULO \\ FACULDADE DE FILOSOFIA, LETRAS E CIÊNCIAS HUMANAS \\ DEPARTAMENTO DE LETRAS CLÁSSICAS E VERNÁCULAS
}

Narradora e ideologia em Lúcia Miguel Pereira e Maria Lamas:

os anos 1930

Tatiane Reghini de Mattos

Tese apresentada ao Programa de PósGraduação em Estudos Comparados de Literaturas de Língua Portuguesa da Faculdade de Filosofia, Letras e Ciências Humanas da Universidade de São Paulo, para a obtenção do título de Doutora em Letras.

Orientadora: Profa. Dra. Rejane Vecchia da

Rocha e Silva

(versão corrigida)

São Paulo

2018 
Autorizo a reprodução e divulgação total ou parcial deste trabalho, por qualquer meio convencional ou eletrônico, para fins de estudo e pesquisa, desde que citada a fonte.

Catalogação na Publicação

Serviço de Biblioteca e Documentação

Faculdade de Filosofia, Letras e Ciências Humanas da Universidade de São Paulo

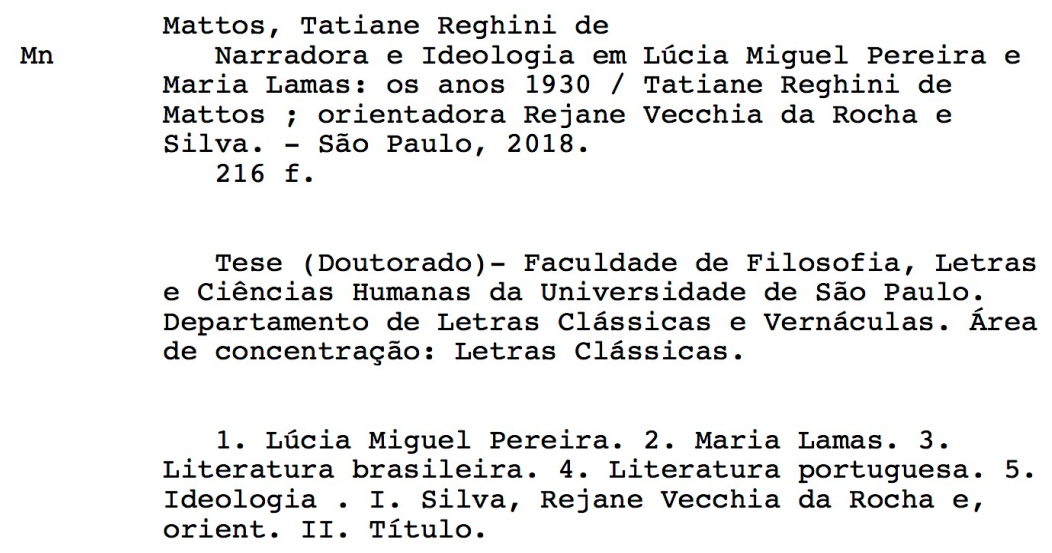

1. Lúcia Miguel Pereira. 2. Maria Lamas. 3. Literatura brasileira. 4. Literatura portuguesa. 5. Ideologia. I. Silva, Rejane Vecchia da Rocha e, orient. II. Título. 


\section{ENTREGA DO EXEMPLAR CORRIGIDO DA DISSERTAÇÃO/TESE}

Termo de Ciência e Concordância do (a) orientador (a)

Nome do (a) aluno (a): Tatiane Reghini de Mattos

Data da defesa: 08/02/2019

Nome do Prof. (a) orientador (a): Rejane Vecchia da Rocha e Silva

Nos termos da legislação vigente, declaro ESTAR CIENTE do conteúdo deste EXEMPLAR CORRIGIDO elaborado em atenção às sugestões dos membros da comissão Julgadora na sessão de defesa do trabalho, manifestando-me plenamente favorável ao seu encaminhamento e publicação no Portal Digital de Teses da USP.

São Paulo, 08/04/2019

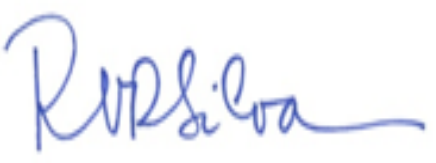

Rejane Vecchia da Rocha e Silva Orientadora 
MATTOS, Tatiane Reghini de

Narradora e Ideologia em Lúcia Miguel Pereira e Maria Lamas: os anos 1930.

Tese apresentada ao Programa de PósGraduação em Estudos Comparados de Literaturas de Língua Portuguesa da Faculdade de Filosofia, Letras e Ciências Humanas da Universidade de São Paulo, para a obtenção do título de Doutora em Letras.

Aprovado em: 08/02.2019

\section{Banca Examinadora}

Profa. Dra. Rejane Vecchia da Rocha e Silva Instituição: DLCV/USP

Julgamento:

Assinatura:

Profa. Dra. Márcia Zamboni Gobbi

Instituição: UNESP

Julgamento:

Assinatura:

Profa. Dra. Paola Poma

Instituição: DLCV/USP

Julgamento:

Assinatura:

Prof. Dr. Daniel Puglia

Instituição: DLM/USP

Julgamento:

Assinatura:

Prof. Dr. Daniel Reizinger Bonomo

Instituição: UFMG

Julgamento:

Assinatura: 


\section{AGRADECIMENTOS}

Agradeço à minha orientadora Rejane Vecchia da Rocha e Silva, pela atenção na orientação e a amizade de sempre.

À coorientadora desta tese, Profa. Dra. Maria Isabel Pires de Lima.

À Margarete, ao Claudio, à Natalie e ao Claudio Jr., pelo apoio durante toda a trajetória.

À Joana Souto, à Giselle Rocha, à Silvia Nogueira, à lana Souza, à Rosana Baú, que contribuíram diretamente com esta tese. Às amigas e aos amigos que acompanharam o processo ao longo desses anos e comigo trocaram na academia e na vida.

Especialmente, a todas as mulheres que me cercam e que comigo dividiram e dividem experiências e impressões sobre nossas próprias vidas.

À minha avó Elenice.

À CAPES pelas bolsas que financiaram esta pesquisa. 
À avó Nice 


\section{RESUMO}

MATTOS, Tatiane Reghini de. Narradora e ideologia em Lúcia Miguel Pereira e Maria Lamas: os anos 1930. 2018, 216 f. Tese (Doutorado) - Faculdade de Filosofia Letras e Ciências Humanas, da Universidade de São Paulo, São Paulo, 2018.

A presente pesquisa tem por objetivo a análise comparada dos romances Maria Luísa e Amanhecer, de Lúcia Miguel Pereira e Para além do amor e A Ilha Verde, de Maria Lamas, publicados durante os anos 1930. Considera-se como hipótese a presença da perspectiva ideológica, amparada por certa estrutura patriarcal, por um lado, e feminista, por outro, que desvenda uma narradora em diálogo com o contexto social e histórico a que estão circunscritos os romances.

Palavras-chaves: Lúcia Miguel Pereira; Maria Lamas; literatura brasileira; literatura portuguesa; romance; feminismo; ideologia. 


\begin{abstract}
MATTOS, Tatiane Reghini de. Female narrators and ideology in the works of Lúcia Miguel Pereira and Maria Lamas: in the 1930s. 2018, 216f. Thesis (PhD) - Faculty of Philosophy, Languages and Literature, an Human Sciences (FFLCH), University of São Paulo, São Paulo, 2018.
\end{abstract}

This research aims at the comparative analysis of the novels Maria Luísa andAmanhecer by Lúcia Miguel Pereira, and Para além do amor and A Ilha Verde by Maria Lamas, published during the 1930s. Be regarded as hypothesis the presence of the ideological perspective supported by a certain patriarchal structure, on one hand, and the feminist perspective, on the other, that unveils a narrator in dialogue with both social and historical contexts into which the novels are circumscribed.

Keywords: Lúcia Miguel Pereira; Maria Lamas; Brazilian literature; Portuguese literature; novel; feminism; ideology. 


\section{SUMÁRIO}

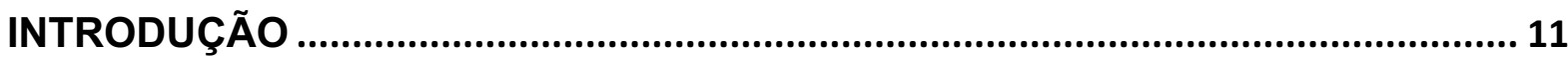

CAPÍTULO I - Maria Luísa e Para Além do amor: a perspectiva da mulher

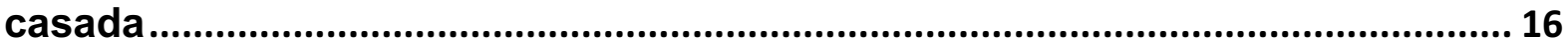

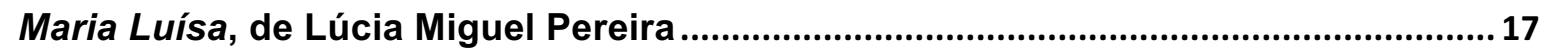

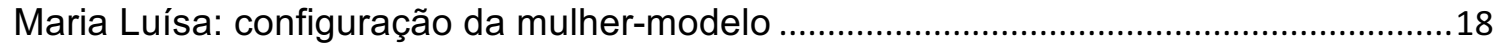

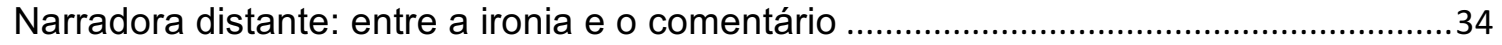

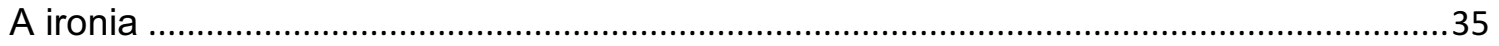

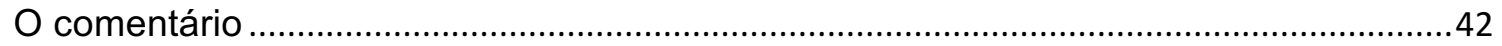

Orquestração do feminino e a transfiguração da outra: a narradora com Maria Luísa..46

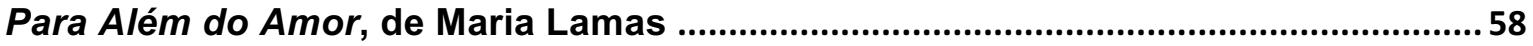

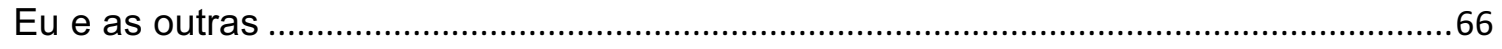

O outro-homem como intermédio e a figuração do patriarcal ...........................................71

Um ponto de vista feminista: entre a ação e a resignação..................................................75

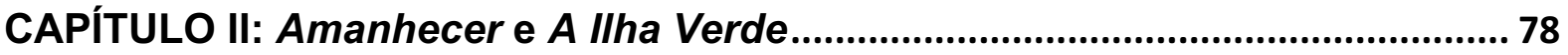

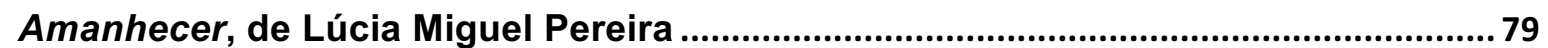

A orquestração do espectro feminino: a tríade aqui como a tríade de lá..........................83

A configuração patriarcal na presença masculina em Amanhecer ....................................89

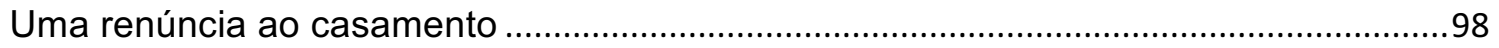

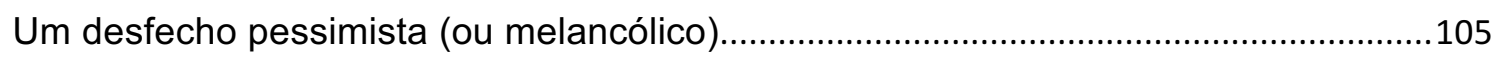

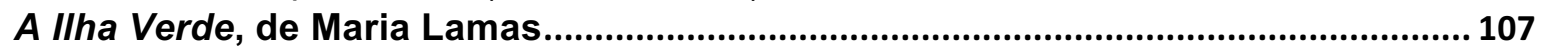

Lugar social da protagonistas e esboços da narradora ..................................................109

Orquestração do feminino das personagens: Maria Luíza, Isabel e D. Brites.................117

A figuração do patriarcal nas personagens masculinas em A Ilha Verde ........................124

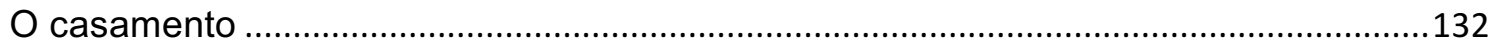

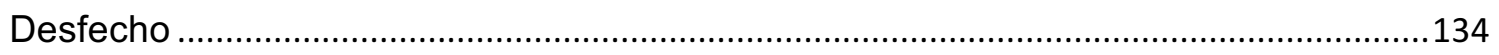

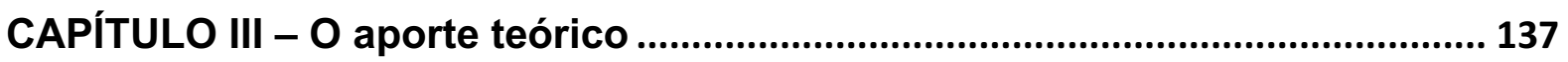

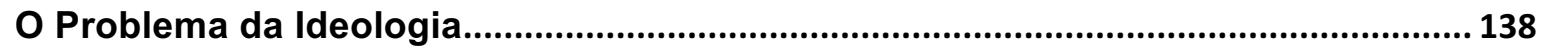

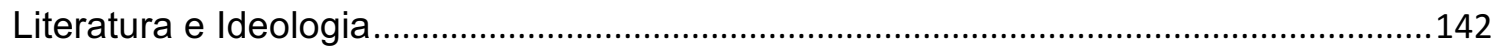

Ideologia patriarcal e ideologia feminista nas estruturas narrativas: o casamento.......145

Papel social da mulher na sociedade de mentalidade patriarcal ............................... 147

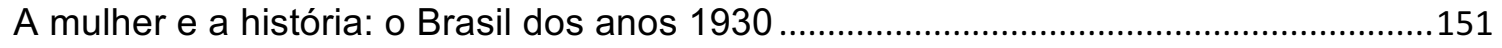

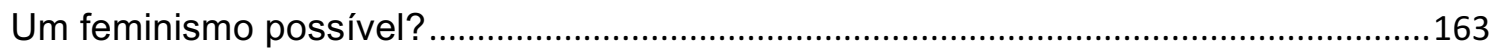

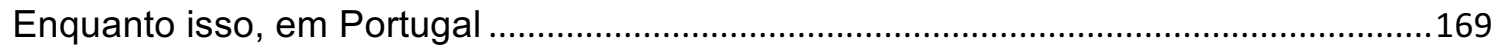

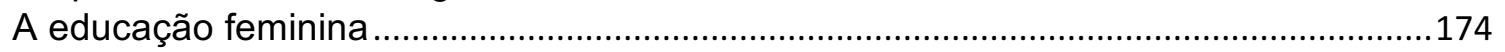

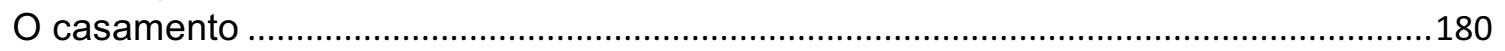

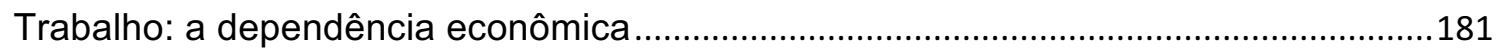

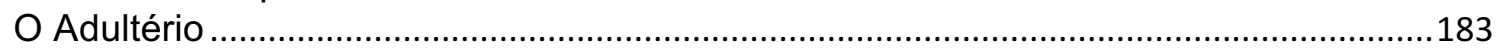

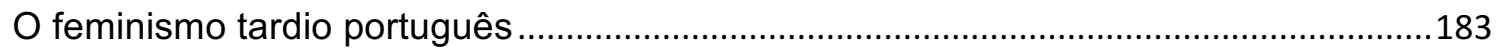

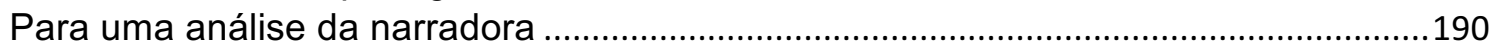

CAPÍTULO IV - As autoras implícitas e as narradoras .................................... 191

A narradora e a autora implícita: ideologia e história na estrutura narrativa ........... 192

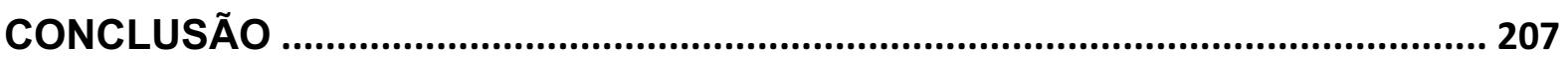

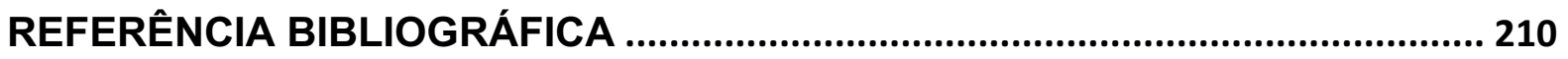




\section{INTRODUÇÃO}

Lúcia Miguel Pereira nasceu em Barbacena (MG), por acaso, em 1901, durante férias de sua família que morava no Rio de Janeiro, onde residiu até a sua morte. No Colégio Sion, teve uma formação de bases católicas, e lá iniciou seus estudos de literatura e colaborou com uma primeira publicação, junto a outras estudantes do colégio. Inscreveu-se na crítica literária brasileira de maneira autodidata, desafiando o que no período era ainda um reduto masculino. Como crítica literária, adquiriu enorme prestígio com a publicação de Machado de Assis: estudos críticos e biográficos, em 1936, quando já contribuía com textos críticos em revistas como o Boletim de Ariel e Revista do Brasil, além da Revista Feminina. Exerceu crítica ainda nos jornais O Correio da Manhã e O Estado de São Paulo, no qual guiava um suplemento literário. Publicou a biografia de Gonçalves Dias, em 1943.

Como crítica literária publicou ainda Prosa e ficção de 1870 a 1920, organizou O livro de centenário de Eça de Queiroz (1945) e publicou Cinquenta anos de literatura, em 1952. Entre outros trabalhos, traduziu O tempo redescoberto de Marcel Proust. Escreveu também livros infantis. Lúcia morreu em dezembro de 1959, numa colisão entre aeronaves, quando voltava de São Paulo para o Rio de Janeiro, aos 58 anos. Postumamente, algumas de suas críticas foram reunidas em livros, como $A$ leitora e seus personagens (1931-1943) e Escritos da maturidade (1944-1959). Como romancista, publicou quatro livros: Maria Luísa e Em Surdina (de 1933), Amanhecer (1938) e Cabra Cega (1954). Casou-se com o historiador e escritor Octávio Tarquínio de Sousa, um homem desquitado naquele início de anos 1930 no Brasil, desafiando assim os padrões da época, ao se casar "mais velha" e com um homem divorciado. Além disso, não teve filhos.

Maria Lamas nasceu em 1893 como Maria da Conceição Vassalo e Silva, em Torres Novas, Portugal. Assim como Lúcia Miguel Pereira e as outras mulheres do período com acesso à educação, estudou em colégio católico ${ }^{1}$. Divorciou-se pela

\footnotetext{
1 "Acreditei nos valores que me transmitiam, (inclusive que o Diabo se enrolava às saias das mulheres que dançavam) até ao dia em que me quiseram obrigar a mistificar o meu dia-a-dia. Nesse momento, bruscamente, perdi a fé. Foi a minha primeira viragem" (BIBLIOTECA Nacional, 1993, p. 11).
} 
primeira vez aos 25 anos, já com duas filhas e assim iniciou a sua carreira de jornalista, como responsável pelas páginas infantis do Correio da Manhã e da Epóca. Em 1923, publicou Os Humildes, sob o pseudônimo de Rosa Silvestre, com o qual também assinaria Diferença de Raças (1924) e Caminhos Luminosos (1928). Passou então a colaborar como jornalista no jornal O Século, onde assumiu, em 1928, a direção do suplemento feminino Modas e Bordados. Neste suplemento, que tem características dos suplementos femininos da época, como dicas de vestuário, comportamento e questões da família etc, Maria Lamas inovou acrescentando-Ihe o título Vida Feminina, cuja proposta era a reflexão sobre os problemas das mulheres. Também neste suplemento passou a apresentar mulheres artistas e intelectuais da época, dedicando uma página a cada edição para biografias. Separou-se pela segunda vez em 1929, divorciando-se efetivamente apenas anos mais tarde, de Alfredo Lamas, de quem adotou o sobrenome.

Em 1930, foi responsável pela Exposição de Obras Femininas: antiga e moderna de caráter literário, artístico e científico. Esta primeira exposição foi bastante importante na vida cultural lisboeta e fez sucesso. O objetivo era expor o trabalho da mulher portuguesa, desde a produção artesã até a intelectual. Publicou, em 1935, Para além do amor, assinando pela primeira vez como Maria Lamas. $A$ Ilha Verde foi publicado três anos depois. Durante a Segunda Guerra, respondeu às questões de mulheres jovens como Tia Filomena, no Correio da Joaninha. Maria Lamas foi eleita presidente do Conselho Nacional das Mulheres Portuguesas em 1945. Em janeiro de 1947, com a sua articulação, foi organizada a Exposição Livros Escritos por Mulheres, na Sociedade Nacional de Belas Artes. Esta exposição apresentava a produção intelectual (não só ficcional) de diversas mulheres. Em seu catálogo encontramos desde obras artísticas até pesquisa das áreas biológicas, exatas e humanas ${ }^{2}$. Perseguida por Salazar, foi demitida de O Século, no mesmo momento em que o governo fechava o Conselho. Maria Lamas iniciou então uma viagem por Portugal procurando conhecer a vida das mulheres portuguesas, o que deu origem ao Mulheres do meu país.

Foi presa pela ditadura salazarista em 1949 (por alguns dias), em 1950 (por seis meses) e em 1953, quando pagou uma cara fiança. Publicou em 1952 As

\footnotetext{
${ }^{2}$ Em seu catálogo, constam nomes de brasileiras como Albertina Berta, Julia Lopes de Almeida, Clarice Lispector, Gilka de Costa Melo Machado, Cecília Meireles, Adalgisa Nery, Raquel de Queiroz, Lúcia Miguel Pereira.
} 
mulheres no mundo, como resultado de um trabalho de pesquisa de 20 anos. Em 1962, cansada das perseguições salazarista, exilou-se em Paris, aos 68 anos, regressando a Portugal apenas em 1969. Traduziu Os miseráveis, de Victor Hugo, entre outros. Voltou a ser diretora de Modas e Bordados depois do 25 de abril e morreu aos 90 anos, em 1983.

São essas duas mulheres que escreveram os romances objetos de estudo desta tese. Em suas obras ficcionais, as mulheres serão sempre protagonistas, em diálogos com outras personagens femininas e em contraposição a dada ordem social que opera sobre elas. Há, nos romances, uma figuração da ideologia patriarcal que será contestada, como procuraremos apresentar, assim como há uma profusão da ideologia feminista do período. Para realizar esta análise, no entanto, torna-se fundamental o respaldo da crítica literária feminista que se não denotará às questões formais o que se pode definir como uma narradora, ajuda a elucidar isso a partir da injunção dessas duas ideologias na configuração de suas vozes narrativas. Sobre a crítica literária feminista, cabe ressaltar que:

Whereas it had always been taken for granted that the representative reader, writer, and critic of Western literature is male, feminist criticism has shown that women readers and critics bring different perceptions and expectations to their literary experience, and has insisted that women have also told the important stories of our culture. (...) Whether concerned with the literary representations of sexual difference, with the ways that literary genres have been shaped by masculine or feminine value, or with the exclusion of the female voice from the institutions of literature, criticism and theory, feminist criticism has established gender as a fundamental category of literary analysis. (SHOWALTER, 1985, p. 3)

Assim, contribuem as autoras implícitas para a perscrutação dessas ideologias, que organizam os romances determinando o ponto de vista sob o qual as histórias serão contadas. Forjam então nas vozes narrativas a contestação, sobre a qual falou Manonni ao analisar as escritoras inglesas do final do século XIX, em Elas não sabem o que dizem: 
Sob a roupagem da "loucura", uma voz de mulher insiste e expressa a sua recusa à "adaptação social". Ela se entedia numa sociedade sem alma, de prazeres rotineiros, e denuncia o inferno cotidiano a que alguns casais são condenados. O que ela pede ao outro é uma falta na qual pudesse ter lugar. A mulher contestatária, afirmando-se na sua diferença, incomoda a ordem estabelecida.

As mulheres são consideradas como formando um grupo social distinto. É desse lugar que elas são "autorizadas" ou impedidas de ter acesso a determinada função reservada até então aos homens, ou de gozar de algum de seus privilégios. (MANONNI, 1999, p. 9596)

Dessa forma, sobre os romances aqui analisados recairá sempre a questão do casamento, muito cara ao feminismo da época, por ser responsável, ao mesmo tempo, por certa emancipação da mulher, que sai da dependência da família para ter a própria família, e a prisão dessa mesma mulher, agora cerceada em sua função de esposa e mãe. As narrativas se estruturam a partir de certa contestação ao casamento e assim vamos acompanhando a ideologia da narradora. Por isso, por existir um lugar ideológico explicitamente definido a partir da condição social da mulher, torna-se possível a leitura da perspectiva de gênero nestas narrativas, inclusive naquelas que se desenvolvem em terceira pessoa.

Esta marca de gênero, no entanto, não se revela em seu aspecto formal. No que tange os aspectos formais narrativos, podemos chamar esta entidade narrativa apenas de narrador ou narrador indefinido, como vem sendo feito em algumas análises dos romances aqui estudados. Também esta definição através da forma só seria possível se assumíssemos, de antemão, que há uma marca diferencial na forma de escrever de um homem e de uma mulher, assunto esse já tão caro aos estudos críticos feministas. No entanto, se admitimos as marcas ideológicas que incidem sobre as narradoras, bem como suas formulações a partir das autoras implícitas e mudamos a perspectiva de análise, observando nas condicionantes sociais de gênero as diferenças que essas marcas implicam, encontramos elementos que pensamos comprovar nossa tese.

Para observarmos os eixos que estruturam esses romances, e que apresentam uma condição de vida da mulher, é necessário que apelemos para a 
intersecção entre literatura e história, uma vez que é no estudo da história das mulheres desses dois países que tais condições são especificadas. A partir disso, tentou-se tecer as proximidades e distanciamentos entre esses quatro romances, com um primeiro recorte feito pela escolha temporal, os anos 1930, e um segundo respeitando um eixo temático. Sendo assim, compara-se, em capítulos separados, Maria Luísa (1933), de Lúcia Miguel Pereira e Para além do amor (1935), de Maria Lamas, cujos enredos perpassam a história de mulheres que vivenciam o adultério e a partir dele passam por um processo de conscientização de gênero. A seguir, Amanhecer (1938), de Lúcia Miguel, e A Ilha Verde (1938), de Maria Lamas, que trazem como protagonistas mulheres que se recusam a casar. Seguindo esse recorte temático, exclui-se desta análise comparativa o romance Em Surdina, de Lúcia Miguel Pereira, também publicado no ano de 1933.

No capítulo final desta tese, comparamos as autoras implícitas e narradoras, observando mais atentamente o foco narrativo e as ideologias que permeiam este foco. Para tanto, invertemos a ordem do recorte temporal, começo e final dos anos 1930, entre os romances e analisamos conforme o ponto de vista da narradora, além de apontar para as inscrições dos romances em suas especificidades históricas, que também criam aproximações e distanciamentos entre os escritos por Lúcia Miguel e os escritos por Maria Lamas.

Ninguém nasce mulher: torna-se mulher.
Nenhum destino biológico, psíquico,
econômico define a forma que a fêmea
humana assume no seio da sociedade; é o
conjunto da civilização que elabora esse
produto intermediário entre o macho e o
castrado, que qualificam de feminino.
(BEAUVOIR, 2016b, p. 11)


CAPÍTULO I - Maria Luísa e Para além do amor: a perspectiva da mulher casada 


\section{Maria Luísa, de Lúcia Miguel Pereira}

Maria Luísa foi publicado numa época em que Lúcia Miguel Pereira já era reconhecida no universo da crítica literária, cujo contexto era bastante masculino ${ }^{3}$. No entanto, sua estreia como romancista foi cerceada por certo silêncio ${ }^{4}$, que, não obstante, perdurou no século XX. Seus dois romances publicados em 1933, Maria Luísa e Em Surdina, acabam por evidenciar o conflito entre antigos e novos paradigmas que figuram na sociedade de 1930, no que tange à condição de vida da mulher brasileira pertencente a determinado grupo social, a partir de um eixo central que é o casamento.

O protagonismo feminino é organismo fundamental na obra de Lúcia Miguel Pereira, estando presente na estruturação de Maria Luísa, bem como em toda sua produção de prosa ficcional até os anos 1950, quando publica Cabra Cega. Nesse romance, que traz a história da personagem homônima, casada com um burguês ${ }^{5}$, mãe de dois filhos, oriunda de uma família falida da elite carioca e que se defrontará com a consciência dos limites que Ihe são imputados por uma sociedade burguesa de ideologia patriarcal ${ }^{6}$, surgem personagens que configuram um panorama no qual é possível perceber as condições e contradições que delimitaram a vida de determinado grupo de mulheres daquela sociedade.

\footnotetext{
3 "Lúcia Miguel Pereira, além de romancista e jornalista consagrada, foi pioneira na crítica literária, um reduto até então exclusivamente masculino" (ALMEIDA, 2011, p. 17).

${ }^{4}$ Não queremos dizer com isso que não foram realizadas críticas em jornais ou suplementos literários sobre seus romances. Tangenciamos esse silenciamento à historiografia do romance do período em que se inscrevera. É notável, porém, que a partir do final do século XX surgem as primeiras pesquisas acadêmicas, na maioria das vezes realizadas por pesquisadoras, que debruçam-se sobre seus romances, mais especificamente. Além disso, atualmente, constam dois de seus romances Maria Luísa e Amanhecer em Uma história do romance de 30, de Luís Bueno, importante referência com notável relevância para os estudos do romance brasileiro dos anos 1930 .

${ }^{5}$ Tal qual define sua narradora. Artur, no entanto, realmente se afina com a proposição burguesa da época: um homem de família estrangeira pobre que ascende no território brasileiro.

${ }^{6}$ Embora seja conhecida a problemática do termo patriarcado para o debate feminista atual, colocamo-nos aqui de acordo com a defesa do uso do conceito enquanto forma de expressão do poder político (SAFFIOTTI, 2015, p. 58). Segundo Saffioti, "À medida que as(os) teóricas(os) feministas forem se desvencilhando das categorias patriarcais, não apenas adquirirão poder para nomear de patriarcado o regime atual de relações homem-mulher, como também abandonarão a acepção de poder paterno do direito patriarcal e o entenderão como direito sexual. Isso equivale a dizer que o agente social marido se constitui antes que a figura do pai. Esta se encontra atenuada nas sociedades complexas contemporâneas, mas ainda é legítimo afirmar-se que se vive sob a lei do pai. Todavia, a figura forte é a do marido, pois é ela que o contrato sexual dá à luz. O patria potestas cedeu espaço, não à mulher, mas aos filhos (SAFIOTTI, 2015, p. 59).
} 
Além disso, sobressai-se neste romance um ponto de vista da mulher que elucubrará uma voz narrativa feminina, como tentaremos apontar. É através, portanto, do que entendemos como ideologia presente na narradora que se configura uma voz que traduz certa experiência social da mulher no romance. Reiteramos a especificidade desta experiência, uma vez que Maria Luísa faz parte de uma determinada categoria social, que não se consolida apenas como gênero, mas também como raça (uma mulher branca) e classe (uma mulher pertencente à elite econômica). É através dessa experiência específica (e muitas vezes em contraste com ela) que se firmará uma perspectiva crítica na voz narrativa.

No intuito do desempenho de maior fluidez analítica, parece-nos essencial olhar para duas proposições distintas relacionadas à perspectiva da narradora, uma vez que essa se apresenta a princípio distante da protagonista para, a seguir, aproximar-se a ponto de se confluir, conforme buscaremos apresentar. Existe, portanto, uma diferenciação de ponto de vista narrativo na estruturação do romance: enquanto na primeira parte, quando Maria Luísa representa a mulher modelo esposa-mãe dentro do sistema patriarcal e burguês em que transita, a narradora mantém de si uma perspectiva distante, apontando ironicamente para sua conjunção; na segunda parte, quando recaem sobre Maria Luísa as dúvidas relacionadas a esse mesmo sistema no que concerne a sua atuação como mulher, a narradora de si se aproxima, abrindo mão de sua característica fundamentalmente irônica da primeira metade da narrativa e diluindo a distância de perspectiva existente entre sua voz e a voz da protagonista (a voz da outra), recorrendo, principalmente, ao discurso indireto livre.

\section{Maria Luísa: configuração da mulher-modelo}

Na cena inicial do romance, temos contato com o ambiente do qual partirá a voz narrativa, a princípio. A narradora apresenta Maria Luísa através do olhar de Artur: "Era um velho hábito e ela uma senhora metódica". Além disso, há a caracterização da narradora de sociedade moderna "A corrida atrás do tempo é uma das torturas da vida moderna" (p. 13), e a definição da classe na qual sob a qual 
será construída a protagonista que é iluminada através do comportamento de Maria Luísa com a cozinheira que prestava serviço em sua casa:

- Parece que foi de propósito, explicou ao marido; a cozinheira não contava mais comigo, a esta hora. Pilhei-a com a boca na botija, dando um embrulho de mantimentos a um molecote, seu filho, com certeza. Já está despedida... não quero nem que faça o jantar... um desaforo! (PEREIRA, 2006, p. 13)

Assim, temos nos três primeiros parágrafos do romance estabelecida a condição social de Maria Luísa: ela é transpassada por uma estrutura patriarcal (traduzida neste início por sua caracterização feita de saída por um marido) e está inserida no contexto burguês, que mais adiante saberemos carioca, mas que aqui já está exposto através do olhar crítico da narradora traduzido por uma dicotomia entre o pecado relacionado ao atraso à missa e o comportamento autoritário com a cozinheira: uma mulher que cumpre protocolo religioso, sem no entanto compadecer-se da próxima.

O conjunto feminino do romance será ordenado transversalmente pela protagonista e, desta forma, sua figura será composta, na primeira parte narrativa, através das diversas caracterizações de outras personagens que a si emergem como contraste. Duas principais: Lola (a cunhada) e dona Constância (a mãe), que delineiam determinados aspectos da condição social de vida feminina, delimitada no locus acima mencionado, que ali estruturam uma espécie de mosaico desse universo, em um espectral feminino, apresentando suas contradições.

Conforme nos alerta Edwirges Almeida:

$\mathrm{Na}$ construção de uma sociedade particular que sobressalta da problemática familiar, tomamos, num processo metonímico, a dialética dessas relações familiares, delineadas por uma "revolução" psicológica, para entender o conflito feminino da sociedade carioca do período, evidente no romance de Maria Luísa. Se é fato que a mulher, nesse período, ainda tem sua voz emudecida pelas ideias e práticas masculinas, a grande transformação se dá, de fato, no pensamento. Narrativa tematizada pelas reflexões e crises existenciais da personagem Maria Luísa, ao seguir ou sugerir uma 
trajetória feminina na busca da sua liberdade, depara-se com a consciência feminina da necessidade da mudança. Essa consciência é alcançada através da relação de alteridade entre os sujeitos. É por meio da observação do outro que as personagens se conhecem e se reconhecem configurando intensas epifanias ao longo do texto. (ALMEIDA, 2009, p. 232)

Assim, temos que cada uma das figuras femininas se apresenta com uma especificidade que, se a princípio contrasta com a personalidade de Maria Luísa em relação aos padrões comportamentais estabelecidos, na segunda parte do romance organizará sua nova perspectiva, na qual as particularidades das outras são impressas, formando um todo que viabiliza a consciência de sua condição de mulher. Assim, a trajetória de conscientização de Maria Luísa, ou mudança no pensamento, conforme apontada acima por Almeida, coincidirá com a consciência de uma certa experiência coletiva de gênero, cuja inflexão colidirá em uma das instituições que viabiliza a opressão dessa mulher: o casamento. Portanto, à divisão em duas partes no romance, nomeadamente Parte I e Parte II, A montanha (que na ação narrativa estão demarcadas pelo antes e depois de vivenciar o adultério) está atrelada a divisão de duas Maria Luísa, uma que se enxerga individualmente, e que é caracterizada principalmente por uma narradora irônica que aponta para o olhar das outras e do outro (o marido) sobre si, e outra que se vê parte de um todo maior e mais complexo, respaldada pela narradora cuja perspectiva converge, apontando, para o olhar da própria Maria Luísa, que aqui se movimenta em conteste com as hipócritas relações sociais que emergem em torno de si. É importante ainda destacar que é o posicionamento de Maria Luísa que entrará em contraste com o comportamento das outras.

$\mathrm{Na}$ primeira parte da narrativa, temos, portanto, uma Maria Luísa que se posiciona diante das determinações sociais que a rodeiam, inclinada a ser um exemplo de esposa, ainda que o casamento não tenha sido o "deslumbrante panorama" (p. 28) que imaginou, e um exemplo de mãe, a ponto de qualquer falta dos filhos a humilharem (p. 33). Sendo assim, Maria Luísa projeta no romance o ideal da mulher brasileira dos anos 1930 no que se refere aos padrões que buscavam viabilizar certa modernização feminina sem, no entanto, alterar sua função primordial como sendo a de esposa e mãe, na garantia da manutenção da 
ordem através da instituição família como parte das políticas públicas do período ${ }^{7}$, que conglomeram esforços de várias esferas, eugenistas e católicas, que, em se contradizendo em diversos pontos, concordavam na definição de função da mulher, como nos alerta Susan Besse:

Da década de 1920 até a de 1930, a enorme influência da eugenia ao mesmo tempo "ciência" e movimento social preocupado com o aperfeiçoamento da "raça"- concentrava-se na reprodução como forma de superar o suposto "atraso" e "degeneração" do país. Assim, casamento, sexualidade, maternidade e educação feminina assumiam, a seus olhos, enorme importância. Ao mesmo tempo, os intelectuais urbanos mais conservadores colocavam sua energia na revitalização do catolicismo como poderosa força de reação para deter a maré crescente das teorias científicas modernas, dos movimentos democráticos e da moda moderna, "imoral". E conseguiram êxito na mobilização de milhares de católicos nos movimentos leigos. Militantemente antifeministas, essas organizações exigiam a rigorosa adesão aos dogmas e moralidade tradicionais da Igreja. Porém, se a visão racionalista e secular dos eugenistas sobre reprodução "higiênica", "puericultura" e educação "eugênica" frequentemente se chocava com a insistência dos ativistas católicos em defender a base religiosa da vida e da educação familiares, uns e outros concordavam em que os papéis primordiais e essenciais das mulheres eram os de esposa e mãe. $\mathrm{E}$ compartilhavam da convicção de que a regeneração nacional (e o futuro do Brasil como potência nacional) dependia da saúde moral e física de cada uma de suas famílias. (BESSE, 1999, p. 3, grifo nosso).

Tal conformidade estava ainda de acordo com o que já era vigente a partir do final do século anterior, como nos alerta Maria Ângela D'Incao:

\footnotetext{
7 "De meados da década de 1910 até princípios da de 1940 surgiu, entre os mais eminentes intelectuais e profissionais do Brasil, um consenso esmagador segundo o qual o triunfo da "civilização e o progresso" na esfera pública dependia da "salvação" da família" (BESSE, 1999, p. $63)$.
} 
Durante o século XIX, a sociedade brasileira sofreu uma série de transformações: a consolidação do capitalismo; o incremento de uma vida urbana que oferecia novas alternativas de convivência social; a ascensão da burguesia e o surgimento de uma nova mentalidade burguesa - reorganizadora das vivências familiares e domésticas, do tempo e das atividades femininas; e, por que não, a sensibilidade e a forma de pensar o amor.

Presenciamos ainda nesse período o nascimento de uma nova mulher nas relações da chamada família burguesa, agora marcada pela valorização da intimidade e da maternidade. Um sólido ambiente familiar o lar acolhedor, filhos educados e esposa dedicada ao marido, às crianças e desobrigada de qualquer trabalho produtivo representavam o ideal de retidão e probidade, o tesouro social imprescindível. Verdadeiros emblemas desse mundo relativamente fechado, a boa reputação financeira e a articulação com a parentela como forma de proteção ao mundo externo também marcaram o processo de urbanização do país. (DEL PRIORE, 2017, p. 223)

Torna-se relevante ressaltar, no entanto, que a personagem de Maria Luísa nesta parte narrativa assume aspectos característicos desta mulher burguesa no universo familiar, que no Brasil moderno irá concentrar qualidades conservadoras e progressistas, no processo chamado de modernização da desigualdade por BESSE (1999). Nessa composição, mais do que se comportar de acordo ou em desacordo com as regras estabelecidas, Maria Luísa se posiciona diante delas e é através deste posicionamento que assume autoridade na esfera doméstica, o que corresponde a uma atitude não condicionada pela passividade simplesmente que se condensa na sua inflexibilidade na primeira parte do romance, assim evidenciada a partir de uma perspectiva irônica da narradora. Desta forma, na sua constituição, a personagem carrega também as contradições que recaem sobre essas mulheres em dado contexto, uma vez que ao mesmo tempo em que recusa a submissão às ordens de um marido, ainda assim, apresenta-se contra as possibilidades de certa autonomia feminina, manifestando-se segundo os padrões estabelecidos socialmente.

Através do contraste consigo teremos alusão a outros dois estereótipos femininos que aqui estarão presentes ainda, mas que, ao contrário de se 
demonstrarem como tomada de posição (a não passividade diante do contexto, ainda que deformada pelos limites sociais impostos), apenas se comportam de acordo com os estímulos sociais vigentes, correspondendo a uma atitude, de certa maneira, passiva e inconsciente na sua condição. São eles: 1. a mulher do século $\mathrm{XIX}$, que educada sob as leis do patriarcalismo oligárquico é obrigada a se submeter à figura do marido; 2. a mulher moderna deste início do século $X X$, cujo estereótipo é resumido nas revistas femininas da época com a predominância da futilidade como característica, que adquire certa autonomia pela independência econômica (aqui acarretada por uma de suas únicas vias: a viuvez $)^{8}$.

Equilibrando o seu posicionamento entre o antigo e o novo paradigma, ou pairando no trânsito de um para o outro, Maria Luísa dissocia-se das duas outras personagens femininas que apresentam similitudes com as conformações estereotipadas do antigo e do novo. Faz-se relevante ressaltar que, diferente de Lola e de D. Constância, Maria Luísa aparenta ter certa autonomia nesta primeira parte narrativa devido à autoridade de seus julgamentos, o que a narradora também delata, conforme veremos a seguir. Sendo assim, ela assume para si muitos dos comportamentos impostos socialmente a uma mulher de seu círculo e sua postura torna-se balizante de outras.

Assim sendo, a princípio, quando disposta em contraste com Lola, Maria Luísa apresenta sua versão mais conservadora. Eis então o primeiro contraste: enquanto o comportamento de Lola adere a este estereótipo da mulher viúva independente, sob possibilidade de gerir economicamente a sua vida, o que em última instância se configura como sendo, naquele contexto, uma liberdade possível para a mulher (ainda que com inúmeras restrições), o posicionamento de Maria Luísa será catalisado por um espectro conservador, que rejeita esta "liberdade" possível nos condicionantes de uma sociedade de ideologia patriarcal, submetendose a ela.

No contraste entre essas duas personagens, são apresentadas duas facetas que pairam sobre a vida da mulher de 1930 e que se configuram como uma contradição presente na sua condição: enquanto Lola representa certa liberdade restringida no que tange o seu poder de ação e trânsito, o que permite a ela escolher

\footnotetext{
${ }^{8}$ A partir dos anos 1920 , a viúva se torna emancipada para gerir os bens de sua família. No entanto, essa autonomia é perdida ao se casar novamente, passando o novo marido a executar o papel de gerenciador, inclusive tendo maior autoridade sobre a educação dos filhos do casamento anterior.
} 
por um relacionamento, por exemplo, que não respeita os padrões sociais impostos, Maria Luísa se ancora em padrões tradicionais condicionantes do comportamento feminino, submetendo Lola aos seus ajuizamentos transpassados por eles, para imputar à cunhada o papel de vulnerável ou ainda legitimar o estigma social que a coloca como desonesta ao fazer uso de sua "liberdade": "uma mulher de quem se fala era uma mulher com quem não se fala" (PEREIRA, 2006, p. 14). Assim sendo, aqui, contrastada com Lola, Maria Luísa assume sua vertente mais conservadora, que a voz narrativa deixa entrever com certa ironia angariada pelo exagero, quando descreve a conversa entre as duas:

Muito graciosa, muito loira, muito redondinha, com um ar de boneca, Lola destilava perfume e frivolidade. Destoava na sala de Maria Luísa. Mas nem parecia percebê-lo. Saltitante e risonha, tinha gestos faceiros, dizia coisas ligeiras. E criava seu ambiente.

(...)

As palavras vaporosas de Lola solidificavam-se ao baterem na zona pétrea da cunhada, que Ihes buscava um sentido preciso. E se reduziam a informes pedações de gelo, como uma nuvem se desfaz em granizo. (PEREIRA, 2006, p. 17)

A autoridade de Maria Luísa, posta desta maneira, contrasta com a faceirice de Lola, como podemos observar. Nota-se aqui outro aspecto fundamental do novo papel da mulher diante dos paradigmas que se vão formando. Ante o ensejo de manutenção da ordem em relação à família que as contestações de mulheres em busca de maior liberdade ameaçavam no período era necessário a vigilância. Se nesta sociedade que se caracteriza pelos ideais burgueses que determinam novos condicionantes já não é mais cabível o controle escancaradamente violento do patriarca sobre a mulher, aprisionando-a em casa, o que reverbera num afrouxamento deste tipo de vigilância, haverá uma educação da mulher moderna para o autocontrole e controle alheio. As mulheres bem-comportadas com bases em etiquetas que dão novo viés à sociedade burguesa irão vigiar umas às outras. Função que Maria Luísa assume com relação à Lola nas desconfianças que manifesta para com a cunhada, ainda mais que a figura masculina de Artur, como nos evidencia a narradora. É ela a contestar a liberdade de Lola, afinal, ainda que o que se tinha eram boatos sobre a cunhada, "repugnavam-Ihe as relações, mesmo as 
de mera formalidade com uma pessoa de respeitabilidade duvidosa" (PEREIRA, 2006, p. 18). Em relação à Lola, portanto, Maria Luísa assume a subordinação às regras sociais, enquanto o papel de insubordinação fica com a cunhada (ainda que esta insubordine-se, aparentemente, mais por alienação do que por confronto).

No entanto, se com Lola Maria Luísa se traveste do severo conservadorismo sob o resguardo da reputação, subordinando-se assim às ordens de controle à vida da mulher, com sua mãe ela irá representar exatamente o oposto disso. Em contraste com D. Constância, Maria Luísa é uma esposa que desafia os padrões de outrora, ao criticar o marido abertamente, sem ceder às suas ordens, o que é possibilitado também pela inferioridade cultural e intelectual que afere a ele, quando posto diante de outros homens que lhe são referenciais, principalmente no que tange a questão de origem de classe, uma vez que seu marido é um novo burguês em contraste com sua família de lustro aristocrático:

Maria Luísa sentou-se na cama, onde ainda dormitava, e o fitou longamente, com a fixidez um pouco espantada de quem acaba de acordar.

Assim colorido e nédio, a andar pelo quarto em mangas de camisa, era um perfeito português. Português de baixa classe, como o tinham sido seus antepassados.

- Papai tem razão, pensou ela, é indelével o estigma do sangue...

$\mathrm{E}$, por associação de ideias, com certeza, passou-lhe pela mente a fisionomia serena e fina do próprio bisavô, o do busto. (PEREIRA, 2006, p. 53)

Enquanto D. Constância se devota em obediência aos caprichos de Sr. Lemos (pai de Maria Luísa), em uma atitude de resignação e, portanto, submissa, Maria Luísa desdenha de certas atitudes de Artur. Aqui temos configurado portanto dois tipos distintos de atitudes relacionadas à vida conjugal: de um lado a submissão 
de D. Constância, do outro certa ${ }^{9}$ insubmissão de Maria Luísa, estabelecendo assim os polos insubmissão/submissão no ambiente doméstico do núcleo familiar, em contraste com o subordinação/insubordinação no ambiente social. Vejamos a reação de D. Constância perante a atitude de Maria Luísa:

Nunca se pudera habituar à rispidez com que a filha tratava o genro. Que fosse assim com ela, com os filhos, com o pai mesmo, vá lá, era o seu gênio, e possuía outras qualidades que contrabalançavam fartamente esse pequeno defeito.

Mas o marido... (PEREIRA, 2006, p. 42)

Maria Luísa é dimensionada até aqui nessa configuração entre tensões de opostos com relação às outras figuras femininas do romance. Diante da vida social, apresenta-se subordinada, enquanto que na vida doméstica assume caráter insubmisso. Na primeira metade da narrativa temos contato com esses aspectos que parecem paradoxais no entreposto de comportamentos conservadores e avançados que a caracterizam. A partir da segunda metade do romance, entretanto, o que antes parecia divisível - e a separava das outras - fará parte de um todo complexo que emerge na narrativa através do discurso indireto livre, invertendo a ordem desse polo (subordinação/insubordinação social $X$ insubmissão/submissão doméstica) antitético e a impelindo para o polo sintético, que tende a se centralizar na submissão doméstica enquanto pode incorrer em alguma insubordinação social. Essa mudança de perspectiva será inaugurada desde um desentendimento com Artur, que a leva a perceber a autoridade do marido, e se consolidará no seu encontro com Flávio que resulta no adultério responsável por lhe arrancar da redoma do casamento ideal na qual se conservara até então, culminando numa espécie de ruptura que a fará questionar, principalmente, sua condição de mulher sob o alvará do casamento.

\footnotetext{
${ }^{9}$ Ressaltamos "certa", porque ainda que Maria Luísa se imponha neste momento à autoridade de Artur, ela não tem e nem terá qualquer autonomia diante do marido. No entanto, apresenta-se aqui em contestação a essa sociedade marital e é o aspecto de contraste com D. Constância. Sobre isso, cf. Del Priore: "(...) a esposa virtuosa era aclamada e cercada por comando morais. Prescreveu-se para ela a complacência e bondade, para prever, satisfazer e até adivinhar os desejos do marido; dedicação para compartilhar abnegadamente com ele os deveres que encerrava o casamento; paciência para aceitar suas fraquezas de caráter" (DEL PRIORE, 2015, p. 254). É perceptível neste apontamento como Maria Luísa destoa deste lugar exigido às mulheres.
} 
Chamamos de ruptura por duas razões: primeiro porque há um corte temporal na narrativa, que vinha se apresentando de forma cronológica e linear - a primeira parte se fecha com o encontro entre Maria Luísa e Flávio, a segunda se abre com Maria Luísa questionando a hipocrisia das relações que se faziam ao redor de si depois de sua experiência emocional e sexual com Flávio. Segundo porque há uma guinada na voz narrativa: se antes havia a presença significativa de diálogos organizados pelo discurso direto permeados por insistentes comentários narrativos, que validavam uma avaliação da narradora, agora ocorre um domínio narrativo do discurso indireto livre outorgado à Maria Luísa. Portanto, temos duas novas proposições que determinam essa virada narrativa.

Antes, no entanto, de darmos continuidade às explanações sobre o que culmina nessa virada, é importante elucidarmos um elemento que irá se transpor à vida de Maria Luísa, senão influindo diretamente, pelo menos a cingindo de forma indireta: a crise financeira que afeta de maneira bastante pungente a história de outras personagens que circundam a vida da protagonista, configurando assim determinado cenário. A crise ${ }^{10}$ é exposta tal qual aos olhos de Maria Luísa que a ela não dá maiores atenções a não ser através daqueles que a cercam. Sequer a narradora nos informa de qual crise se trata, suas causas e consequências, uma vez que essa só importa à medida que interfere na vida privada da protagonista. Se sua atenção não irá confrontar a crise, a crise irá causar desdobramentos em sua vida. São três, pelo menos, os elementos que possibilitam esses desdobramentos: Artur, que não é significativamente afetado, mas que é obrigado a se ausentar das férias em família; Lola, que vai à falência e perde, portanto, sua relativa autonomia; e Flávio, que, afetado economicamente, vê-se obrigado a voltar de suas incursões pela Europa:

A crise financeira poupou Artur; mas teve, na sua família, uma consequência gravíssima.

Por morte do marido, Lola recebera uma boa herança em apólice: o sogro, então ainda vivo, pensava que dinheiro de viúva e de menor não podia correr os riscos de uma empresa comercial, mesmo

\footnotetext{
${ }^{10}$ Supomos se tratar aqui das sérias consequências da crise de 1929 que, no Brasil, afetam a economia e a política ocasionando a queda da oligarquia cafeeira de São Paulo, o que possibilitou a ascensão de Getúlio Vargas ao poder.
} 
segura com a sua. Quando este veio a falecer, livre de uma tutela que de si pra si qualificava de tacanha, ela procurou obter melhores juros para o seu capital e para o da filha.

A conselho do marido de uma das irmãs, colocou-os, acrescidos ainda pelo legado do velho negociante, numa firma de bom renome, e de lucros tentadores. Artur, instigado por Maria Luísa, protestou, mas em vão.

E agora, essa casa acabava de quebrar ruidosamente, e prevenira a cunhada; mas já era tarde para salvar os seus bens. (PEREIRA, 2006, p. 34)

Sabemos que a ausência de Artur e a presença de Flávio irá dar caldo para o desenrolar do adultério. A relação de Maria Luísa com Lola se transforma a partir deste ponto, porque, por uma parte da narrativa logo após o empobrecimento de Lola, Maria Luísa será uma espécie de tutora da cunhada, a ponto desta se confundir com aquela, no que Luís Bueno chamou de "duplo espelhado" (2006, p. 305). Esse é o primeiro movimento na narrativa que permite a percepção de certa identificação entre mulheres: a cunhada, viúva e empobrecida, afastada daquele que julgavam ser seu amante (porque este precisou viajar à Europa com o irmão doente) vê-se completamente desolada e Maria Luísa, ainda que tenha antes questionado o comportamento de Lola, aproxima-se dela para ajudá-la a se reerguer, com intuito óbvio de modificar sua postura. Ou ainda, segundo Bueno, a narrativa se encaminha aqui indicando que "o modo de ser de Maria Luísa triunfará" (2006, p. 306).

Evidentemente, o que fica demarcado aqui é a rígida personalidade de Maria Luísa incidindo sobre a cunhada, que em suas mãos continuava tão vulnerável como o era na perspectiva de Maria Luísa antes, e a narradora expõe: "Um pouco de argila dócil, que Maria Luísa moldou" (PEREIRA, 2006, p. 37), o que remete para algo artificial que, rapidamente, sofrerá modificações (a saber, a volta do companheiro de Lola). No entanto, apesar da identificação temporária de Lola com Maria Luísa, aportamos, pela primeira vez, num universo não dual (de oposição) que vinha sendo, até então, estabelecido pelo contraste entre Maria Luísa e outras mulheres discutido anteriormente e que nos interessa observar. A crise, portanto, parece possibilitar um novo posicionamento das personagens femininas, 
transfigurando a ideia de oposto. Ainda assim, concordamos com Bueno em que esse artifício dá indícios que o modo de ser de Maria Luísa irá triunfar, qual seja, a subordinação às exigências sociais ganha destaque uma vez que a independência econômica da figura feminina se dissipa. Resta assim a Lola seguir o modelo espectrado em Maria Luísa.

Ressaltamos fundamentalmente que em Maria Luísa segue este espectro de autoridade que só sofrerá modificações mais assertivas, de fato, depois do adultério, que lhe arranca do espaço da esposa modelo diante de uma sociedade de ideologia patriarcal e a faz se identificar com as outras, enfraquecendo a movimentação em fazer com que as outras se identificassem consigo. Assim teremos então uma nova toada narrativa que ficará caracterizada também através daquilo que não é nela colocado em detalhes, caso relevante no que tange seu encontro com Flávio. Amigo de Artur, Flávio surge na narrativa como um bon vivant que se vê obrigado a voltar da Europa para o Rio de Janeiro quando a crise financeira toca os negócios de sua família que lhe garantiam a boa vida. Depois de uma desavença, deflagrada pela inquietação em Artur que a vinda de Flávio estimulou, partem, ele e Maria Luísa, com os dois filhos, para férias no campo. Obrigado a voltar às pressas para a capital carioca (mais uma vez aqui a crise), Artur convida Flávio para seguir com ele para o local onde a família passava as férias. Entretanto, impedido de voltar pelo trabalho, Flávio parte para o encontro de Maria Luísa sem Artur.

É importante notarmos que o início do que chamamos de virada narrativa começa a se apresentar logo depois da desavença entre Maria Luísa e Artur, e que somos levados a entender que é ocasionada pela disputa interna que se estipula nele através da projeção das figuras de Flávio (a referência de antes) e Maria Luísa (a referência do agora). A mudança repentina no comportamento de Artur, que se demonstra autoritário diante de um fato corriqueiro, desperta imediatamente em Maria Luísa dúvidas para com o seu casamento, o que corrobora de maneira significativa uma nova perspectiva a ser elaborada a partir de então:

Pela primeira vez, desde que se casara, sentiu que ela e Artur não eram as partes inseparáveis do mesmo todo. Que podiam existir um sem o outro - pois, um ao lado do outro, haviam vivido separados. E desconhecidos. 
Até então entendera o casamento como uma unificação completa. $\mathrm{E}$ não só o seu. Um casal infeliz seria, para ela, um organismo doente, mas um organismo. Ainda que mal, só poderia viver completo.

$\mathrm{E}$, de chofre, o mundo ignorado descoberto no companheiro de tantos anos the veio trazer uma sensação horrível de dualidade. E da solidão. Era como se the houvessem arrancado uma parte dela mesma. (PEREIRA, 2006, p. 51)

A violência da reação do marido ali, antes mesmo da viagem, empurra Maria Luísa para fora de sua vida tão sistematicamente organizada. Nota-se que a experiência da protagonista com relação ao marido muda a partir do momento em que ele assume a "dualidade", ou seja, a partir do momento em que nele pairam também os arquétipos patriarcais de marido tradicional dos quais ela pensava estar protegida em sua autoridade. Se há um dever que Maria Luísa não cumpre até então e que contradiz as exigências sociais prospectadas no modelo ideal projetado em si é aquele que resplandece em D. Constância, como já mencionamos, da submissão ao marido. Isso se justifica porque até aqui Artur assumira a condição daquilo que D'Icao chama de "novo patriarca"11 (2017, p. 239). A partir do momento em que nele fica projetada a voz de autoridade, através do discurso autoritário, há uma quebra de expectativa dela com relação ao casamento e os valores do casamento entrarão em conflito em sua perspectiva.

Isso irá ser intensificado quando a personagem é imersa na sua solidão de férias no campo. Há uma modificação do espaço narrativo, que se transfere da zona urbana para a campestre, culminando num relaxamento de suas únicas atividades esposa e mãe -, o que produz em si o tédio reflexivo. Assim, finalmente Maria Luísa terá tempo para se voltar para si mesma. Essa experiência traz angústia, uma vez que também viabiliza uma mudança de perspectiva na medida em que a projeta para fora do solo de sua rigidez e a coloca às voltas com a ausência de sua própria identidade - identidade esta que, como fica claro através do discurso indireto livre que se segue, não diz respeito ao que enxerga sobre si, mas sim àquilo que para si

\footnotetext{
11 "O mundo familiar burguês é um mundo em si mesmo, não tem grandes laços com a sociedade inclusive; é autossuficiente, socialmente falando, e isolado. Os membros da família não conversam senão sobre coisas banais e sobre a educação dos filhos. O chefe da casa, o novo patriarca, o patriarca burguês, investido de doçura e compreensão, determina todas as coisas que devem acontecer" (D'Icao, 2017, p. 239).
} 
é socialmente atribuído. Essa movimentação torna clara a sua insatisfação com a realidade que a cerca, como a narradora nos evidencia em mais um de seus comentários avaliativos:

Uma pessoa que tem a vida toda regrada e se compraz nesse método; que sabe, ao acordar, todos os passos a dar e os horários a cumprir, anda metida numa engrenagem à qual nem sonha fugir. $E$ que a governa. A sucessão ininterrupta de horas marcadas e obrigações a satisfazer absorve-lhe, via de regra, toda a atenção. $\mathrm{E}$ tira-Ihe o ensejo de examinar a existência de um ponto de vista mais alto. O plano geral, se alguma vez existiu, fica submerso pela caudal das minúcias. E da boa execução destas decorre uma impressão de felicidade talvez superficial, mas nem por isso menos eficiente.

Vai anestesiando essa porção mais exigente de nós mesmos, essa parte instintiva, profunda, tumultuária, que anseia por uma satisfação completa - e não sabe onde encontra-la.

Tirai, porém, a um indivíduo nessas condições os andaimes protetores dos hábitos. Logo se debaterá no vazio, e ruirá por terra todo o edifício de sua tranquilidade. (PEREIRA, 2006, p. 54-55)

O enredo encaminha para essa transição que se materializa em seu encontro com Flávio. Torna-se imprescindível que notemos que os detalhes da história com Flávio não interessam à perspectiva narrativa, a ponto de serem suprimidos dessa, que tem um salto temporal bastante significativo quando comparado a linearidade temporal anterior. Tomamos ciência apenas dos primeiros contatos entre os dois, o estágio de encantamento que se vai tecendo e a seguir a chegada de Artur, depois de uma longa temporada no Rio de Janeiro. No entanto, as modificações provocadas por esse encontro ficam expostas em breves passagens:

A sensação de ofuscamento, de ter sido bruscamente arremessada das trevas para a luz não abandonou mais Maria Luísa.

Tinha a impressão vertiginosa de estar sendo arrebatada por um espaço de dimensões infinitas, em que se perdiam todos os seus pontos de referência. 
Flávio a interrogava, com uma insistência amável e dominadora, contra a qual se via sem defesa. Eram perguntas incisivas, diretas, que a obrigavam a olhar para dentro de si. Para regiões que nunca explorara.

E acordavam nela uma mulher desconhecida, revoltada contra a mesmice da vida, vibrante de loucas aspirações. (PEREIRA, 2006, p. $72 ; 73)$

E é a partir da ausência dos "seus pontos de referência" que passa a ser projetado como uno o que antes parecia divisível. Através da experiência do adultério, Maria Luísa passa a rever a sua postura, mas, principalmente, a rever e a questionar as relações que se estabelecem ao redor de si e que lhe oprimem, empurrando-a para determinada postura. É notável que os procedimentos em Maria Luísa com relação ao adultério seguem alguns dos padrões relacionados ao romance de adultério europeu do final do século XIX, como aponta Maria Teresa Oliveira:

A mulher lança-se nos braços de um outro homem por motivos múltiplos, que vão do tédio à ânsia de aventuras e ao prazer em contrariar a moral instituída, mas dos quais está quase sempre ausente o amor enquanto força para além do Bem e do Mal. Aliás, a concentração na figura feminina e no seu destino, que é própria do romance realista de adultério do século XIX, faz diminuir o interesse pelos outros dois vértices do triângulo amoroso, que surgem tendencialmente funcionalizados. $O$ amante ganha frequentemente traços de sedutor demoníaco e é comum o seu desinteresse pela mulher, que assim se vê confinada à situação de seduzida e abandonada. Este abandono é, então, considerado como parte integrante da punição devida por uma culpa que as protagonistas destes romances, embora de maneiras muito díspares, não deixam de assumir. As questões à volta da sua situação e de sua culpa, a que as heroínas adúlteras não conseguem eximir-se, são outro dos focos de interesse generalizados nos romances de adultério do século XIX. (...) é frequente termos no centro da narração não a vingança do marido mas o seu efeito, real ou imaginário, sobre a 
mulher. (...) A punição não deixa, todavia, de ser eficaz: o destino da adúltera é geralmente a morte. Privada do seu papel na sociedade, situação a que se alia a perda de identidade, a mulher mata-se ou deixa-se morrer. $\mathrm{O}$ seu destino funesto tem causas primordialmente sociais. (OLIVEIRA, 2000, p. 47)

No entanto, embora o foco narrativo seja voltando realmente para a heroína adúltera a partir de agora, o seu destino não corresponde à fatalidade típica desses romances. Maria Luísa inicia seu processo de questionamento acerca de tudo que antes Ihe parecia ordenado e questiona, dessa forma, a prisão que lhe roga a vida em família. Nesse sentido, não reage mais às angústias da mãe e tampouco opera crítica com relação à Lola, ao contrário, volta-se a questionar as hipocrisias das relações sociais as quais as mulheres estão submetidas. Parece-nos, então, que em Maria Luísa, da segunda parte do romance em diante, concentram-se todos os polos, antes contrapostos, que agora lhe permitem transitar reflexivamente entre subordinação, insubordinação na vida social e insubmissão e submissão na vida doméstica, destacando a complexidade que atua ante o antigo e novo que se estabelecem aqui não mais como contraditórios, mas como complementares e configuram, dialeticamente, o lugar social desta mulher.

O discurso indireto livre destaca-se então como recurso na condução narrativa (caso que iremos analisar em breve, ao nos centrarmos na narradora), que assim caracteriza esse romance na seara dos romances intimistas de 1930. Passa a ser preponderante a reflexão de Maria Luísa no lugar da narradora, o que resulta numa confluência entre essas vozes, revelando o narrar que se constitui através do compartilhamento da impressão da experiência social da mulher. É possível notar a diminuição significativa de diálogos. A narradora exerce onisciência ainda com relação a outras personagens do romance, mas é no pensamento de Maria Luíza que se fixa. E o que surge na narrativa é uma Maria Luísa questionadora, frustrada, sem energia para se manter tal qual era antes, uma Maria Luísa que quebra o "silogismo": tudo o que antes parecia estrutural em sua personalidade, condicionada pelas funções de mãe e esposa, entra em xeque.

O início de $A$ Montanha (parte II do romance) que representa essa virada narrativa, portanto, é demarcado formalmente por dois aspectos, aqui já descritos: 1. o corte em partes ( I e II) da narrativa, indicando que algo se altera; 2. o corte 
temporal, tal qual não se tinha dado anteriormente (passamos do início de março para junho: "um céu de noite de São João" - p. 77). Esses dois aspectos projetam a leitora e o leitor imediatamente para novas circunstâncias e temos contato, de fato, já na página inaugural desta parte, com as incertezas que vão transversar esse novo momento narrativo, a começar com certa rejeição de Maria Luíza à proximidade do núcleo familiar, no qual antes estava projetava sua identidade ${ }^{12}$ :

Debruçada à janela, Maria Luísa olhava a cena, distraidamente. Estava só. O marido fora com os filhos à casa de um amigo, onde havia festa para o Santo, festa à antiga, com fogueira e batata assada.

Ela pretextara uma dor de cabeça para não ir. Repelira irritada as insistências de Artur e dos meninos. (PEREIRA, 2006, p. 77-78)

Além desses aspectos, é possível que notemos uma modificação na organização paragrafal, composta agora por parágrafos muito curtos que remetem, dessa maneira, ao dinâmico fluxo de pensamento de Maria Luísa, como podemos observar nas páginas deste primeiro capítulo da segunda parte do romance. Assim sendo, parece fundirem-se aqui a narradora e a protagonista, levando-nos à necessidade de nos voltarmos, agora, para a configuração da voz narrativa.

\section{Narradora distante: entre a ironia e o comentário}

$\mathrm{Na}$ primeira parte da narrativa, tomamos contato com uma narradora que observa Maria Luísa através da aproximação de diversas outras personagens, com o recurso da onisciência, numa perspectiva distanciada, como apontamos. E se na configuração de Maria Luísa se apresenta uma ruptura que determinará mudanças significativas na personagem da primeira para a segunda parte do romance, como procuramos destacar nas páginas anteriores, o mesmo é observável na estruturação da voz narrativa. Dois elementos sofrem acentuado enfraquecimento que diagnosticam esse sentido: a ironia e os comentários. Temos, então, que

\footnotetext{
${ }^{12}$ Consideremos aqui identidade a anterior identificação da protagonista com suas funções de mãe e esposa, que sobressaem na ação narrativa.
} 
enquanto a primeira parte do romance é apresentada por uma narradora que utiliza amplamente o recurso da ironia, mantendo de Maria Luísa uma perspectiva distante, porque contestatória, na segunda parte essa postura cede lugar ao pensamento angustiado e melancólico da personagem que a narradora acompanha abrindo mão do tom irônico assumido anteriormente, numa perspectiva desta vez próxima através do discurso indireto livre. Da mesma maneira, enquanto a primeira parte do romance é demarcada fortemente por frequentes comentários da narradora, na segunda parte narrativa esses comentários praticamente desaparecem. Esses dois elementos juntos contribuem para que a narradora da primeira parte do romance seja, também ela, uma personagem a ser observada pela leitora ou leitor, devido à sua evidente intromissão narrativa. Enquanto que posteriormente seu aspecto de personagem se diluirá, confluindo com Maria Luísa.

\section{A ironia}

É sobre Maria Luísa, principalmente, que recairá a crítica irônica da voz narrativa, a partir do espectro do casamento no qual está condicionada a protagonista, que tece o fio que envolve Maria Luísa às outras e aos outros. A personagem é estruturada aqui a partir da instituição família, e todas as suas ações estão acondicionadas nela. Maria Luísa é o casamento, julga através do casamento, torna-se modelo social a partir do casamento, o que é revelado por uma narradora desconfiada. Constitui-se, assim, como esposa e mãe e nessa composição paira toda sua reflexão, que, individualizada e isolada, não possibilita uma consciência coletiva de gênero. Dessa forma, a perfeição de Maria Luísa nesse contexto desagrada a narradora, que evidencia seu incômodo com o recurso irônico.

Linda Hutcheon, em seu estudo sobre a ironia, aponta que essa perpassa por uma estratégia discursiva e uma política, contestando certos discursos dominantes a partir da apropriação do mesmo discurso. Neste sentido, o conceito toma um "contra-discurso", ao utilizar "suportes de teorias de oposição que atacam hierarquias", tornando-se uma espécie de "paixão negativa", "um modo de combate" "para deslocar e aniquilar uma representação dominante do mundo" (Hutcheon, 2000 , p. 54). A teórica, no tocante à perspectiva feminista acerca da ironia, contextualiza-nos: 
Debates semelhantes ocorreram em círculos feministas, onde a suspeita da instabilidade da ironia é frequentemente oposta pela consciência do poder que existe em sua potência desestabilizadora. Às vezes esse poder é diretamente utilizado para fins de oposição e crítica; às vezes ele é mais uma tentativa indireta de "trabalhar" contradições ideológicas e não deixá-las se resolver em dogmas coerentes e, assim, potencialmente opressivos. (Hutcheon, 2000, p. 56)

A partir do momento em que assumimos que a voz narrativa do romance é de uma mulher, torna-se mais evidente que esse discurso elaborará, ainda que impregnado em diversos momentos por certa ideologia patriarcal, da qual esta narradora em seu contexto também não escapa, um evidente movimento que refuta a ideologia opressora. Parece-nos que a maior evidência disso se apresentará quando contraposta à própria Maria Luísa configurada através de meandros desta ideologia na primeira parte da narrativa, a quem aponta como antítese a cada um dos contrastes apresentados. Com o distanciamento que assume da protagonista, imputa a esta uma superficialidade que repercute em desconfiança a seu comportamento, sempre reforçada pela vertente irônica.

$\mathrm{Na}$ primeira parte, portanto, a narradora induz a leitura oblíqua de Maria Luísa nos fazendo compartilhar a sua perspectiva negativa em relação à personagem aqui posta como modelo ideal, socialmente representado, de esposa e mãe. Assim delineado seu posicionamento, temos que ainda que a protagonista direcione seu comportamento na busca por se constituir como tal modelo, a narradora irá desestabilizar esse posicionamento ao circundá-lo de objeções. Não importa qual seja o lado assumido por Maria Luísa, se mais progressista ou mais conservador, em seu estatuto de mulher. Se Maria Luísa é mais conservadora, como quando colocada em contraposição à Lola, há ironia sobre ela. A mesma ironia que haverá quando se porta de maneira mais progressista com D. Constância. Maria Luísa assim não representa nem os ideais da mulher moderna mais livre socialmente; nem aquilo que se tinha em termos de modelo tradicional, submissa à autoridade de um marido, mas nos parece mais uma tentativa de conciliação entre ambas, o que assente uma contradição, que será contestada. Como sua rigidez é enfatizada o tempo todo pela voz narrativa, essa contradição, 
que aparentemente se escamotearia em suas assertivas, é evidenciada pelo posicionamento da narradora.

Logo no início da narrativa, portanto, temos dimensionado este posicionamento:

Algumas pessoas virtuosas criam em torno de si um estranho ambiente. Possuem o dom incômodo de fazer pensar menos nas suas qualidades do que nos defeitos alheios.

Talvez seja tão forte a sua influência sobre o meio, que consigam estabilizá-lo ao nível altíssimo dos seus predicados...

E a inferioridade dos outros forma como que escavações e depressões, a destoarem na harmonia desses planaltos morais. (PEREIRA, 2006, p. 15)

À tentativa de Maria Luísa de se prostrar como modelo ideal de esposa e mãe, a narradora contrapõe-se, criando uma espécie de jogo antitético que desvenda o paradoxo e compõe a complexidade que finalmente se afirmará na figura da protagonista a partir da segunda parte do romance. Tal jogo irá caracterizar a personagem desde o início da narrativa, como buscamos apontar anteriormente, principalmente através de outras personagens mulheres do romance, conformando sua personalidade acessada apenas superficialmente devido à posição distanciada e crítica da narradora. Dessa maneira, a narradora contrapõe Maria Luísa à D. Constância e à Lola, mais enfaticamente, caracterizando a personagem em seus aspectos psicológicos e sociais a partir do maniqueísmo, através do qual a protagonista irá sempre assumir o antagônico mediante cada uma delas. Essas comparações são transpassadas pelo espectro do casamento e Maria Luísa assim vai se configurando como o modelo ideal de esposa, mãe e mulher na sociedade dos inícios dos anos 1930, a partir do ideal patriarcal que nesta fase no Brasil se transformava, mantendo, porém, uma ordem anterior, como Susan Besse aponta:

Durante a década de 1920 e 1930, em busca de esteios para a ordem, a racionalidade, a "evolução" e o "progresso", a comunidade profissional e intelectual urbana do Brasil lutava por "regenerar" a família e elevá-la (com as mulheres em seu centro) como instituição 
social primordial e essencial, capaz de promover a modernização econômica preservando a ordem social. (BESSE, 1999, p. 64)

A métrica é organizada pela narradora de maneira que Maria Luísa é exposta aparentemente por essa modernização que preserva a ordem social, na sua composição de subordinação social e insubmissão doméstica, que vislumbra contradições. Sua personalidade, através da narradora, sobrepõe-se às outras em autoridade: "Maria Luísa era um silogismo vivo. E insofismável" (p. 17). Mas, se no desenrolar do enredo somos postos a observar que esta premissa não é verdadeira, uma vez que o silogismo insofismável tornar-se-á um sofisma difuso a partir do abalo que sofre a manutenção do modelo, também evidenciado fica o tom irônico assumido pela voz narrativa. E justamente através dessa ironia que é forjada uma autoridade no texto que se fará maior do que a de Maria Luísa: a da própria voz narrativa.

O espectro do casamento é que tece o fio que envolve Maria Luísa ao outro (seu marido) e às outras e a ironia tem aqui a função de apontar em Maria Luísa uma perfeição incômoda. Por dedução, é possível ler nas entrelinhas desta postura narrativa que Maria Luísa não é crível, ou seja, aquele modelo de mulher não pode ser real exceto quando constituído superficialmente. Podemos notar ainda mais claramente essa crítica da narradora à Maria Luísa através de seus comentários digressivos em passagens como:

O castigo de quem vive exclusivamente de fora, e para fora, essa impossibilidade de poder parar, de se fechar um pouco dentro de si, para descansar. O eu torna-se quase uma carga inútil, o eu elevado, bem entendido. Uma espécie de casa de caramujo - onde o caramujo não se pudesse abrigar. Um peso morto que se carrega às costas. (PEREIRA, 2006, p. 55)

Apesar dessa atuação singular com Maria Luísa, a ironia da narradora também é franqueada às outras personagens, apresentando suas discordâncias com cada uma delas e alavancando um contínuo aspecto crítico àquilo que é narrado. Transparece assim o mesmo incômodo, projetando para além de Maria Luísa as fissuras na constituição de determinado contexto, o que pode ser observado desde a inauguração da narrativa, a começar por Artur. Enquanto Maria 
Luísa teme receber em sua casa uma mulher de má reputação, Artur não se importa, desde que as aparências sejam mantidas. Sobre isso, diz a narradora: "As senhoras são mais exigentes - sobretudo quando se trata de honestidade feminina" (p. 14).

As senhoras são mais exigentes evidentemente porque mais cobradas, tanto quanto fica claro em toda a postura enfatizada pela hipérbole discursiva da narradora com relação ao juízo de Artur sobre a esposa, logo a seguir:

Uma mulher como poucas. Admirável. Perfeita. Perfeitíssima. Boa filha, esposa exemplar, mãe cuidadosa, excelente dona de casa. Em tudo, cumpria rigorosamente as suas obrigações. Das minúcias do seu interior ao mais grave problema da vida do casal, tudo merecia a sua atenção, tudo resolvia com critério e acerto. Até em negócios Artur continuava o comércio de fazendas em grosso que the legara o pai - era de bom conselho. Socialmente, soubera criar uma situação de que se envaidecia o marido. Não que andasse em festas e bailes - não era disso. Cultivava algumas relações, poucas, mas escolhidas, escolhidíssimas. Como nunca as poderia ter o Artur Pires, da firma Pires \& Sá, cujo fundador, o seu avô, desembarcara no Rio de tamancos e jalequinho de veludo rapado.

Uma mulher do dever, em suma.

E Artur não the exagerava os méritos. Julgava-a sem entusiasmos, que não Ihos permitiria o contato diário. (PEREIRA, 2006, p. 14)

O recurso irônico é assumido aqui através do caráter hiperbólico para classificar as atitudes perfeitas de Maria Luísa em contraposição ao não entusiasmo do marido. Ainda no compêndio das três primeiras páginas de abertura desta parte, deparamo-nos com outra passagem que nos vem a esclarecer este posicionamento contrário a Artur, na banalização de seu comportamento adúltero:

Artur sentia tanto mais o rebaixamento que sofria com a austeridade da mulher, quanto tinha, a roê-lo, a lembrança de algumas infidelidades.

Coisas ligeiras, aventuras sem consequência. Mas para quem tinha uma companheira dessas... (PEREIRA, 2006, p. 15) 
Se na leitura inaugural do romance paira alguma dúvida sobre a entonação irônica do trecho acima, essa dúvida se dissipa ao longo narrativa. Ora, se é justamente o adultério de Maria Luísa que acarretará uma guinada na personagem, trazendo para ponto nevrálgico do romance o questionamento à ordem posta nos papéis sociais desempenhados, principalmente no que tange à instituição casamento, obviamente revelada assim, com lampejos de irrelevância, a infidelidade de Artur corrobora um posicionamento irônico que incita uma crítica comparativa entre ele e o que irá ocorrer com sua esposa. A narradora nos deixa entrever que se para este algumas infidelidades (destaca-se o plural) foram aventuras ligeiras e sem consequências (que só o roem porque a companheira é austera), para aquela uma única infidelidade terá papel avassalador, no sentindo de colocar em xeque o que se acredita ser. Arquitetado dessa maneira, o ponto de vista aqui aponta para um aspecto social que estrutura a relação de Maria Luísa e Artur, qual seja os privilégios deste diante de situações semelhantes daquela, mas que a narradora não vê com bons olhos.

Sobre o adultério, Del Priore nos afirma que havia uma diferença significativa entre o masculino e o feminino ${ }^{13}$. Enquanto este era condenado, aquele era incentivado como "livre exercício da sexualidade" (2017, p. 265). Ainda sobre essa lógica, a narradora parece criticar aqui um aspecto da transposição dos valores da família patriarcal tradicional para a família burguesa. Segundo Angela Mendes de Almeida, aquela se tratava de uma família poligâmica, cuja ética incentivava ao homem branco relações sexuais ativas - todas "as possíveis e desejáveis"enquanto para a mulher branca restava a obrigação de castidade e, depois, de fidelidade (1987, p. 55). Artur mantém, sob a ótica da narrativa, esse comportamento, ao normatizar para si essas "aventuras sem consequência", em contraposição às resultantes deste mesmo comportamento em Maria Luísa, ao que a narradora, revelando, opõe-se.

Se é com ironia que a voz narrativa paira sobre o comportamento de Artur, não será com menos ironia, nessa primeira parte narrativa, que a narradora se

${ }^{13}$ Segundo Mary Del Priore: "Adultério masculino era sinônimo de problema de foro íntimo; o feminino de crime e escândalo. (...) Se, para os homens, o livre exercício da sexualidade era incentivado, entre as mulheres, era condenado. A "pureza" era tudo" (DEL PRIORE, 2015, p. 265). Essa normativa é evidente na diferenciação entre esses dois tipos de adultérios presentes na narrativa. 
posicionará diante da própria Maria Luísa na rigidez com que conjectura, em aspecto parecido com o mencionado acima, a relação de Lola com seu marido. Para tanto, a narradora intercepta seus julgamentos sobre Lola:

Entretanto, a despeito das suas más previsões, pareciam haver sido felizes, e Lola chorara corretamente o marido quando, havia três anos, um acidente de automóvel o matara.

Mas talvez o rapaz houvesse referido à mulher a oposição feita por Maria Luísa ao seu enlace. Ou seria esta que nunca se resignara a não ter razão. O fato é que suas relações haviam sido sempre cheias de reserva.

Para além de se posicionar ironicamente tanto com relação às infidelidades de Artur, como em relação às desconfianças de Maria Luísa à fidelidade de Lola ao marido, apontando em um a desfaçatez e na outra a rigidez, também haverá ironia no que diz respeito à figura de boneca que Lola representará:

Muito graciosa, muito loira, muito redondinha, com ar de boneca, Lola destilava perfume e frivolidade. Destoava na sala de Maria Luísa. Mas nem parecia percebê-lo. Saltitante e risonha, tinha gestos faceiros, dizia coisas ligeiras.

E criava seu ambiente. (PEREIRA, 2006, p. 17)

À resignação submissa de D. Constança, que assume perante Artur o comportamento que estimava ser o de Maria Luísa, a narradora revela alguma dissimulação (de novo apontando para a complexidade que se desenhará em breve no enredo):

Por isso, D. Constança via quase um sacrilégio na pouca consideração de Maria Luísa pelo marido.

E para combater o ressentimento que devia ter provocado no genro a má conduta da filha em the acolher o amigo, desfez-se em amabilidades e em perguntas sobre esse Flávio que nunca ouvira falar, e que não a interessava absolutamente. (PEREIRA, 2006, p. 
Assim temos que enquanto Maria Luísa é tecida através das atitudes que tem ou que condena permeadas pelo tom irônico que assume a narradora, a ideologia da voz narrativa vai se revelando a partir deste posicionamento que assume não só com relação à Maria Luísa como também às outras personagens. O que aponta para sua crítica com relação ao comportamento de Artur enquanto marido, também à Lola, a mulher moderna, que por tempo determinado desfruta de certa independência e que, no entanto, é apresentada aqui em sua futilidade de boneca. E à dona Constância, que em criticando o que considera displicência com o marido, revela-se, ela mesma, cumprindo seu papel de mulher tradicional, mas pouco honesta em seu interesse.

Parece-nos, portanto, que diante da ironia narrativa, todas as personagens desta primeira parte do romance estão em xeque. Todas estão fora de lugar, as principais, conforme exposto, e também as secundárias. Assim sendo, a morte de Célia, consequência de sua solteirice, também é narrada de forma rápida que quase Ihe imputa irrelevância. A ranzinzice de D. Laura, a irmã solteira de Dr. Lemos, e a dele próprio serão permeados de tom irônico, assim como recairá ironia sobre Flávio, em sua curta participação na narrativa.

Desta forma, não só Maria Luísa aparece como antítese no romance, como também a narradora. Isso será reforçado ainda mais pelos diversos comentários que ela tece ao longo da primeira parte do romance.

\section{O comentário}

Os comentários narrativos vão se tecendo ao longo de todos os capítulos dessa primeira parte. Interessa-nos principalmente destacá-los enquanto: 1. antecipadores de ações narrativas, como explicativos e preparadores da futura leitura, intencionalmente induzindo o julgamento. 2. apresentação da opinião da narradora acerca dos fatos, para além das ações ou da concatenação dos eventos que já organizam a sua perspectiva.

São comentários de cunho analítico e que, formalmente, intuem uma participação mais incisiva desta narradora na história, prospectando sua opinião 
sobre os fatos. Não estamos aqui falando ainda da especificidade da autora implícita, aos moldes de Wayne Booth, que tem, segundo Dal Farra, "olhos que dominam os horizontes de lado a lado e que regulam à sua vontade, numa "espécie de Jano que conserva em seu olhar o passado e o futuro" (1978, p. 23). Pelo contrário, ainda que possamos compreender uma autora implícita no limítrofe organizacional da narrativa, existe uma narradora opinativa escolhida por esta autora implícita.

Em não sendo um romance em primeira pessoa e constando a opinião desta narradora em comentários que interrompem a ação narrativa, a narradora se impõe enquanto autoridade na condução da narrativa, sustentando sobre as outras personagens o privilégio da onisciência que aquiesce as suas avaliações. Uma narradora que, para além de tudo observar e presenciar, também irá opinar. Segundo Maria Lúcia Dal Farra, ainda em seu estudo sobre o narrador ensimesmado, há dois tipos de manifestações da narrativa em terceira pessoa, uma moldada pelo discurso "referencial", cujo caráter é "objetivo", e outra através das intrusões do narrador, cujo discurso é "avaliatório". Parece-nos, nesse sentido, que a narradora da Maria Luísa da primeira parte do romance imprime nele o cunho da avaliação. Esclarece-nos Wayne Booth:

O comentário sobre as qualidades intelectuais e morais dos personagens afecta sempre o modo como vemos os acontecimentos em que esses personagens se movimentam. Portanto, sobrepõe-se imperceptivelmente a declarações directas sobre o significado e a importância dos próprios acontecimentos. (BOOTH, 1980, p. 210211)

No entanto, é preciso destacar que esta narradora não enfatiza sua onisciência em relação à protagonista nesta primeira parte do romance. E é justamente este comportamento que melhor pontua na estrutura da primeira parte $o$ distanciamento entre as duas e, ao mesmo tempo, também justifica as ações de Maria Luísa, direcionando a leitura, quanto a experiência do adultério.

Destacamos, porém, o capítulo $X$ (p. 47), cuja existência se restringe ao comentário narrativo, que determinará o caráter da relação de Artur e Flávio antes 
mesmo da aproximação entre este e Maria Luísa, numa espécie de preparação da leitura para o evento que virá a acontecer:

Sob apelação genérica de amizade, por exemplo, enfeixamos uma infinidade de atrações de natureza diversa. Desde os amigos de café, a quem damos de longe em longe dois dedos de prosa, até aquelas por quem daríamos tudo.

Entre elas, há uma muito interessante. E muito comum.

A dos amigos de sala de visitas, por assim dizer. Daqueles a cujos olhos gostamos de brilhar. E de brilhar no sentido em que eles 0 entendem. Mesmo que seja contrário ao nosso. Todos nós as encontramos, na vida, essas pessoas ao lado das quais alguma coisa nos impele a tentar parecer o que elas são. Ou o que julgamos serem.

Mas é raro se acharem no número daqueles a quem queremos muito. $\mathrm{E}$ nem sempre, conscientemente, as admiramos. Representam, porém, via de regra, uma qualidade que desejaríamos possuir ou um gênero de vida que sonháramos poder levar. (PEREIRA, 2006, p. 47)

Este comentário antecipa não só a ordem que opera na relação entre Artur e Flávio, como também aquela que operará a deste com Maria Luísa, uma vez que Flávio buscava ali alimentar o seu poder de sedução, posto em dúvida na constatação de que os outros construíam algo - a família que ele recusa - enquanto ele "julgara poder parar, fixar-se na posição de rapaz elegante, seduzido ele próprio pelo seu poder de sedução" (p. 61).

Ressalta-se ainda que seus comentários irrompem na primeira parte da narrativa denotando seu ponto de vista com relação às personagens e seus destinos a partir das avaliações que expõem ideologias que por ali se anuem. Sabemos assim de uma narradora cujos preceitos católicos estão presentes, mas que questiona a superficialidade da prática da Igreja Católica (p. 56), que forja juízos sobre a mulher em flerte com acepções da ideologia patriarcal, enaltecendo o sentido da família, embora se contraponha aos formatos ali delineados pelas personagens do romance, que critica a "desorientação" do mundo moderno (p. 56), embora também trace questionamentos sobre a "tradição" etc. Uma narradora que 
também forja em si as mesma contradições presentes em Maria Luísa, no trânsito de antigo e novo paradigma. Antepostas durante toda a primeira parte narrativa, a partir do aparecimento de Flávio e da incursão autoritária de Artur, resultante da perspectiva reflexiva de Maria Luísa isolada de suas funções de mãe e esposa, e, principalmente, depois que esta rompe com o modelo ideal ao cometer o adultério, há uma identificação entre as contradições que marcam essas duas vozes que irá se refletir na mudança da perspectiva narrativa como já mencionamos. Para tanto, os comentários vão se tornando cada vez menos irônicos com relação à Maria Luísa, antes do silenciamento ${ }^{14}$, elucidando que a narradora abrirá espaço para Maria Luísa à medida que escolhe se ocultar mais na narrativa. Assim demarca o seu último comentário aos moldes desta primeira parte com a constatação, que não sabemos se dela ou de Maria Luísa, sobre a realidade, vista aqui, agora sim, sem a lanterna mágica, que pode tanto remeter ao encantamento de Maria Luísa com Flávio ou à ruptura com o modelo ideal no casamento. Vejamos:

E acordavam nela uma mulher desconhecida, revoltada contra a mesmice da vida, vibrante de loucas aspirações.

Parecia traspassa-la esse olhar inquiridor, e um pouco inquietante, que sentia pesar sobre o seu. Seria a frescura da montanha que a arrepiava assim?....

Quando a lanterna mágica terminava, era como se tudo ficasse escuro. Cair outra vez na realidade, depois da viagem ao país das maravilhas... Por quê? (PEREIRA, 2006, p. 73)

Postulando assim o tom irônico e o comentário na condução narrativa desta parte, a narradora nos antecipa os questionamentos que virão logo a seguir. Se expõe em Maria Luísa (ou qualquer mulher?) a impossibilidade de se cumprir determinados papéis sociais com perfeição - pois tamanha exigência só poderia ser inatingível -, também supõe-se óbvio que algo irá acontecer para redimensionar as posições maniqueístas retratadas, a priori, como opostos na protagonista. $\mathrm{Na}$

\footnotetext{
${ }^{14}$ Restringimos este silenciamento à mudança de proposição da narradora quanto aos seus comentários. O romance continuará sendo narrado em terceira pessoa, o que implica na presença da narradora. No entanto, já não serão mais presentes as suas frequentes avaliações, agora substituídas pelas reflexões de Maria Luísa.
} 
segunda parte do romance ("A Montanha"), a narradora se ocupa das reflexões de Maria Luísa e cria, com isso, uma junção indissociável entre as duas em alguns trechos. Na primeira parte do romance, a narradora aponta exatamente para onde o universo de Maria Luísa, calcado na restrição de si como modelo de esposa e mãe, ameaça ruir. E, sendo assim, aparece-nos visível pela voz narrativa o quão falacioso era o paradoxo entre insubmissão doméstica $X$ subordinação social. Através da ironia que questiona posicionamentos que pareciam irrefutáveis, pela dinâmica que apresenta seu retrato, transparece a óbvia ordem complexa estabelecida entre o paradigma antigo e o novo na ordem social sobre a estruturação da figura da mulher no romance. A narradora, contrariando as certezas de Maria Luísa, antecipa a complexidade que irá amoldar a personagem quando esta assume a condução da narrativa através do discurso indireto livre, o que ocorre, efetivamente, desde o início da segunda parte do romance.

\section{Orquestração do feminino e a transfiguração da outra: a narradora com Maria Luísa}

Como apontado anteriormente, há uma mudança estrutural da narrativa que é marcada pela organização paragrafal, que antes (do primeiro capítulo da parte II p. 77-81) conformava um alinhamento mais longo, e agora se torna reduzida a uma ou duas frases, compondo um ritmo que remonta ao fluxo de pensamento de Maria Luísa, neste primeiro capítulo da segunda parte, para depois variar entre as duas formas dos outros capítulos em diante, de acordo com a necessidade de circunscrever o fluxo narrativo ao ritmo do pensamento, o que é possibilitado pelo discurso indireto livre concedido à personagem.

Respaldada pela onisciência, a narradora irá revelar um estado psíquico da personagem que, através da experiência vivenciada a partir de sua história com Flávio, passará a compreender-se ou a ter uma consciência mais esclarecida da opressão a que está submetida. Isso porque, parece-nos, a infidelidade feminina rompe com o paradigma principal do casamento - a supressão dos desejos da 
mulher $^{15}$. O nível de consciência de sua condição resplandece em Maria Luísa após sua ruptura, já demarcada aqui, com as certezas sobre a instituição casamento, que começa a ocorrer a partir de um sério desentendimento com Artur e se concretiza em sua experiência com Flávio. Podemos aferir que na segunda parte da narrativa dois processos, o segundo consequência do primeiro, delinearão a modificação da voz que narra: 1. a conscientização do lugar da opressão da mulher em Maria Luísa, através de uma consciência que perpassa determinado grupo de mulheres, numa manifestação mais coletiva do que antes era individualizado; 2. a transformação da voz narrativa (acarretada pelo processo 1) de preponderância em terceira pessoa distanciada para preponderância nas reflexões da personagem.

O que temos então é que a estrutura em duas partes da narrativa corrobora o processo de transformação, importante para a construção do romance, que indica algo essencial em sua composição: a estruturação da voz na primeira parte, ao se subscrever dessa forma irônica, aponta para aquilo que era, ao cabo, a falaciosa exigência social (diga-se: de ideologia patriarcal) imposta sobre uma mulher criada para ser modelo. Não se restringido a isso, esta voz também nos faz subentender que o posicionamento da protagonista ao assumir este papel na esfera pública (social) e não na esfera privada (doméstica) a conforma num lugar contraditório que elucidará uma certa desordem presente no contexto social em que o romance foi gerido. A desordem, aqui tencionada como contradição, acobertada por uma suposta ordem - na sistematização da vida da personagem -, estrutura a Maria Luísa da primeira parte narrativa.

Mas não só, a narradora, que na primeira parte do romance assume papel tão intromissivo, impondo-se em avaliações para além da observação dos fatos, também nela recairá esta contradição. Enquanto se posiciona ironicamente perante quase todas as personagens, ela elabora seu incômodo com as posturas dessas personagens e vai assim tecendo um repertório crítico à mulher moderna (Lola), ao novo patriarca (Artur), a mulher tradicional (D. Constância), ao sedutor (Flávio) e,

\footnotetext{
${ }^{15}$ Reich defende em seu argumento sobre o papel da economia sexual na sociedade patriarcal e no estado autoritário: "A economia sexual não precisou desvendar o conteúdo e os mecanismos da subjugação de qualquer espécie; eles estavam obviamente visíveis em cada lei bem como em cada fenômeno cultural do patriarcado. (...) A lei sexual tzarista, bem como qualquer outra lei sexual reacionária, exprime abertamente o ponto de vista da economia sexual a esse respeito: o objetivo da ordem moral autoritária é a subjugação sexual. Onde quer que se encontre regulamentação moral, não se pode falar em liberdade real" (REICH, 1966, p. 204).
} 
principalmente, a mulher que parecendo socialmente tradicional, resvala certa modernidade em relação à sua vida doméstica (Maria Luísa) - ajustando, apesar do cumprimento de seu papel social de esposa e mãe, certa autoridade relacionada ao marido (até, como já ressaltamos, a briga que ocasiona a primeira fissura nesta autoridade). Quando, no entanto, assume uma voz narrativa ligada ao monólogo interior de uma Maria Luísa que projeta certa quebra dessa identidade (seu papel exclusivo, como mulher, de esposa e mãe), deixa-nos assistir com mais proximidade a esta personagem, dissipando a impressão de superficialidade que a distância antes ocasionava. Maria Luísa passa assim, através da perspectiva narrativa, de antítese desse todo antes, para a síntese do grupo que representa. A narradora se aproxima dela, então, quando a representação social do modelo ideal é quebrada pelo adultério, ocasionando a fissura no modelo, e ela passa então a questionar o seu papel, conscientizando-se dos limites que lhe são impostos.

Segundo Edwirges Almeida, a mudança que ocorre nas protagonistas de Lúcia Miguel Pereira, se não se dão na ordem da ação, apresentam-se na ordem do pensamento, e Maria Luísa adquire assim uma "consciência domesticada" (2011, p. 84). Há, portanto, uma mudança da ordem do pensamento, que lemos como uma mudança no sintagma estrutural do romance conduzindo a individualidade (reduzida) para a coletividade (ampliada). Maria Luísa, após o adultério, ao romper finalmente com sua até então estancada posição, abre espaço para as elucidações acerca do seu lugar social. Esse movimento é acompanhado pela narradora, que abre mão da ironia e concomitantemente de seus comentários. As vozes fundidas corroboram a conformação da síntese através do processo de conscientização que atravessa a personagem e reverbera na voz narrativa.

É nesse sentido que confiamos haver aqui a presença de uma narradora marcada por um ponto de vista da mulher que refletirá uma voz que reverbera certa experiência social feminina. Ao se posicionar de forma irônica com a protagonista enquanto esta segue irrestritamente as determinações da ideologia de uma sociedade patriarcal com ares modernos, e ao optar por privilegiar as reflexões da protagonista quando esta passa a tomar consciência da opressão a qual está submetida, revela-se uma escolha indubitável por esse ponto de vista no contar naquilo que a acepção de determinada experiência social de mulher pode possibilitar. O que de maneira alguma quer dizer que não será problemático o desenlace que começa a se desenhar neste momento. Muito pelo contrário, se 
pensarmos (e devemos pensar) que este ponto de vista também está tensionado pelas ordens de uma ideologia patriarcal, é-nos óbvio que sua solução não será eximida de complexidade e/ou contradição, como nos antecipa a narradora através da mente de Maria Luísa:

Só agora via que apesar de tudo muitos laços a prendiam aos que a cercavam, e começava a cuidar das atitudes. Precisava deles... sentia que a vida não podia ser diferente do que fora até então. $O$ passado podia estar errado, mas o futuro estava delineado por ele.

Teria que se cingir ao caminho traçado por aquela impassível Maria Luísa, fictícia e cega. (...)

E porque não queria morrer, porque tinha medo da morte e do que se the seguiria, era preciso mantê-las firmes, as amarras que a retinham. E não mostrar o que era, nem o que sentia, nem o que pensava para não afastar os que a protegiam contra si e contra os seus impulsos desgovernados. Para que não se horrorizassem. $E$ não a enxotassem como um cão leproso. (PEREIRA, 2006, p. 95)

Faz-se em Maria Luíza um despertar da consciência de sua condição de mulher que se a revolta, não a salva de modo algum. Que ilumina determinados aspectos de sua própria vida em meio a uma sociedade opressora que a condena a renegar "seus impulsos" que a equivaleriam a um "cão leproso", mas isso por si só não a absolve. Clarifica, mas de forma alguma soluciona o seu problema. Mesmo porque, visto suas condições materiais de mulher dependente do marido, para além da opressão moral que o ambiente social opera, seu problema é indissolúvel. Seu desejo não the pertence e se ela o toma para si de alguma maneira (aqui, confabulado no adultério) não o será sem sofrer punição, que independe do conhecimento alheio, podendo ser apenas circunstanciada pela culpa introjetada. Sendo assim: terá que ceder, terá que superar, terá que fingir, para os outros, para si mesma, dissimulando agora o que antes forjava.

Há aqui uma transmutação das percepções de Maria Luísa que perpassa pela voz narrativa como sensação (de isolamento ou perda): "Tão triste e tão só. (...) Entre ela e os outros havia sempre a barreira do seu segredo" ( p. 119); memória: "As recordações que atormentavam - e deliciavam (...)" (p. 87); ou observação, especialmente no que tange aquilo que antes lhe vinha como oposto com relação às 
mulheres, sobre as quais passa a projetar uma espécie de lupa espelhada capaz de por em xeque o reducionismo de outrora. Ao analisar e querer defender Lola diante de Artur, por exemplo, enxerga a si mesma na outra:

Vendida a casa, Lola estava morando num hotel. E continuava cada vez mais elegante, dissera-lhe o marido.

- Não tem cabras e vende cabritos, rematara com ar de censura.

Lembrava-se ainda do mal que lhe fizera essa insinuação de Artur. Era como se o erro as tivesse irmanado.

E que direito tinha ele de acusar a cunhada, ele que pactuara com a má conduta da mulher?

Tivera de se dominar para não defende-la. E, entretanto, intimamente, também a condenava... Era tão frequente isso: ver-se cerceada, coagida quase pelo seu antigo modo de pensar. Odiava a mulher que fora, e que the envenenava a vida com os seus princípios. Tinha a certeza de serem falsos. E não podia deixar de sentir como se não o fosse. (PEREIRA, 2006, p. 96)

No entanto, mesmo que se sentindo irmanada à outra, que aqui interpretaremos como uma possibilidade de se observar como igual em uma situação de opressão, Maria Luísa ainda é perseguida pela sombra dos princípios que modulavam sua rigidez e austeridade de antes, a tornando inflexível e incapaz de se afinar com Lola. E que se anteriormente eram já estipulados como superficiais pela narradora irônica e comentarista, aqui tornar-se-ão a seu ver, agora coadunado com a narradora, falsos. Se lá, no entanto, sentia superioridade (de silogismos puro) com relação à cunhada, aqui, por sua vez, o sentimento que a toma será impulsionado pela inferioridade que se arroga quando observa certa desenvoltura da cunhada para lidar com a mesma opressão social (afinal, o namorado de Lola separou-se para se casar com ela, e se ela não destruiu a própria família, destruiu outra, como pensa Maria Luísa): "Era como se tudo fosse muito fácil, muito simples para ela. E bem menos importante do que uma mecha rebelde de cabelos que the caía sobre a testa e a todo momento consertava" (p. 97). Podemos perceber, portanto, que Maria Luísa já não rejeita a liberdade de Lola, senão porque ela 
própria é incapaz de atingi-la. Há a suplantação da sua anterior subordinação social por esta tomada de consciência que reflete na outra maior liberdade.

O mesmo procedimento se opera com relação à $d$. Constança e, se antes Maria Luísa discordava absolutamente da mãe, não lhe abrindo possibilidade de fala, agora perante D. Constança terá rememorado um sentimento infantil de obediência e confiança. Se na primeira parte narrativa ao ser questionada pela mãe quanto ao comportamento com o marido, Maria Luísa posicionava-se irredutível, aqui, quando a pedido de Artur, D. Constância dirige-se a si, Maria Luísa é jogada para o lugar da culpa, incapaz de objetar as impressões do marido (que a remete para o remorso e o desespero ao se julgar culpado por sua má disposição), a não ser no sentido de tranquilizar a ele e a mãe:

Ouvindo-a, Maria Luísa tinha a impressão de ser ainda uma criança. Uma criatura nova, sem inquietações nem passado. Uma menina malcriada e cheia de vontades, que estava fazendo birra.

É talvez o maior bem que as mães representam para os filhos adultos, essa infância de que os reveste a sua presença. Elas guardam a ingenuidade que estes tiveram um dia. Guardam-na para eles, porque sempre imaginam que ainda a possuem.

A voz cansada de D. Constança, a voz tão igual, corria como um riacho manso sobre a efervescência da moça. (PEREIRA, 2006, p. 110)

Como podemos perceber nessa perspectiva da narradora que perpassa Maria Luísa, a mãe, que antes incomodamente representava a resignação submissa diante da vida doméstica, agora se impõe como conforto, rescindindo a dualidade entre ela e a filha de insubmissão desta diante da submissão daquela na vida conjugal. Maria Luísa também vê com novas matizes D. Constança, impulsionando a percepção do todo contraditório presente nela própria.

Encaminha-se assim a voz narrativa, revelando uma Maria Luísa cujas certezas se dissipam e se transmutam conflituosamente em questionamento. Rompida a sua postura intransigente e intransponível de outrora, Maria Luísa é neste momento conduzida pelo sofismo, examinando seus papéis, as imposições que Ihes são impugnadas, Deus, em um exercício que se não evidencia totalmente 
a complexidade de sua condição (porque isso poderia ocasionar uma ruptura definitiva com o lugar ao qual pertence), permite-lhe ao menos enxergar a inviabilidade de corresponder às expectativas que sobre si são lançadas, dentro de um universo que está, ele todo, desordenado. Torna-se uma pessoa triste e a palavra triste se repete na contemplação de si mesma em seus pensamentos. No entanto, nada anteriormente projetava uma imagem feliz em Maria Luísa. O que se estabelecia era um universo austero em certezas que se rompem a partir de sua infidelidade no casamento, resultando em uma instabilidade constante. Isso passa a determinar o clima que norteia a narrativa até que dois eventos lhe tiram de si para devolvê-la ao mundo, invertendo temporária ou definitivamente o foco.

O primeiro é a eclosão da Revolução (p. 115). E aqui temos que se a crise financeira do país se transpôs sobre ela através dos abalos ocasionados em e por outras personagens que a afetam de maneira definitiva, jogando-a para um aparte da vida sistemática que levava, a Revolução devolverá sua necessidade em se voltar para a realidade exterior, que lhe permite olhar para os acontecimentos fora do seu mundo doméstico, fora, portanto, da esfera privada, despertando, pela primeira vez na protagonista, o interesse para com esse mundo exterior:

A ameaça, em que a via, veio acordar em Maria Luísa o interesse pela sua terra. E pela sua gente.

Sofria por elas, fisicamente quase.

Nas primeiras noites, em que choveu muito, não conseguiu dormir. Uma aflição aguda a angustiava. Era como se estivesse lá fora no frio e no escuro, alguma coisa que lhe fosse muito cara... (...)

Um grande desejo Ihe invadia de ser útil também.

Era todo uma face nova da vida que lhe apresentava.

Como vivera isolada, até então, e egoisticamente...

Não era legalista, nem revolucionária: não sabia de que lado estava a razão. Só sabia que todos sofriam. E sofriam por um país que era o seu, que era o de seus filhos. (PEREIRA, 2006, p. 116)

Notemos que aqui paira sobre Maria Luísa a necessidade de olhar para a sociedade que está a sua volta não apenas no sentido de responder às exigências a que está submetida desde o início, representando o modelo mãe-esposa, mas também em refletir sobre essas exigências, ainda que atinadas pela dúvida. Os 
abalos sofridos por Maria Luísa ao ter suas inflexões postas em xeque operam, aqui também, no sentido de libertá-la daquilo a que tinha que corresponder (e já não corresponde), permitindo que sua perspectiva se posicione para além do ambiente familiar. Sabemos que a Revolução de 1930 está em pauta aqui, mas o que importa, para nossa observação sobre o desenvolvimento da personagem, é que ainda que esteja presa às questões da vida familiar, a crise e a Revolução irão lhe afetar de maneira definitiva: a crise lhe retira de seus ilusórios domínios e a impele para uma avaliação de si, a Revolução a conduz à reflexão sobre o que está além de sua vida doméstica.

Então, apesar da culpa de preceitos católicos que se acopla em Maria Luísa após se relacionar com Flávio, passada a nós através do discurso indireto livre pela narradora, há aqui também um segundo movimento narrativo no sentido de orientar nossa leitura: a infidelidade de Maria Luísa abre espaço na personagem para que esta possa olhar para fora do núcleo familiar, antes único foco de sua atenção. Reverbera-se numa espécie de lampejo sobre sua condição social, que também é resultado de eventos da realidade política e econômica do país que refletem em sua vida e a evocam a se pensar socialmente. A protagonista passa então a não só discernir seu lugar social naquela sociedade opressora, como também a discernir o de outras e outros.

Como mencionado anteriormente, não será sem contradição que se faz esse passo na ordem da narrativa. Passada a "borrasca" (p. 118) que a tira de seu torpor interior, Maria Luísa volta-se de novo para si. E é um segundo evento que a move mais uma vez do seu ensimesmar: o encontro com a menina cega. Sentindo a necessidade de contar a sua culpa a alguém, Maria Luísa tem contato com uma menina pobre e cega durante um evento na igreja. Será essa menina e sua confissão que irão, de alguma maneira, a redimir.

A menina por apresentar uma força extraordinária aos olhos de Maria Luísa:

Nada a desanimava. Nem as dificuldades de uma doutrina que não podia decorar como as outras, nem as brincadeiras movidas pela perversidade dos companheiros. Obrigava a inteligência rudimentar a um esforço exaustivo, e a sensibilidade doentia a um convívio cruel. Aliás, a mãe, uma lavadeira, interrompia o serviço para 
acompanha-la e protegê-la tanto quanto possível. (PEREIRA, 2006, p. 126)

E a confissão por a libertar de si mesma:

Era o seu orgulho, que se abatia.

Era a humildade que a purificava.

Era o amor que entrava nela, e vencia tudo, o amor de Deus e o amor das suas criaturas. (PEREIRA, 2006, p. 135)

A contradição aqui se faz presente e confunde: se Maria Luísa foi obrigada a olhar de fora o núcleo familiar, o que possibilitou que se voltasse para toda a opressão que a envolvia, e se essa opressão estava também consolidada pelas diretrizes da Igreja Católica, que penhorava à mulher a submissão ao casamento (irreversível), como pode ser a mesma igreja que culpa, a que liberta? Nesse sentido, pensamos que aqui está exposto através da personagem não só o catolicismo apontado já na obra de de Lúcia Miguel Pereira em diversos estudiosos, como Edwirges de Almeida (2011), mas a contradição que pairava sobre a mulher burguesa do início dos anos 1930 no Brasil. Ainda que se pense socialmente, quais seriam as condições materiais efetivas de se manter fora do núcleo familiar para uma "dona de casa", caso desejasse levar ao fim sua necessidade de se libertar? As condicionantes nos parecem tão densas que dificultavam até a reflexão sobre isso, quanto mais o agir. E essa densidade opera não só na protagonista, como na própria voz narrativa, que aqui já não dirige, com opiniões e comentários, a leitura.

Sabemos que o trabalho era raro na vida das mulheres do grupo social representado por Maria Luísa e, portanto, a dependência financeira do marido era 
um fator bastante limitador ${ }^{16}$. Para além disso, o divórcio só foi legalizado no Brasil em 1977, o que é pressuposto óbvio de que não era uma opção para uma mulher como Maria Luísa na década de 1930 se separar. Ainda, se isso fosse possível, restringida até então ao seu papel de esposa e mãe, Maria Luísa se conforma com a reflexão, que não engendra ação, porque disso dependeria uma modificação de toda uma estrutura social que age sobre ela. Se ela não vislumbra essa possibilidade, tampouco a narradora o faz. E aqui, novamente, as duas se coadunam, se dessa vez não para questionar a ideologia a qual estão submetidas, agora para demonstrar o quanto ela incide sobre o pensamento. $E$ assim, se a opressão em que Maria Luísa se vê enveredada perpassa pelo marido e pela igreja católica, naquilo que mantém os paradigmas do casamento, é, no entanto, no marido e na igreja que estará o seu destino. No marido, por ser isento da culpa da infidelidade de Maria Luísa (Artur além de se negar a ver a infidelidade da esposa com o amigo, conforme fica explícito na página 92, ainda se culpa pelo distanciamento da mulher - configurando-se, de certa forma, como um homem exemplar). Na igreja, por tornar possível sua humildade e resignação, oferecendo o perdão (perdão por uma culpa forjada, que lhe foi incutida e que suprime a própria consciência, em prol da obediência à ordem estabelecida).

Maria Luísa não volta à estaca zero, porque ela se transformou - seu olhar sobre si mesma se transformou. Mas ela não é capaz de transpor as limitações que seu lugar social the atribui. Assim sendo, resigna-se, vendo-se, novamente, como única responsável pela condição acachapante em que se encontra:

$E$, entretanto...

16 Discutiremos posteriormente premissas teóricas que levam a esta questão financeira, mas podemos adiantar aqui que Lúcia Miguel Pereira estava a par da discussão e concordava com Virgínia Woolf, embora crítica a alguns de seus pressupostos feministas, em Um teto todo seu ( $A$ room of one's own). Diz Pereira (1994, p. 99): "A Room of One's Own com todas as deficiências que Ihe dá o seu caráter feminista é delicioso de graça de espírito, de finura. Em 1928, pediram-lhe que fizesse uma conferência sobre as mulheres e o romance: daí nasceu esse ensaio, de cujas afirmações se pode algumas vezes discordar, mas onde Virgínia está toda, com a sua ironia, os seus requebros airosos, as suas faceirices e a sua honestidade intelectual. Esta é tão forte que, partindo para provar que as mulheres são, na literatura como na vida, pobres vítimas dos homens, ela chega inesperadamente a conclusões que tanto se aplicam a uns como a outros: a de que não se pode escrever sem ter quinhentas libras anuais e um quarto munido de sólida fechadura. Evidentemente, essa quantia significa um mínimo de bem estar material, e o quarto, a liberdade de pensar sem ser importunado pela presença ou pelas opiniões alheias." 
A nuvem tempestuosa, a nuvem de tristeza e de remorso, de longe em longe se abatia sobre Maria Luísa.

Mas ela sabia que se desfaria na chuva fecundante das lágrimas resignadas...

E regaria os brotos tenros da esperança...

O seu antigo eu, o seu eu calculista e vaidoso, também reaparecia por vezes, e o egoísmo a dominava, então.

Mas ela sabia que a "a carne é fraca, é preciso orar e estar atenta". Nada mais a perturbava, nada...

Desvendara o segredo da vida... entendera o sentido do pecado e da dor.

Cheia de confiança e cheia de humildade, repetia as palavras da ceguinha, as palavras que não compreendera:

- Não faz mal... não foi desta vez, mas há de ser de outra... (PEREIRA, 2006, p. 140)

Maria Luísa assume, portanto, os lados bastante contraditórios a que estavam submetidas as mulheres burguesas da sociedade de 1930 no Brasil. Caminhando impreterivelmente de um polo ao outro conforme os eventos que se sucedem em sua vida, e alternando-os a partir de sua experiência, ela representa as inquietações que pairam sobre esse lugar social, que na sociedade patriarcal suprime-se em culpa e limita-se à ausência de solução.

A narradora, por sua vez, ao se aproximar de si através das reflexões de Maria Luísa, expõe, ela própria, as suas fissuras. Na primeira metade do romance, a narradora assume esse caráter de avaliação, conforme procuramos apresentar anteriormente. Na segunda parte, no entanto, ela apela para o pensar da protagonista, que passa a dominar a narrativa. Esse movimento a aproxima da perspectiva da personagem - a narradora passa então a se escamotear na objetividade das observações e nas reflexões de Maria Luísa, em alguns momentos coadunando-se com esta. O que isso nos revela? Em primeiro lugar que há também uma transfiguração das distinções narradora, que se antes apontava as outras e a si mesma como antítese de Maria Luísa, agora passa a compartilhar da mesma perspectiva, o que só ocorre a partir da tomada de consciência da condição social da mulher que se opera em Maria Luísa. Então não é só Maria Luísa que passa a se refletir nas outras, a narradora passa a se refletir em Maria Luísa, indicando que há 
um caminho de confluência, possibilitado pela conscientização. Uma vez perpassada pela conscientização, tal comportamento é um indício ideológico da narradora, embasada em princípios feministas que podiam ser identificados na época, como a necessidade da mulher de reconhecer algumas das opressões que atuavam sob sua constituição, embora sem possibilidade de refutar as organizações sociais $^{17}$. Essa confabulação ideológica que já tinha se dado anteriormente pelo movimento antitético, a crítica a todos os estereótipos, é reorganizada aqui a partir do movimento sintético e ocorre uma notável identificação entre essas vozes de mulheres.

Em segundo lugar, como consequência dessa coadunação entre as duas a partir das reflexões de Maria Luísa, também fica evidenciado a contradição presente na narradora, uma vez que, ainda que se confrontasse com a postura de modelo social de esposa e mãe representado por Maria Luísa, ela parece reconhecer, através de certo silenciamento de suas avaliações, que o único lugar possível para sua constituição enquanto mulher, ainda que adquira consciência de gênero, é o casamento e a família. Pois bem, se é justamente portar-se como modelo ideal de mulher numa sociedade patriarcal que lhe afere a identificável antipatia da narradora, a ausência de saída aponta não só para uma Maria Luísa em crise após romper com seus valores morais a partir do adultério, mas também para uma narradora em crise, que se abstém de seu posicionamento antes crítico.

A redução estrutural ${ }^{18}$ se faz presente então na concepção da voz narrativa se pensarmos a que estavam submetidas essas mulheres do início dos anos 1930 no Brasil. Desde o final do século XIX, ocorre uma série de reajustes na ordem social uma vez que a família tradicional patriarcal vinha sendo substituída pela família burguesa urbana. É neste contexto que se insere Maria Luísa. Na década de 1920, transformações se fizeram necessárias acerca da composição da família, uma vez que esta entrou em crise em meio às turbulências sociais e políticas. Se, em todo o caso, estava havendo uma modernização da família burguesa com a

\footnotetext{
${ }^{17}$ É importante notar que, mesmo no movimento feminista presente no Brasil dos anos 1920, com a figura central de Bertha Lutz, conforma-se um feminismo bem comportando, segundo Célia Pinto, "na medida em que agia no limite da pressão intraclasse, não buscando agregar nenhum tipo de tema que pudesse pôr em xeque as bases da organização das relações patriarcais (PINTO, 2003, p. 26).

${ }^{18}$ No Prefácio de $O$ discurso e a cidade, o crítico Antonio Candido aborda o processo que denomina redução estrutural: "isto é, o processo por cujo intermédio a realidade do mundo e do ser se torna, na narrativa ficcional, componente de uma estrutura literária, permitindo que esta seja estudada em si mesma, como algo autônomo" (CANDIDO, 2004, p. 9).
} 
manutenção, no entanto, da mentalidade da família patriarcal com relação ao papel da mulher, e se a esta é dada a incumbência de manter a família configurada em certos moldes, essas duas vozes de mulheres que dominam a narrativa de Maria Luísa (a narradora e a protagonista) apresentam em suas estruturas a crise da qual não escapa a mulher diante desse cenário. Em crise, porque se não é o modelo ideal possível, também não é na dissolução da família que encontra a sua solução, principalmente se pensarmos que na sua condição material não há forma de sobrevivência para além do casamento, a não ser na dependência de outro homem que não marido (como Dona Laura) ou na morte (como em Célia). E os caminhos são os de subordinação: se Maria Luísa volta-se para o catolicismo, agora não superficial, e para a família, agora sem a austeridade, a narradora também perderá sua voz crítica. Ficam as duas assim resignadas à condição de consciência comportada.

\section{Para além do amor, de Maria Lamas}

Publicado em 1935, Para além do amor, de Maria Lamas, traz a história de Marta, uma mulher casada com o proprietário de uma fábrica. Durante um período de férias em que Jorge, seu marido, e seu filho, Carlos Eduardo, partem para uma viagem entre Inglaterra e França, Marta viaja sozinha para o Buçaco, região campestre localizada em Aveiro, onde conhece Gabriel, por quem se apaixona. A história entre Marta e Gabriel, iniciada no clima bucólico, será levada para Lisboa, quando então a protagonista se vê às voltas com as dificuldades impostas à sua condição de mulher, principalmente naquilo que tange sua autonomia.

Entre as diferenças fundamentais de Maria Luísa e Para além do amor está a escolha do posicionamento da narradora e, por isso, o cerne de nossa comparação entre os romances se dará justamente aí. Se naquele a terceira pessoa opera no sentido de possibilitar uma transição entre distanciamento e proximidade com que apresenta e acompanha a protagonista, marcando assim o posicionamento ideológico desta narradora em duas fases, neste Marta narra sua trajetória, num formato próximo ao diário, assegurando à leitura a sua própria perspectiva. À diferença do ponto de vista, no entanto, acopla-se a semelhança da problemática do 
enredo: também é na relação com o outro, para fora de seu núcleo familiar, que Marta sofre uma transformação que incidirá sobremaneira na sua percepção de si e tudo que é tecido socialmente ao seu redor. Mas se na análise de Maria Luísa, devido à dinâmica aproximação-distanciamento, podemos separar, ocasionalmente, em duas partes a nossa análise, aqui elaboraremos uma perspectiva sobre o todo, devido à opção pela narração em primeira pessoa.

Inicialmente, podemos tecer diversas semelhanças entre os dois romances com relação ao desdobramento de enredo. Como no romance de Lúcia Miguel Pereira, em Para além do amor é no afastamento da cidade, e da sua vida urbana, que a protagonista sofrerá certa ruptura com o que se identificava, a princípio, com o tédio que lhe assegura a liberdade de refletir sobre si mesma. Assim como Maria Luísa, ali Marta também se vê apartada de sua função de esposa e mãe. Muito longe de conjecturar infelicidade com esse acontecimento, ela sente prazer na solidão que finalmente, muitos anos depois, pôde ter. Mas tal prazer, a princípio, como em Maria Luísa, não é bem vindo, uma vez que o tédio do campo a lança também ao encontro de suas próprias inquietações, tal qual é possível observar nas cenas inaugurais do romance:

\begin{abstract}
A ânsia de inquietação, que, de vez em vez adoece minha sensibilidade, trouxe-me até esse Palace adormecido no regaço da floresta. Três dias passados, o tédio tornou-se o meu companheiro inseparável, a fazer-me sentir que a serenidade majestosa da paisagem é incompatível com meu temperamento. Mais uma vez me enganei! Sim, o isolamento faz-me mal. (LAMAS, 2003, p. 31)
\end{abstract}

Sabemos desde já que se trata de uma mulher inserida no contexto burguês (sua família viaja pela Europa enquanto ela passa tempos hospedada no Palace ${ }^{19}$ ). Apesar dessa semelhança do locus enunciativo do romance (parte de uma determinada elite econômica), dá-se a diferença fundamental entre essas narrativas que determina estruturas distintas: se em Maria Luísa a voz que caracteriza a protagonista inicialmente é perpassada pelo ponto de vista de um marido, aqui a voz

\footnotetext{
${ }^{19}$ Hoje conhecido como Palace Hotel do Bussaco, o edifício foi projetado no século XIX e consta como uma das importantes edificações portuguesas de todos os tempos. Foi no Palace que se realizou a última cerimônia da monarquia portuguesa, em 1910, pouco antes da proclamação da República.
} 
que caracterizará a protagonista é a sua própria. Marta, neste sentido, por contar a sua própria história, assume uma autonomia reflexiva que Maria Luísa não terá com relação, principalmente, à dinâmica social que opera sobre ela, ao menos, como procuramos demonstrar, na primeira parte do romance. Assim sendo, é sobre a voz da narradora, e não sobre o comportamento da protagonista, que irá incidir a dicotomia que aponta para determinada condição da mulher. Esta condição é fundamental para analisarmos a ideologia que transcorre nesta voz, objetivo deste estudo. Se em Maria Luísa isso perpassa a ação e é a ação que guiará as mudanças presentes na narradora, aqui será a partir da reflexão, portanto vinculado à ordem do pensamento, que isso ocorrerá.

Assim sendo, a lógica se inverte: não é uma perspectiva masculina que irá pairar sobre a figura feminina, como lá, mas a perspectiva feminina que irá pairar sobre a dinâmica social, de maneira geral, e também sobre a figura masculina, na especificidade, como nos é mostrado na sequência de observação que Marta tece sobre Gabriel para, logo em seguida, fechar-se em um momento de observação de si mesma na abertura de Para além do amor. O que nos interessa aqui é que essa movimentação do foco narrativo em primeira pessoa suscitará logo no início do enredo as dúvidas com relação ao lugar social da mulher, diferenciando-se, assim, do retrato que é tecido de Maria Luísa pela narradora irônica na primeira parte daquele romance. Em Para além do amor, o aspecto crítico com a realidade em que se está inserida é presente desde o início, o que pode ser observado, por exemplo, na inauguração do segundo capítulo, quando, depois de narrar seu passeio com Gabriel e suas impressões da conversa e do cenário em que estão imersos, expõenos Marta:

Mas que quero eu, afinal? Que poderá dar-me a vida que ainda não me tenha dado? Eu deveria ser feliz, porque possuo tudo o que, neste mundo, torna felizes as criaturas. Tudo?

É mentira! É mentira! Há qualquer coisa mais. Riqueza, viagens, deslumbramentos e prazeres não chegaram para encher o vácuo da minha alma. Nem o casamento. Nem a maternidade. (LAMAS, 2003, p. 43-44) 
Marta adensa assim o ato de narrar por sua insatisfação com algo que ainda não pode nomear, mas que já sabemos se tratar do "raio limitador de ação", tal qual em Maria Luísa, que se dispõe aqui na confabulação da sua vida de mulher esposa e mãe. Também em distinção do primeiro romance nesta tese analisado, a protagonista de Para além do amor se enxerga, logo no início, como parte de determinado grupo social mais amplo, que elucida uma questão de gênero: "tenho certeza que essa insatisfação faz sangrar milhões de alma de mulher" (p. 44). Temos, assim, dois diferenciais fundamentais determinados no início dos dois romances: se no primeiro, a narrativa transcorre no sentido de demonstrar uma protagonista que corresponde à função engendrada por todas as imposições que a sociedade de ideologia patriarcal brasileira de 1930 imputava à mulher-modelo e que só poderá desdobrar certa consciência de gênero a partir do adultério que the impõe uma ruptura; no segundo, temos uma protagonista que já inicia a sua narrativa questionando a imposição social e que se identifica com o grupo de mulheres ao qual pertence, portanto observa-se, de saída, coletivamente.

A consciência antecipada que podemos verificar em Marta só foi possível para Maria Luísa depois da primeira parte da narrativa, quando vive a experiência de uma relação extraconjugal. E é sensível que, justamente por isso, a cena inaugural de Para além do amor seja muito próxima a cena da virada narrativa em Maria Luísa. Precisou a protagonista deste compreender - a partir da ruptura com a ordem que se sobrepunha ao seu comportamento - a sua condição social para alcançar determinada consciência, enquanto em Marta isso ocorre concomitantemente, uma vez que ela rompe porque já está em processo de conscientização acerca das questões que perpassam a sua condição de mulher.

Marta passa a se questionar a partir da mesma experiência de isolamento da sua função social (mãe-esposa). Pois bem, tínhamos em Maria Luísa uma narradora em terceira pessoa irônica que acompanhava a vida de sua protagonista com um olhar da onisciência que permitia ilustrar o que outras personagens observavam de si, assim Maria Luísa ia sendo delineada pelo olhar de outrem. Aqui é o olhar de Marta que irá incidir sobre o mundo e interessa, desde o princípio, traçar um panorama social a partir da sua perspectiva. Lá, saímos da sociedade para apreender a protagonista, aqui saímos da protagonista para apreender a sociedade, numa narrativa em primeira pessoa de uma mulher. Insistimos na comparação dessas proposições porque elas irão justamente alicerçar a força crítica que se 
desenvolve nos dois romances: no primeiro, a narradora distante ${ }^{20}$ forja uma Maria Luísa relativamente autônoma, quando esta não tem, na verdade, autonomia alguma, o que será revelado na segunda parte por uma narradora aproximada. $\mathrm{Na}$ contramão disso, com Marta vamos acompanhando a autonomização através de suas reflexões, isso porque a própria narradora cria mecanismos para nos fazer entender que está ali criando uma consciência a partir de sua experiência que nos relata.

Em Para além do amor, o tédio é elemento fundador, uma vez que ela não se retrata primeiro ante vivência cotidiana. Não há em Marta uma atividade contínua (como em Maria Luísa) até que finalmente pare em si e verifique que algo internamente lhe perturba; há, pelo contrário, a perturbação do tédio inicial que vai necessariamente imprimir movimento à narrativa através de sua reflexão. Portanto, é nessa inversão que outro elemento fulcral irrompe na comparação dessas narrativas: em Maria Luísa, o desenrolar do enredo narrativo é fundamental para a percepção de que há uma angústia na protagonista relacionada à opressão a qual está submetida, no entanto, antes é sua própria figura que parece exercer essa opressão sobre as outras personagens, o que a narradora vai revelando em contraposição; já em Para além do amor essa percepção é inerente à narrativa desde o início. Se lá existe uma narradora que nos coloca dúvida sobre a figura de Maria Luísa, em contraposição às outras, aqui a narradora nos aponta imediatamente quem é Marta e qual a tensão nela que irá conduzir a narrativa.

Esse posicionamento também fica nítido na configuração do adultério nas narrativas, o que gera consequências na construção das figuras masculinas do texto. Em Maria Luísa, Flávio pouco aparece, e Artur tem um papel secundário, revelando-se superficialmente, apenas pelos olhos da narradora (mais ou menos irônica) e no discurso de uma protagonista culpada. Por sua vez, Marta deixa-nos entrever detalhes de Gabriel, que ganha profundidade no romance à medida que é por ela descrito. Flávio tem pouca vida por escolha da narradora, Gabriel abunda em vida pela perspectiva de Marta, e trata-se de sua escolha. Flávio é o negativo quando em comparação a Artur, Gabriel é o positivo em relação a Jorge.

Aqui conseguimos captar outro aspecto fundamental que distancia as duas narrativas: se em Maria Luísa as descrições sobre Flávio são suprimidas, isso

${ }^{20}$ Referimo-nos aqui especificamente as distâncias e aproximações engendradas pelo ponto de vista das narrativas. 
acontece porque só nos interessa dar atenção à transformação que ocorre na personagem a partir da experiência do adultério, que será, de saída, um erro que ocasionará a sua definitiva ruptura com o que nela parecia a ordem normatizada. Flávio é um deslize, um deslize necessário na medida em que é através do erro em sua vida organizada sistematicamente que Maria Luísa será projetada para si mesma, elaborando refletidamente as tessituras sociais que estão impressas em sua personalidade, podendo dessa forma questionar o que antes não questionava. Gabriel, por sua vez, insurge pela voz de Marta e será parte de toda a narrativa, porque, diferente de lá, aqui esse enlace amoroso não é visto como deslize, pelo contrário, trata-se de uma escolha de uma consciência que já vinha questionando sua condição social: "e foi no adultério que encontrei essa revelação!" (p. 99).

Assim sendo, o adultério em Para além do amor não ocasiona a ruptura, porque do engendramento dela ele é resultante. No primeiro, a culpa vai desestruturar a protagonista em sua percepção, aqui a culpa não é presente, uma vez que o adultério é consequência de uma decisão autônoma de Marta através de suas reflexões acerca de sua condição. Portanto, Marta desvela-se com certa autonomia reflexiva, apesar de sua condição de mãe e esposa, o que possibilita que seu desejo com relação ao outro (Gabriel) seja explicitado na narrativa:

Apeteceu-me ajoelhar junto dele, tomar-lhe as mãos e pedir-lhe tu que és forte e bom, mostra-me essa luz que ilumina o teu caminho, ensina-me a compreender a vida no seu aspecto mais nobre e mais puro! Faz desta mulher, digna de ir contigo em demanda do teu ideal. (LAMAS, 2003, p. 64)

Trata-se, ao nosso ver, de uma inversão no papel submisso, uma vez que a protagonista assume para si a responsabilidade de viver um amor adúltero e narrar a sua própria história, na sua verdade. Não existe um olhar outro e o formato de diário aquiesce ainda mais este sentido, revelando ensejos de uma autora implícita que opta por organizar a narrativa desta forma através do olhar de uma mulher que parece se confessar a si mesma. Tal compromisso corresponde ao posicionamento de Maria Lamas com relação ao próprio ato de narrar, conforme podemos observar na passagem em que revela a sua intenção com este romance: 
Ao imaginar escrever este livro, tive duas grandes preocupações: ser sincera e ser Mulher... Assim, dei à heroína do meu romance uma alma torturada por mil interrogações, em luta com o meio ambiente e consigo própria, na ânsia de Verdade e de Beleza; uma alma onde todas nós mulheres encontraremos muito das nossas revoltas inconfessadas, das nossas ilusões, dos nossos sonhos e da nossa dor. (FIANDEIRO, 2003, p. 7-8)

Nesse intuito de contar uma verdade inconfessada habita a escolha, portanto, desta narradora em primeira pessoa que fala sobre si mesma enquanto simula falar para si mesma. O procedimento narrativo que prevalece aqui é o de circunscrever o romance a uma espécie de estrutura de diário, que na abertura de alguns capítulos deixa entrever o tempo, numa variação entre passado ${ }^{21}$ e presente. Temos assim elegido o tipo de discurso. Essa enunciação prospecta para uma laboração que, ao ser feita, conjectura sobre si. É na atualização dos acontecimentos que Marta se reflete, entre um passado através do qual relata ações que já decorreram e o presente reflexivo que é apontado principalmente no início de alguns capítulos. Tal caracterização do romance nos faz vislumbrar o tom confessional que o contorna, próximo ao que acontece na segunda metade de Maria Luísa, mas com a especificidade que estrutura a narrativa em primeira pessoa. Não é possível ignorar a intenção da autora implícita ao prospectar o enredo narrativo desta maneira, que corresponde ao projeto de Maria Lamas exposto acima.

A narradora de Para além do amor arregimenta seu discurso na voz de um eu, que será responsável pela coordenação narrativa. Limitada por um eu, ela condiciona a leitura ao seu ponto de vista, conta, assim, apenas aquilo que pode observar, sem os recursos da onisciência ou onipresença que dinamizariam a narrativa para além do seu próprio olhar, ao mesmo tempo em que circunda a narrativa, por esse motivo, por sua voz autônoma. Temos então que Marta sendo o eu de Para além do amor não nos dá nenhuma brecha para assistir ao mundo ao seu redor que não passe por si mesma na sua condição de mulher e será com esta exata lente que teremos o panorama narrativo. O resultado mais óbvio desta operação narrativa de "ambivalência como sujeito e objeto da própria estória que

\footnotetext{
${ }^{21}$ Há diversos exemplos ao longo da narrativa dessa forma de contar, podemos citar, entre outras, as aberturas de alguns capítulos: "O passeio de hoje foi uma revelação" (p. 31); "passei a tarde ontem com Gabriel" (p. 130) etc.
} 
conta" (DAL FARRA, 1978, p. 40) é a autoridade do ponto de vista narrativo, cuja ideologia será fixa. Sobre esta especificidade de operação da voz narrativa em primeira pessoa, anuncia-nos Dal Farra, em seu O narrador ensimesmado:

No romance de primeira pessoa, através do discurso do narrador, a ideologia se torna visível, mas por isso mesmo fixa, desde que não há possibilidade de aparecimento de nenhum trânsito semântico livre, pois a avaliação está sempre explícita e garantida pelo discurso do narrador. A continuidade imperceptível de sua voz - que foi impostada pelos direitos que o discurso lhe confere - atravessa as significações mais longínquas da narrativa e de qualquer discurso que ressurja, providenciando uma estabilidade ideológica a qualquer perfeição.

Por outro lado, se a distância entre narrador e personagem for expressiva, haverá a possibilidade de confronto entre duas ideologias fixas, mas a tendência será, geralmente, a de recobrir a anterior com aquela que o narrador detém "agora", pois ele pode se rever e observar - através da visão de análise, a "par dirrière"- que ele estava errado, corrigindo-se à tona do discurso. (DAL FARRA, 1978, p. 53)

Têm-se então explicitadas as dissociações que ocorrem entre Maria Luísa e Para além do amor na elaboração discursiva. Se no romance de Lúcia Miguel Pereira temos então, ao menos durante toda a primeira metade, duas ideologias que se confrontam, sendo que a da narradora aponta - através da ironia - para uma espécie de não-verdade na protagonista, até esta conseguir acionar às suas reflexões sobre sua condição, aqui estabelece-se desde a abertura uma ideologia fixa, que será delineada revelando o seu contraponto à ideologia hegemônica, que mais uma vez aqui é desvelada através da sociedade de ideologia patriarcal. Marta falar é uma evocação ao direito de reflexão sobre sua própria vida e, por isso, as observações de Marta são, em alguns momentos, circunstanciadas também pela dúvida gerada por sua inquietação:

Não sei se existe o mundo nem o que por ele vai! 
Estou vivendo num alheamento completo de tudo o que era, ao chegar aqui, a engrenagem complicada de minha existência elegante e frívola. Sinto acalmar-me a minha sofreguidão de emoções e chega a parecer-me que se definir melhor os anseios da minha alma inquieta, como se tivesse chegado, enfim, o bem que sempre esperei. (LAMAS, 2003, p. 53)

Aos seus anseios da "alma inquieta" também responderão perspectivas de uma outra figura feminina cuja prospecção aponta para a mulher moderna, que será representada aqui por Maria Clara, a irmã de Gabriel, que aos seus olhos configurará uma espécie de espectro libertário (ainda que os condicionamentos sociais sejam, evidentemente, tanto em uma quanto em outra, limitadores).

\section{Eu e as outras}

Em Para além do amor, há duas esferas que ambientam as reflexões de Marta para as quais ela desenvolve atenção ao longo da narrativa: a de gênero e a de classe. É só quando finalmente pode enxergar às claras a sua opressão de gênero, principalmente a partir de Maria Clara, que passa a se atentar para a opressão de classe da qual faz parte. Então, diferente do binômio mais presente em Maria Luísa, que se consolida no espectro antigo e novo a fim de delimitar as possibilidades da mulher moderna na sociedade brasileira, em Para além do amor irão operar os binômios gênero e classe, espectrados também a partir da outra: Maria Clara e Joaquina.

Assim temos que se em Maria Luísa as figuras femininas (Lola e D. Constança) são configuradas no sentindo de determinar a diferença de paradigmas que, até o fim do romance, passam a atuar concomitantemente na protagonista, aqui a figura feminina em que Marta se espelha é tecida por diretrizes de uma perspectiva que não corresponde àquelas conservadoras em voga na época e que germina sua reflexão para além da ideologia patriarcal. Maria Clara joga luz àquilo que Marta vê sombra, como por exemplo, no seu ponto de vista sobre o casamento e sobre a condição de mulher, que a impele para fora do locus de passividade: 
- Afinal defende a mulher?

- Com certeza. Defendo-a no que diz respeito ao erro de sua preparação da vida e às injustiças de que é vítima. Defendo-a perante o problema fundamental da verdadeira compreensão do amor, e entendo que ela deve ter uma educação racional e sem hipocrisias, que the fortaleça o espírito e lhe dê do casamento e da maturidade aquela noção elevada e profunda que ela, em geral, está longe de ter. (LAMAS, 2003, p. 106)

Ressaltemos que é pouco depois dessa conversa que Marta decide falar com Jorge sobre o divórcio, com um impulso que sequer consegue explicar ao antecipar a fúria que sua proposição despertaria no marido: "Tão absurda parece, agora, a atitude que tomei, que prefiro reconhecer nela inconsciente obediência ao inevitável. Realmente dir-se-ia que uma força misteriosa me impulsionou a agir assim" (p. 107), ainda que sua proposta seja violentamente rejeitada por Jorge, "Enlouqueceste?! O divórcio? Nunca! Ouviste? Nunca!" (p. 109). E a partir desse posicionamento autoritário de Jorge a opressão que rege sua vida vem ainda mais à tona:

- $\quad$ E a que chamas tu de moral?

- Àquela disciplina que obriga as criaturas insensatas, como tu, a subordinar o seu procedimento aos bons costumes e aos sagrados interesses da família! (...)

Mas não vista ainda que eu sairia coberto de ridículo desta aventura engendrada pelo teu histerismo de mulher habituada a viver à lei dos seus caprichos? Continuarás no teu posto de esposa e mãe. (...) um homem de minha têmpora não aceita imposições, sejam elas quais foram! Aqui, sou eu o chefe.

$(\ldots)$

Saiu, arrebatadamente. Eu fiquei imóvel, a sentir-me pequenina e frágil como uma criança que visse surgir na sua frente um gigante. Mas foi só um momento. A reacção veio logo, instintiva, forte. $E$ agora?

É inacreditável que um homem inteligente, civilizado, negue a outra criatura humana o direito de ser feliz. Compreendê-lo-ia se ele 
procedesse assim por amor, por interesse ou por um princípio religioso. Mas, se a nossa vida conjugal é apenas aparente, se eu me recuso a aceitar seja o que for que lhe pertença, se ele só tem a religião do dinheiro e da força porque se opõe assim ao divórcio? (LAMAS, 2003, p. 110-111)

Jorge não aceita imposições, é ele que impõe e o destino de Marta estava determinado à submissão a ele. Mas o contato com Maria Clara, o mesmo que lhe deu energia para agir insurgindo-se à passividade em sua relação conjugal, produziu em si o anseio também de liberdade, como poderemos acompanhar até o final da cena de discussão entre o casal:

Para ele o mundo inteiro, a liberdade de pensar e agir como
entender; para mim a submissão incondicional e humilhante. Só para
ele, ainda, o livre arbítrio do pensamento, da inteligência, das
paixões e dos caprichos. A mim, pobre mulher, bastar-me-iam a
futilidade, os triunfos de elegância, o luxo generosamente pago pelo seu livro de cheques." (LAMAS, 2003, p. 113)

Uma vez elaborada assim de maneira evidente a consciência da submissão que lhe é imposta, há uma ruptura significativa de Marta com Jorge dentro de uma perspectiva que já era de estranhamento com o casamento (fato, aliás, que ele próprio tenta reverter). E essa consciência parece se encaminhar para exceder os limites de sua relação com Jorge, num posicionamento que projeta todo o restante de sua vida, inclusive seu papel de mãe. Marta, a partir dessa discussão, extrapola os pontos ainda cegos consequentes do condicionamento ao casamento para observar o mundo das relações humanas das quais antes mantinha distanciamento em seu confinamento familiar.

À visão de Marta, Maria Clara representa aquilo que ela própria irá chamar de mulher moderna, e, embora na estrutura geral da elaboração narrativa não seja isto o preponderante, como buscaremos apontar, aqui parece transparecer, arquitetado de forma diferente, o binômio antigo/novo que opera em Maria Luísa na composição da mulher moderna e que também irá incidir sobre o desenvolvimento reflexivo de Marta, que compara a sua formação à da outra, e as consequências disso na sua condição de mulher dependente: 
Maria Clara aceitou, desde que soube raciocinar, a ideia de contar consigo mesma para conquistar a sua independência. Em vez do meio frívolo, eivado de erros, onde desabrochou a minha mocidade, ela teve a convivência dos livros, das professoras e das colegas, em horas de estudo e em horas de alegria despreocupada e ingénua.

Comparando-me com Maria Clara reconheço-me banalíssima e inferior. Ela é uma rapariga equilibrada e inteligentemente moderna, que sabe dar à própria elegância um sentido prático, e multiplicar as expressões da vida pelo trabalho, pela arte e pelo encanto de certas horas serenas, como aquelas que passamos conversando, na varanda da sua casa, em frente do mar, à luz esmaecida do crepúsculo. (LAMAS, 2003, p. 99; 102)

Maria Clara é assim o invertido positivo na condição de mulher que Marta vinha vislumbrando até então, porque tem autonomia econômica (ainda que os limites sociais também tenham tirado dela a possibilidade de realizar o sonho de ser médica) e intelectual. Nessa perspectiva, Marta, com sua formação, representa esse papel do antigo e Maria Clara do novo.

Além dessa binomia, que irá resvalar no processo de conscientização de Marta, há outra que também opera, aqui relacionada à classe, e será circunscrita à figura de D. Joaninha, cuja proximidade com Marta ocorre a partir de um evento circunstanciado fora da sua vida privada. Assim como a Revolução em Maria Luísa, que atrai a protagonista para fora do seu núcleo familiar e de seu drama particular, permitindo que ela enxergue agora mulheres de outro círculo, de outra classe social, Marta também será transposta para esta outra realidade. E novamente será através de uma figuração feminina, que Ihe servirá como equiparação, que seu lugar social relativo à classe é iluminado, questão que já vinha sendo incutida (intermediada) em Marta pelo posicionamento político de Gabriel.

Carlos Manuel, seu filho, é atingido por uma explosão em um episódio que remete à violenta atuação da polícia salazarista em resposta à Revolta Operária ocorrida na Marinha Grande em 1934. No entanto, ele não é a única vítima do episódio: também o é o filho de d. Joaquina, um operário de 18 anos que fazia parte do grupo rebelado. No entanto, se para Carlos o desfecho do episódio é a 
recuperação, para o filho de $\mathrm{D}$. Joaninha o final é trágico, pois fatal. Paira, a partir daqui, a dúvida em Marta acerca das causas que levaram a tal consequência (a que Gabriel chamava de injustiça) e, ainda que não elabore contundentemente o ocorrido, como fica claro enquanto acompanhamos a sua narrativa do episódio, no tocante à divagação acerca da possível morte do filho e a factual morte do outro, Marta age e consegue fazer com que nenhum operário seja demitido. No entanto, é diante da imagem de Joaquina (espelhada como mulher mais oprimida) que fixa a sua conclusão:

A história da pobre Joaquina é semelhante à de qualquer outra mulher de sua classe. A mesma sorte ínfima sem outros prazeres além daqueles que the dá a vida instintiva, e esses mesmos pagos e repagos em sofrimento, aflições, desespero. Não chega a ser mulher. É a fêmea que existe para que o homem procrie, é a carne voltada ao sacrifício com uma só lei: a submissão. Mocidade fugidia, breve estiolada por canseiras e privações, apaga-se, esquece-se de si, anula-se numa abnegação constante de que nem ela própria chega a ter consciência. (LAMAS, 2003, p. 126)

Aqui, como em Maria Luísa, é essa constatação da outra (no caso: a pobreza e cegueira lá, a pobreza e a perda aqui) que aponta para os privilégios da protagonista e que impulsiona a ação: tal qual a menina cega com Maria Luísa, Joaquina desperta Marta para outras opressões, ainda mais irretorquíveis que as suas, e a arremessa do estado ensimesmada para o mundo. Uma vez contraposta ao mundo externo, insurge o encaminhamento de seu desfecho. E mais uma vez temos aqui uma semelhança entre as estruturas narrativas dos dois romances que muito nos diz sobre as possibilidades de uma mulher na década de 1930, no Brasil e em Portugal: Marta, de certa maneira, liberta-se, ao nível do pensamento, mas não é saindo de seu casamento, pelo contrário, é através das possibilidades orquestradas por sua condição de mulher casada com um burguês.

Temos então novamente a condicionante paradoxal que não permite que a mulher atinja sua completa independência, no entanto, diferente da resignação observável em Maria Luísa, Marta se apropriará do dinheiro de seu marido para efetivar um projeto sob sua responsabilidade que afetará a vida de outras mulheres 
que trabalham na fábrica de Jorge. Evidentemente, é importante notarmos aqui também uma contradição edificada pela moral da caridade católica que visa a manutenção do sistema e que, por isso, não altera efetivamente o problema, servindo apenas como um atenuante: ao criar a creche para as crianças nas proximidades da fábrica, Marta, ao mesmo tempo em que liberta mulheres para que possam trabalhar, fomenta mais trabalhadoras para aumentar o lucro de seu marido. A contradição inerente à sua condição de classe fica assim exposta e vai ser negociada dialeticamente em uma sobreposição que denota opressão de gênero e opressão de classe. Há uma preocupação com a opressão referente à questão da mulher pobre que sobrevive em condições de trabalho ainda mais severas do que as de um homem, tendo em vista a obrigação da educação do filho que recai sobre si, além de sua dependência econômica, uma vez que o salário de uma mulher servia como complemento ao do marido. Sendo assim, através de certa ingenuidade exposta no discurso de Marta, o que podemos observar é que esse processo funciona mais como uma tentativa de facilitar a vida de outras mulheres, remetendo para aquela percepção coletiva configurada desde o início da narrativa, do que para o acirramento das diferenças de classe, mas isso, no entanto, aproxima Marta da ideologia burguesa que a constitui.

\section{O outro-homem como intermédio e a figuração do patriarcal}

Notemos o papel de intermediário que Gabriel exerce sobre Marta. A constituição narrativa através do ponto de vista de Marta irá revelar Gabriel, a princípio e até se enxergar emancipada, como uma espécie de intermediário entre ela e o mundo novo (a verdade para si) que se desnuda: se não era possível a ela a liberdade de observar o mundo através de outro ângulo, devido às condicionantes de sua vida, é Gabriel que irá possibilitar isso. Pode nos parecer fruto, esse curso do homem como intermediário, da mesma ideologia que buscamos aqui demonstrar que é contestada e, de certo, em partes, talvez o seja, o que gera o que já foi chamando de "ambiguidade" no romance. Isso porque aqui também irá operar a dialética que estrutura Maria Luísa, entre a ideologia patriarcal e a ideologia feminista que resulta em contestação da função social da mulher restringida à 
esposa e mãe ao mesmo tempo que não permite ruptura. Ou seja, aqui também ocorre, de certa forma, a contradição que organiza a manifestação do discurso narrativo, ainda que de maneira mais enfatizada, uma vez que Marta adquire uma reflexão ainda mais crítica que Maria Luísa. Essa movimentação não ocorre só no romance de Maria Lamas, mas também poderíamos encontrá-la na sua atuação como diretora do complemento feminino Modas \& Bordados, do jornal O Século, conforme nos alerta Mariline Rodrigues:

Poder-se-á dizer que a publicação possuía um caráter pluralista e democrático, pois, se por um lado difundia artigos adequados ao modelo de feminilidade que o regime defendia, por outro, nunca deixou de transmitir uma imagem de afirmação e dignificação da mulher, que sem contestar os valores tradicionais invocava a necessidade de outros, culturais e sociais que lhe conferiam maior presença e relevo na sociedade. (RODRIGUES, 2016, p. 62)

No entanto, é importante lembrarmos que aqui também estamos tratando de uma mulher nos anos 1930, e, neste caso, em contextualização portuguesa. Em Portugal, estava já instaurada à época a ditadura salazarista cuja base se organizava na tríade: Deus, Pátria, Família ${ }^{22}$. Nos anos 1930, acontece também o recrudescimento da política salazarista para as mulheres, com a concepção da volta das mulheres ao lar, tema que iremos tratar mais detalhadamente em nosso capítulo teórico. Portanto, a construção desse homem, que não é o marido, como intermediador para a percepção da vida que extrapola o que é conjecturado como condição para uma mulher neste contexto, em sendo resultado de uma escolha da narradora, é, em si, um posicionamento bastante insurgente (ainda que paradoxal quando além do seu contexto) na contestação da sociedade de ideologia patriarcal, na qual o marido retém a tutela da esposa.

Tal percurso de tomada de consciência acerca de sua possibilidade de atuação no mundo exterior ao núcleo familiar encaminha o desfecho de Para além do amor. No processo dialético, Marta alcança a sua independência, se não econômica, ao menos intelectual - ou, se preferirmos, conforme exposto em Maria

\footnotetext{
22 "Sob a cúpula da religião católica que tudo enformava, pretendia-se formar, por um lado, uma elite feminina com vocação de educar e servir socialmente, e criar, na "massa", o conceito da missão da mulher no lar. A "nova" mulher seria cristã, "moralmente sã", "portuguesa" ao serviço do Estado Novo no espaço próprio que lhe era reservado" (MADEIRA, 2007, p. 295).
} 
Luísa, ao nível da reflexão - e, assim, pode finalmente abrir mão de Gabriel como intermediário entre si e o mundo, em um reconhecimento próprio que prescinde do outro-homem. Abrindo mão de acompanhar Gabriel, Marta está, ao fim e ao cabo, firmando sua autonomia - não acompanhará Gabriel porque há algo de maior em que deve se ater: a possibilidade de construir com outras mulheres.

Paradoxalmente, ao não abandonar a sua condição, Marta não rompe com o casamento no qual pode, agora, entrever sua opressão. É possível observarmos, conforme tentamos expor, que o processo de certa emancipação não ocorre aqui também sem a contradição que lhe é inerente e, assim, podemos observar o movimento dialético que há na busca pela liberdade desta mulher a partir das condicionantes de sua classe, além de gênero. Marta, dessa forma, irá englobar em sua nova proposição sempre posicionamentos com eixos distintos, que só se equilibram à medida que destaquemos as possibilidades de ruptura em que operam. Assim, em um desses eixos, reassumirá para si o papel maternal exigido pelo conservadorismo da época de responsabilidade na educação do filho. No entanto, esse papel será inovador, quiçá subversivo, quando assume claramente que disputará a educação do filho com o marido:

Neste hora suprema em que o meu amor, a minha felicidade e a tranquilidade da minha consciência estão em jogo, Jorge não conta, a não ser para avigorar a minha ânsia de libertação... Encaro-o, apenas, como dono da fábrica onde trabalham os operários de quem me tornei solidária...

Não, não, Jorge é alguma coisa mais. É o pai de Carlos Manuel, o meu Carlos Manuel tão generoso, tão bom, que eu vou deixar inteiramente entregue à sua orientação, aos seus conselhos, à acção nefasta de seu exemplo aparentemente admirável.

Nunca encarara o problema sob este aspecto. Mas, é gravíssimo! Que vale a minha felicidade de mulher apaixonada, perante o meu dever de mãe consciente da responsabilidade que the cabe na formação do carácter e da alma do filho, perante, ainda, o direito adquirido já por todos aqueles que me deram a sua fé e esperaram confiadamente que a minha influência lhe seja benéfica? (LAMAS, 2003, p. 150-151) 
E em outro eixo, ainda que, sob certos aspectos, a creche tenha a função de acalmar a revolta dos operários, por "impedir que o protesto justíssimo dos oprimidos assuma proporções do hecatombe" (p. 151), também representa a possibilidade de construção de certa autonomia das mulheres dentro de um contexto determinado no qual Marta encontrou possibilidade de atuação e a isso, que nomeia "ideal da solidariedade humana" (p. 156), sacrifica seu romance com Gabriel.

Assim, ao se aproximar de Joaquina, depois de já ter se operado uma transformação em seu pensamento sobre suas possibilidades enquanto mulher, com a ajuda de Maria Clara, que surge em sua vida também com a intermediação de Gabriel, Marta vive a experiência de espalhamento nas outras que a fortalece como sujeita de suas próprias ações. Dessa forma, o que antes era uma sensação (todas as almas de mulheres), passa a corroborar certeza de que sua única possibilidade de se libertar está em se pensar socialmente (coletivamente) e, mais, em agir a partir de construção com as outras, atingindo algo além do que poderia ser oferecido por um homem ou um amor. Trata-se de um ensejo de perspectiva utópica de autonomia - a "felicidade do mundo", conforme podemos acompanhar na descrição que faz na sua carta de despedida enviada a Gabriel:

Há almas a que não bastará nunca a razão e a inteligência. Precisam de sonho, do infinito! A minha alma é assim. Não para limitar-me a uma felicidade egoísta, preciso da felicidade do mundo; mas como essa aspiração é irrealizável, contentar-me-ei dando a minha contribuição para a felicidade do pequeno mundo em que posso intervir. (LAMAS, 2003, p. 157)

Dessa forma, Marta, que agora afirma "não sou uma vítima, sou, mais do que nunca, uma revoltada" (p. 156), liberta-se também de seu intermediário, Gabriel, novamente, através da própria escolha (e de ações que possibilitam essa escolha). Não é o medo que the impede de viajar, mas o ensejo de ser útil para si e para as outras, além do papel de disputa em sua atuação como mãe. Encaminhado o desfecho do enredo dessa maneira, remete-nos para o que inicialmente apontamos nesta análise: partimos de Marta para avaliarmos a sociedade e é só através dela que são visitados os aspectos sociais. 
O foco narrativo em primeira pessoa - o que por si só caracteriza uma narradora -, portanto, trata, ele mesmo, de apontar para autonomia de escolha dessa mulher, que só vai se fortificando ao longo da narrativa até chegar ao seu cume que é abrir mão do seu amor (da intermediação de si com o mundo) para finalmente acessar o mundo por si mesma. Não é, certamente, sua independência total que está aqui declarada, mesmo porque, como Marta mesmo evidencia ao longo do romance, sua dependência econômica do marido é um fator determinante. No entanto, abranda-se aqui a necessidade do outro, afluindo um desejo de libertação que não pode mais ser retrocedido, sequer intermediado. Na contramão da resignação de Maria Luísa, ainda que limitada pelos mesmos litígios, Marta rebela-se, e em se rebelando encontra alguma autonomia.

\section{Um ponto de vista feminista: entre a ação e a resignação}

Elaboramos uma série de associação e dissociação entre dos dois romances até aqui analisados. No entanto, é fundamental nos concentrarmos no desfecho das narrativas porque, em última instância, é nele também que se atém a ideologia dessas narradoras após o processo de conscientização exposta nas narrativas. Temos que enquanto em Maria Luísa o destino da protagonista é a resignação, numa espécie de distopia que amalgama esse comportamento, uma vez que devolve Maria Luísa ao lugar da inação, em contraposição ao que antes correspondia a ação (austera), em Para além do amor, projeta-se Marta para a atividade na tentativa de consolidação de sua nova proposição, agora engajada ao projeto de disputar a educação do filho com o marido e na construção com outras mulheres, também de outras classes. É inegável que temos, em ambos desfechos, reflexos da ideologia patriarcal, assim como devemos admitir que ela se caracteriza diferentemente nas duas narrativas e, parece-nos, isso corresponde a certa ideologia feminista presente nessas vozes narrativas.

Maria Luísa resigna-se ao seu papel de esposa e mãe, perdendo ainda nele a dimensão de autoridade que exercia antes. A autora implícita parece apontar, desta maneira, para a intrínseca relação indissolúvel entre o novo e o antigo paradigma. Com esta escolha, germina na narrativa um caminho só tangível através da 
conciliação, que não reverbera ação senão em inação. Maria Luísa adquire consciência da sua condição de gênero, depois do adultério que lhe faz romper com a estrutura que delimitava sua autoridade ancorada na sistematização de certa ordem, no entanto, isso também faz com que volte ao lar resignadamente, para dar continuidade à sua função de esposa e mãe, que continuará sendo exclusiva. Tratase, dentro dos moldes, de uma mentalidade modernizada pela desigualdade, que assume certa consciência de sua condição social enquanto não propulsiona outra coisa que não a submissão ao seu destino. Então não temos em seu processo de conscientização uma força motriz que a mobiliza na conquista de certa autonomia, pelo contrário, a narrativa delimita a sua consciência a novos posicionamentos assumindo apenas as mesmas funções. Assim sendo, a autora implícita define que a mulher entre esses dois paradigmas deve necessariamente continuar exercendo suas funções definidas como primordiais por aquela sociedade, sabendo-se, no entanto, imperfeita e sem autoridade. Parece-nos, este, um desfecho distópico.

Em contraposição, ainda que também opte por sua função de esposa e mãe, Marta encontrará na atividade com a creche que acompanha a instalação na fábrica de Jorge o trabalho que aponta para uma ação. Com o trabalho, acaba por responder às demandas do viés de certo feminismo português das primeiras décadas do século. Mais do que defender o sufragismo, o feminismo ao qual parece responder o projeto romanesco de Maria Lamas, ainda que esta negue até determinado momento a sua atuação feminista, aponta para uma renovação no papel das mulheres, que reverbera a necessidade de conscientização das mulheres em suas funções sociais assim como a necessidade de acesso a uma independência, sem, no entanto, abandonar o seu papel na família. Marta, ao longo da narrativa, assume, principalmente através do reflexo de Maria Clara, maior representação no romance desta nova mulher vinculada aos moldes feministas, com uma maior consciência acerca das condicionantes de sua vida que lhe permite ampliar o horizonte privado no qual estava submersa até conhecer Gabriel. Se com sua conscientização vai atingindo novos graus de instrução, por outro lado também dota-se de alguma independência numa construção possível, ao lado de outras mulheres, com as contradições inerentes a sua posição de mulher burguesa, através do trabalho.

João Esteves, ao analisar a APF (Associação de Propaganda Feminista) em Portugal, pontua: 
O trabalho feminino não representava somente a garantia de maior igualdade no casamento, mas a própria sobrevivência económica das mulheres, atendendo a que, segundo o apuramento do censo então realizado, elas eram em muito maior número do que os homens e nem todas podiam aspirar ao papel de esposas e mães. A diferença numérica era a melhor resposta "àqueles que não querem que a mulher ocupe lugares remunerados", transformando-se num poderoso argumento para contrariar todos os que se proclamavam anti-feminista. (ESTEVES, 1998, p. 87)

Desta forma, a autora implícita de Para além do amor radicaliza este pressuposto, ao projetar como sua narradora uma mulher já esposa e mãe, que correspondia aos modelos sociais marcados por uma ideologia patriarcal, para a insubordinação através do trabalho. Marta não desafia Jorge apenas na disputa pela educação de seu filho, mas se insurgindo também, de certa forma, no ambiente fabril, lugar até então de exclusivo domínio dele, no qual declara estar ao lado dos operários e onde exercerá trabalho vinculado às operárias. Aponta-nos, assim, para uma contestação que corresponde à autonomia possibilitada por dada conscientização que atingiu sobre sua condição de mulher. 
CAPÍTULO II: Amanhecer e A Ilha Verde 


\section{Amanhecer, de Lúcia Miguel Pereira}

Amanhecer, de Lúcia Miguel Pereira, foi publicado em 1938, exatos cinco anos depois de Maria Luísa. Mantém-se aqui a mulher como protagonista, mas o romance traz uma narradora em primeira pessoa, assim como em Para além do amor. Em Amanhecer, Maria Aparecida, uma mulher jovem crescida no interior do Rio de Janeiro, filha de um pai herdeiro, que perde tudo, e de uma mãe pobre, irá contar a sua história de vida nos momentos antecedentes à sua decisão de viver um amor fora da ordem do casamento.

Vivendo em São José, pacato interior do Rio de Janeiro, onde seu maior passatempo é visitar a Casa Verde, na qual ocorreu uma morte resultante do que Maria Aparecida imagina ter sido uma história de amor com final infeliz, ela vê sua vida modificada pela chegada de novos moradores da casa, a família da capital. Vêm para as férias de verão a mãe, o pai e a filha, Sônia. Além disso, recebem a visita do sobrinho Antônio, que se hospeda um tempo na casa dos tios, fugindo das más companhias, que saberemos em breve tratar-se de militantes comunistas.

Já no primeiro capítulo do romance, fica marcado o lugar social ao qual pertence Maria Aparecida. Filha de um pai que foi herdeiro de homem rico ("Meu avô Lobato tinha sido um homem abastado", p. 277), mas cujo foco não é o trabalho para acúmulo de capital, a família de Maria Aparecida vive de maneira modesta em São José, depois de muito tentarem em outros lugares.

Eu não conheço detalhadamente a história das maluquices de papai. Só sei que, quando tio Afonso se formou, meu avô deu aos três filhos dinheiro para se estabelecerem. Os outros dois compraram casas no Rio, as casas onde ainda moram, no Andaraí. Papai, que já tinha andando em quatro ou cinco empregos, quis ser agricultor e comprou um sítio em Mendes, para plantar verduras. Aí é que conheceu mamãe, cujo pai era agente de estação. A família de mamãe era mais modesta que a de papai, e creio que esta incluiu o casamento entre as "maluquices de Juca". Mas era uma grande injustiça. Mamãe pode ter tido suas implicâncias, mas foi uma boa mulher. (PEREIRA, 2006, p. 277) 
Apesar de não configurarem, como a família que aluga a casa verde, uma família da elite econômica, sendo pobres, também não são parte da camada mais pobre local, que ficará marcada na narrativa pela presença de personagens negras que prestam serviços, na maior parte da vezes, domésticos, e cujos destinos serão, vias de regras, trágicos (Luiza, que engravida e é abandonada pelo pai do filho; Joaquim, que comete suicídio; Manuel Firme, que na prisão a mando de Raul, irá morrer doente). O lugar da narradora, portanto, não é o mesmo ambiente burguês no qual estava Maria Luísa, ainda que isso seja, a princípio, o que Aparecida almeja na primeira parte da narrativa (ainda que também não o seja da camada mais pobre do vilarejo, já que sua casa era segunda maior de São José). Se em termos de classe, Maria Aparecida se apresenta assim distante tanto de Maria Luísa como de Marta, na questão de gênero seu lugar social também terá as marcas da ideologia patriarcal que ficarão evidenciadas desde o início da narrativa, principalmente através da dominação que o pai exerce sobre a mãe, a qual será revelada de saída por Tia Josefina.

A maneira de projetar este lugar social, no entanto, difere-se da forma como sucede em Maria Luísa. Se lá uma narradora abaliza uma visão patriarcal e burguesa que irá se sobrepor a Maria Luísa logo na primeira página da narrativa, conforme buscamos esclarecer, aqui temos contato, através da voz em primeira pessoa, tal qual em Para além do amor, com uma personagem que contesta seu lugar social, projetando na chegada de novos moradores da Casa Verde a possibilidade de resolver a sua enorme insatisfação em morar em São José e ser parte de uma família modesta, como atesta a própria narradora ao imaginar a sua primeira conversa com a filha do casal recém chegado: “- Como é que, bonita como você é, pode viver neste buraco?" (p. 271). O que alude, desde o início, à ambição da protagonista-narradora em sair do espaço físico e também social em que se encontra.

Além deste lugar social em que está incluída Maria Aparecida e, portanto, a narradora, é importante apontar que em diversas passagens ela fará menção ao tempo que narra como sendo um tempo diferente do tempo em que está, aloca-se, muitas vezes, num tempo presente contando fatos do passado, que saberemos se tratar de dois anos antes, quando conheceu Antônio. Essa localização temporal é tão importante que o início da narrativa se faz através dele: "Lembro-me tão bem daquele dia..." (p. 271). 
A importância de frisar isso incide na diferença que há entre a moça de 18 anos que vive os eventos narrados e a outra, que narra, entre a protagonista da trama que se passa no passado e a narradora do presente. Assim como em Maria Luísa, aqui ocorre uma transição entre a personagem nas duas partes da narrativa, no entanto, se lá, como buscamos apontar, isso acontece na protagonista e na narradora, concomitantemente, aqui o mesmo sucederá, uma vez que a protagonista é a narradora, após viver sua transformação. Segundo Luís Bueno:

A Aparecida que vive a trama como personagem é um ser em transição, que alimenta ainda certas esperanças e certas crenças. Mas a que narra, transposta toda sua trajetória, está jogada na mais absoluta desesperança. (BUENO, 2006, p. 516).

Incide sobre Maria Aparecida, de alguma forma, o mesmo caráter de resignação aos fatos como em Maria Luísa, mas se nesta isso se apresenta na abnegação principalmente àquilo que havia consolidado enquanto consciência de sua condição de mulher, em Aparecida isso será configurado por uma total manutenção desta consciência que não tem como resultado final a resignação, mas sim a renúncia. Maria Aparecida vivendo a sua relação com Antônio, a quem vê-se enredada, renuncia ao status de mulher casada e por isso paga um alto preço, que é sua vida marginal diante da sociedade que exige o casamento com condição fundamental para a vida da mulher. Aparecida não será, como Maria Luísa, a personificação do modelo esposa e mãe, mas, pelo contrário, será o inverso disso, e, ao exercer o amor livre do estatuto do casamento, torna-se uma mulher marginal, porque não dentro dos padrões socais impostos à mulher.

Assim, socialmente marginalizada, há também em Maria Aparecida o predomínio da desesperança, conforme a narradora nos evidencia frequentemente, fazendo intervenções do presente nos fatos contados no passado, para escancarar suas frustrações: "Essa cena me fazia sofrer, mas eu me comprazia em evocá-la. E se não me figuravam outros pormenores, era apenas porque eu ignorava quase completamente, naquele tempo - e não há muito mais de um ano..., - os gestos do amor" (p. 296). Portanto, diferentemente do que ocorre em Para além do amor, a narradora de Amanhecer não toma consciência dos fatos que narra concomitantemente no passado e no presente, apresentando um processo de 
conscientização que sofre nessa elaboração, mas trata-se de uma narradora que no presente observa o seu passado e que conta sua história com a intenção de avaliar sua trajetória que, ao longo da narrativa, e não apenas no final, apresenta com perspectiva negativa.

A perspectiva negativa é assegurada pela crítica que faz a Antônio ou, antes, a crítica que faz a si mesma por ter acreditado, de certa forma, nos ideais libertários de Antônio que, como veremos ao longo da narrativa, se revelarão falsos, pelo menos no tocante a função social da mulher. Temos, portanto, que a narradora, que obviamente conduz a leitura para o seu próprio ponto de vista, precipita as consequências dos fatos narrados, uma vez que, aqui também como em Maria Luísa, os seus comentários vêm antecipar na narrativa seu próprio desfecho, que julga infeliz. Desta maneira, ainda que haja os diferenciais importantes que determinam uma narrativa sob o foco de primeira ou terceira pessoa, como ocorre nesses dois romances de Lúcia Miguel Pereira, a narradora tecerá, através de seus comentários, uma antecipada avaliação da ação.

Acerca dos romances anteriormente analisado, Amanhecer apresentará outras linhas convergentes, uma vez que aqui também existem outras personagens, mulheres, que desvendarão certa perspectiva da narradora. Além disso, a questão do trabalho se faz presente em Amanhecer tanto quanto em Para além do amor. Nesse sentido, enquanto em Marta o papel do trabalho é central na elaboração de uma maior autonomia, ainda que não infira uma independência econômica, em Maria Aparecida ele não aparece senão como fator secundário, mesmo apontando para certa independência econômica. Talvez por isso, distintos sejam também os destinos dessas duas protagonistas. Enquanto Marta decide não seguir o seu amor em prol das atividades que esboçam certa emancipação, Maria Aparecida, apesar do trabalho que lhe imputa emancipação com relação à vida que tinha em São José, resigna-se à passividade da espera em conformidade com a restrição que sua escolha ocasiona na sociedade de ideologia patriarcal que para si aponta como destino o casamento.

Ainda frisamos que, na segunda fase do romance, quando sai de São José para a cidade do Rio de Janeiro, incide sobre a protagonista tantos as condicionantes sociais de gênero quanto as de classe. Configuram-se sob seu olhar e sua narrativa confessional tais aspectos aprisionadores que serão responsáveis pela a frustração e, também aqui, certa resignação, porque, embora sua trajetória 
em tudo seja diferente de Maria Luísa, também o seu desfecho não será feliz, senão frustrado por uma ausência de alternativa que é incapaz de vislumbrar.

\section{A orquestração do espectro feminino: a tríade aqui como a tríade de lá}

Antes da chegada da família de Sônia na Casa Verde, Maria Aparecida mantinha uma relação com a morta da Casa Verde que, junto a Nossa Senhora Aparecida em quem está espelhada no aspecto místico, era responsável pelo que ela chamava de sua proteção. Então no início de sua narrativa, ela irá nos esclarecer quem é esta morta que irá, também ela, a partir do viés tecido por Maria Aparecida, a narradora em primeira pessoa, ser parte do mosaico feminino que emoldurará a narrativa. Este mosaico, para além da narradora que em Amanhecer como em Maria Luísa também irá se elaborando a partir de outras personagens, será formado por Sônia (seu reflexo invertido), Dona Laura (mãe de Aparecida) e a morta da Casa Verde. Destaquemos, porém, que a morta da Casa Verde é uma personagem imaginada em detalhes por Maria Aparecida, o que configurará, em última instância, o que consideraremos como o lugar de certa consciência reflexiva de Aparecida. Essas três personagens serão sempre parte da conformação de Maria Aparecida, que também vai se estabelecendo em contraposição a elas, assim como em Maria Luísa. À diferença de lá, no entanto, aqui não há uma narradora observadora que tece seu diagnóstico sobre a protagonista de maneira aproximada ou distanciada, porque aqui a protagonista, como Marta, irá trazer para a narrativa a sua própria impressão de verdade, o que tangencia a contraposição a seu ponto de vista.

No entanto, é fundamental que percebamos que também aqui irá ocorrer a composição em tríade da condição da mulher que foi apontada em Maria Luísa. Amanhecer apresenta, dessa forma, Dona Laura como o paradigma do passado e Sônia como paradigma do novo (moderno) no que tange a condição de mulher a partir do olhar da narradora, conforme buscaremos apresentar; como em Maria Luísa, com um diferencial fundamental: se lá isto estava respaldado pela questão de gênero, a mulher em seu posicionamento social mais progressistas e mais retrógrado (na ordem da sociedade de ideologia patriarcal), aqui também isso será 
transpassado pela questão de classe, interseccionada com a questão de gênero. Assim sendo, Sônia será a representação da mulher burguesa moderna, parte de uma família da elite econômica do Rio de Janeiro, enquanto D. Laura será a representação da mulher pobre, dependente e submissa ao marido, que segue os preceitos que lhe são imputados por uma sociedade de mentalidade patriarcal e classista. O locus enunciativo de Maria Aparecida se dará, porém, exatamente neste ínterim entre uma coisa e outra; apesar de pobre, Maria Aparecida tem acesso à instrução a que outras meninas (da elite) tiveram acesso. E é a partir dessa instrução que se afasta da mãe enquanto busca ambiciosamente uma ascensão social (que a faria sair daquele do "buraco onde vive").

Na contramão disso, será a partir da experiência da mãe que também Maria Aparecida conseguirá ascender a um determinado grau de conscientização maior do que Sônia alcança ao longo da narrativa, a partir do que expõe a narradora. Isso porque uma vez fomentada em sua consciência as diferenças entre as classes que permeiam e ponderam sua condição, Maria Aparecida não conseguirá mais recorrer, como Sônia, a uma força superior, mística, muito embora manifeste este como sendo o seu desejo em algumas passagens narradas do presente, ou seja, do tempo em que já viveu a transformação e, portanto, seu processo de conscientização sobre sua condição de mulher pobre. A partir de sua conscientização, o misticismo será sumariamente recalcado, para depois se transformar em impossibilidade. Desta forma, enquanto a solução para a crise de Sônia é se tornar freira, em alternativa ao casamento, mas cujo destino Maria Aparecida entende como infeliz, porque incompleto, a narradora irá reconhecer o seu próprio com os mesmos fatores condicionantes, o que remete à impossibilidade de realização de uma liberdade total, tanto por parte de uma quanto por parte de outra.

Sônia, muito embora durante um longo período narrativo represente o espectro da mulher moderna de certa maneira emancipada, em relação à desenvoltura com a qual fomenta alguns temas tabus para Maria Aparecida, como a questão sexual, irá, depois de uma experiência de aborto, recorrer ao enclausuramento religioso. Sônia escapa de seu destino ao casamento, assim como tia Josefina, personagem secundária que aparece no início do romance através da religião. Tal evento remete-nos a análise de Maria José Rosado Nunes acerca da história das freiras do Brasil. No final do século XIX e início do XX, as freiras se 
encarregavam de tarefas necessárias à sociedade, como a que Sônia exercerá nos cuidados à saúde que se dedicará quando finalmente torna-se freira, no entanto, havia ainda um histórico recente acerca da escolha dessas mulheres:

Os conventos e recolhimentos não foram apenas espaços de submissão. As mulheres também os utilizaram a seu próprio favor em muitas situações: para escapar de um casamento não desejado refugiadas no claustro, pediam o divórcio de maridos que as maltratavam fisicamente ou dissipavam sua herança. As casas religiosas foram ainda, por muito tempo, um dos poucos lugares em que as mulheres aprendiam a ler e escrever. (NUNES, 2017, p. 488)

É importante observar que a renúncia ao casamento é coincidente nas duas principais personagens do romance, o que cada uma faz ao seu modo invertendo, ao final da narrativa, as perspectivas iniciais: transforma-se Maria Aparecida, aproximando-se de certa mentalidade ateísta, incapaz de se mover como antes quando crente na força de proteção em Nossa Senhora Aparecida ou na morta da Casa Verde, por um lado, e Sônia se entrega a uma devoção religiosa oposta à sua descrença inicial, por outro. Para Aparecida, essa transformação, ainda que implique em novas problemáticas (enfrentar a realidade sem apelar às forças místicas), foi um caminho sem volta, como evidencia:

Tudo aquilo em que eu acreditara antigamente não representava para mim mais do que um montão de trapos. Hoje não ousaria dizer o mesmo, embora não possa - nem queira - voltar atrás. (PEREIRA, 2006, p. 339)

A inversão, no entanto, fica exposta pela narradora que se imputa, agora, superioridade com relação à Sônia: "E senti também uma sensação de superioridade. No princípio, quando Sônia chegou em São José, parecia-me ser uma criança junto dela; agora, era ela a criança" (p. 327). Embora haja a inversão de papéis no que parece ser a postura com a qual essas personagens se colocam diante da consciência que adquirem com a experiência e a reflexão a partir de suas condições de mulheres, o desfecho das duas personagens é coincidente na visão 
da narradora, uma vez que esta não vislumbra melhor destino do que o seu imerso em frustração para a Sônia: "Não me diz nada, mas creio que teve uma decepção; a vida de enfermeira, que leva, não deve ter correspondido aos arroubos místicos que a fizeram abandonar o mundo" (p. 367). Ambas as personagens sofrem essas transformações a partir do contato que têm com Antônio, o que estabelece mais um elo importante entre essas figuras do romance. E se Sônia observa em si as mudanças que sofreu, também observa isso em Maria Aparecida, conforme a alerta:

- Você está repetindo Antônio, que pensa que todas as leis morais são preconceituosas... Mas diga-me, você também não renunciou a seus sonhos? Você era muito diferente quando nos conhecemos, antes da chegada de Antônio. (PEREIRA, 2006, p. 338)

Como terceiro elemento dessa tríade, Laura, a mãe de Maria Aparecida, estará aqui aportada com o mesmo papel exercido por D. Constança, em Maria Luísa. O embate de gerações - mãe e filha - fica configurado no pensamento conservador que em geral transversa as diferenças comportamentais. Em Maria Luísa isso ficava exposto, principalmente, por uma postura de submissão de D. Constança com relação ao marido, postura esta que não tinha a filha com relação ao seu marido. A postura submissa também estará presente em Laura, com relação a Juca, durante boa parte do desenvolvimento narrativo, até entendermos, após a morte do pai de Maria Aparecida, a que tipo de opressão estava exposta a mãe e os motivos dessa opressão. Muito embora em Maria Luísa a ironia da narradora evidencie que $D$. Constança apenas aceita fazer o seu papel social e que, de alguma maneira, tem algum nível de consciência sobre ele ao fingir interesse, por exemplo, pelas questões do genro para suprir uma ausência de interesse que condena na filha, essa faceta não fica tão clara como agora em Amanhecer. Sendo a narradora Maria Aparecida, ainda que ela aja com revolta às confissões da mãe que lhe questiona o comportamento, isso é elaborado de tal maneira que o discurso da mãe sobre a vida conjugal que experimentou fica em destaque. Isso porque a narradora, uma Maria Aparecida transformada, que agora observa os fatos do passado, é capaz de dar maior relevância ao que conta a mãe do que à revolta que sentiu com tal conversa, quando ainda estava vivenciando o processo da transformação que sofreu. 
Temos, portanto, algumas semelhanças entre Laura e D. Constança principalmente em relação à perspectiva da narradora. Ambas as narradoras se posicionam no sentido de revelar que, muito embora tenham essas personagens obedecido às ordens sociais, postas em xeque agora pelo comportamento de suas filhas, ainda assim elas não estavam completamente alienadas das condições que Ihes eram impostas. Representam assim um passado, mas, no entanto, um passado que também elas, mais pela forma em que se deixam entrever do que pela ação que apresentam no desenvolvimento narrativo, questionam. Veremos a seguir nesta análise a incidência da opressão patriarcal em Laura. Entretanto, é significativo que aqui também ocorra uma identificação maior entre mãe e filha, assim como pudemos verificar na segunda parte da narrativa de Maria Luísa. Desde o início, a narradora aponta para essa proximidade em suas colocações com relação à mãe, como, por exemplo, quando defende a figura da mãe diante do possível juízo que faz a família do pai desse casamento: "Mamãe pode ter tido suas implicâncias, mas foi sempre uma boa mulher" (p. 277).

Nesta tríade com Sônia e Laura, ficará assegurada a transformação que se passa em Maria Aparecida e, ao final da narrativa, podemos também perceber que há nela uma conscientização das semelhanças das condições que operam em sua vida com as condições de vida dessas duas mulheres. Se seu destino está identificado ao de Sônia pela frustração, também o estará ao da mãe, pela submissão que define sua relação com Antônio. Há, portanto, na narradora na fase presente um adensamento dessa conjunção que expõe nas entrelinhas, enquanto conta os eventos do passado.

Apesar de não entendermos que figurem aqui como parte dessa tríade tal como se estabelece em Maria Luísa, há ao menos mais duas personagens importantes nesta configuração. A primeira, é a Morta da Casa Verde, cuja presença ocorre principalmente através da imaginação de Maria Aparecida, tangenciando os seus condicionamentos sociais. A morta parece exercer o papel de manter a Maria Aparecida que narra ainda em contato com a Maria Aparecida que vivenciou os fatos, no sentido de lhe lembrar principalmente os seus desejos de "mulher comum", que a narradora esclarecerá que estão perdidos a partir do momento em que passa a viver com Antônio no Rio de Janeiro. A morta assim representará, por exemplo, o sonho do amor romântico da narrativa, e não à toa está logo nas páginas iniciais de Amanhecer o que Maria Aparecida imagina sobre a misteriosa morte da morta: 
Esse fato, que ouvi narrar inúmeras vezes, com pequenas variantes, me dançava na cabeça, vivia na minha imaginação. Na verdade, esse drama de gente que não conheci foi, até a chegada dos novos habitantes da Casa Verde, a coisa mais importante da minha vida.

(...)

Ficava horas a impregnar-me desse ambiente estranho, acabava por me confundir com a heroína do drama. Para mim, a história era simples: a moça gostara do enteado, antes de se casar. Por qualquer motivo brigaram, e ela aceitou um casamento de conveniência, sem saber que o pretendente era justamente o pai do namorado. História inverossímil, mas que me parecia a única possível. (PEREIRA, 2006, p. 273)

A morta entre na história, assim, carregada do que lhe atribui Maria Aparecida. A parte da história contada que é de conhecimento do povoado aponta para um casamento de clausura, como sabemos no entrecho imediatamente anterior a este, mas o que fica destacado pela narradora é a sua própria imaginação de um amor romântico. Tal premissa não será quebrada pela narradora diretamente em uma avaliação crítica que lhe transforma essa imaginação, mas o será por uma estrutura narrativa que aponta aqui também problemas com relação ao casamento, já que a morta era vítima de uma "gaiola dourada" (p. 273). Por isso, de alguma maneira, a morta da Casa Verde, assim como Sônia e Laura, e assim como veremos a seguir em tia Josefina, operam de maneira a romper certos paradigmas em Aparecida, que, uma vez rompidos, passam a ajudá-la a observar o mundo através de uma espécie de lupa que acreditamos pautada por certo feminismo possível na época, ainda que seu destino esteja ressarcido pelo conservadorismo operante na sociedade. Se a morta exerce o papel de manutenção do amor romântico, tia Josefina terá participação exatamente contrária.

Apesar de seu papel secundário, tia Josefina tem suma importância para a formação intelectual de Maria Aparecida, já que a educação da sobrinha dependeu dela, que era freira e trabalhava num colégio de meninas. Devido a isso, Maria Aparecida tem ingresso ao universo educacional só possível para meninas ricas, o que lhe garantirá certo grau de instrução que, mais tarde, impulsionará suas reflexões e seu acesso ao mundo do trabalho. Maria Aparecida, através da atuação 
da tia, adquire acesso àquilo que era muito caro ao debate feminista das primeiras décadas dos anos XX: a educação. Além disso, também através de tia Josefina, Maria Aparecida terá o primeiro impulso à sua independência:

- Você precisa estudar muito, Aparecida, pois há de ter que ganhar sua vida; seu pai, com as maluquices dele, não vai deixar nem um vintém. Deus ainda teve pena de sua mãe, dando-lhe só uma filha. (PEREIRA, 2006, p. 277)

Em contraste com esse mosaico da figuração feminina, teremos o contato com o espectro patriarcal que se amparará, principalmente, nas ações das personagens masculinas. Torna-se relevante que nos voltemos para ele para prosseguir a análise.

\section{A configuração patriarcal na presença masculina em Amanhecer}

Ocorre que há uma diferença fundamental na configuração do patriarca desses romances. Tanto em Maria Luísa quanto em Para além do amor, o patriarcal está representado na elaboração estrutural dos romances pelos maridos, sendo Jorge sua representação mais grosseira e Artur a figuração daquilo que vinha sendo um abrandamento da agressividade patriarcal, imposta pela nova sociedade burguesa brasileira que está em conformação nos anos 1930, conforme procuramos apontar na análise. Em Amanhecer essa configuração estará apresentada pela narradora através de duas figuras a si ligadas, bastante contraditórias, porque, aos moldes de Artur de Maria Luísa, apresentarão características que abrandam suas perspectivas patriarcais, que serão expostas de acordo com o adensamento do processo reflexivo sobre a condição da mulher da protagonista-narradora, orquestrado por uma autora implícita que manipula os fatos que corroboram tal adensamento.

Comecemos pela figura do pai. A narradora desenvolve então a descrição dessa personagem de maneira que suas características serão reveladas ao longo da narrativa e não temos, assim, desde o início, a configuração de seu caráter 
autoritário. A partir de sua morte, no entanto, a autora implícita organiza na voz narrativa uma sequência de diálogo entre Maria Aparecida e a mãe que será revelada sob a perspectiva da narradora, mas que esclarecerá a faceta opressora de Juca, que se com a filha não se apresentava tão nítida, com a mãe era escancarada. Na perspectiva de Maria Aparecida, a configuração autoritária do pai vai se apresentando de maneira mais lenta, uma vez que Juca, a princípio, pareceIhe ter menor relevância. Considerado um "maluco" por sua família de elite, Juca perde praticamente todo o dinheiro que herdou de seu pai em investimentos nos quais nunca trabalhou com afinco, conforme a narradora nos revela:

Papai explicava pela pouca sorte os seus prejuízos; um sítio era muito castigado pela saúva, o outro não tinha água, noutro o transporte caro consumia todos os lucros... Sempre arranjava um pretexto para acabar vendendo. (PEREIRA, 2006, 277-278)

A relação de poder de decisão do pai para com a filha fica exposta desde o primeiro capítulo, uma vez que os pais the proíbem o primeiro sonho de emancipação: trabalhar como datilógrafa no Rio de Janeiro. A mãe pelo medo de que ela se tornasse uma mãe solteira, o pai porque para ele seria uma humilhação parecer aos outros que não poderia sustentar a filha. "Mas quando terminei o curso e falei do meu projeto, papai e mamãe ficaram horrorizados" (p. 277). Se é verdade que este impedimento também ocorreu devido ao posicionamento da mãe, como após a morte do pai Maria Aparecida tem o consentimento da mãe para seguir para o Rio de Janeiro com a desculpa de trabalhar para o dr. Maia, evidenciado fica que tal impedimento inicial aponta mais para a autoridade do pai, do que para a da mãe.

No entanto, o primeiro embate de fato entre pai e filha ocorre através de Sônia, ainda que seja, mais uma vez, de maneira sutil. Com o argumento de que recebeu uma mensagem dos espíritos, Juca tenta mesmo afastar a filha de Sônia, a quem via como perigo, usando, para tanto, o mito da morta da Casa Verde já conformado na perspectiva de Aparecida. Todavia, nesta passagem podemos verificar que, embora se evidencie o distanciamento entre entre pai e filha, conforme nos esclarece a narradora, também se nota a influência que o pai exerce sobre ela: 
Foi a única vez que papai mostrou interessar-se por mim. Vivia como se nem percebesse a minha presença. $\mathrm{E}$ eu, vendo-o tão gordo, tão suarento, o dia todo matando formiga na chácara e cuidando das plantas, sempre cochilando na cadeira de balanço quando estava dentro de casa, custava a crer que se preocupasse com os espíritos. Sabia que frequentava o Centro Espírita, mas não dera ao fato grande importância. E agora descobria nele uma vida que não tinha nada a ver com a de todos os dias. Uma alma. Senti-o habitante de um mundo misterioso (...). Cumpriu a promessa. Nunca mais tocou no assunto. Às vezes, eu pensava até que tinha sonhado aquela conversa. Mas nem por isso ela me impressionou menos. Tinha a sensação de presenças invisíveis em torno de mim. De forças ocultas, que me empurravam. Senti-me espreitada, vigiada. (PEREIRA, 2006, P. 286)

Como podemos observar, ainda que Aparecida mantenha alguma independência de opinião com relação ao pai, ele exerce sobre si uma influência bastante significativa que será iluminada pela mãe. O autoritarismo de Juca ficará de fato marcado sobre a mãe, sua esposa, a quem impõe total submissão e de quem, inclusive, afasta a própria filha. E nesse sentido, apesar das diferenças de configurações do patriarcal nesta protagonista, Amanhecer mantém também como questão central da problemática, de novo, a figura do marido. Isso ficaremos sabendo depois da morte do pai de Aparecida na narrativa, quando Laura, finalmente livre de Juca, revela à filha a sua história infeliz de mulher casada, já parcialmente antecipada à narradora por tia Josefina. Ressaltamos que isso só será feito porque Laura entende que Antônio representa para a filha o mesmo lugar de opressão que o marido exerceu sobre si, e podemos observar em sua análise acerca disso dois eixos centrais: 1. a questão de gênero vinculada à ideologia patriarcal; 2. a questão de classe.

- Os homens são incompreensíveis... Juca parecia me desprezar porque... pelo que nós tínhamos feito. Casou contra a vontade. Tratava-me quase como uma criada. Responsabilizava-me por tudo o que acontecia de ruim, tinha vergonha de mim, não queria me apresentar à família dele. E eu, que podia fazer? Baixava a cabeça, 
aturava tudo; ainda tinha que lhe ser grata porque o casamento me livrou da desonra. Depois que nos casamos, vivemos como dois estranhos. Eu era moça e não era feia; pois ele nunca mais viu em mim uma mulher, a mulher dele. Você é bastante sabida para entender o que quero dizer. No princípio senti muito, depois me habituei. A gente se habitua a tudo nesta vida, até a ser humilhada dia e noite dentro de casa. Só me revoltei quando ele começou a separar você de mim, a ensinar a minha filha a me desprezar. (PEREIRA, 2006, p. 332)

O que temos então é a autoridade de Juca sobre Laura expondo os lugares de opressão e humilhação ao qual esteve exposta dentro de seu casamento. Para tentar proteger a filha, como a narradora revela na continuidade deste mesmo diálogo, a mãe tece uma angustiada narrativa sobre seu passado. Não há em Maria Aparecida nenhuma desconfiança ao relato da mãe com relação ao pai, apesar da resistência da filha em concordar com os sentimentos da mãe que the atribui também o desprezo em atitude semelhante ao (e diligenciada pelo) pai:

Eu quis responder, dizer que aquilo tudo era injusto, absurdo. E era mesmo. Eu não tinha de fato grande afinidade com mamãe. Mas não a desprezava. Ao contrário. Até gostava muito mais dela do que de papai, e às vezes tinha remorsos de não ser mais carinhosa. (PEREIRA, 2006, p. 333)

Se por um lado temos essa configuração do modelo que revela a ideologia patriarcal através de Juca principalmente no que tange o seu posicionamento enquanto marido opressor, por outro teremos um cenário complexo e contraditório a partir do que se vai tecendo com Antônio, condensado pela narradora que conta a sua história em primeira pessoa apontando, simultaneamente, para a consciência que Antônio desperta em si e a opressão que sua figura exerce sobre si.

Se na relação que é tecida entre a protagonista e a narradora de Maria Luísa a figura masculina tem papel secundário, em Amanhecer sucederá justamente o contrário. Sob a perspectiva de Aparecida, assim como em Marta de Para além do amor, a figura masculina tem uma projeção significativa porque aqui também terá participação em um processo de emancipação, como podemos intuir desde o início 
desse encontro: "Antônio falava pouco, mas tudo o que dizia me encantava. $\mathrm{Na}$ verdade, Antônio foi o primeiro rapaz com quem convivi" (p. 293). No entanto, se Marta atinge uma emancipação a partir de sua ruptura com este amor ideal, aqui Aparecida irá conseguir observar as amarras também de sua condição de mulher a partir de sua opção por prosseguir com Antônio, o que lhe imputa sérias condicionantes sociais, se não como esposa, como mulher que vive uma relação fora da ordem do casamento.

Antônio, sendo assim, toma posicionamento em certa medida parecido com Gabriel em Para além do amor, principalmente no que concerne aos ideais de cunho progressistas que visavam uma sociedade mais justa. Ele, então, é responsável por apresentar à Aparecida muitas questões relacionadas à opressão de classe e de gênero que lhe são incutidas pela sociedade em que vivem. $O$ processo de transformação pelo qual passa Aparecida será facilitado por seu relacionamento com Antônio, mas mais do que isso: pela influência que Antônio exerce em sua construção reflexiva (e intelectual, portanto) a partir do encontro dos dois. Assim fica marcada a contradição que será apresentada pela narradora nessa figura, uma vez que será ele, ao mesmo tempo, responsável pelo seu aprisionamento numa vida marginal (dentro das imposições daquela sociedade), porque excluída a possibilidade de casamento, o que, como veremos, tem mais peso em sua vida de mulher do que na dele de homem.

O desvendamento dessa contradição é apresentado em diversas passagens ao longo de Amanhecer. Maria Aparecida narradora irá, então, apresentar a idealização que fez de Antônio quando o conheceu, dois anos antes do momento em que elabora a narrativa. Como há uma intervenção significativa da narradora ao longo do enredo para antecipar as dificuldades que este encontro impôs ao seu momento presente, a contradição fica exposta a partir dessas intervenções a respeito do que narra, como a seguir:

Não haveria duas horas que eu conhecera Antônio, e já me sentia ligada a ele. Desde esse momento Ihe pertenci, num encantamento, como hoje, desencantada, Ihe pertenço. Como o Antônio daquela noite inesquecível, o Antônio que me pareceu a vitória da vida sobre a morte, o Antônio cheio de mistério e de promessas, é diferente do que agora espero todos os dias, inquieta e humilde... Naquela noite, 
ao contrário, a impressão que me comunicou foi de segurança. De confiança na vida. De confiança em mim. A aprovação que sentia nele - aprovação que se estendia do meu corpo às minhas palavras - me revelava a mim mesma. (PEREIRA, 2006, p. 294)

Sem essas frequentes intervenções da narradora no presente, que alertam para o que o seu próprio desencanto, seria-nos só possível observar o que the foi desfavorável no final do romance, entretanto, com isso, fica nítido durante todo o enredo que, apesar da importante presença de Antônio no seu processo de conscientização sobre sua condição, ele também exercerá um papel opressor. Mas não será só através da voz da narradora que isso se ilustrará, porque também Sônia se ressente com este papel. Antônio também terá participação no processo de transformação que ocorre em Sônia, o qual permite certa inversão de posicionamento entre ela e Maria Aparecida. São as ideias de Antônio, sendo assim, que possibilitam a inversão de papéis entre Maria Aparecida e Sônia.

Nesse sentido, Antônio parece ocupar um papel intermediário entre Gabriel (de Para além do amor) e Flávio (de Maria Luísa). Isso porque, muito embora não apresente uma faceta tão negativa quanto este último, tampouco representará o intermediário que precipita certa emancipação, como aquele. Antônio é o homem que faz um papel intermediário entre a Maria Aparecida personagem dos fatos narrados e o mundo, incutindo nela questionamentos que the serão decisivos para, por exemplo, sua renúncia ao casamento. Mas, na contramão de Marta, Aparecida não será capaz de se desvencilhar de Antônio como intermediário, ainda que no final aponte para o fato de que já não mais o idealiza. Este personagem representa, dessa forma, assim como procuramos apontar em Artur, um homem moderno que vai escamoteando certa ideologia patriarcal no que tange o poder sobre a vida da mulher, mas que, no entanto, numa sociedade em que a autonomia da mulher é tão limitada, exercerá sobre ela o estímulo a se emancipar, naquilo, claro, que não the atinja os privilégios.

A mudança de percepção sobre Antônio sofrerá significativa transformação a partir do momento do reencontro entre os dois no Rio de Janeiro. Maria Aparecida, depois de deixar a casa dos pais de Sônia com o apoio de Antônio, será despejada da pensão em que se hospeda, porque "a dona da pensão não gostava das visitas de Antônio" (p. 363), o que deixa entrever que a sua relação não era bem vista 
sequer na sociedade urbana carioca, que em muito se diferenciaria da de São José, segundo as percepções da protagonista antes de sua mudança. Obrigada a alugar um apartamento, passa então a depender financeiramente dele, uma vez que seu salário não era suficiente para financiar o aluguel. Essa sequência de eventos evidencia novas condicionantes que se irão impor à narradora, que saiu de São José acreditando em uma emancipação: a econômica (uma vez que precisa de sua ajuda para custear sua vida no Rio de Janeiro) e a social (uma vez que está agora submetida aos julgamentos morais da sociedade).

O comportamento de Antônio com relação à Maria Aparecida, quando esta já se encontra na cidade, corresponde, em detrimento ao seu discurso sobre a necessidade de emancipação total da mulher, a uma ideologia patriarcal que, se não é igual, é muito próxima a de Juca, conforme já tinha lhe alertado a mãe. Por isso, muito embora a narradora tenha ciência de suas próprias escolhas, e, assim, rompa, ela mesma, com a imposição de dada ordem, num movimento contestador, Antônio se apresentará de acordo com a mesma ideologia opressora que rege o poder do homem sobre a mulher no casamento.

Aparecida se torna, dessa maneira, uma espécie de assistente de Antônio para que este fortaleça seus próprios ideais mantendo o conservadorismo social a que critica, ainda que embasado em pressupostos que parece contestar. Uma coadjuvante que passa a exercer, então, a função correspondente à esposa, de atendimento ao marido, mesmo que a ela tenha sido negado o casamento, em subserviência aos ideais dele. Essa lógica intrínseca à relação vivida por Maria Aparecida corresponde à possibilidade restrita de trabalho da mulher dos anos 1930. Ocupando alguns específicos postos profissionais, às mulheres cabiam os papéis de assistentes ou coadjuvantes, conforme nos alerta Margareth Rago:

Em qualquer caso, o campo de atuação da mulher fora do lar circunscreveu-se ao de ajudante, assistente, ou seja, a uma função de subordinação a um chefe masculino em atividades que a colocaram desde sempre à margem de qualquer processo decisório. (RAGO, 1985, P. 65)

Dessa maneira, em Maria Aparecida incide, como revela sua própria perspectiva, dois aspectos fundamentais que operam no sentido de não lhe 
possibilitar qualquer emancipação. Torna-se coadjuvante na trajetória idealista de Antônio e se torna uma força de trabalho aos moldes que Rago (1985, p.65) também revela como sendo o caminho possível às mulheres de baixa renda: a datilógrafa (que configura o mesmo estatuto das atividades das domésticas, operárias, costureiras, telefonistas).

Ao revelar o que era e o que se tornou Antônio, explicitando que dele não consegue se desvencilhar, à luz dessa sequência de eventos narrados, não nos parece que a narradora alude simplesmente a sua decisão a uma vontade individual, senão, também, a essa conjuntura social a qual está submetida a partir de uma relação que não se faz pelo casamento. Há nessas primeiras décadas do século XX uma insistência em manter a mulher fora do ambiente público, do trabalho, e voltada para o casamento e os cuidados para com a família e, muito embora o discurso de Antônio se coadune ao da prática anarquista do momento, que já versava sobre a liberdade da mulher, o amor livre e o divórcio, isso em nada correspondia às imposições sociais moralistas do período que vinculavam a mulher solteira que trabalhava à prostituta. Neste sentido, Maria Aparecida acaba presa a Antônio pelas condicionantes sociais, e Antônio, embora no discurso apresente uma faceta liberal nos costumes, mantém-se a ela ligado através de um jogo de poder intuído a partir de tal condicionante social.

Sendo assim, se a Maria Aparecida não prende as amarras do casamento de Maria Luísa, está ela presa pelas correntes da mesma ideologia que determinava as condições de vida da mulher de 1930, com o mesmo conjunto de regras morais, através das quais são as mulheres educadas e controladas para servir a um homem, em detrimento do tipo de relação que se estabeleça entre eles:

Antônio ficou sendo, para mim, o tipo de rapaz estróina. Estróina e de bom coração. A própria encarnação da boêmia. Estudante pobre, inteligente, altivo, bom filho, mas capaz de loucuras por amor - eu não duvidava de que ele tivesse amado aquela loura implicante cobri-o de todas as qualidades capazes de inflamar o coração da menina romântica que eu era. Não foi por ele que me apaixonei, foi por esse falso Antônio. $E$ ainda hoje não consegui destruir inteiramente em mim essa imagem que não tem nada de verdadeira. O Antônio que eu espero todas as tardes - que quase nunca vem - 
é ainda, apesar de tudo, um reflexo daquele que me deslumbrou em São José. Por mais que ele faça, não consegue me fazer aceitar a realidade, como diz. (PEREIRA, 2006, p. 296)

Essa percepção ficará ainda mais esclarecida quando a narradora estabelece a diferença de liberdade que há entre os dois a partir da dinâmica social estabelecida que também prepondera em sua relação:

Todas as suas teorias se resumem, na prática, num ciúme de marido patriarcal. Conheço bem o olhar de desconfiança com que me recebe, quando, por acaso, eu me atraso um pouco. Não é capaz de confessá-lo, mas sofre quando me vê conversar muito com algum dos seus amigos.

Agora só ele é livre... mas de que serve queixar-me? Fui eu quem o quis, que me ofereci como escrava, que me anulei. (PEREIRA, 2006, p. 365)

Temos então que as atitudes de Maria Aparecida estão mensuradas pela passividade não só por ela mesma, como também por Antônio, o que deixa entrever que este se respalda nesse aspecto para manter a narradora ligada a si, fato que embora ela mesma não evidencie em seu discurso, o desenrolar narrativo desvela. Antônio lhe impõe e lhe enxerga submersa em uma passividade, que busca controlar ao chamá-la, por exemplo, de "sempre excessiva" (p. 365), o que têm correspondência com o que Rago (2017, p. 579) coloca acerca dos militantes da década de 1930 que viam as mulheres como "passivas e inconsistentes". Ainda que a teórica aqui se valha da análise da forma como as mulheres trabalhadoras eram avaliadas nessa sociedade, os valores impressos no discurso de Antônio que o aproximam do ideal anarquista nos permite essa alusão.

Ainda assim, no final da narrativa, a narradora expõe objetivamente o que até então vinha anunciando em seus comentários do presente a partir do que contava no passado. Mesmo se entendendo presa à relação, o que atribuímos também às condições sociais que orbitam na sociedade em que vive, Maria Aparecida desvenda a questão da superioridade em Antônio, revelando que agora só ele próprio se acha superior a ela, e não mais o contrário: 
Acreditará realmente que é um homem superior, predestinado? Eu já acreditei nisso; hoje não acredito mais - para mim ele é apenas um homem, o meu homem. Fui-lhe descobrindo muitas fraquezas, que ainda me fizeram querer-lhe mais bem. Outro dia, estivemos cerca de cinco horas trabalhando juntos, ele ditando e eu escrevendo à máquina; quando acabamos, como eu me queixasse de cansaço, ele disse, sem rir:

- A história registrará o seu nome como minha colaboradora.

$\mathrm{Na}$ hora só reparei que ele me considerava sua colaboradora, e isso me fez muito feliz. Mas não sei que demônio impiedoso obrigou-me a analisar tudo, e me fez achar meio ridícula a frase. (PEREIRA, 2006, p. 366-367)

E se, dessa maneira, não consegue ainda se livrar do que a une a ele, tampouco mantém a idealização de outrora que ainda mais a submetia, numa visão bastante lúcida, causada por um demônio da consciência, acerca de sua condição de mulher numa sociedade de ideologia patriarcal.

\section{Uma renúncia ao casamento}

Em Amanhecer, a imagem do casamento vai se configurando aos poucos através da narrativa de Maria Aparecida, e tem suma importância na estrutura do romance, uma vez que apresentará, em alusão ou contraponto, as perspectivas ideológicas que se vão modificando na narradora, assim como em Maria Luísa e Para além do amor. A primeira passagem que remete a ideia de casamento está inscrita no início da narrativa, logo no primeiro capítulo, quando a narradora conta a história da Casa Verde. Esta imagem, no entanto, aponta para o viés opressivo uma vez que define a casa em que a morta da Casa Verde vivia seu casamento como uma gaiola a lhe funcionar como prisão (p. 273).

Há, ao longo da narrativa, na dinâmica das imagens que vão sendo construídas, uma ambivalência entre a independência que almeja (cujo primeiro 
ensejo aparece antes mesmo de Antônio surgir como personagem) e a ideia de casamento em Aparecida, que de certa maneira remete à característica do binômio antigo e novo presente nos romances anteriores, e que não serão conciliáveis no desenvolvimento narrativo. Este aspecto é apresentado no início do romance pela narradora: "Eu fui ficando em São José. A princípio muito contrariada, depois conformada porque, no íntimo, esperava outra solução melhor - o casamento" ( $p$. 277).

A esta ambivalência, a narradora responderá, na maior parte das vezes, com um viés pessimista, o que parece apontar que nem a ideia de independência nem a de casamento são totalmente convincentes para o seu projeto de emancipação. No entanto, é interessante notar que em algumas passagens a independência se constituirá como fator positivo, remetendo a uma felicidade momentânea ou a uma esperança com relação ao futuro que pretendia construir em sua vida. Ao contrário disso, ainda que o casamento se configure nos planos de Aparecida em muitas passagens, a imagem que é construída sobre ele é negativa, vias de regras, baseada na observação da narradora sobre a experiência de outras mulheres na narrativa. Duas delas de significativa importância na constituição narrativa, conforme já apontamos anteriormente nesta análise: a morta da Casa Verde, cuja imagem (da prisão em gaiola dourada) respaldada ao destino trágico (o suicídio) apontam para a infelicidade; e a mãe, cujo casamento também apresenta a perspectiva negativa acionada pela infelicidade. A primeira passagem em que temos o diagnóstico da infelicidade da mãe ocorre também no início do romance, ocasionada pelo diálogo entre Aparecida e o padre, quando esta, aconselhada pela tia a se tornar freira, sente repulsa a essa ideia e, culpada, vai ao confessionário:

- Mas reflita bem, minha filha, sua tia é muito mais feliz do que sua mãe.

Isso era verdade. Coitada e mamãe, eu nunca tinha imaginado que ela fosse tão infeliz como diziam. Nunca até então a ouvira queixarse. E tinha bem de que... (PEREIRA, 2006, p. 278)

Assim sendo, temos consolidada nesses dois exemplos a imagem da infelicidade do casamento na vida dessas mulheres. Outras, ainda, irão respaldar tal construção. Em conversa com Luísa, podemos entrever a experiência que a mãe 
desta tem relacionada ao casamento: "Mamãe diz que casamento só serve pra gente trabalhar mais" (p. 281). No entanto, essa ideia não se estabelece sem contradições, uma vez que as personagens não casadas apontam para certa expectativa otimista. É o caso da própria Luísa, nesta mesma passagem, ou em outra, poucas páginas depois, como no diálogo entre Sônia e Maria Aparecida, em que esta pensa que aquela estava alçando uma purificação através de uma nova perspectiva, que, no entanto, a equipara à morta da Casa Verde, cujo destino, como sabemos, é trágico:

- Às vezes tenho inveja de você... Quem sabe se o ideal não é mesmo sonhar com um noivo, esperar por ele, só se dar a ele? Eu... Ela não me deixou acabar.

- Eu? Já ouve tanta coisa na minha vida, tanta coisa que eu queria esquecer...

De repetente deu uma gargalhada e exclamou:

- São José está me fazendo terrivelmente burguesa. Se o pessoal soubesse havia de rir de mim.

Não importa, fiquei com pena dela, com tanta pena... Tinha a impressão de que ela se purificava. Por vezes, chegava a confundila com a morta da casa verde. (PEREIRA, 2006, p. 288-289)

A partir da experiência que vive com Antônio, que será, como também já sabemos, uma espécie de propulsor intelectual que ajuda a viabilizar a transformação que ocorrerá em Aparecida, esta, que já ambicionava a independência e que, no entanto, conformou-se com a desautorização dos pais sobre sua ideia de trabalhar, irá ser motivada a repensar o seu projeto que incluía o casamento:

Em vez de falar de mim, de nós, do nosso caso, falou em geral das relações entre os homens e as mulheres. A virgindade - como me envergonhou essa palavra! - o casamento eram preconceitos. Preconceito burguês a noção de honra feminina. O prazer é desfrutado tanto pela moça como pelo rapaz; não há culpa para aquela nem responsabilidade para este. Deviam ser dois parceiros, 
não emprestando gravidade as coisas que não a tinha. $\mathrm{O}$ amor era muito raro e o instinto, muito premente.

$(\ldots)$

Pediu-me desculpas; de ora em diante veria em mim uma irmã; devia ter percebido logo que eu não era como as outras, as pequenas que conhecera até então, mas uma sobrevivente de outras épocas, desgarrada no mundo moderno. Não estava preparada para ver a vida real. (PEREIRA, 2006, p. 299)

Maria Aparecida parece sofrer a partir de então o seu processo de transformação de uma "sobrevivente de outras épocas" para uma mulher que viverá no "mundo moderno", o que fará com que ascenda em si a vontade de independência e liberdade, que, entretanto, não ocorrerá sem contradição. Assim, durante esse processo, que podemos observar não completamente finalizado até o fim da narrativa, a ambivalência independência e casamento continua atuando na sua reflexão sobre sua condição de mulher. Temos então que em um momento se vê caminhando para o abismo devido à experiência com Antônio (p. 303) e, simultaneamente, constata que não queria como destino a vida de solteirona de " $D$. Célia do Correio, ir murchando, murchando, envelhecer sem ter conhecido a vida. Nunca que eu me sujeitaria a isso!" (p. 309).

O processo que a encaminha para a escolha da independência (ainda que sob dependência de Antônio) em detrimento do casamento tem seu estopim a partir da descoberta da traição do pai à mãe, porque é justamente depois disso que abre mão de sua virgindade ${ }^{23}$, tão cara à mulher dos anos 1930: "Eu não fiz nada. Estava atordoada, vazia. Nesse dia é que papai morreu de verdade, para mim. E no dia seguinte, quando Antônio veio, não relutei em ir com ele para o fundo da chácara" (p. 306).

Maria Aparecida já estava ciente, então, de que Antônio não casaria com ela (p. 312), mas admite, a partir da observação sobre o comportamento do pai, que o casamento talvez fosse uma possibilidade mesmo hipócrita, mais do que isso, uma possibilidade em que prevalecem os privilégios dos homens sobre as mulheres.

\footnotetext{
${ }^{23}$ Apesar das significativas mudanças precipitadas nos anos 1920, Os anos loucos, ainda em 1930, como durante muito tempo depois, a virgindade era uma exigência social para as mulheres até o casamento. Ao se referir ao início da década de 1920, diz-nos Del Priore (2015, p. 255): "A repressão sexual era profunda entre as mulheres e estava relacionada à moral tradicional".
} 
Obviamente, esse processo culmina numa necessidade de escolha, que a narradora irá expor que sofreu:

Não era nenhuma novidade que Antônio não quisesse casar comigo. Até já estava resignada a isso. $E$ entretanto sofria doidamente, tinha a impressão de estar num pesadelo. As palavras de D. Célia, os olhares dulçurosos de Seu Josino, Luísa se escondendo de mim, Antônio marcando-me na sua vida num lugar ao lado, tudo isso me dançava dentro da cabeça, de misturada, como se uma ligação misteriosa unisse esses fatos diferentes. (...) E enquanto corria, com a chuva a me escorrer pelos cabelos, a me ensopar o vestido, vi que o meu tormento (...) Vinha de mim mesma. Era a angústia da escolha, de quem está entre dois caminhos. (PEREIRA, 2006, p. 317)

A angústia da escolha entre dois caminhos resulta na sua primeira recusa efetiva ao casamento, proposto então por seu Josino. Sem ter qualquer afeto ou admiração por este, e ainda que soubesse de antemão a sua negativa à proposta, Maria Aparecida não responde imediatamente ao pedido, porque esta resposta está incorporada em sua narrativa justamente por esse processo de transformação pelo qual estava passando. E embora o intuito da mãe fosse afastar Antônio quando lhe conta sobre o tratamento que Ihe dispensava o pai, acaba, na verdade, confirmando a sua negativa ao casamento:

Baixava a cabeça, aturava tudo; ainda tinha que lhe ser grata porque o casamento me livrou da desonra. Depois que nos casamos, vivemos como dois estranhos. Eu era moça e não era feia; pois ele nunca mais viu em mim uma mulher, a mulher dele. (PEREIRA, 2006, P. 332)

Este entrecho, usado por duas vezes nesta análise, revela duas coisas simultaneamente na construção narrativa, a ideologia patriarcal exposta na relação do pai com a mãe, conforme já apontamos, e, por outro lado, a infeliz experiência da mãe no casamento. Sendo assim, afirma-se na voz narrativa os dois lados desta mesma moeda, o do homem e o da mulher, que ratificam definitivamente o processo 
de transformação em Aparecida, mesmo que, por vezes, a ideia da vida de casada ainda se faça presente, o que ela irá recusar de agora em diante: "Mas logo afastava essa ideia. Seria renunciar à luta, dar parte de fraca. Queria era ser independente, construir a minha vida com meu trabalho" (p. 340).

A recusa não se consolida apenas no plano das ideias. Em seus primeiros momentos no Rio, Maria Aparecida conhece Carlos, a quem inventou uma personagem em que, não sendo exatamente ela, projetava a ideia que Antônio vinha lhe construindo de mulher independente. Carlos pede Maria Aparecida em casamento, e esta recusa - "respondi-lhe que mulheres como eu não se casavam" (p. 355). Assim, há aqui objetivamente o segundo não ao casamento. Para além do que projeta em suas reflexões, portanto, há uma recusa que se repete ao casamento, consolidando, neste momento, um posicionamento que já havia admitido anteriormente. Longe disso indicar uma ruptura na ambivalência, no entanto, a narradora ainda irá intercalar os momentos de exaltação da própria independência com momentos em que reflete sobre o casamento, como podemos observar nos seguintes entrechos:

E eu me sentia tão contente, tão feliz. Estava instalada no Rio, ganhando minha vida. Olhei para as árvores, para o mar, para a avenida com olhos novos, como se tudo o que via fosse um pouco meu, como se, de repente, eu tivesse adquirido mais direito aos prazeres, à vida. Não era mais "a filha do Juca Lobato", a menina educada por favor, perdida em São José, de quem se achara digno o Seu Josino conferente. Era uma mulher, alguém que existia por si, que tinha raízes na vida. (PEREIRA, 2006, p. 353)

Ás vezes, cruzando tanta gente desconhecida pelas ruas, penso que talvez esteja ali, entre aqueles anônimos, alguém que me poderia dar o que Antônio me recusa: um nome, um lar, uma situação estável.

Mas é só um momento de tentação... sei muito bem que alguma coisa de superior à minha vontade me prende a Antônio. (PEREIRA, 2006, p. 367) 
Esse processo, no entanto, é sempre respaldado pela imagem negativa que a narradora, em primeira pessoa, vinha construindo ao longo de sua narrativa, o que fica afirmado, por exemplo, quando esta sabe do novo casamento da mãe:

(...) quando recebi a carta de mamãe, dizendo que ia se casar com Seu Josino, pouca importância dei ao caso (...). Mas pensei que só agora ela ia viver uma vida que Ihe convinha, aquela vida tranquila, mas apagada e humilde que me horrorizava. Cada um com seu destino. (PEREIRA, 2006, p. 366)

Se em Maria Luísa e Para além do amor temos como eixo central no desenvolvimento de consciência de condição e reestruturação ideológica das narradoras a relação das protagonistas com o adultério (que opera bastante no sentido de quebrar uma lógica opressiva do modelo esposa-mãe imposto às mulheres), em Amanhecer isso parece ocorrer na decisão entre o casamento ou a independência. No entanto, em Maria Aparecida a aversão ao casamento, o que configuraria uma espécie de ruptura à opressão a que mulheres casadas estavam expostas, não se efetiva, uma vez que há esse jogo ambivalente configurado no seu narrar através das suas dúvidas e queixas, ainda que seu processo de transformação resulte numa escolha por não se casar. Confabulada desta forma, a escolha parece estar muito mais vinculada à renúncia ao casamento do que se negar de fato a ele. Embora recaia muito sobre Antônio, e em grande medida ele seja realmente o sujeito que interfere em sua escolha, ele também parece assumir aqui o papel metafórico da independência que ela escolheu, em algum sentido. Evidencia-se isso através das diversas passagens em que, enxergando já o homem que tem ao lado como "apenas um homem, o meu homem", a narradora ainda assim se sente presa a ele. A renúncia ao casamento, desta forma, configura-se não só como o desejo de estar ao lado de Antônio como, também, e talvez principalmente, pelo desejo de independência da narradora exposto desde o início narrativa que vai se compondo e se fortalecendo no jogo ambivalente.

No entanto, tal renúncia, que parecia projetar a independência, não admite um processo emancipatório completo, uma vez que se trata aqui de uma sociedade de mentalidade patriarcal, o que implica em um limite bastante eficaz em qualquer desenvolvimento social ambicionado pela mulher, que, ainda que (ou principalmente 
se) atinja alguma independência, será marginalizada. O que, aliás, a narradora intui muito antes do encaminhamento do desfecho da narrativa:

Foi então que eu comecei pôr a liberdade acima de tudo. Parecia-me que a liberdade era o maior bem, e a queria por qualquer preço. Fiz sacrifícios para conquistá-la. E hoje a liberdade me pesa tanto que há momentos em que me sinto capaz de todas as baixezas para sentir-me depender de alguém superior a mim. A minha prisão a Antônio é diferente, porque é voluntária, é criada mais por mim do que por ele. (PEREIRA, 2006, p. 339)

\section{Um desfecho pessimista (ou melancólico)}

A renúncia torna-se assim a palavra-chave em nossa análise nesse processo de ambivalência que irá resultar no desfecho deste romance de Lúcia Miguel Pereira aqui estudado. Entretanto, a passagem final do romance parece conjecturar para uma história em aberto. Assim como Maria Luísa, Maria Aparecida está sob a égide de condicionantes da vida da mulher que evoca nela um fim de trajetória frustrado, mas, ao fim da narrativa, reage a essa frustração, ainda que não tão propositada pela ação como Marta, de Para além do amor.

Maria Aparecida reconhece o isolamento que a relação com Antônio lhe encerrou e é justamente a tentativa de sair desse isolamento que lhe faz escrever a sua história, portanto, o leitmotiv dessa narradora é ocasionado pela condição social que lhe é imposta agora, no presente, a partir de uma escolha que the coloca à margem socialmente, porque renuncia ao que era validado como obrigação da mulher do período. Entretanto, partindo dessa marginalização, tem o direito de voz ao contar a sua própria história sob o seu ponto de vista:

Foi com medo dessa morte rápida, foi para fixar Antônio dentro de mim, que comecei a escrever a minha vida nestes últimos anos. Mas escrevi também como quem chora, como quem grita. Ainda não tenho 20 anos completos e o meu destino já se cumpriu. Neste Rio com que tanto sonhei, vivo anônima. Não conheço ninguém. 
$\mathrm{Na}$ Companhia sou apenas uma funcionária, uma máquina de trabalho. Só vejo, raramente, os amigos de Antônio, que são poucos. Não vou mais a Copacabana; D. Sinhazinha soube de minha ligação com Antônio, e fechou-me a porta. (PEREIRA, 2006, p. 367)

E no ato de narrar expõe as suas contradições e as do momento presente no processo de modernização da mulher brasileira do período, do qual falaremos adiante. A sua escolha pela relação com Antônio e por sua independência é questionada durante toda a narrativa com a perspectiva da problemática do presente. Assim, pontua a frustração com relação a Antônio ao mesmo tempo em que anuncia sua necessidade de independência, que no processo de ambivalência são encadeadas sempre como resultante uma da outra:

Apesar de tudo, eu ainda esperava que alguma coisa se passaria, pensava que um destino me fora traçado, muito cheio de acontecimentos. Traçado por Deus que, a despeito das minhas fraquezas, de Antônio, velava por mim e me levaria ao caminho, nem que fosse por linhas tortas. Não sabia que a vida é uma longa, longa espera, sem nada no fim. Hoje sei... (PEREIRA, 2006, p. 311)

Antônio fez-me muito mal, tem-me feito sofrer muito; matou a minha alma, matou o meu coração, matou em mim tanta coisa... mas isso eu Ihe devo; foi ele quem me fez compreender que a minha dignidade estava em ser independente, em só contar com o meu trabalho. A única dignidade que me resta. (PEREIRA, 2006, p. 308)

No entanto, assim como em Maria Luísa, o desfecho é consolidado por uma espécie de retorno ao ponto anterior à transformação, mas uma volta modificada. Se em Maria Luísa isso significou a retomada de seu papel de esposa e mãe, agora sem a autoridade que lhe confiara forjar o modelo, em Maria Aparecida isso acontece com o questionamento ao amor que sente por Antônio, agora não mais idealizado porque ela sofreu um processo de conscientização, que aponta para um Antônio que exerce controle. 
Dessa forma, o final nos remete ao pessimismo, uma vez que a narradora observa o aspecto ruim de sua relação com Antônio (a marginalização) com mais ênfase do que o bom (a independência), já que de alguma forma estão ambos atrelados em sua condição de mulher, restringido aquele a dinamização deste. No entanto, como é possível observar no entrecho acima, a própria narradora vincula a independência que tem a Antônio, que a impulsionou, projetando sobre essa perspectiva um viés melancólico, uma vez que suscita ao longo da narrativa certo abatimento resultante de sua frustração com o isolamento em que vive. O final, portanto, aqui, também encaminha a narrativa para uma espécie de resignação já presente em Maria Luísa, mas não se fixa, pois que é feito em uma pergunta que abre para outras possibilidades reflexivas. Diante da constatação de que espectro patriarcal que é presente no casamento também é observável em sua relação com Antônio, de maneira bastante problemática, como Sônia elucida: "Antônio quer tudo você, mas sem dar nada" (p. 368), a narradora conclui: "Será esse, só esse, o meu destino, minha Nossa Senhora da Aparecida?" (p. 369).

\section{A Ilha Verde, de Maria Lamas}

A Ilha Verde, de Maria Lamas, foi publicado em 1938, como sendo o segundo romance em que a escritora assina com seu próprio nome, depois de Para além do amor. O enredo traça a história de llonka Torney, uma húngara que, em passeio por ilhas portuguesas, conhece o português Duarte de Medeiros, um rapaz de 27 anos, que a convence a conhecer a "sua" Ilha de S. Miguel, também conhecida como Ilha Verde, nos Açores, onde irão viver uma história de amor. llonka difere-se em costumes das mulheres açorianas apresentadas no romance e sobre ela recaem todos os tipos de preconceitos dos habitantes da Ilha. Defensora do amor mais livre, llonka receberá, por quase todas as outras personagens do romance, incluindo Duarte, a alcunha de aventureira.

Neste romance de Maria Lamas o casamento continua figurando como tema, muito embora aqui ele não seja central, cedendo espaço para o questionamento, que já perpassava Para além do amor, do amor romântico, mas tangencia as formas de relação que se estabelecem entre as personagens, à exceção de llonka. Nesse 
sentido, difere-se um pouco dos romances anteriormente estudados nesta tese, uma vez que casamento é a chave de análise para o desenvolvimento de todas as outras protagonistas e narradoras estudadas até aqui, incluindo Marta, de Para além do amor.

Em A Ilha Verde, o cenário deixa de ser uma cidade-capital, como era Lisboa no primeiro livro estudado da romancista, e se transfere para uma cidade menor. $\mathrm{O}$ mesmo deslocamento que ocorre de Maria Luísa, que se passa no Rio de Janeiro, para Amanhecer, parcialmente em São José, é notável aqui já que a llha de São Miguel terá presença significativa na narrativa uma vez que a narradora se deterá na descrição das paisagens e dos costumes detalhadamente, numa perspectiva aproximada ao olhar da protagonista-estrangeira que ali vê em quase tudo novidade. A paisagem será, dessa forma, parte fundamental da narrativa. 0 arquipélago de Açores é formado por ilhas vulcânicas, de vulcões em não atividade, e este aspecto é basilar na narrativa para tecer, também, a personalidade da protagonista, como buscaremos apontar. Além de ser estrangeira, e húngara - o que corrobora em si um aspecto exótico mesmo para os padrões dos europeus ocidentais -, mais dois aspectos se alocarão na personagem llonka: trata-se de uma mulher de elite econômica e uma artista. Em relação ao primeiro aspecto, não se contrasta em relação às outras personagens principais e secundárias do enredo, no entanto ela se contrastará significativamente com os moradores pobres da ilha. Já no segundo aspecto, diferencia-se não só desses, como também das primeiras, cuja mentalidade "provinciana" a protagonista critica por diversas vezes ao longo da narrativa. llonka é, portanto, uma artista estrangeira rica que, diferente de todas as outras protagonistas que analisamos até agora, não será influenciada, por contrário, será influência no comportamento de outras personagens. O que ocorre nesta inversão é que aqui, tanto quanto em Maria Luísa na sua primeira parte, a protagonista aparenta ter superioridade quando comparada às outras pessoas a sua volta.

No entanto, o romance de Maria Lamas também é engendrado por outras personagens mulheres, que configurarão o espelhamento dos comportamentos de llonka, em uma versão que se apresentará mais ou menos conservadora na representação das mulheres portuguesas: Isabel, Maria Luíza e D. Brites. No entanto, o papel central deste espelhamento será desempenhado por Maria Luíza, a namorada de infância de Duarte, que com ele espera se casar. 


\section{Lugar social da protagonistas e esboços da narradora}

llonka é uma mulher estrangeira que está de passagem por Portugal. Compreendemos então que o lugar social apresentado no romance tem esta marca de algo que é transitório, não fixo e, desta maneira, diferente de uma realidade local portuguesa. Temos contato com esta dimensão na abertura do romance:

Mais uma ilha! Esses fragmentos de mundo, com seu quê de rebeldia a desafiar a vastidão das águas, atraíam-na irresistivelmente, para the darem depois a sensação aflitiva de ser ela própria uma prisioneira do mar.

Sentia, então, o desejo de fugir. E partia, como quem se liberta, para começar logo a ter saudades... (LAMAS, 1938, p. 7).

Além de ser definitivamente alguém "de fora" daquele espaço, como é frisado ao longo do início da narrativa em que Duarte apresenta à llonka alguns locais da Ilha, ela também será apresentada como sendo uma mulher burguesa, assim como as outras personagens que se apresentam no romance. No entanto, no que tange a questão de gênero, llonka não comporá com as outras o mesmo lugar social vinculado a certa ideologia patriarcal, uma vez que defende o tempo todo a sua liberdade. Tendo em vista este aspecto, é a narradora mesmo que virá nos esclarecer seu caráter paradoxal, que a torna diferente, para além do fato de ser estrangeira, de outras personagens dispostas no romance: "Eram assim as suas resoluções: súbitas, impulsivas. De sinceridade primitiva, llonka Torney, mulher civilizada, era, paradoxalmente, um animal bravio, refractário a qualquer disciplina" (p. 8).

No contraponto entre o civilizado e o primitivo configuram-se as relações que llonka estabelecerá com a ilha e seus habitantes, no que estes sempre receberão, na perspectiva dela, o caráter de provincianos. Além disso, tal contraponto permitirá, por outra via, que se estabeleça uma relação entre llonka e o espaço narrativo, uma vez que a natureza vai metaforizando aquilo que a narradora lhe classifica como instinto, o que será significativo na narrativa e a diferenciará, 
irremediavelmente, das outras personagens, mesmo de Duarte, que por um tempo viveu fora de São Miguel.

Estrangeira, em momento de trânsito, rica e artista são os principais componentes que farão com que llonka figure como o antônimo do provinciano que observará na paisagem humana da ilha. A isso, a narradora, por vezes, estipula sua perspectiva sobre a protagonista:

\begin{abstract}
llonka sentia-se alvo de todos os olhares, como se tivesse a atracção de escândalo na pacatez de burgo provinciano. E dera-se a exagerar, por capricho, a sua maneira de ser, naturalmente desdenhosa e altiva, sempre que pressentia censura ou discordância com as suas atitudes. (LAMAS, 1938, p. 10-11)
\end{abstract}

No entanto, saberemos também que llonka não será só a partir do olhar provinciano da llha uma mulher diferente, também ela o é em seu próprio meio, conforme a narradora evidencia:

(...) sempre insatisfeita, sempre diferente de si própria, foi de cidade em cidade, de ilha em ilha, de Palace em Palace, sem outra finalidade que não fosse viver, dando-se ela própria à vida, plenamente, e gozando-a com todo o vigor dos seus sentidos e de sua inteligência.

Encontrou dedicações fortes, constantes. Porém, soube conservar sempre a maior independência, considerando-a indispensável à sua tranquilidade. E os amigos aceitaram-na assim mesmo, desigual, complicada, mas encantadora e sempre leal. (LAMAS, 1938, p. 6465)

A protagonista do romance é, portanto, uma mulher cuja vida não está circunscrita às regras da sociedade em que vive. É alguém que se posiciona ao reverso do que lhe é imposto socialmente, muito embora não viva à margem, devido ao seu poder econômico. Este ponto permitirá que Ilonka se sobressaia inclusive às relações de poder que se estabelecem entre outras personagens homens e mulheres na narrativa, mas a narradora, diante disso, também elabora sua perspectiva crítica sobre a llonka, que admite certo posicionamento de 
superioridade com relação às outras e aos outros, como pudemos observar na disposição dos entrechos acima, principalmente através dos adjetivos desdenho e altivez. O que nos permite dizer que também a relação entre a narradora e llonka se dará de forma paradoxal, por vezes através de uma perspectiva aproximada que a remete para o lugar de uma mulher como as outras, por vezes com uma perspectiva distanciada que procura desvendar em llonka uma falsa superioridade, uma vez que a perspectiva aproximada apresenta as suas semelhanças às demais.

A perspectiva aproximada da narradora e da protagonista ocorre, principalmente, no início da narrativa, a partir da percepção da natureza local elucubrada a partir da observação de llonka sobre aquele espaço desconhecido em que adentra. Durante os três primeiros capítulos do romance há uma persistência na descrição narrativa que aponta para essa perspectiva, uma vez que ao mesmo tempo em que a narradora apresenta a paisagem local sob o olhar de llonka, associa essa paisagem ao seu comportamento:

A ilha e o mar desenhavam recortes caprichosos, sublinhados por uma orla branca de espuma. E a costa, abrupta e majestosa, tinha assim uma expressão de ansiedade, uma assimetria que sugeria inquietação e incerteza.

Ilonka perdera completamente o ar enigmático de mulher presa a um sonho de aventura. Tinha o riso moço, o olhar deslumbrado de dezoito anos sem malícia. O primitivo e o hiper-civilizado eram-lhe familiares. Então? Qualquer inexplicável afinidade entre o seu eu e a paisagem... Talvez a misteriosa atração que, subitamente, a prendesse à Ilha Verde... (LAMAS, 1938, p. 37; 38-39)

Assim, a essa visão que sobrepõe inquietação e incerteza aos aspectos naturais locais vai se adensando a personalidade da própria personagem, também ela, segundo a narradora, caprichosa e inquieta. Essa organização que transversa a protagonista e a paisagem pode ser contemplada durante toda a narrativa e será também responsável por oferecer o contraste entre llonka e Maria Luíza, assim como adiantar os caminhos do seu desenlace com Duarte. Há uma semelhança significativa entre Marta, a narradora de Para além do amor, e a narradora de A Ilha 
Verde nesse sentido. Assim como lá, Marta reflete sobre si mesma através de longas descrições narrativas que elabora sobre a paisagem, aqui a narradora irá traçar o mesmo percurso para melhor definir llonka.

O contraste é assim evidenciado por duas vazões sensíveis no texto. Se a protagonista é a estrangeira que, com relação ao povoado da ilha, apresenta consideráveis diferenças comportamentais, sendo ela a representação de civilização em contraponto ao provincianismo conservador, tal qual nos evidencia a proximidade da narradora através do discurso indireto livre, a natureza irá adornar, por sua vez, o seu lado instintivo, já estipulado como paradoxo anteriormente. llonka, ao não se identificar com a sociedade local, identifica-se com a natureza, e, para melhor a entendermos, a narradora realiza o procedimento de metaforizar a ela a natureza, que será apresentada em suas características vulcânicas, em passagens como: "Porém, uma vibração indefinível, vinda de insondáveis profundezas, passava como frêmito de vida, na própria neblina. Sentia-se a realidade duma beleza forte, sob a incerteza aflitiva das nuvens rastejantes" (p. 33); ou ainda: "Lá muito do fundo, das entranhas da terra, vinha um rumor abafado, tal como gemido de monstro em agonia. Nalguns pontos, o solo escaldava. $\mathrm{O}$ ambiente era verdadeiramente infernal" (p. 53).

Tal característica expressará os tipos de emoções que estão impressas na personagem e que respaldarão seu discurso, em alguns momentos contraditórios, acerca do amor. Não acreditando no amor romântico, llonka também não acredita na permanência deste sentimento na vida de dois amantes e desinteressa-lhe, segundo o que ela mesmo expõe em diversos diálogos com Duarte, a manutenção de um amor do qual se tornaria prisioneira. Embora em mais de uma passagem do romance a narradora deixe entrever, sem explicações mais detalhadas, que esse pensamento está vinculado às decepções amorosas que a personagem viveu, é evidente que o que é posto em destaque é sua atual disposição sobre o tema. Sendo assim, a caracterização da llha, vulcânica, parece ocorrer em llonka que defende relações em que a preocupação central não seja a constância, portanto, que prescinde o casamento.

O casamento não será um tema muito debatido por llonka uma vez que prevalece sua perspectiva do amor que é contrária a essa instituição. Diferente dos outros romances até aqui estudados, as reflexões da protagonista que são acompanhadas pela narradora não pairam sobre este tema. llonka colocará, em 
suas próprias argumentações, em xeque o amor romântico, num procedimento que parece uma radicalização das últimas decisões de Marta em Para além do amor, que ao final do romance renuncia à vida com Gabriel em prol de um projeto de construção com outras mulheres. Aqui, llonka se recusa ao que considera ser a prisão do amor, em última instância, o casamento, em prol, objetivamente, de sua liberdade.

Justamente nesse ponto essa personagem se distingue sobremaneira das demais personagens mulheres do romance, assim como, aparentemente, da narradora, uma vez que esta, apesar de não apresentar ironia com relação à llonka, apresenta uma perspectiva de maior proximidade com as mulheres portuguesas aqui representadas, o que podemos observar pela escolha da narradora em aludir, diversas vezes, às reflexões da protagonista um sentimento de superioridade ou altivez, enquanto não desenvolve qualquer perspectiva de crítica negativa no tratamento de Maria Luíza. Podemos observar uma relativa perspectiva crítica da narradora com llonka na passagem abaixo, por exemplo, quando apresenta uma visão da protagonista que contrapõe seu próprio ponto de vista, uma vez que observa com negativo nos outros hóspedes um comportamento que reflete o seu próprio, em não aceitar outra regra da vida que não seja a sua:

llonka riu mais do que o costume, exagerando a sua animação, e comentou, com ironia, a vulgaridade da maioria dos hóspedes, notando-lhes certo ar desconfiado de quem não vê com bons olhos outra regra de vida que não seja a sua. (...) Armando concordava, não fosse ela considera-lo, também, um "provinciano"... (LAMAS, 1938, p. 63)

Por outro lado, também, a narradora evidencia que este contraste entre os locais e a estrangeira apresenta-se reciprocamente, o que amaina o teor da crítica da narradora sobre ela: "O aspecto de llonka, na sua indumentária e na sua maquilhagem ultra-moderna, assustava homens e mulheres, como se ela trouxesse consigo qualquer coisa do inferno" (p. 103), principalmente porque essa identificação de llonka com o inferno na perspectiva dos locais será contraposta por uma narradora com ponto de vista aproximado ao seu. 
Dessa forma, a narradora assinala para o contraste, vezes aportando-se de um lado, vezes de outro, principalmente através das outras mulheres personagens do romance. Sobressai-se nisso a necessidade de liberdade de llonka, que elabora nela uma manifestação do desejo que não é compartilhada, sequer aceita, pelas outras. Por isso, llonka será estruturada como o avesso das outras e, principalmente, de Maria Luíza, com quem, ao final da narrativa, Duarte insinua que se casará. Portanto, também durante a primeira parte narrativa é perceptível que tanto o desejo quanto a necessidade de liberdade de llonka reverberem não só em seus diálogos como também em suas reflexões, por vezes contraditórias, que se sobressaem na estrutura narrativa através do discurso indireto livre. Podemos observar exemplo disso nos entrechos abaixo:

Não, decididamente, o amor não contava na sua vida! Era apenas um prazer físico, ou mesmo intelectual, necessário ao equilíbrio dos seus nervos de animal saudável. Sonho? llusão? Ternura? Talvez, para quem pudesse acreditar ou estivesse disposto a renunciar ao bem sem preço, de ser livre! E nenhum homem valia semelhante sacrifício. O amor romântico era uma deformação sentimental que a sua sinceridade instintiva repudiava.

E queria viver intensamente o seu amor! Duarte dava-Ihe uma felicidade nova, toda vibrante de sensualidade e alegria. Era um amor sem complicações de sentimentos desencontrados, simples, instintivo e dominador. (LAMAS, 1938, p. 65; 97)

Observa-se que, diferentemente do que se opera na voz narrativa da primeira parte de Maria Luísa, também realizada em terceira pessoa, aqui não há indícios de ironia com relação à protagonista ou ainda aos outros habitantes da llha. Pelo contrário, a narradora parece observar a tudo evitando emitir sua opinião, ainda que, como discutiremos adiante, a organização da autora implícita indicará as preferências da narradora. llonka vai assim sendo tecida pela voz narrativa através dos contrastes com os outros e consigo mesma, uma vez que a narradora deixa entrever aspectos de seu passado que não combinam com sua postura presente mas que para isso contribuíram, como a timidez adolescente em contraposição à 
altivez que assume na llha, ou ainda sua opção por não viver um amor duradouro em contraposição à decepção amorosa que aqui é só aludida. Seu percurso se configura dessa forma durante parte do desenrolar narrativo, modificado quando começam a agir sobre a relação de llonka e Duarte as impressões e exigências de determinada ordem social, a que ele irá respeitar e, por fim, por isso mesmo, afastála. Isso será perceptível principalmente através da atuação da família Medeiros, cujo julgamento sobre llonka se altera quando se evidencia sua relação afetiva com Duarte.

É a partir deste ponto que, muito embora o casamento não configure preocupação central para llonka, se tornará o motivo da ação de toda a família Medeiros para ocasionar a ruptura da relação dos dois, uma vez que ela não é considerada o modelo de esposa e mãe que esperam para Duarte, o que causará impressões na protagonista:

Que the importavam esses projectos matrimoniais? A vida não lhe interessava sob esse aspecto. O que maçava enormemente era sentir uma hostilidade mal disfarçada e descobrir com frequência curiosidade maldosa nos olhares que encontravam o seu. (LAMAS, 1938, p. 149)

Assim, o que antes vinha tecendo uma espécie de contradição relativa, ou paradoxo, entre o comportamento de llonka na relação que experimenta e suas reflexões sobre a liberdade, converge, progressivamente, para a conclusão desta de que deve, quanto antes, afastar-se da ilha que vai se configurando como sua prisão, "ela não pudera nunca permanecer muito tempo numa ilha, sem ter a sensação de estar prisioneira (p. 143)", ao mesmo tempo que reconhece em si sua antiga personalidade anterior a Duarte:

Ao mesmo tempo reencontrou a sua verdadeira personalidade aquela llonka rebelde, amante do amor instintivo, para quem o resto do mundo era somente comparsaria que a sua altivez desdenhava.

(...)

Mas aquele anseio de amorosa escravidão, que subtilmente se lhe vinha infiltrando na alma, estava vencido. llonka era, de novo, a mulher que ama sem se deixar prender. (LAMAS, 1938, p. 153-4) 
llonka identifica então em Duarte a mesquinhez dos homens comuns, que aqui está associada à necessidade de corresponder à demanda familiar e social para com o casamento e, principalmente, a manutenção de uma ideologia patriarcal que enxerga como sua possível prisão:

Duarte começava a amesquinhar-se a seus olhos; e ela perdoar-lheia mais facilmente um defeito grave que fosse uma afirmação de força do que pequenas mentiras e indecisões vulgares.

Duarte agradava-Ihe, mas parecia-Ihe, agora, estar mais perto da vulgaridade dos homens. E, quando, a seus olhos, se confundisse inteiramente com qualquer outro, deixaria de a interessar. (LAMAS, 1938, p. 148;154)

O desencantamento provoca em llonka um encontro com as suas características iniciais, como nos previne a narradora: "Mas o desencantamento já começara... Subtilmente, a antiga llonka, insatisfeita e indomável, triunfava da outra que o amor tinha enfeitiçado" (p. 172). E ele se estende não só para Duarte, como também para a ilha, uma vez que o seu ponto de vista sobre a paisagem desloca-se da ideia de beleza para a de estranheza, medo e tristeza, progressivamente, ao mesmo tempo em que suas concepções sobre o amor romântico do início da narrativa vão se edificando novamente: "Agora era a revolta o que sentia e raciocinava conforme as suas teorias anti-românticas: - O amor só é belo sem escravidão nem ciúmes mesquinhos!" (p. 181).

A narrativa então se encaminha para o final e para a ruptura inevitável entre llonka e Duarte, mais do que isso, para a ruptura entre llonka e aquilo que na Ilha iria Ihe aprisionar, evidenciando uma coerência entre as percepções iniciais da personagem e sua decisão final, que foram entremeadas por dúvidas respondidas conforme as imposições sociais foram se conformando no comportamento de Duarte:

llonka não fez um movimento. Por fim, deixando de se dominar, sofreu como qualquer mulher que não se envergonha de chorar por um desgosto de amor. Vencida aquela prova, estava senhora de si, 
mas sentia morrer uma parcela de sua vida. Qualquer coisa, na sua alma, se destruíra irremediavelmente. O amor... Como era bom gostar de alguém, e como ela gostara de Duarte! Tanto, que chegara a acreditar na eterna ilusão: - para sempre! Como se fosse possível! O amor é deslumbramento e êxtase. Só um desejo, só um querer, só uma vibração!

Duarte poderia, talvez, tê-la prendido, mas hesitara, e essa hesitação, gerada no seu subconsciente por influências que a ele próprio passaram desapercebidas, sentira-a ele, desde o primeiro instante. (LAMAS, 1938, p. 207-208)

Finalmente, conclui sua liberdade não só com relação a Duarte, como também em relação à estrutura social arquitetada ali:

Duarte dominava ainda os seus sentidos e a sua alma, mas a inteligência libertara-se e com ela a inquietação. Já o amor não era Amor!

Pensassem dela o que quisessem! $O$ importante era partir como tinha chegado, de sorriso nos lábios e a altivez indiferente de quem não dá pela existência do que the não interessa. E em S. Miguel, só Duarte e a ilha a tinham interessado. Tornara-se, pois, indispensável ser acompanhada por Duarte até o fim. Exigia-o o orgulho e a elegância espiritual de que não abdicava. (LAMAS, 1938, p. 207; 210)

A partir deste panorama, faz-se necessário que nos detenhamos sobre as relações com as outras personagens que irão delinear na narrativa as ideologias presentes na voz que narra.

\section{Orquestração do feminino das personagens: Maria Luíza, Isabel e D. Brites}

Assim como em todos os outros romances até aqui analisados, em $A$ llha Verde também o espectro de um determinado papel da mulher será elaborado a 
partir de personagens mulheres do romance. A central, como sabemos, será llonka, além disso, outras colaboram nessa elaboração, como Maria Luíza, a namorada da época de adolescência de Duarte, Isabel, a irmã de Duarte; e D. Brites, sua mãe.

Maria Luíza é configurada como aquilo que é oposto em llonka. Nascida e criada na llha, sobre ela operam as imposições sociais locais, das quais llonka é relativamente protegida por ser estrangeira, como apontamos. Maria Luíza espera se casar com Duarte desde que este foi a Lisboa estudar. Não há nela a mesma liberdade que há na protagonista, pelo contrário, Maria Luíza vem representando seu oposto em termos de posicionamento e papel social de gênero e isso será evidenciado pela narradora através dos contrastes entre suas personalidades que é representado também na natureza enquanto metáfora. Enquanto para llonka as paisagens da ilha invocam atração, para Maria Luíza invocam melancolia, como podemos observar nos trechos referentes a uma e a outra, respectivamente:

Demorou-se a pensar na llha de S. Miguel. Interessava-a vivamente. E, sem saber definir como, a llha Verde e Duarte confundiam-se na mesma misteriosa atracção, fazendo-a vibrar numa ansiedade forte, que dava prazer ao seu temperamento ávido de renovação e plenitude.

Sabia como a lua costumava transformar as suas águas quietas em planície de luz fantástica, onde alastrava a sombra gigantesca dos picos que se erguiam em redor, e se recortava a silhueta esguia da ermida-túmulo que fala de morte e amor. (LAMAS, 1938, p. 18; 6768)

Este contraste será ainda enfatizado pela profundidade que a paisagem admite em Maria Luíza que a encaminha para o extremo oposto do que estava transposto até agora em llonka, uma vez que as sensações desta são resultantes de uma primeira experiência, enquanto as daquela fazem parte da repetição cotidiana:

Em dias de neblina, ou quando a chuva crespava as águas ao de leve, a lagoa transformava-se em visão de tristeza. As garças fugiam assustadas; o recorte dos montes perdia-se na bruma, e as próprias almas sentiam-se esmagadas por estranha nostalgia, como se a 
realidade ficasse longe, tão longe que nem o pensamento a pudesse alcançar. (LAMAS, 1938, p. 68)

Desta forma, fica também definido o contraste destas duas personagens com relação às experiências que Ihes são atribuídas pela narradora, uma vez que em llonka é constante a busca pela novidade "inimiga declarada das repetições" ( $p$. 115) e àquilo que o novo pode trazer de prazer às suas percepções, e em Maria Luíza é presente a repetição de uma vida sistematizada e experimentada a partir de um mesmo lugar. Assim, ficarão estruturadas como opostos perante a ordem dominante na ilha, uma vez que a conformidade à mesmice em Maria Luíza invoca o modelo de esposa (dentro da mesma perspectiva esposa-mãe presente nos outros romances analisados nesta tese) enquanto a inquietação em llonka a coloca no papel de aventureira que, não fosse o espaço que a perspectiva narrativa dá às suas reflexões, poderia equivaler ao atributo negativo, análogo ao da prostituta, no contexto social aqui refletido.

É importante notar, porém, que se há entre as duas uma oposição que repercutirá nas relações que estabelecem com Duarte e que tal oposição seja transpassada pelo ciúme, tanto de um quanto de outro lado, não se constitui, efetivamente em termos de ação no romance, uma disputa entre as duas, a não ser através das perspectivas de outras personagens, como Isabel, D. Brites e Armando. Isso é significativo quando comparamos, por exemplo, com Amanhecer, no qual durante uma parte do enredo Maria Aparecida e Sônia, que são amigas, se vêm às voltas de disputar a atenção de Antônio. Embora se relacionem com a mesma figura, uma através da projeção do casamento e a outra através da experiência presente de relação, Maria Luíza e llonka não disputam diretamente a atenção de Duarte, mesmo porque aquela fica esquecida por ele na presença desta.

Maria Luíza, sendo assim, assume um posicionamento completamente passivo diante dos acontecimentos (só lhe acode a ação de pedir por um milagre durante os rituais religiosos locais), ao revés de llonka em que não paira resquício de passividade, uma vez alocada conforme já procuramos demonstrar na altivez. O que mais uma vez faz refletir em Maria Luíza o modelo da esposa ideal, conforme os padrões sociais aos quais responde, e também, é bom enfatizar, conforme os padrões impostos por um Estado cada vez mais autoritário em termos de papel social da mulher, já configurado no final dos anos 1930, sob o regime salazarista. 
Se é a volta da mulher ao lar que é requisitada neste momento, Maria Luíza em tudo seguirá esta demanda, não à toa, quando deixado por llonka, será nela que Duarte irá se centrar. Entretanto, esta personagem é travestida de passividade e melancolia que, ainda que conte em determinados momentos com uma voz complacente da narradora, apresenta uma mulher subjugada a um homem e, por isso, infeliz. E isso é notável não só porque tudo o que no enredo narrativo perpassa por ela é configurado por essa passividade e melancolia como pelo fato de sua voz desaparecer no desfecho do romance, ficando apenas sugerido o casamento com Duarte através da voz deste. No entrecho abaixo, evidencia-se que é justamente esta passividade e resignação da espera que irão despertar em Duarte, ainda que envolvido com llonka, algum interesse:

Reagiu quanto pode, para não deixar transparecer a sua perturbação, mas todos notaram, embora não o dissessem, que os seus olhos brilhavam intensamente, como se neles houvesse lágrimas, e as suas faces tinham um rubor febril.

Duarte achou-a, mesmo, mais bonita. (LAMAS, 1938, p. 126-127)

Assim, ao contrário de llonka, Maria Luíza constitui neste romance o estereótipo ideal da mulher para o casamento perante uma ideologia patriarcal, na mais estreita relação de submissão que assume ante o seu amor de infância, portanto, o mesmo amor idealizado que llonka critica. E na submissão a esse amor aproxima-se de Maria Aparecida, mas não há nela os mesmos questionamentos da protagonista de Amanhecer, que é submetida, pelos desenvolvimentos reflexivos que efetua narrando a sua própria história, a um processo de conscientização de seu lugar social. Pelo contrário, como a narradora poucas vezes se aproxima de Maria Luíza a não ser para iluminar o seu sofrimento consequente do desprezo de Duarte, há pouca reflexão em Maria Luíza, o que delineia mais uma distância entre ela e llonka, uma vez que nesta o caráter reflexido é preponderante. Entretanto, há entre esses opostos assim confabulados uma terceira personagem que esboça uma espécie de entremeio: Isabel.

Isabel, irmã de Duarte, é amiga de Maria Luíza desde a infância, no entanto, as diferenças entre as duas são evidenciadas pela narradora tão logo elas se tornam presentes no desenvolvimento do enredo: 
Eram inseparáveis, embora com feitios opostos: Isabel, muito viva, faladora, gênio arrebatado, fazia triunfar sempre os seus gostos e opiniões, fosse na vida familiar, fosse em festas e reuniões de sociedade; Maria Luíza, serena e pouco expansiva, dava a impressão de viver num mundo aparte, presa a um vago sonho, e, na roda dos seus conhecimentos, era tida por acanhada. (LAMAS, 1938, p. 70)

Isabel será a outra possibilidade social da mulher dentro dos limites sociais impostos às mulheres de São Miguel. Quando comparada à Maria Luíza, toma uma vertente progressista, através não só da sua personalidade mais expansiva, como também das suas ações efetivamente menos passivas. Será ela que irá, por exemplo, questionar o comportamento do irmão para a mãe, quando esse toma proporções de escândalo na ilha, assim como será ela que irá interceder a favor de Maria Luíza, com quem se preocupa, não só pela amizade que lhe tem como também por enxergar nela a mulher que tomaria pra si as suas obrigações familiares com os pais que envelhecem. Para tanto, irá apontar sua desconfiança com relação aos homens na figura do irmão:

Só Isabel é que não se deixou convencer assim, tão facilmente. Fosse a valer, ou fosse um passatempo, aquela intimidade com a húngara não lhe agradava. Achava a outra interessante demais para ser inofensiva. E pensava sempre em Maria Luíza. Uns ingratos e uns estúpidos os homens. $O$ irmão, com as suas prosápias de superioridade, não fugia à regra. Mas, com ela, não levaria a melhor. Havia de falar-lhe e abrir-lhe os olhos, para que visse o que devia ser.

Isabel remoía em silêncio as suas preocupações, disposta a agir na primeira oportunidade. O seu namoro com Mario de Lemos encaminhava-se para o casamento e ela não queria deixar a ilha sem ter a certeza de que Maria Luíza tomaria o seu lugar junto dos pais, já velhos e sempre adoentados. (LAMAS, 1938, p. 196; 198) 
Torna-se assim um intermediário do feminino entre Maria Luíza e llonka, uma vez que quando contrastada com esta, apesar do posicionamento menos passivo, apresenta também a sua versão mais conservadora, ao revés da "aventureira", como considera a outra, ainda que não tão submissa, Isabel também constitui um estereótipo da esposa:

Por seu lado, Isabel, indignada com a atitude do irmão, chegou a pensar em procurar llonka, para Ihe dizer, nem sabia o quê, mas, em todo o caso, para lhe fazer sentir que a sua permanência na ilha estava tomando proporções de escândalo. Por que não deixava Duarte em paz? Não the haviam de faltar admiradores e apaixonados, por esse mundo a fora!

No entanto, não ousara por em prática este projecto, receosa de merecer a desaprovação dos pais e pelo natural pudor de abordar um assunto escabroso para a sua situação de "filha de família". (LAMAS, 1938, p. 192)

Isabel apesar do seu posicionamento questionador sobre a ordem dada, obedece à ordem, encaixando-se nos padrões. E se questiona o comportamento masculino, não se opõe a ele efetivamente. Isso determina em Isabel uma diferença do conservadorismo a que responde a sua mãe, o que a coloca como certa modernização da mulher na dinâmica social da ilha; na contraposição de Maria Luíza, de um lado, e llonka de outro, parece ser nela que a dialética entre o antigo e o novo papel social da mulher naquela sociedade irá atuar.

D. Brites aproxima-se aqui de D. Constança bem como de D. Laura. Tem uma atitude obediente e subordinada ao marido, que considera que deve regular a ordem familiar, mas seus julgamentos serão apontados pela voz narrativa, como fazia a narradora de Maria Luísa. "Perfeita dona de casa, tornara-se notável nas doçarias, condão especial e muito tido em conta pelas mais distintas senhoras açorianas. Alheava-se sempre das questões materiais que considerava de exclusividade competência do marido" (p. 117). Representa, então, a mulher em sua função social de esposa e mãe, exclusivamente, a quem cabia os afazeres doméstico e a educação dos filhos, mas a quem não cabia, porém, uma posição de autoridade ao lado do marido nas diretrizes familiares. Será então, quando comparada à llonka, a 
baliza avessa: o que há de provinciano, dentro da dinâmica narrativa, no comportamento feminino; quando comparada à Maria Luíza, uma espécie de modelo, porque na sua retração Maria Luíza também assume o caráter submisso; e um contraponto de Isabel, que, apesar de se submeter à ordem social imposta, também é capaz de questionar esta ordem. D. Brites terá papel decisivo, no entanto, na representação do que chamamos em Maria Luíza de antigo paradigma. E é através dela que são feitas as críticas mais contundentes aos comportamentos de llonka:

No íntimo, D. Brites absolvia o filho. Há mulheres com artes do inferno, capazes de enfeitiçar um santo. Quantos casos ela ouvira contar! O perigo era Duarte deixar-se prender... Tinham de libertá-lo daquela tentação. A noiva talhada para ele era Maria Luísa. E, se não fosse Maria Luíza, não Ihe faltariam, na ilha, raparigas de sua igualha, por onde escolher.

Simpático, desempenado, era um belo rapaz! Um homem! Fora gerado no seu ventre, amamentado com o seu leite, e agora... Qualquer aventureira, de olhar tentador, seria capaz de lho roubar. A eterna ingratidão dos filhos...

D. Brites disse logo que sempre tivera a certeza de que o seu filho não seria capaz de deslustrar o nome que usava e considerou llonka "uma qualquer" que não se toma a sério. Duarte tinha razão: exageravam. (LAMAS, 1938, p. 119; 125; 195-196)

Em A llha Verde, assim como em Maria Luísa, Para além do amor e Amanhecer fica orquestrado um determinado lugar do feminino através de diversas personagens que se complementam e contrapõe, apresentando uma espécie de mosaico que evidencia o papel social da mulher na sociedade portuguesa de 1930, aqui elaborado de maneira contrastante com a outra, que será, por sua vez, representada por uma estrangeira fora dos padrões impostos à sociedade portuguesa da época. A configuração dessa outra, que tem protagonismo, torna-se, assim como nos outros romances, efetivada pela maneira contrastada a diversas personagens com as quais coexiste. Para tanto, também aqui a presença das 
personagens masculinas irá fortalecer certa perspectiva ideológica patriarcal, que reverberará no desenrolar narrativo, e na forma como llonka é prospectada.

\section{A figuração do patriarcal nas personagens masculinas em $A$ Ilha Verde}

A figuração do espectro patriarcal, assim como nos outros romances até aqui analisados, ocorre principalmente através de dois fatores: o comportamento das mulheres submetidas a essa ordem e a voz masculina que se consolida nas personagens homens. Sobre este último fator deteremos esta parte da análise.

São quatro os personagens que farão essa representação, sendo um deles o mais importante: Duarte de Medeiros, com quem llonka e, no seu reverso, Maria Luíza irão se relacionar. Com Duarte teremos acesso àquilo que é delineado pela exigência à ordem que circunscreve a possibilidade de ação de llonka. Ainda que ciente desde o início do posicionamento da protagonista que infere aprisionamento a uma relação de amor em que paire a permanência, ou seja, o casamento, Duarte irá tentar impor esta ordenação do comportamento social em llonka, a partir de questionamento ou ações, como podemos observar ao longo de todo o enredo narrativo. Tal configuração é elaborada já nos primeiros diálogos que ocorrem entre os dois, como podemos acompanhar nas páginas inaugurais da narrativa, quando as personagens se apresentam uma a outra e elaboram suas respectivas visões sobre o amor:

- E o que pensa do amor?

- Aí tem um mito criado pelos poetas.

- Conforme o sentido que der a essa palavra.

- O sentido mais belo, o único que ela pode ter: a união perfeita de duas vidas que se completam...

- Pra sempre... - conclui llonka, sublinhando as palavras com um riso prolongado. - Não, não acredito no amor, pelo menos no amor literário que desafia a própria eternidade!

- Na boca de uma mulher nova, bonita, inteligente, essas palavras são uma blasfêmia! 
- E agradeço-lhe, sabe? É tão agradável encontrar um amigo inteligente e leal. Porque nós vamos ser dois grandes amigos! Queres?

- Encanta-me essa ideia!

- Apesar de eu ser assim tão "revolucionária"?

- Talvez por causa disso mesmo. (LAMAS, 1938, p. 13;18)

Observemos que por ser nova, bonita e inteligente, llonka, sob o ponto de vista de Duarte, não poderia ser crítica à noção de amor prolongado, ao mesmo tempo em que admite que a sua perspectiva revolucionária é que o possa atrair. O que fica ainda mais evidente no acentuado apontamento que a narradora infere: "Ele sentiu mais forte a curiosidade, a atração da mulher que se adivinha diferente do comum, na inteligência, na alma, no amor" (p. 32). Se a princípio, embora desperte a desconfiança, esse apontamento de Duarte não aparenta relevância, no desenrolar narrativo ele desponta como um primeiro indício de que ele não vê outra possibilidade para Ilonka que não ceder, então, ao que esta, desde o princípio, recusava-se.

Ainda se evidencia que Duarte entende como capricho a reflexão de llonka, por isso mesmo passível de modificação:

Sorria a sua boca, sorriam os seus olhos claros; toda ela era, a bem dizer, um sorriso de mocidade e alegria ingênua. Duarte olhava-a surpreendido e via-a outra, totalmente outra, sem traço físico ou moral daquela que, numa tarde cinzenta, em pleno Atlântico, se lhe confessara caprichosa e descrente no amor. (LAMAS, 1938, p. 43)

Torna-se notável então que Duarte deseja estabelecer uma relação de domínio sobre llonka e, para isso, é necessário desconstruir nela a noção que tem sobre o amor, em sua perspectiva de mulher nova, bonita, inteligente e crítica à ordem social que the imputa como resultado do amor a prisão em um casamento. No entanto, isso será revestido de desconfiança por llonka que se vê diante de uma "cilada", mesmo ali na primeira parte da narrativa, quando para a protagonista Duarte ainda não assumiu o seu lugar de "homem vulgar": "- Não falo das caldeiras. 
Refiro-me à cilada que o seu amigo me anunciou... Creio ter compreendido; tudo é tão belo, tão estranho..." (p. 54).

A resistência que llonka estabelece ao amor irá, invariavelmente, magoar ou atrair Duarte, que busca vencê-la, desqualificando a capacidade de autonomia reflexiva da personagem, já evidenciada pela narradora, como rebeldia ou capricho: "Aquela rebeldia sentimental de llonka magoava Duarte. Chegava mesmo a irritá-lo, tornando mais forte o seu desejo de a prender. E queria-lhe, talvez por isso mesmo, com mais ardor". É importante notar, entretanto, que será a narradora que fará contraposição a Duarte neste sentido, uma vez que ela detém a onisciência dos fatos e contrasta as juras que ele faz à llonka com as que, antes, havia feito a Maria Luíza, a quem agora não dá qualquer importância. Ainda que resoluto em seu "sonho de a prender sempre, ao seu destino", poderemos observar o início de uma mudança que ocorre em Duarte a partir do momento em que a família Medeiros inicia suas intervenções na relação do filho com a estrangeira, a quem seus pais e sua irmã passam a tratar como aventureira. Tal mudança resultará, ainda que sutilmente, por enquanto, num novo olhar que estabelece em Maria Luíza, a quem até então não notava:

Duarte achou-a, mesmo, mais bonita. Gostou de a ver e falou-lhe com intimidade afectuosa. Veio-lhe ao pensamento, por instantes, o idílio esboçado noutro tempo, e sorriu, no seu íntimo, ao rever-se tímido adolescente, julgando ter descoberto o mundo nos olhos claros e serenos duma amiga de infância.

A imagem de llonka veio logo sobrepor-se à figurinha gentil que se se esfumaçou numa vaga saudade. (LAMAS, 1938, p. 127)

Nessa configuração do patriarcal que se configura em Duarte temos então o contraste entre a "figurinha gentil" e llonka, cuja potência estava justamente em resistir às regras as quais Duarte gostaria de submetê-la. Há, então, na narrativa, a partir do momento em que o personagem aponta o contraste entre llonka e Maria Luíza uma intervenção da narradora, que desvincula-se pontualmente do seu posicionamento retido na observação e deixa entrever sua crítica ao comportamento de Duarte: 
As facilidades materiais, uma saúde robusta e o desprendimento natural do seu feitio haviam-no tornado egoísta e vaidoso. Ao egoísmo e à vaidade devia ele a liberdade sentimental de que até há pouco fizera gala. Nunca tivera prisões; os seus entusiasmos eram rápidos; gostava hoje, para se fatigar amanhã. Achava naturalíssimo que as mulheres se apaixonassem por ele, mas considerava-as apenas bonecas vivas, nascidas para seu prazer. Se um dia pensasse em casar, então teria tempo de tomar as coisas a sério. $\mathrm{E}$ algumas vezes, ao ocorrer-Ihe esta ideia, acontecia que a imagem de Maria Luíza se desenhava na sua lembrança. Sem se demorar em querer saber a razão, acreditava que ela esperaria por ele. Entretanto, ia vivendo ao sabor do seu capricho. Era o seu direito de homem!

Fora assim até encontrar llonka. E enquanto atravessava a pé, sem pressa, a cidade pacatamente adormecida, Duarte pensava na amante, no encanto da sua convivência, no que havia nela de enigmático e desconcertante, sentindo-se capaz de the sacrificar conveniências, família, tudo! O seu temperamento impetuoso, habituado a conseguir quanto desejava, excitava-se mais ainda, ao sentir que alguma coisa, em llonka, Ihe escapava, e à ideia de ter que lutar contra a oposição dos pais. (LAMAS, 1938, p. 128-129)

É importante notarmos que a narradora imputa a Duarte duas características que vão se relacionar com o seu direito de homem: a vaidade e o egoísmo que the deram a liberdade sentimental, a mesma liberdade que ele considera capricho do comportamento impetuoso de llonka. Ainda neste entrecho, a narradora estabelece uma comparação entre o jogo de sedução que Duarte pratica tanto com Maria Luíza quanto com llonka, assumindo um posicionamento contrário ao filho Medeiros. Revela-se, aqui, portanto, uma narradora posicionada efetivamente contrária, porque crítica e irônica, a um personagem, Duarte, que é justamente quem tentará exercer o controle de outras personagens: llonka e Maria Luíza. Embora não se consolide todo o enredo narrativo nesta mesma perspectiva crítica, aqui, ao permitir que acessemos sua opinião, a narradora aponta para o que antes vinha sendo construído sem sua intromissão, deixando explícita e enfatizada a sua oposição ao comportamento de Duarte. 
Se como resposta à família, Duarte passará, ainda que lentamente, a olhar para Maria Luíza, que corresponde aqui ao que já mencionamos como modelo de esposa; e à resistência de llonka (que volta à tona exatamente porque agindo assim Duarte se transforma em "homem vulgar", como todos os outros) ele irá passar a imputar a mesma noção de aventureira que outros personagens já haviam Ihe dado: "Duarte não respondeu. Aquelas palavras fizeram-lhe mal. E se o amor de llonka fosse apenas uma ânsia de aventura sugerida pela ilha? Se ele não passasse do indispensável colaborador dessa aventura?" (p. 143), ainda que na ausência de seus familiares ele escolhesse "continuar a sua deliciosa aventura..." (p. 155).

Isso irá se desenvolver ainda mais nas páginas seguintes, quando percebe que llonka, agora, vem ratificando o posicionamento que desde o início afirmara ter, mas que aqui se transformará definitivamente em qualidade negativa que aplica a ela o papel inverso, porque independente e livre, ao de esposa a que corresponde Maria Luíza, e por isso gera em Duarte a desconfiança:

Talvez tivessem razão... Naquela mulher havia qualquer coisa de aventureira. la jurar que o aviador francês estava ligado à inesperada resolução que ela tomara. Lembrou-se de procurar Armando. Devia ter notícias para Ihe dar" p. 203).

Tem-se assim a tensão entre a esposa e a aventureira na estruturação que se elabora através da atuação e reflexão de Duarte, as duas categorias únicas em que se encaixavam as mulheres na sociedade patriarcal dos anos 1930, se livre, prostituta, se submissa, esposa, o que elucida a crítica da narradora estabelecida anteriormente. Essa transição na maneira de ver llonka não acontece sem contradição, como podemos observar na passagem:

A recordação das horas que tinham vivido juntos vinha, de repente, abrandar a sua irritação. Fora tão feliz com ela! Ilonka revelara-lhe tanta coisa bela da vida, do amor, da própria ilha que ele só agora "descobrira" verdadeiramente! Não, não era possível que tudo tivesse acabado! (LAMAS, 1938, p. 204) 
E por isso, Duarte, mesmo que llonka o avise de que partirá da llha, sente arranhar a sua vaidade de quem não venceu a resistência de uma mulher, que considerava apenas caprichosa, o que a narradora destaca: "O que ele pretendia era fazê-la mudar de resolução. Não acreditava que ela se mantivesse firme no propósito de partir. Caprichos de mulher! E, vaidoso, esperava triunfar ainda" ( $p$. 211). A figuração do patriarcal na tentativa de exercício do seu controle que foi se configurando ao longo da narrativa em Duarte tem, em seu final, o momento de destaque, porque é ali, enfim, que o personagem fará a sua opção, liquidado o relacionamento por escolha de llonka, à Maria Luíza, em quem reconhece o atributo de esposa, ao contrário da outra, a quem que passa a ver, então, como "mais uma americana ousada":

Duarte ouvia distraído. O seu orgulho de homem e o seu amor sangravam, como se uma derrota tivesse aniquilado, nele, todas as possibilidades de ser feliz. Era a primeira vez que sofria. E simultaneamente, dir-se-ia que numa nova consciência despertara nele. Poucas horas antes de llonka embarcar, jurava a si próprio que nenhuma força humana impediria que ele se lhe fosse juntar, logo a tempestade passasse. (...) Mas, no ambiente cosmopolita do navio, llonka pareceu-lhe, de repente, semelhantes às americanas ousadas, que predominavam naquela Babilônia flutuante (...). Foi como se uma revelação brutal the paralisasse o coração. Ao acenar-Ihe, anda, da pequena embarcação em que regressava ao cais, já não era para llonka o seu gesto de despedida, era para uma grande ilusão que morria. (LAMAS, 1938, P. 234-235)

Apesar da evidente disposição em Duarte do espectro patriarcal que circunspecta llonka, não é só através dele que isso ficará elucidado na narrativa. Também se comporá em seu pai, Sr. Jacinto de Medeiros, em quem se deposita todo o poder da família Medeiros, e em seu amigo, o médico Armando de Ataíde. Ambos irão traçar um perfil de llonka a partir da mesma confabulação já apresentada em Duarte, e atribuem à autonomia intelectual, emocional e material da protagonista a negativa qualidade de aventureira.

Armando de Ataíde, com quem llonka desenvolve uma amizade, será o primeiro em que a narradora apontará tal concepção: "Aquela convivência com uma 
estrangeira - assim bem patente à curiosidade do burgo - não deixava de lisonjear a sua vaidade de homem" (p. 62-63). Aqui, assim como em Duarte, a princípio llonka desperta a vaidade apenas por sua convivência. A seguir, no entanto, ele revelará o que pensa sobre ela, atraiçoando a relação que ela estabeleceu com ele, a partir também da perspectiva de que aquela mulher ali não condiz com o papel social (de esposa) infligido a uma mulher:

Dou-te razão! Ela é encantadora, embora seja uma desiquilibrada. Em Paris, mesmo em Lisboa, estava bem. Eu faria outro tanto... Mas aqui é o diabo" Tu lá sabes... E eu não tenho feitio nem ares de conselheiro. (...) Uma aventura, vá... Mas transtornar o futuro por causa dum "pássaro de arribação"... não compreendo. (LAMAS, 1938, p. 120-121)

E mais adiante, completa: "Não tomes as coisas tanto ao sério, homem! Eu bem te preveni. Mulheres não faltam" (p. 204), confabulando assim que llonka definitivamente não merece a atenção que o amigo lhe deu por não obedecer aos padrões que se espera de uma mulher. Ao seu ponto de vista corresponderá o de Jacinto de Medeiros, quando convoca o filho a uma conversa, imposta por sua esposa, pela primeira vez em sua posição de mulher que se submete às ordens do marido, uma vez que o "comando a ele pertencia e a os seus princípios impunhamIhe obediência conjugal" (p. 119). Assim, a primeira ordenação do aspecto patriarcal em Jacinto de Medeiros desponta no poder que ele tem sobre a D. Brites, que como já apontamos representa o paradigma da mulher antiga que sequer questiona os seus papéis. Depois irá se refletir na compreensão que tem sobre a relação do filho com llonka:

- Gostar de uma mulher não fica mal a um homem. Sei o que isso é; também fui rapaz... Mas, para que fazes às claras o que podias muito bem fazer sem chamar a atenção de ninguém? Porque não apareces mais vezes na cidade? Depois de uma ausência de dois anos, era natural que nos acompanhasses mais. Eu, por mim, compreendo... Mas tua mãe e tua irmã andam desgostosas, parece que Ihes morreu alguém! Não penses que gosto de meter na tua vida particular. Mas a verdade é que é preciso ter cautela... Contam- 
se coisas deste mundo e do outro, acerca dessa mulher. Sabe-se lá quem é?! Enfim, o que desejo recomendar-te é que não esqueças o respeito que deves ao nosso nome, a tua irmã e a tua mãe, já não digo a mim. Estamos entendidos? Sobretudo ouve bem este conselho: não te prendas! Ela vai-se embora qualquer dia e, pronto, fica o caso arrumado.

No íntimo, Jacinto de Medeiros pensava: - Rapazes! Quando se viu mocidade ser sensata? - E relembrava, com pontinha de saudade, certa aventura que tivera com uma bailarina espanhola que deixara fama em S. Miguel, já lá iam uns bons trinta anos. (LAMAS, 1934, p. 194)

Define, assim, novamente, que llonka não corresponde aos padrões sociais exigidos para uma esposa Medeiros e, portanto, poderia existir apenas na medida em que seu filho pudesse guardar segredo sobre a relação, julgando que o seu comportamento ainda comprometeria não só o nome do filho, como também o nome da família, a quem o patriarca resguarda com o auxílio de sua esposa submetida ao seu poder.

Apenas para fins de apontamento, é importante a sinalização da perspectiva crítica da narradora sobre a estruturação do patriarcal para além da atuação das personagens acima, uma vez que também é realizada através de detalhes no discurso narrativo que estabelecem tal estrutura. Exemplo disso é a forma como descreve um dos eventos religiosos que ocorrem na llha em que atuam os romeiros:

Tudo neles é passividade e submissão. Despotismo de chefe de família, arrancos de gênio violento, ressentimentos e malquerenças, de tudo se desprendem os romeiros naqueles dias de expiação voluntária. À frente, o guia vai marcando o rumo, e eles seguem-no como rebanho confiado. (LAMAS, 1938, p. 58)

É possível notarmos que este espectro do patriarcal também aqui, como em Maria Luísa, Para além do amor e Amanhecer, será assegurado por sua correlação com o casamento. Desta forma, as críticas feitas à llonka são sempre circunstanciadas pela recusa ao seu comportamento que nega o casamento. Tornase, assim, fundamental que delineemos este elemento na análise. 


\section{O casamento}

Em A Ilha Verde, a ideia da dissociação entre casamento e amor romântico é ornamentada de maneira distinta de Para além do amor, e mais aproximada talvez do que ocorre em Amanhecer. Sendo assim, llonka desde o início da narrativa não admite o casamento, uma vez que não admite o vínculo indissolúvel que daria ao amor o caráter de permanente. Ainda que poucas vezes mencione o casamento, a protagonista desenvolve a sua aversão a ele quando alude que a consequência da permanência do vínculo amoroso, que teria como consequência o casamento, seria a sua prisão. Portanto, subentende-se que para llonka o casamento é uma prisão, e é a isso que ela irá apresentar resistência, ainda que vivendo uma história aos moldes românticos com Duarte. Temos então que já no início da narrativa estabelece-se a equivalência, a partir do ponto de vista de llonka, entre casamento e o cerceamento da liberdade (que nomeia escravidão), o que podemos observar no seguinte diálogo que desenvolve com Duarte:

- É assim tão volúvel?

- Sou apenas verdadeira.

- É escusado preguntar-lhe se é contra o casamento...

- Sou contra todas as escravidões.

- E a família?

- Uma teoria que falha inteiramente na prática...

- Mas isso é o cúmulo da irreverência!

- Acha?

(...)

- Não tenha ilusões: sou assim, tal qual, escandalosamente sincera e irreverente, se quiser. Pareço-lhe um monstro, não?

- Parece-me uma mulher inteligentíssima. (LAMAS, 1938, p. 16)

É igualmente no início da narrativa que temos contato com as ideias da personagem com relação ao amor, na continuidade deste diálogo com Duarte, a quem estava conhecendo. Sabemos, então, que privilegia a ideia de amor como instinto e isso ficará esclarecido em suas primeiras conversas com o português: 
- Oiça, sr. romântico: a vida só é verdadeiramente bela na sua simplicidade magnífica. Fora disso tudo é complicação e artifício. Consequência: confundimos tudo, mentimos aos outros e a nós próprios e, o que é mais lamentável, destruímos todas as possibilidades de ser felizes. Queremos, por força, amarrar o Sonho, a llusão, a Ansiedade, a uma verdade palpável. E inventámos o amor, personificando noutro ser da nossa espécie o Ideal criado pela nossa imaginação e pela incurável inquietação do nosso espírito, sem nos lembrarmos de que se trata, afinal, duma criatura inconstante, imperfeita e vulgar, tal como nós mesmos. (LAMAS, 1938, p. 15-16)

Disposta assim, temos na abertura do romance a forma como esta personagem encarará as suas relações afetivas que são desvinculadas não só da estrutura do amor romântico, como também da possibilidade do casamento. Portanto, é primeiro através de llonka que temos a negativa ao casamento, o que a fará, ao longo da narrativa, embora sua inteligência e elegância sejam mensuradas inúmeras vezes, corresponder ao estereótipo de aventureira diante de outras personagens, o que poderemos, transversalmente, ler como o inverso da esposa, que é a prostituta. Mas a narradora não estipula nela essa qualidade, uma vez que mantém uma perspectiva aproximada da sua durante boa parte da narrativa, privilegiando assim as suas reflexões de uma mulher que prioriza (porque pode, é uma estrangeira e tem recursos financeiros) a sua autonomia.

Assim, em llonka a imagem do casamento se faz apenas como negativa, vinculada à prisão e à escravidão, mas não será da mesma forma tecida pelas outras personagens do romance, que são portuguesas. Assim sendo, Maria Luíza e Isabel serão as correspondentes dos modelos de esposas nesta narrativa, assim como D. Brites o será de esposa-mãe. Por isso, sabemos também através das memórias de Maria Luíza privilegiadas pela narradora que Duarte a ela prometeu o casamento, o que ela passa todo o tempo esperando, inclusive quando este finaliza o curso e não volta para cumprir a sua promessa ou ainda, mais tarde, quando se envolve "escandalosamente", para os moldes daquela sociedade, com llonka:

Nunca, Luizinha? E, quando acabar o curso, quero casar contigo. 
Ela fugiu envergonhada. Tinha então doze anos; onde isso ia... Defendera de tal forma o "seu segredo", que nem a Isabel o havia contado. (LAMAS, 1938, p. 68)

Sendo assim, em oposição à llonka como já procuramos demonstrar, Maria Luíza tudo o que espera, naquele lugar em que viveu a vida inteira, é a realização de seu casamento com Duarte. Isabel, que também coaduna o modelo esposa, fica noiva de Mario Lemos, cuja única relevância no romance é apontar para o futuro casamento da personagem. A imagem do casamento na constituição da sociedade patriarcal em que se constrói o romance também ficará demarcada pela reação social ao relacionamento de llonka e Duarte, como evidencia a narradora "A verdade é que o caso tomou proporções de escândalo. No hotel, em todo o Vale das Furnas, ninguém ficou ignorando que llonka e Duarte tinham passado uma noite juntos, na Ribeira Quente" (p. 113).

Apesar de outras figuras aparecerem na configuração do modelo esposa, para contrapor o posicionamento de llonka, o desenvolvimento narrativo, cuja protagonista recusa o casamento, aponta aqui para uma perspectiva de aversão ao que o casamento representa, diferentemente do que viemos analisando nos outros romances. Portanto, as protagonistas desses diferentes romances vão configurando posicionamentos diferentes com relação ao casamento, que compostos em análise formulam um desenvolvimento da perspectiva crítica da mulher com relação a isso. Dessa forma, se em Maria Luísa temos constituída a resignação ao casamento e em Para além do amor temos um enfrentamento, em Amanhecer teremos uma renúncia a ele, e, finalmente, em $A$ llha Verde uma aversão. Isso também será engendrado pelos diferentes posicionamentos das narradoras e autoras implícitas presentes nas narrativas, o que ainda buscaremos analisar.

\section{Desfecho}

Inicia-se o desfecho da narrativa com mais um passeio de llonka e Duarte pela ilha, trata-se da visita à Lagoa de Sete Cidades, a mesma que, devido ao tempo nublado, não pôde ser observada por llonka no início da narrativa, quando chegou 
com Duarte à llha. Tomada pela beleza do local, depois de uma viagem que fazia "sem a exaltação dos dias em que a sua felicidade se reflectia na paisagem" ( $p$. 218), llonka observa tudo com o seu olhar "apenas" de turista, até chegar na Lagoa. Lá, a protagonista se comove diante da paisagem, o que a faz rememorar os sentimentos por Duarte no início do romance:

Da montanha que foi ciclópica fornalha e arremessou lava candente, em furioso desafio ao céu e ao mar, restam apenas os flancos torturados. No seu regaço imenso a água substituiu o fogo, ocultando o mistério das profundezas nunca devassadas. O que foi tragédia genesíaca é agora suavidade e beleza. Um milagre portentoso recobriu de luxuriante verdura as ravinas que o fogo outro calcinou. E a lagoa, na sua mística serenidade, fortemente tocada pela tristeza, comunica às almas uma saudade indefinível, como se evocasse uma vida irreal.

llonka setiu-se pequena naquela magnificência sem arrogância. (LAMAS, 1938, p. 218).

Neste arrebatamento diante da paisagem, llonka terá que resistir para não reviver com Duarte aquilo que definiu como o amor que não é Amor, porque agora já em sua fase final. Feito isso, os antigos amantes voltam para Ponta Delgada, de onde a protagonista irá partir. A paisagem da ilha tem, assim, papel fundamental na despedida de llonka e Duarte, remetendo para a melancolia, agora, do que antes era expectativa e euforia. É interessante notarmos também que a última paisagem do romance seja justamente a lagoa das Setes Cidades que encerra uma lenda de amor impossível entre a princesa e o pastor, constante na tradição oral de São Miguel. A paisagem que sugere esta lenda, mais uma vez, contribui para elucidar o final do romance em que o amor já não é possível entre a estrangeira e o português, porque requisitado por este como casamento.

llonka parte no dia seguinte na embarcação para Londres, e ao observá-la no navio, Duarte que até então se declarava disposto a ir atrás dela tão logo baixasse "a tempestade", a enxerga apenas como "semelhante às outras americanas ousadas" na "Babilônia Flutuante". Assim, o fim do amor, que Ilonka já reconhecia diante de todas as demandas sociais que pairavam sobre a história dos dois, 
finalmente será reconhecido por Duarte, que enxerga nela "apenas" mais uma mulher ousada estrangeira. A fim de demonstrar a sua descoberta, a narradora acompanhará, mais uma vez à exceção, o pensamento de Duarte, apontando para a sua perspectiva, que agora determina uma diferença fundamental entre a resignação de Maria Luíza, que the parecerá favorável ao seu novo estado após se descobrir como homem tradicional da ilha, e a insubmissão de llonka:

O nome de Maria Luíza, pronunciado pela irmã, veio, porém, acordar-Ihe na alma uma suave recordação. Pensou que ela era boa, linda e fiel ao seu sonho de criança. Depois de tantos dias de agitação e tormento, no embate constante com a vontade caprichosa e indomável de Ilonka, a lembrança de Maria Luíza foi como um bálsamo. Instintivamente, comparou as duas: uma, a paixão, a labareda, que consome; outra, o amor calmo, a luz bendita que ilumina. Ilonka partira tentada por novas aventuras, indiferente ao mal que Ihe causava; Maria Luíza, sem uma censura, esperava por ele desde menina... (LAMAS, 1938, p. 236)

A partir desta constatação de Duarte, a narradora aponta para o final do romance, que aqui já não sabemos se subscreve uma perspectiva narrativa dele ou uma versão da narradora, mas que, de qualquer maneira, tendo em vista os apontamentos que faz em Duarte ao longo da narrativa, de sua vaidade predisposta por sua função social de homem, que a si permite tudo, desde que exerça o domínio, parece-nos remeter para um sonho de amor vinculado à resignação da mulher, o sonho de amor, portanto, de um homem: "Sobre os escombros de um amor violento, um novo sonho de amor surgia docemente..." (p. 238). 
CAPÍTULO III - 0 aporte teórico 


\section{O Problema da Ideologia}

O estudo da ideologia é, entre outras coisas, um exame das formas pelas quais as pessoas podem chegar a investir em sua própria infelicidade. A condição de ser oprimido tem algumas pequenas compensações, e é por isso que às vezes estamos dispostos a tolerá-la. O opressor mais eficiente é aquele que persuade seus subalternos a amar, desejar e identificar-se com o seu poder; e qualquer prática de emancipação política envolve portanto a mais difícil de todas as formas de libertação, o libertar-nos de nós mesmos. (...) Se é racional acomodar-se a uma mistura ambígua de sofrimento e prazer marginal, quando as alternativas políticas mostram-se perigosas e obscuras, é também racional rebelar-se quando o sofrimento ultrapassa em muito as gratificações, e quando tal ação parece encerrar mais ganhos do que perdas. (EAGLETON, 1997, p. 12)

Leandro Konder finaliza a introdução de seu livro $A$ questão da ideologia da seguinte maneira: "Em vez da alternativa "ou decifras o enigma ou te devoro", a questão da ideologia, moderna Esfinge, nos provoca, irônica: "Decifra-me, enquanto te devoro" (KONDER, 2001, P. 12), expondo o problema que é trabalhar com essa questão atualmente. Esse problema fica ainda mais complexo quando não enfrentado sob as bases de uma formação em filosofia que, vias de regras, costuma perpassar o arcabouço teórico que facilita essa leitura. No entanto, arriscamo-nos na tentativa de traçar o perfil das vozes narrativas aqui estudadas enquanto mulheres, porque a dimensão ideológica definirá os contornos da proposição da narradora.

Nessa tentativa de analisar a narradora, fez-se fundamental apelar para o estudo da ideologia, que é determinante para essa configuração e que dialoga, na estrutura narrativa, com a dimensão histórica que nos romances está impressa. Para tanto, fizemos uma abordagem à medida que interessaria para tal fim, não ambicionando qualquer levantamento mais minucioso sobre o conceito, que é tão 
amplamente discutido a ponto de ser considerado um dos mais polissêmicos ${ }^{24}$. Interessa-nos, sobremaneira, o papel da ideologia perante a existência de conflitos sociais, neste caso, voltados mais à questão de gênero ${ }^{25}$.

Embora o conceito de ideologia anteceda a Ideologia Alemã, de Marx e Engels, é depois da insurgência do marxismo que ocorre uma guinada no seu decurso, que passa a ser entendido, então, de maneira sintética, como uma totalidade das formas de consciência social, que terá em seu sistema tanto o conjunto de ideias que legitima a classe dominante, a que se chama de ideologia burguesa, como o que se opõe a ela, expondo interesses das classes dominadas, ideologia proletária ou contraideologia ${ }^{26}$.

Assim, um conjunto de ideias configura a existência de um campo ideológico dominante, que corresponde e alimenta a práxis hegemônica porque atende às classes dominantes, sob o qual acondiciona-se o outro campo ideológico, que fará oposição ao dominante, mas que também atuará dialeticamente com este. Intencionamos, desta maneira, analisar essas narradoras sob a égide dupla de uma ideologia dominante e outra que a ela faz oposição. Trataremos, neste caso especificamente, da ideologia patriarcal enquanto configuração de práxis hegemônica, assegurada por uma disseminação de ideias veiculadas e fortalecidas ao longo da história através de diversos pilares (jurídicos, políticos, sociais), que implica diretamente na condição de vida da mulher, configurada aqui como o Outro, tal qual a proposta analítica de Simone de Beauvoir.

Em sendo o Outro, a mulher terá seu campo de atuação limitado pela proposição daquilo que não é o Mesmo, o homem e, desta forma, será submetida às instâncias de dominação, o que interfere sobremaneira no comportamento feminino, ainda quando a ele se sobrepõe algum nível de consciência. Assim, na tomada de consciência de gênero, que resulta e se consolida na organização de grupos de mulheres que irão lutar por seus direitos, incide certa ideologia feminista

\footnotetext{
24 "Existem poucos conceitos na história social moderna que sejam tão enigmáticos e polissêmicos como esse de ideologia" (LOWY in KONDER, 2002, p. 9).

${ }^{25}$ Por ser a questão de gênero que apresenta maior incidência ideológica nas narradoras, e não a questão de classe, embora essa apareça marginalmente nos romances, com destaque para Amanhecer e Para além do amor, nesse caso.

${ }^{26}$ (...) Marx e Engels levantaram a possibilidade de uma resposta não só teórica, mas prática, ativa, de uma contraideologia articulada a partir da ação consciente da classe operária e empenhadamente pensada por uma vanguarda intelectual revolucionária (BOSI, 2010, p. 120).
} 
que não rompe, necessariamente, com a ideologia patriarcal (dominante), mas irá nela causar fissuras, pelo movimento dialético que pressupõe:

\begin{abstract}
Além dos poderes concretos que possuem, revestem-se de um prestígio cuja tradição a educação da criança mantém: o presente envolve o passado, e no passado toda a história foi feita pelos homens. No momento em que as mulheres começam a tomar parte na elaboração do mundo, esse mundo é ainda um mundo que pertence aos homens. Eles bem o sabem, elas mal duvidam. Recusar ser o Outro, recusar a cumplicidade com o homem seria para elas renunciar a todas as vantagens que a aliança com a casta superior pode thes conferir. O homem suserano protegerá materialmente a mulher vassala e se encarregará de lhe justificar a existência: com o risco econômico, ela esquiva o risco metafísico de uma liberdade que deve inventar seus fins sem auxílios. (BEAUVOIR, 2016a, p. 17)
\end{abstract}

$\mathrm{Na}$ estruturação dos romances aqui estudados demarcando o ponto de vista da narrativa, principalmente através da voz que narra, há a insurgência de uma narradora que se constrói através de uma negociação entre a ideologia patriarcal e a ideologia feminista que lhes são contemporâneas, sem no entanto que uma prescinda da outra, uma vez que não se evidencia uma ruptura total, o que resultaria em uma transformação de fato revolucionária; tampouco significa uma ilusão total, uma vez que "alguém que fosse totalmente vítima da ilusão ideológica sequer seria capaz de reconhecer uma reivindicação emancipatória sobre si" (EAGLETON, 1997, p. 13). Em ambos os contextos aqui analisados haverá a coincidência de atuação dessas duas ideologias que, em se desenvolvendo dialeticamente, resultam mais numa tentativa de persuasão do que de fato ruptura, principalmente porque as mulheres que farão eco às reivindicações feministas, do que convencionalmente chamamos de primeira onda feminista, são elas próprias, de maneira geral, privilegiadas no acesso social e político que têm e tentarão uma negociação com o que já está consolidado, também objetivando que não haja retrocesso naquilo que parece lhes estar assegurado.

Mészáros indica a complexidade de que se traveste a ideologia dominante naquilo que reverbera enquanto valor e que atuará, também, no sentindo de fazer a 
sua própria manutenção, estabelecendo uma dinâmica em que tais valores serão reforçados mesmo por aqueles que os questionam:

O poder da ideologia predominante é indubitavelmente imenso, mas isso não ocorre simplesmente em razão da força material esmagadora e do correspondente arsenal político-cultural à disposição das classes dominantes. Tal poder ideológico só pode prevalecer graças à vantagem da mistificação, por meio da qual as pessoas que sofrem as consequências da ordem estabelecida podem ser induzidas a endossar, "consensualmente", valores e políticas práticas que são de fato absolutamente contrários a seus interesses vitais. (MÉSZÁROS, 2012, p. 472)

Assim, ainda que haja certa disputa ideológica, seria inevitável, tendo em vista a condição material que podemos observar através da perspectiva histórica, a presença de uma significativa contradição que será sentida porque por um lado irá ratificar o que é hegemônico e por outro prospectar diretrizes que incidem sobre essa hegemonia, sem, no entanto, esvaziar ficticiamente as condicionantes ideológicas:

Prever o "fim da ideologia" ou atribuir uma conotação apenas negativa a toda ideologia sempre foi algo totalmente irrealista e continuará sendo por um longo período histórico. É inconcebível que as ideologias "murchem" por si e, muito menos, que sejam ficticiamente "superadas" no âmbito fechado de construções teóricas pseudo-científicas - enquanto existirem conflitos sociais importantes com os quais estão inextricavelmente interligadas. (MÉSZÁROS, 2012, p. 109)

Uma vez definidas à maneira advertidamente resumida as ideologias ou a ideologia e a contraideologia que investigaremos na narradora, passemos então para as implicações entre o conceito de ideologia e a literatura. 


\section{Literatura e Ideologia}

A preocupação no entrecruzamento entre literatura e história segue uma perspectiva materialista presente nesta tese, através da qual se procura analisar os romances naquilo que, numa elaboração que pressupõe forma e conteúdo, irá investigar a conformação das vozes narrativas perante a categoria gênero, prioritariamente, ainda que, sob o ponto de vista da ideologia, a crítica clássica materialista se preocupe quase que exclusivamente com a categoria classe. Para tanto, tomamos por base os estudos sobre ideologia na literatura, partindo do pressuposto de que subjaz em todo texto certa dimensão ideológica:

A significação, na sua definição mais certa, é a relação que se opera entre expressão e conteúdo (segundo a terminologia de Hjelmslev) ou entre o significante e o significado (segundo a terminologia de Saussure); na medida em que o referente (o objeto) Ihe é exterior, a formação ideológica apaga-se no momento de produção; por outro lado, sabemos que a produção, sendo um processo, não pode entender-se em termos de momento, de isolamento pontual no tempo, e sabemos também que um conteúdo inclui valores que se estruturam não apenas segundo uma forma textual mas também segundo uma forma social - e esses são já elementos da ideologia; o que é preciso sublinhar é que, enquanto operação, a significação é um mecanismo estritamente linguístico, semiológico, textual (de acordo com os vários níveis de trabalho), mas que, por outro lado, enquanto sentido de escrita ou de leitura, ela é já transformação de dados e, por conseguinte, veículo de ideologia. (BALIBAR et al., 1976, p. 12)

Se o texto é veículo de ideologia e se, portanto, nele irão incidir os campos hegemônicos que atuam na esfera social, consequentemente terá em seu invólucro também a contradição que paira sobre esses campos e que com eles irão atuar:

O texto produzido em condições que o representam como uma obra acabada que manifesta uma ordem essencial que exprime um projecto subjectivo ou o espírito de um tempo em relação aos quais 
nos podemos identificar desde logo numa leitura sábia ou ingênua. Mas em si mesmo o texto não é nada disso, pelo contrário, é materialmente incompleto, díspar, incoerente, porque resulta da eficácia conflitual, contraditória, de um ou de vários processos reais sobrepostos que nele não desaparecem, salvo de maneira imaginária. (BALIBAR et al., 1976, p. 36)

Ao se pensar os processos reais sobrepostos, debatemo-nos necessariamente com o problema da perspectiva do romance realista, que rege as estruturas narrativas aqui analisadas. Os romances de Lúcia Miguel Pereira e Maria Lamas estão geridos sob as bases realistas da literatura, que pressupõem a representação social, ainda que, obviamente, em se tratando de representação não será um mero reflexo da realidade, senão uma realidade transformada à medida que interessa para a criação ficcional:

Depois é, de novo, uma definição da literatura em geral: toda a literatura seria realista de uma maneira ou de outra, representação da realidade, mesmo e sobretudo quando dá da realidade uma imagem que não é a percepção imediata, quotidiana, comum a todos. As "margens" do realismo podem então alargar-se infinitamente. (BALIBAR et al, 1976, p. 41)

Em seu livro, Marxismo e Teoria da Literatura, Lukács aplica-se em um dos capítulos na discussão do problema da perspectiva. Muito embora ali tenha se dedicado a diferenciar especialmente o que chama de realismo crítico e realismo socialista, apontando os problemas enfrentados por este último que tende a manifestar a perspectiva como realidade, o teórico húngaro apresenta-nos sumariamente a questão da perspectiva naquilo que a estipula entre a realidade e a utopia. Interessa, particularmente para este estudo, as três definições sobre perspectiva de Lukács. Em seus termos:

Em primeiro lugar, uma coisa é determinada como perspectiva na medida em que ainda não é existente. Se existisse, não seria perspectiva para o mundo que representamos. 
Em segundo lugar, contudo, esta perspectiva não é uma mera utopia, um mero sonho subjetivo, mas sim a consequência necessária de uma evolução social objetiva, que se manifesta objetivamente, no plano literário, através do desenvolvimento de uma série de personagens agindo em determinadas situações.

Em terceiro lugar, ela é objetiva, mas não fatalista. Se o fosse, não seria uma perspectiva. É perspectiva na medida em que ainda não é realidade; é, na verdade, uma tendência a realizar nos fatos esta realidade, de uma grande tendência social, que se realiza por caminhos intrincados, talvez de um modo muito diferente do que aquele que imaginamos. (LUKÁCS, 2010, p. 287) ${ }^{27}$

Temos, dessa forma, que a perspectiva, aos moldes de Lúkacs, aponta para uma realidade objetiva sem que nela se empenhe totalmente, uma vez que também é tangenciada por certo teor utópico no sentido de prospectar. Embora saibamos dos riscos de descontextualizar o debate teórico realizado por Lukács, principalmente porque aqui os romances analisados não coincidem com a defesa que faz do realismo crítico (prescindindo, por exemplo, da noção de totalidade que aponta em Tolstoi), parece-nos esclarecedor esse ponto limiar entre realidade objetiva e utopia da perspectiva para iluminar a questão da ideologia nas vozes narrativas aqui estudadas.

Faz-se necessário então trazer à luz a perspectiva enquanto subjacente à "ação ideológica" que se manifesta na representação da realidade, o que deliberaria os limites de prospecção da perspectiva:

No âmbito específico da criação artística, por outro lado, a ação da ideologia mantém uma característica essencial que se manifesta na representação da realidade, na construção do conhecimento, em geral: a ideologia atua também - e talvez sobretudo - na limitação dos horizontes; se manifesta, possivelmente, mais no que não está

\footnotetext{
${ }^{27}$ Lukács terá como grande exemplo do realismo crítico Tolstoi de Guerra e Paz, no qual, segundo o teórico, o problema da perspectiva é tratado de maneira "historicamente profunda e artisticamente expressa de modo admirável". Segundo o que podemos depreender da análise lukaciana, em Tolstoi a perspectiva só "é autêntica e concreta" porque "surge das tendências de desenvolvimento dos indivíduos representados na obra de arte - e não quando é justaposta como verdade social objetiva a determinados homens que têm com ela apenas uma tênue ligação social" (LUKÁCS, 2010, p. 288).
} 
sendo visto do que naquilo que está sendo exagerado. (KONDER, 2002, p. 223)

Partindo das premissas aqui apontadas, cabe agora nos atermos para a ideologia patriarcal e a ideologia feminista que se consolidam nas narrativas, apontando para a perspectiva baseada, simultaneamente, na realidade e em uma prospecção futura.

\section{Ideologia patriarcal e ideologia feminista nas estruturas narrativas: o casamento}

Para que possamos prosseguir nossa análise, tendo como ponto de vista a questão da ideologia determinando as vozes narrativas, torna-se imprescindível que façamos um apanhado histórico dos contextos sob os quais os romances de Lúcia Miguel Pereira e Maria Lamas foram produzidos. Portanto, tentaremos delimitar a ideologia patriarcal e a feminista presentes nos romances a partir da perspectiva histórica, que permite adensar o conjunto de ideias que operavam sobre a sociedade brasileira e a portuguesa nos anos 1930.

No entanto, é importante ressaltar, como se procurou demonstrar nas análises até aqui realizadas, que há um assunto fundamental e em comum nos romances: 0 casamento. O casamento será, então, foco das narrativas, num primeiro momento, nas duas publicações do início dos anos 1930, através do embate de mulheres que, uma vez casadas, passam a ter consciência da restrição de suas liberdades dentro do casamento, através de uma determinação social que lhes atribui com caráter exclusivo $^{28}$ a função de esposas e mãe; e no final dos anos 1930, com protagonistas que não se casam, e que no limite de suas especificidades renunciam ou recusam o casamento. Justamente sobre o casamento (que determinará a formação da família) também irão incidir as forças da ideologia patriarcal e da

\footnotetext{
${ }^{28}$ Reiteramos que nos referimos aqui a uma classe social específica, de mulheres burguesas, ou educadas sob os preceitos burgueses, brancas, e partícipes das rodas de certa elite econômica. Para as trabalhadoras do mesmo período, que serviam como força de trabalho barata, as atribuições não se restringiam a essa função, ainda que também tivessem que cumprir essa função uma vez que sobre elas recaíam os encargos domésticos e a educação dos filhos.
} 
ideologia feminista do período, pois, como eixo fundamental na condição da mulher, será apreciado ou contestado.

A questão do casamento vai ser fulcral para o debate feminista, tanto nos anos 1920-1930, quando os papéis da vida conjugal passam a ser questionados, quanto num feminismo sob o qual se dará a segunda onda, consolidada a partir dos anos 1960, que tem como precursora (além das feministas do período anterior) Simone de Beauvoir, com o seu Segundo Sexo, publicado em 1949. Neste livro, sobre o casamento pontua:

O destino que a sociedade propões tradicionalmente à mulher é o casamento. Em sua maioria, ainda hoje, as mulheres são casadas, ou o foram, ou se preparam para sê-lo, ou sofrem por não sê-lo. É em relação ao casamento que se define a celibatária, sinta-se ela frustrada, revoltada ou mesmo indiferente ante essa instituição. (BEAUVOIR, 2016, p. 187)

O casamento, portanto, permanece como ponto central nas discussões e reivindicações dos movimentos feministas, tal qual já se fazia sentir desde o final do século XIX e será elemento importantíssimo nas estruturações das narrativas nesta tese analisadas. Passemos a seguir a analisar as especificidades do Brasil e de Portugal sobre a condição de vida da mulher para que melhor possamos observar as ideologias presentes nessas narrativas. Ainda é importante apontarmos que se haverá disputa no campo ideológico, a ideologia patriarcal é englobada pela burguesa, e as ações de oposição feminista do período serão, a um só tempo, de oposição à patriarcal, mas apenas à medida que isso não afete dramaticamente a outra, burguesa, classe a qual pertenciam as principais feministas do período, senão também a maioria das protagonistas dos romances. Por isso, a disputa na questão da função social da mulher, em sendo seu papel desempenhado em família, se tornou tão cara à modernização que deveria acompanhar novos influxos sociais, mas desde que não ocasionasse ruptura com a dinâmica familiar, uma vez que ela também assegurava a hegemonia burguesa e, por isso, era defendida até pelo Estado. 


\section{Papel social da mulher na sociedade de mentalidade patriarcal}

As mulheres retratadas nos romances de Lúcia Miguel Pereira e de Maria Lamas na década de 1930 são mulheres burguesas, à exceção, conforme procuramos demonstrar em nossa análise, de Maria Aparecida (Amanhecer), vivendo no cerne de uma família nuclear de mentalidade patriarcal, à exceção aqui de llonka. A fim de esclarecer esta configuração que elucida o que se supõe como papel da mulher enquanto mãe e esposa, faz-se necessário apontar as especificidades desta condição, a princípio como condição geral, para depois interpretá-las nos limites das suas nacionalidades a partir das configurações dos contextos históricos em que se consolidam. Dessa forma, torna-se relevante que apontemos para as diretrizes desse estado das coisas no que concerne a disputa entre diversos campos para entendermos a dinâmica que incide sobre as estruturas dos romances estudados.

A concepção da família nuclear surge a partir da ascensão da burguesia, mais especificamente no século XVIII europeu. Tendo papel fundamental no sistema capitalista, seu objetivo é principalmente assegurar o acúmulo de bens através da hereditariedade. Engels, em seu A origem da família, da propriedade privada e do Estado, desenvolve tese sobre as transformações na instituição familiar a partir de dois eventos principais, a divisão do trabalho e a propriedade privada. Tais fenômenos transformaram as relações familiares e seus efeitos, resumidamente, para a mulher, são o confinamento ao lar, no trabalho doméstico, trabalho este que perde sua importância em detrimento do trabalho produtivo social que o homem passa a desenvolver com exclusividade:

A divisão do trabalho da família havia sido a base para a distribuição da propriedade entre o homem e a mulher. Essa distribuição do trabalho na família continuava sendo a mesma, mas agora transtornava as relações domésticas, pelo simples fato de ter mudado a divisão do trabalho fora da família. (ENGELS, 1985, p. 182)

Embora a família tenha papel decisivo na constituição do capitalismo, o patriarcado, como vem sendo demonstrado por diversos estudos, não será 
resultado deste, senão também apropriado por este. Assim, há duas vertentes que importam na manutenção da família, segundo Bruschini (1990), que irão atuar vias de regras em todas as restruturações sociais que se passaram desde o seu surgimento: a manutenção da noção de hierarquia, que é constituída dentro do grupo familiar numa reflexão ideológica que encontrará sua força nas relações em sociedade, por um lado, e a manutenção de certo padrão econômico determinado, pela divisão social do trabalho entre os sexos, através do qual a mulher não só teria a função na educação da prole como também de exercer a atividade doméstica necessária sem que isso requeresse remuneração.

No Brasil, no entanto, os estudos sobre a família apontam para a relevância que essa instituição tinha na elaboração das diretrizes e do controle do Estado. Embora a conjuntura patriarcal, que englobava a família, a parentela, os escravos e os prestadores de serviço nas mãos decisórias do senhor comece a sofrer transformação no século XIX, com a chegada da corte portuguesa no Brasil, é notório que nas novas configurações que vão se precipitando permanece, em detrimento de certa limitação de poder do patriarca e uma nova configuração majoritariamente relacionada à família nuclear, um controle sobre a mulher. Isso implica na afirmativa de que no Brasil "o capitalismo não gera o patriarcado, mas o utiliza e reforça, fazendo-o parte de sua dinâmica", conforme nos aponta Bruschini em seus estudos sobre Maria Valéria Pena ${ }^{29}$ (1990, p. 51):

\begin{abstract}
Pena vai mais além, lembrando a cumplicidade do Estado, que controlar a participação feminina no trabalho coletivo em nome dos interesses da família, reforçando dessa maneira, através da legislação sobre o casamento da taxação e da previdência social, a divisão sexual do trabalho e reafirmando o papel materno e doméstico das mulheres. (BRUSCHINI, 1990, p. 51)
\end{abstract}

Dessa forma, ainda que fatores econômicos englobem a atuação da mulher nessa dinâmica e sirvam, também eles, para restringirem as liberdades femininas, não é só devido a isso que se estabelece tal controle. Como nos indicam diversas estudiosas feministas deste assunto, o poder masculino opera através, principalmente, de uma ideologia hegemônica que servirá para manter a ordem de

\footnotetext{
${ }^{29}$ Referente ao livro Mulheres e trabalhadoras: presença feminina na constituição do sistema fabril.
} 
uma sociedade em transformação, uma vez que "as relações autoritárias que se desenvolvem no interior da família articulam-se dialeticamente com o autoritarismo social" (Bruschini, 1990, p. 55).

Chamamos aqui de sociedades de ideologia patriarcal aquelas que pressupõem na dinâmica da relação familiar o poder do homem nas decisões sobre a família, o que inclui a esposa, uma vez que é ele quem controla suas fontes de sobrevivência. Se é verdade que nas ornamentações dos anos 1930 esse poder já sofreu, de alguma forma, enfraquecimento, principalmente no que tange a autoridade paterna sobre a vida dos filhos e agregados, o que também possibilitou um arrefecimento das forças de controle sobre a mulher uma vez que esta passa a ter maior participação na vida social das cidades, cenário principal das novas configurações da família, também é verdade que novas formas de controle vão se formatando. Assim, a mulher irá exercer um papel social, ainda que desempenhe alguma atividade econômica fora do lar, secundarizado, devido à incapacidade civil que lhe é legada, conforme nos explica Heleieth Saffioti:

A felicidade pessoal da mulher, tal como era então entendida, incluía necessariamente o casamento. Através dele é que se consolidava sua posição social e se garantia sua estabilidade ou prosperidade econômica. Isto equivale a dizer que, afora as que permaneciam solteiras e as que se dedicavam às atividades comerciais, as mulheres, dada sua incapacidade civil, levavam uma existência de dependência de seus maridos. $\mathrm{E}$ a asserção é válida quer se tomem as camadas ociosas, em que a mulher dependia economicamente do homem, quer se atente para as camadas laboriosas, nas quais a obediência da mulher ao marido era uma norma ditada pela tradição. Sob a capa de uma proteção que o homem deveria oferecer à mulher em virtude da fragilidade desta, aquele obtinha dela, ao mesmo tempo, a colaboração no trabalho e o comportamento submisso que as sociedades de família patriarcal sempre entenderam ser o dever da mulher desenvolver em relação ao chefe de família. (SAFFIOTTI, 2013, p. 63)

O casamento então permanece sendo elemento fundamental e definidor na condição de vida da mulher, uma vez que dele ainda depende o seu 
desenvolvimento social. A mulher casada deixa de estar sob o poder do pai para submeter-se ao poder do marido, mas é através do seu acondicionamento na esfera familiar que alcançará alguma forma de autonomia. Assim, será assinalado a este caráter de dependência que evoca a submissão ao mesmo tempo em que elabora uma nova forma de participação social o que Michelle Perrot chamou de moral doméstica, ao analisar a mulher na sociedade europeia (francesa) do século XIX:

Bonnie Smith mostra como as burguesas do Norte da França, excluídas, depois de 1860, da gestão dos negócios a que até então estavam associadas, retiradas em suas belas casas doravante afastadas do perímetro da fábrica, administram seus interiores, a numerosa família e a criadagem, edificando uma moral doméstica coerente, que dá sentido às suas menores ações. A fé contra a razão, a caridade contra o capitalismo e a reprodução como justificativa fundamental constituem os eixos principais dessa moral. (PERROT, 1988, p. 181)

No que concerne à mulher burguesa, nos alerta ainda Perrot (1988, p. 215), em análise do mesmo período, que essas seriam confinadas ao lar, numa rigidez que se diferenciava das mulheres trabalhadoras: "As mulheres burguesas têm um modo de circulação muito mais precocemente rígido, uma relação interior/exterior muito regulada, um ritual de "saída" e de recepção muito refinado". Tanto no Brasil, como em Portugal, nos anos 1930, estava ainda assegurada a ideologia patriarcal imperando sobre a atuação da mulher no campo social, o que impedia uma autonomia feminina. No entanto, com a abertura que se tornou possível através das significativas mudanças sociais que se operaram também nesses países, novos questionamentos foram infligidos a partir do ponto de vista feminino acerca das limitações de que as mulheres estão cercadas. É verdade que a resistência sempre existiu e que ações pontuais e não organizadas ficam apagadas nas pegadas históricas em que também forças ideológicas operam, no entanto, nos anos 1930 (bem verdade, a partir dos anos 1920) surgem as primeiras movimentações organizadas que darão força ao que se chamou de primeira onda (em Portugal, primeira vaga) feminista. 
Em dimensões ideológicas, apesar das intensas transformações na vida da mulher no início do século XX, tanto no Brasil como em Portugal, a diretriz da configuração da família terá uma sensível atuação para a manutenção do modelo esposa e mãe, conforme nos aponta Bruschini:

Nesse modelo cabe à mulher apenas ser esposa, dona-de-casa e sobretudo mãe, papel esse cuja importância se acentua e especializa, na medida em que seu desempenho passa a se basear em conhecimento científicos, como os que foram sendo acumulados pelas Psicologia. (BRUSCHINI, 1990, p. 54)

Tem-se então o cenário ideal que parece estruturar os romances de Lúcia Miguel Pereira e Maria Lamas, em que ocorrerá uma dialética entre um conservadorismo que busca manter a ordem e as reivindicações dessa onda que vem organizada através de movimento das mulheres. Assim, as protagonistas responderão a essa dialética e as narradoras, em nossa leitura, serão constituídas a partir dessa dialética. Para tanto, é necessário que observemos como isso sobreveio em cada um dos países, a fim de melhor entendermos as coadunações que aproximam e/ou distanciam esses romances entre si.

\section{A mulher e a história: o Brasil dos anos 1930}

Há, como sabemos, nos primeiros decênios do século XX no Brasil, uma desestabilização da ordem, devido às novas configurações sociais que vão se conformando, que estão intrinsecamente correlacionadas às diretrizes que são dadas ao papel social da mulher em sua função de mantenedora da ordem privada $^{30}$, qual seja sua função de mãe e de esposa. A partir da decadência da elite agrária, ocorre o que Mary Del Priore definiu como a "desestruturação da família tradicional brasileira", que incidirá especificamente na instituição casamento:

\footnotetext{
${ }^{30}$ As delimitações entre o privado e o público são problemáticas, uma vez que por vezes dissolvem arbitrariamente o que é indissolúvel. No entanto, aqui buscamos apontar para a ordem privada aquilo que se refere a organização familiar nos limites do lar, o que era, na época para a ordem que se apregoava inclusive em termos de organização do Estado, o lugar imputado à mulher.
} 
Nas primeiras décadas do século $\mathrm{XX}$, toda ameaça ao casamento era alvo de críticas. O tema do divórcio, por exemplo, era considerado "imoral"; "a pior chaga da sociedade"; "só em casos excepcionais e depois de rigorosíssimo processo". (DEL PRIORE, 2015, p. 240)

Isso acontece devido ao notável movimento de questionamento, por parte das mulheres, das opressões que sofriam dentro do casamento, a partir das imposições de maridos autoritários que mantinham poder civil sobre elas, tanto no que se refere aos fatores econômicos como aos fatores jurídicos. Esta autoridade, aqui, estava acondicionada também na ideologia patriarcal, que, se havia perdido o poder em outras esferas, visava mantê-lo sobre o corpo e a vida da mulher. Ressaltamos, ainda, que havia, nessa concepção, uma mentalidade patriarcal emoldada por subterfúgio ideológico que será significativa no que tange o papel da mulher. É Maria Cecilia de Souza que ilumina esta questão, ao analisar a pesquisa de Ângela Mendes de Almeida acerca das conjunturas que vão se formatando no Brasil a partir da industrialização e urbanização, quando são arrefecidos os antigos moldes da família patriarcal:

Ângela Mendes de Almeida tenta elaborar uma possível resposta a este problema, quando argumenta que a imposição de valores da burguesia industrial europeia, veiculada por diferentes discursos, encontrou no Brasil uma mentalidade patriarcal fortemente enraizada. Essa mentalidade resistiu à imposição, domesticou valores, até colocá-los a seu serviço. Segundo o que se pode depreender de sua análise, a mentalidade patriarcal absorveu a mistificação da mulher e seu destino doméstico, na perspectiva porém de um objeto propriedade do marido. Incorporando a moral sexual da família burguesa, reservou-a no entanto às mulheres, mantendo a poligamia masculina. Formalmente dando dignidade ao valor trabalho, conservou, entretanto, a depreciação do trabalho manual, antes próprio do escravo, agora de mulheres e das classes subalternas. Assimilou a noção de afeto conjugal, mas condicionando-o à noção de favor, em que momentaneamente se distinguia inferiores para coloca-los como iguais, mas sem renunciar 
à alternativa da brutalidade simples, quando desigual percebia 0 favor como um direito. (SOUZA, 1999, p. 176)

Estabelece-se, a essa maneira de readequação perante novas demandas, um confronto direto entre uma nova ordem que vai se configurando devido ao movimento dos novos tempos, cujo influxo se revela através dos meios de comunicação, principalmente, e das necessidades do mercado em abrir novos campos consumidores dos quais as mulheres eram alvo, e a tentativa de manutenção de certa ordem tradicional ancorada na ideologia patriarcal. Sobre isso, nos esclarece ainda Besse:

Enquanto a modernização e o embelezamento dos centros urbanos que proliferavam exibiam riqueza acumulada e progresso tecnológico, as imagens das moças independentes que trabalhavam fora e das melindrosas sensuais simbolizavam a mudança nas relações sociais. Fascinante ainda que assustadora, a "moça moderna" foi, ao mesmo tempo, exibida com orgulho, como demonstração do progresso nacional, e denunciada como ameaça à tradição nacional. Sua autonomia, segurança e realizações educacionais e profissionais cada vez maiores correspondiam às novas liberdades, à ética burguesa e às necessidades econômicas da sociedade urbano-industrial brasileira em expansão. Mas sua metamorfose a partir da matrona corpulenta e isolada do século XIX requeria redefinições incômodas das relações homem-mulher, dos papeis masculinos e da organização familiar, bem como do comportamento feminino "adequado". Os críticos temiam que as que cultivavam a nova imagem da mulher independente, ousada e sexualmente provocante, sofreriam uma revolução de consciência que ameaçaria profundamente a família; temia-se também que as mulheres não pudessem abraçar a moralidade do mercado sem que isso levasse o "materialismo" a triunfar sobre os "valores humanos" na esfera pessoal. (BESSE, 1999, p. 37; 40)

Há então um embate no que tange o papel social da mulher, numa sociedade que se moderniza através de um processo de transfiguração de ideologias em que operam, simultaneamente, o que coaduna com essa modernização e o que tenta 
fazer uma manutenção da ordem antiga, processo chamado de "modernização da desigualdade" por Susan Besse (1999). Em sua perspectiva, das mulheres do período iniciado na década de 1920 no Brasil é exigido uma veste de modernidade que não abdicasse, no entanto, da representação de papéis estipulados para suas atuações, ao mesmo tempo em que eram rechaçadas aquelas que de fato assumissem a modernidade. Exigia-se, portanto, que a mulher não fosse nem a representação do antigo paradigma nem a do novo:

As mulheres que deixassem de adquirir um verniz de modernidade eram submetidas ao ridículo e ao ostracismo social, enquanto as que levavam a sério as mensagens que transmitiam a possibilidade e a desejabilidade da emancipação social, econômica e sexual das mulheres ou eram encaradas como imorais ou estereotipadas como briguentas, feias e velhas. Esperava-se que as mulheres cultivassem uma aparência exterior de sofisticação moderna e ao mesmo tempo conservassem as "eternas" qualidades femininas de recato e simplicidade. (BESSE, 1999, p. 40)

A esse processo parece corresponder, em certa medida, Maria Luísa, enquanto que, dialeticamente, vai correspondendo a isso em forma crítica negativa ou positiva a narradora, como procuramos demonstrar. A narradora de Maria Luísa portanto assume ao mesmo tempo o verniz moderno, sem prescindir, simultaneamente, de criticá-lo, enquanto aponta para o manutenção da ordem, ainda que com isso também estabeleça uma crítica.

Neste processo de modernização que, no entanto, prescinde de arrogar uma igualdade entre os sexos, há uma exigência sobre a mulher que demarca uma ruptura com seus antigos posicionamentos, o que irá ocasionar, como já mencionamos, um questionamento significativo traduzido também em termos de movimentação das mulheres do período com relação ao casamento. Ainda assim, o que abriu caminho para que surgissem com força de movimento esses questionamentos foi o acesso das mulheres à educação formal, o que ocorreu, a princípio, para que melhor cumprissem seu papel de mãe no que tange nortear a primeira educação dos filhos. Tal processo vinha acontecendo desde a segunda metade do século XIX e apresentou resultados expressivos nas primeiras décadas 
do século seguinte, arrefecendo significativamente a estrutura patriarcal tal qual se apresentava até então:

Depois de as instituições de ensino superior serem abertas às mulheres, em 1879, apenas umas poucas se candidataram, dados 0 alto custo para se obter a educação secundária necessária e os fortes preconceitos sociais contra esse tipo de novidade. Não obstante, as aspirações das mulheres se elevavam e as realidades sociais mudavam à medida que as famílias de classe média urbana buscavam mais educação para suas filhas, não só com o fito de prepara-las para papeis familiares mas para garantir que pudessem ganhar honradamente a vida, se e quando isso se tornasse necessário. (...) Em meados da década de 1910, dezenas de anos de desgaste do poder patriarcal já haviam tornado obsoletas a organização tradicional da família da elite e as definições de gênero. Como instituições extrafamiliares haviam assumido muitas das funções da família patriarcal extensa, esta foi sendo gradualmente substituída pelo modelo da família nuclear burguesa urbana. (BESSE, 1999, p. 19)

É no cerne desta família nuclear burguesa que assistiremos os desenvolvimentos das protagonistas das narrativas aqui estudas de Lúcia Miguel Pereira nos anos 1930. No entanto, é importante que notemos que a mudança de foco narrativo assim como a mudança no lugar social da personagem irá prospectar nos romances as mudanças sociais que visivelmente eram parte daquele contexto, apontando para uma alternância da ordem a partir do questionamento da instituição que deveria mantê-la, a família. No que tange a questão feminina nos romances, é fundamental notarmos que essa ordem será questionada a partir da relação que é estabelecida através do ponto de vista sobre o casamento, que será, ao mesmo tempo, a expressão de manutenção da ordem e alvo de questionamento devido às injustiças a que estavam sujeitas as mulheres.

Na década de 1920, havia uma concordância generalizada entre as comunidades intelectuais e profissionais do Brasil quanto ao fato de 
que o casamento e a família estavam em "crise"; e havia muitos que temiam a sua rápida extinção.

Não obstante, aumentara o sentimento de injustiça por parte das mulheres, elas haviam conquistado uma voz e descoberto que podiam ter lugar pelo poder na esfera pública. Assim, subitamente, a insubordinação e rebeldia das mulheres tornou-se um tema socialmente importante, mais do que uma questão privada que pudesse ser manipulado silenciosamente por trás das portas fechadas do lar.

Tornou-se comum as mulheres compararem a instituição do casamento a uma prisão. (BESSE, 1999, p. 41; 43-44; 45)

A partir de então, com as novas diretrizes da "vida moderna" que pressupunham novas formas de atuação da mulher, a família entra em crise. Segundo Bruschini:

Expostas aos novos valores, devido a seu acesso à educação e ao trabalho, as mulheres pela primeira vez começam a questionar o casamento e o lar que as sufoca. Mas, diante desta crise da família e do casamento, uma nova propaganda se encarrega de persuadir a vida doméstica. À medida que os entraves sociais e econômicos para a participação da mulher caem, reforçam-se os constrangimentos ideológicos. (BRUSCHINI, 1990, p. 66)

No que se remete às diferenciações de classe, as mulheres mais pobres, ainda que sujeitas à mesma ideologia patriarcal, serão tangenciadas por um outro repertório histórico, que se volta para a exploração de um trabalho desvalorizado com relação ao homem, algo observável no Brasil até a atualidade, ainda que essas mulheres mais pobres dispusessem, por suas condições econômicas, de uma maior flexibilidade com relação, principalmente, ao casamento. Assim sendo, para a mulher pobre no início do século XX, o casamento legal ainda era inacessível, uma vez que sua realização era cara: 
O casamento legal era sinal de status que os pobres raramente alcançavam. Para os que não tinham bens a defender, as uniões consensuais constituíam a norma, as taxas de ilegitimidade eram altas e as famílias dirigidas por mulheres eram muito comuns. A indolência e o isolamento feminino eram ideais impossíveis. Desde muito jovens, as mulheres pobres trabalhavam em ocupações manuais humildes (como empregadas domésticas, cozinheiras, amas-secas, lavadeiras, costureiras, vendedora ambulantes e, às vezes, prostitutas) para a duras penas manter uma existência marginal. E não só o seu trabalho as introduzia nos espaços públicos mas também sua renda - ainda que pequena - Ihes proporcionava certo grau de autonomia. (BESSE, 1999, p. 15)

Essa autonomia, por não ter bens a defender, parece estar implícita na narradora de Amanhecer, o que Ihe permite, por exemplo, a fuga do modelo familiar ao qual havia sido moldada para representar. No entanto, é importante definirmos que se Maria Aparecida pode por uma via alçar voos rumo a uma maior independência do que a que é representada por sua mãe, por exemplo, ela ainda irá estar acorrentada à ideologia patriarcal que lhe roga isolamento social por fugir à ordem imposta como seu papel. Outro fator relevante é o fato de que, diferente das mulheres pobres referidas nesses estudos que tinham pouco acesso, vias de regras, à educação, principalmente na primeira década do século, Maria Aparecida estuda e, por isso, adquire certo grau de instrução que lhe permite questionamento e que vai the abrir espaço para desenvolvimento de uma vida intelectual, em certa medida, autônoma. A partir disso, irá questionar não só o casamento, como também a ordem familiar, a ordem burguesa e a atuação falsamente libertária de Antônio.

Ainda assim, embora a recusa ao casamento não fosse uma realidade para grande parte das mulheres das elites brasileiras, há uma conjunção de fatores que associados às novas organizações sociais e respondendo fortemente à ideologia patriarcal, passam a ser questionados pelas mulheres, principalmente o desempenho do papel masculino dentro da configuração conjugal. Nesse sentido, o casamento passará a ser alvo de críticas e questionamentos:

Era indisfarçável o conformismo da maioria das mulheres diante da condição de sujeição imposta pela lei e pelos costumes: serva do 
marido e dos filhos, sua única realização aceitável acontecia no lar. Sua família, como já disse uma historiadora, era "ninho e nó" ao mesmo tempo. Ninho, pois proteção contra agressões externas, muro contra a invasão de sua privacidade. Mas nó porque secreta, fechada, exclusiva e palco de incessantes tensões. (DEL PRIORE, 2015, p. 248)

Se por um lado, as mulheres desenvolvem um movimento que é capaz de questionar o casamento, por outro haverá um fortalecimento ideológico para a manutenção do mesmo, uma vez que o casamento garantia a ordem familiar, e esta, por sua vez, era considerada a principal mantenedora da ordem social numa sociedade em transformação. Dessa maneira, haverá uma reação aos novos questionamentos que vão se figurando, no sentindo de conter a insatisfação feminina:

As mudanças que o novo século e a "vida moderna" impunham causaram, por sua vez, reações. Uma sólida barreira feita de opiniões de juristas, médicos e da própria opinião pública reagia a tudo o que pudesse ferir as instituições básicas da sociedade, sobretudo a imagem da família e do casamento. (DEL PRIORE, 2015, p. 252)

Para assegurar a ordem a partir da formação familiar e do casamento, mudanças ocorreriam no paradigma de comportamento masculino dentro da relação, na conformação do casal moderno, no entanto, às mulheres ainda seria atribuído ao casamento a exclusividade de via de subsistência, num reforço da ideologia que pressupõe que a recusa ao casamento seria ainda mais desvantajosa do que qualquer desvantagem que o casamento pudesse ocasionar e que vinha sendo questionada no período:

As mulheres eram então persuadidas de que não casar era um insucesso. Fazia-se a diferença entre a solteirona - rejeitada para o casamento - e a solteira, ainda não escolhida, mas casável. "Cair no barricão" designava "ficar para tia". Pior. Era uma forma de descensão social, que deprimia as moças maduras. Só lhe restava 
amores ridículos e socorro sobrenatural graças às esmolas (...). (DEL PRIORE, 2015, p. 254)

Para tanto, será também reforçada, à base da ideologia patriarcal, o papel proclamado para a esposa, em resposta às reclamações que essas, cada vez mais, e principalmente através da imprensa, vinham fazendo ao casamento. $O$ que significa que em contrapartida à insatisfação da mulher devido aos desmandos do marido, que sobre si tinha a autoridade civil e jurídica, serão reforçados valores que atribuem a ela o sucesso da relação:

Nesse quadro - explicam as historiadoras Maria Lúcia Mott e Marina Maluf - a esposa virtuosa era aclamada e cercada por comandos morais. Prescreveu-se para ela complacência e bondade, para prever, satisfazer e até adivinhar desejos do marido; dedicação para compartilhar abnegadamente com ele os deveres que encerrava o casamento; paciência para aceitar suas fraquezas de caráter. (...) $\mathrm{O}$ importante era fortalecer as relações, afastando o risco do temido e vergonhoso divórcio. (DEL PRIORE, 2015, p. 254)

Norteados dessa forma, temos que os novos rumos, ancorados numa ideologia ainda muito fortalecida, serão acondicionados em duas restrições que visam manter a mulher em seu papel de mãe e esposa: a manutenção do casamento como primordial à vida feminina por um lado e, por outro, a resistência à possibilidade de divórcio quando a insatisfação se tornava extremamente sensível numa confabulação da vida da mulher; resistência essa já bastante edificada à base da dependência econômica que era arrogada a maioria das mulheres de certa camada social:

A grande ameaça que pairava sobre as esposas, como já visto, eram as separações. Além do aspecto efetivo, as necessidades econômicas - pois a maioria das mulheres de classe média e alta dependia do provedor - e do reconhecimento social - as separadas eram malvistas - pesavam a favor do casamento a qualquer preço. (DEL PRIORE, 2015, p. 294) 
Pressupõe-se que se a única possibilidade de realização feminina era o casamento e, em caso de insatisfação, a ruptura do casamento estava cerceada, ao nível ideológico e jurídico, uma vez que muitos foram os divórcios recusados no período como nos aponta Maria Cecília Cortez de Souza em seu estudo Crise familiar e contexto social (1999), pela desvalorização da vida social e econômica da mulher, o adultério surge como ameaça imanente. E se tornará, também ele que sempre foi aceito na ordem masculina de ideologia patriarcal, um crime quando praticado pela mulher. Assim, "o adultério feminino tornou-se obsessão de inúmeros críticos machos” (BESSE, 1999, p. 49):

\begin{abstract}
Entre os crimes passionais, o mais debatido era o cometido como reação ao adultério. Apoiado na tradição machista e patriarcal, o crime seria predominantemente masculino. Nessa tradição, a honra manchada lavava-se com sangue. Já o adultério masculino normalmente provocava acomodação por parte das mulheres, em especial nas camadas médias e burguesas, temerosas de uma ruptura que as obrigasse a mudar de vida. (DEL PRIORE, 2015, p. 265)
\end{abstract}

Dessa forma, mesmo com a mudança da família patriarcal para a família nuclear no Brasil, a ideologia será responsável pela manutenção na dupla moral sexual, que também será responsável pelo controle do corpo e da vida da mulher:

Apesar de transformada, porém, esta nova família conjugal preserva um traço típico da família anterior: o predomínio da dupla moral sexual, que reprime a sexualidade feminina, mantendo o tabu da virgindade e a intolerância para com o adultério feminino, e reforça no homem a prática da sexualidade trazendo em seu bojo a tolerância da sociedade para com o adultério masculino e para com a prostituição, seu complemento natural e necessário. (BRUSCHINI, 1990, p. 64)

Não será, no entanto, só a partir de sua criminalização - o crime da honra a que os homens apelaram em tantos processos judiciais do período em suas práticas de violência - que o adultério feminino será reprimido. Também será na cisão entre 
a mulher assexuada e a mulher sexuada, correspondendo esta ao papel da prostituta e aquela ao de esposa e mãe. Assim, o desejo feminino será contido pelo controle do corpo através de uma ideologia que transforma as mulheres em bedéis de si mesmas, o que obviamente é corroborado pela moral católica em conformação com ideologia patriarcal, que será notável no Brasil e também apresentará ecos em Portugal porque coincidente com o o discurso burguês de maneira geral, como é possível depreender da análise de Margareth Rago:

Identificada à religiosa ou mesmo considerada como santa, à imagem de Maria, a mãe será totalmente dessexualizada e purificada, ainda mais que, ao contrário, a mulher sensual, pecadora, principalmente a prostituta, será associada à figura do mal, do pecado e de Eva, razão de perdição do homem. Assim, serão contrapostas no discurso burguês duas figuras femininas polarizadas, mas complementares: a santa assexuada mas mãe, que deu origem ao homem salvador da humanidade, que padece no paraíso do lar e esquece-se abnegadamente dos prazeres da vida mundana, e a pecadora diabólica, que atrai para as seduções infernais do submundo os jovens e maridos insatisfeitos. A primeira, toda alma e sacrifício - símbolo do bem; a segunda, exclusivamente carnal e egoísta - encarnação do mal. Ambas, no entanto, submissas, dependentes, porcelanas do homem, incapazes de um pensamento racional e, consequentemente, de dirigirem suas próprias vidas. (...) Vale atentar para a maneira pela qual o discurso burguês ao estabelecer uma rígida linha de demarcação entre os sexos, dessexualiza a mulher. Assim, na representação santificada da mãe-esposa-dona-de-casa, ordeira e higiênica, o aspecto sexual só aparece se associado à ideia de procriação. (RAGO, 1985, p. 8283)

Além desses fatores, caberá a um terceiro a manutenção da ordem que assegurará a constrição das mulheres em seus papéis de esposas e mães: a dependência econômica, principalmente a que acontece nas camadas mais ricas da sociedade. Se por um lado as novas diretrizes do mundo moderno abriam espaço para uma mulher consumidora, também responsável pela circulação de mercadoria, 
o que era estimulado através dos meios de comunicação ${ }^{31}$, como as revistas femininas, por outro o trabalho feminino era inferiorizado não só com relação à remuneração desvalorizada às quais as mulheres estavam sujeitas, como também pela reverência da ideia de sua função desmoralizadora:

Com a crescente incorporação das mulheres ao mercado de trabalho e à esfera pública, lembra a historiadora Margareth Rago, a questão do trabalho feminino era motivo de discussão com outros temas que envolviam as mulheres: virgindade, casamento e prostituição. Enquanto o mundo do trabalho cabia como uma luva na metáfora do "cabaré", o lar era valorizado como espaço sagrado da "santa e rainha do lar", do "reizinho de família". Com o vertiginoso crescimento urbano das primeiras décadas do século, o mundo do trabalho passou a ser visto como algo profundamente ameaçador para as mulheres e não faltavam críticos dessa situação. (DEL PRIORE, 2015, p. 267)

Baseada nesses quatro alicerces que fornecerão fundamentação à manutenção do controle sobre o corpo e a vida da mulher, ainda que sob novas organizações sociais, a insistência do casamento como única via de realização feminina, a oposição à separação, a criminalização do adultério feminino - através de mecanismos legais e ideológicos, também sob moral religiosa -, e a dependência econômica, a ideologia patriarcal se mantém fortalecida em pleno século XX no Brasil. No entanto, para isso haverá resposta de uma resistência organizada, a que se nomeará de primeira onda feminista.

\footnotetext{
${ }^{31}$ As revistas femininas do período apresentavam, ao mesmo tempo, um fortalecimento do papel necessário da mulher na ordem familiar e uma indução a essa ao mercado consumidor. E não era raro, por exemplo, que uma página que alicerçava as necessidades de uma boa esposa, desprovida de vaidade, fosse seguida por uma propaganda de qualquer produto de beleza. Assim, em sua abordagem sobre a Revista Feminina, esclarece-nos Besse: "Ao mesmo tempo, os anúncios - que assumiam uma posição cada vez mais proeminente, à medida que a revista expandia - não só exaltavam as maravilhas dos produtos modernos como também exploravam a sexualidade feminina para vende-los" (1999, p. 28).
} 


\section{Um feminismo possível?}

Dentro dessa configuração bastante complexa das primeiras décadas do século XX no Brasil, surgem as primeiras manifestações feministas com ideias sufragistas mas que, para além disso, versavam sobre a ampliação do acesso feminino à educação e a certa autonomia. Embora esse feminismo tenha sido reconhecido como feminismo comportado, por teóricas como Céli Pinto (2003), é notável como tal feminismo correspondia a algumas vertentes de reivindicações que ocorriam no mundo inteiro em virtude da maior movimentação das mulheres em busca de seus direitos enquanto cidadãs. Tais reivindicações advinham de movimentações organizadas ou através de vozes mais isoladas, de qualquer maneira havia o vínculo entre as atuações que demonstrava que elas não eram exceção, senão resultado de uma insatisfação coletiva:

O processo de urbanização, acompanhado do surgimento de camadas médias e operárias, criou um caldo de cultura para o aparecimento de novas formas de organização da sociedade. $O$ movimento das mulheres parece ser um exemplo das formas que essa organização podia tomar e aponta para um aspecto importante: não se tratava de um grupo que lutava diante das instâncias do Estado, ou que simplesmente buscava deputados para propor projetos de seu interesse, mas de uma estratégia mais complexa. $O$ uso constante de jornais, a presença em eventos públicos e até a realização de uma passeata mostram que essas mulheres não eram apenas exceções excêntricas de uma época de recato, mas pessoas que pretenderam ampliar sua base de apoio buscando formar uma opinião pública a seu favor. (PINTO, 2003, p. 18)

O caldo cultural que possibilitou a atuação dessas mulheres que viriam a público requerer direito das mulheres apontava para o fato comum de que tais mulheres eram oriundas de famílias da elite brasileira e que, por isso, tiveram acesso aos instrumentos educacionais necessários para fomentar oposição à opressão das mulheres. Ainda que fizessem parte de família com os mesmos 
princípios ideológicos patriarcais, o acesso à educação que puderam obter fissurava o sistema consolidando as possibilidades de questionamento.

Surge então em 1910 o Partido Republicado Feminino que vai estabelecer a primeira ruptura com o processo vigente. Fundado por Leonlinda Daltro ${ }^{32}$ e Gilka Machado $^{33}$, o partido consegue colocar na imprensa carioca a questão do voto depois de ter organizado uma passeata com cerca de 90 mulheres no Rio de Janeiro, em 1919, numa época em que a rua tinha acesso restringido às mulheres ${ }^{34}$. Dessa maneira demandando reivindicações, o Partido batia de frente com a Constituição brasileira de 1891 em que sequer mulher era citada, segundo Céli Pinto:

\begin{abstract}
A não-inclusão da mulher no texto constitucional não foi um mero esquecimento. A mulher não foi citada porque simplesmente não existia na cabeça dos constituintes como indivíduo dotado de direitos. A Constituição estabeleceu que eram cidadãos brasileiros aqueles nascidos no Brasil, e eram eleitores os cidadãos brasileiros maiores de 21 anos. Conforme o senso comum da época, quando o legislador usou o substantivo "cidadão" no masculino, não estava se referindo ao termo universal que abrange homens e mulheres, mas exclusivamente aos homens. (PINTO, 2003, p. 16).
\end{abstract}

Além disso, o Partido abriu espaço para que outras frentes insurgissem, como foi o caso da Federação Brasileira para o Progresso Feminino que, nascida em 1922 através de iniciativa de Bertha Lutz ${ }^{35}$, tornou-se "a mais importante e conhecida organização em defesa dos direitos da mulher do período" (PINTO, 2003, p. 23). A federação era composta majoritariamente por filhas de intelectuais, de

\footnotetext{
32 "Leolinda de Figueiredo Daltro (1859-1935) foi uma mulher muito diferente das de seu tempo. Criou cinco filhas separada do marido e, a partir de 1895, percorreu sozinha o interior do Brasil, passando por Minas Gerais e Goiás, chegando à fronteira do Maranhão, em uma cruzada em defesa dos índios, contra o extermínio e o autoritarismo da catequese. Em 1909, requereu o alistamento eleitoral e, não conseguindo, fundou o Partido Republicano Feminino" (PINTO, 2003, p. 18-19).

${ }^{33}$ Gilka da Costa de Melo Machado (1893-1980) era filha de artistas, seu pai era poeta e sua mãe atriz de teatro e radioteatro. Gilka foi uma poetisa que escandalizou seus contemporâneos com sua poesia erótica.

${ }^{34}$ Cf. PINTO, 2003, p. 19.

${ }^{35}$ Bertha Maria Julia Lutz (1894-1976) era filha do cientista Adolfo Lutz com a enfermeira inglesa Amy Fowler e, devido à avantajada situação econômica de seus pais, tem acesso à educação e estuda em Paris, onde entra em contato com as sufragistas francesas.
} 
elite, que atuavam profissionalmente e que apresentavam, devido a essas condicionantes, inserção social e cultural que permitiam pressões políticas acerca dos direitos das mulheres.

Tais movimentos buscarão a reorientação da Constituinte através de mulheres que faziam parte das elites econômicas brasileiras, que possibilitaram o acesso às filhas ao "mundo culto da leitura e da valorização da educação" (PINTO, 2003, P. 17). O objetivo primeiro, a partir dos primeiros anos do século $X X$, foi então seguindo os princípios do movimento mundial do sufrágio, cuja vitória aconteceria por aqui em 1932. Outra questão, no entanto, fazia-se valer: a dependência econômica das mulheres, principalmente das elites brasileiras (uma vez que as trabalhadoras representam um quadro à parte) que não tinham qualquer autonomia financeira e, assim sendo, tinham o casamento como via de subsistência. $O$ casamento então não era só uma demanda social, como já apontamos anteriormente, mas também uma demanda econômica, o que dificultava, sobremaneira, a resistência ao cumprimento do papel exclusivo de esposa e mãe pela mulher, em obediência à ideologia patriarcal. A sobrevivência dessas mulheres dependia necessariamente do marido ou ainda de outro homem que, na ausência do marido, por elas se responsabilizassem, como era o caso das mulheres que ficavam solteiras e cujas vidas, vias de regras, ficavam atreladas a de outros familiares, assim como a tia de Maria Luísa.

Portanto, a este feminismo um outro ponto fundamental se alocaria exatamente na contradição a partir do final dos anos 1920: a questão econômica ou a necessidade do acesso da mulher ao mercado de trabalho. Evidenciado está, a partir disso, a dificuldade de encaminhamento desse movimento que passa a ter que negociar com as entranhas de um sistema político masculino. Para tanto, só era possível essa negociação através de mulheres que tinham trânsito livre, e que assim eram "altamente elitistas" e, por isso, defendiam direitos que não necessariamente atenderiam demandas específicas das mulheres das classes trabalhadoras e buscavam assegurar que suas negociações não resultassem em retrocesso de qualquer direito de que eram, elas próprias, beneficiárias.

Esse movimento, no entanto, toma proporções por todo o país, em outros estados afora do eixo Rio-São Paulo em que começaram a se consolidar. É significativa a atuação de mulheres de Minas Gerais, Rio Grande do Norte, Paraíba, principalmente a partir do final da década de 1920 e início dos anos 1930, 
demonstrando que "não se tratava unicamente de mulheres com ideias estranhas para a sua época ou apenas excepcionais, pela cultura ou pela coragem", mas sim condizentes com o "espírito da época" (PINTO, 2003, p. 28). No mesmo período, sucede a Revolução que incidiria consideravelmente na política aplicada no país, que finda a República Velha e permite a ascensão de Getúlio Vargas ao poder. Como resultado, o movimento conseguiu estipular o direito ao voto da mulher em 1932 através do novo Código Eleitoral que abria o espaço político para mulheres votarem e serem votadas, mas a movimentação sofreria opressão a partir de 1937, quando o golpe varguista tira espaço de atuação da FBPF, através de um projeto político conservador em termos de direito das mulheres, buscando salvaguardar a família aos seus moldes.

Céli Pinto (2003) ainda faz referências a outras duas atuações que seriam cruciais a essa movimentação feminista dos anos 1930. A primeira era o jornalismo, através do qual essas mulheres conseguiam difundir suas ideias. É importante notar que, neste período, as revistas femininas traziam para a esfera da informação, como já mencionamos, os anúncios que transformavam cada vez mais as mulheres em consumidoras, assim como buscavam assegurar o papel da mulher como esposa e mãe, com dicas de comportamento, ao mesmo tempo em que começavam a difundir a ideia da profissionalização das mulheres, numa transição que foi dos ditames da moda, quase exclusividade no século XIX, para uma acepção da mulher moderna com certa autonomia, entre os anos 1920 e 1930. Muitas revistas surgiam a partir de iniciativas de mulheres com algum poder aquisitivo e duravam, a algumas exceções, como a Revista Feminina, poucas edições.

A segunda atuação foi a do anarquismo, que ganha força no Brasil a partir do início do século XX e que, embora mantivesse uma distância do feminismo por seu papel ambíguo com relação à questão de gênero, já que por um lado defendia a participação na esfera pública das mulheres - agora companheiras, mas por outro não aceitava completamente a dissociação da opressão de gênero à opressão de classe, abria espaço para que as mulheres se manifestassem e sinalizava também para o que o anarquismo propunha de diferente das sufragistas:

Mas se, por um lado, é verdadeira a distância entre estes movimentos libertários e o feminismo, por outro as próprias ideologias que o professavam diminuíam o espaço do preconceito 
contra as mulheres, permitindo que muitas delas se expressassem. Aí reside uma espécie de paradoxo: é nesses espaços revolucionários, não-feministas em princípio, que se encontravam, nas primeiras décadas do século $X X$, as manifestações mais radicalmente feministas, no sentido de uma clara identificação da condição explorada da mulher como decorrência das relações de gênero. Diferentemente das sufragistas, essas mulheres apontavam sem meias palavras a opressão masculina. (PINTO, 2003, p. 34)

Essas mulheres defenderiam o direito das mulheres trabalhadoras, apontando a responsabilidade do sistema capitalista por sua opressão dentro das fábricas e dentro do lar. É o caso da anarquista Maria Moura ${ }^{36}$, por exemplo, que apresenta o homem como opressor, enquanto patrão das mulheres. Maria Lacerda Moura tecia críticas ao feminismo representado por Bertha Lutz, que denunciava por só atentar para as mulheres da elite brasileira. As anarquistas seriam responsáveis por duas importantes manifestações durante no início do século XX: o manifesto de 1906, no jornal Terra Livre, em que trabalhadoras do setor têxtil chamam as mulheres para aderirem à greve indicando reivindicações específicas como a necessidade de conciliar trabalho e leitura; e o manifesto das mulheres costureiras, de 1920, em que se aponta a necessidade de se olhar para a desigualdade entre os gêneros nas fábricas. Apesar disso, é importante frisar que a ideologia patriarcal também fará salvaguarda dos estatutos do poder masculino dentro desses movimentos que tentavam transformar as operárias em vítimas passivas, conforme nos alerta Margareth Rago em sua análise sobre o trabalho feminino e sexualidade nas primeiras décadas do século XX:

Isso significa que lidamos muito mais com a construção masculina da identidade das mulheres trabalhadoras do que com a percepção de sua condição social, sexual e individual. Não é à toa que, até recentemente, falar das trabalhadoras urbanas no Brasil significava retratar um mundo de opressão e exploração demasiada, em que

\footnotetext{
${ }^{36}$ Maria Lacerda de Moura (1887-1945) foi intelectual anarquista e feminista, professora. "Nascida em Minas Gerais, em 1887, de uma família modesta, ativista anarquista, radical, foi professora e autora de muitos livros nos quais expôs suas ideias feministas, que iam desde questões relacionadas com a participação política até a defesa aberta do amor livre e da educação sexual" (PINTO, 2003, p. $36)$.
} 
elas apareciam como figuras vitimizadas e sem nenhuma possibilidade de resistência. Sem rosto, sem corpo, a operária foi transformada numa figura passiva, sem expressão política nem contorno social. (RAGO, 2017, p. 579)

É-nos caro apresentar isso porque corresponde ao papel que Antônio procura imputar à Maria Aparecida em Amanhecer, na dinâmica estabelecida pela autora implícita, conforme veremos a seguir. Outra questão proeminente relacionada à militância anarquista, que era tanto defendida por homens quanto por mulheres, como Maria Lacerda de Moura, é a que corresponde à ideia de amor livre, com sua respectiva crítica às relações monogâmicas indissolúveis. "O "amor livre", por sua vez, daria lugar à plena manifestação das emoções entre homens e mulheres" (...) enquanto a "livre união" significaria a possibilidade de definir livremente o tipo de relação amorosa mais adequada para cada qual" (DEL PRIORE, 2015, p. 259). Um exemplo disso foi a atuação de Ercília Nogueira $\mathrm{Cobra}^{37}$, que assumia suas acepções de amor livre através da defesa de uma igualdade entre homens e mulheres para que estas pudessem exercer uma profissão e ter independência econômica a fim de terem autonomia para deliberar sobre suas vidas e, consequentemente, sobre suas relações afetivas.

Com este panorama sobre as condições de vida da mulher na década de 1930 e ainda sobre as movimentações feministas destacadas no mesmo período, tornase possível traçar uma observação mais acurada sobre as escolhas da autora implícita nas estruturas dos romances de Lúcia Miguel Pereira, Maria Luísa e Amanhecer. A fim de dar continuidade à análise de cunho comparativo, no entanto, faz-se necessário que observemos o que acontecia em Portugal, no mesmo período.

\footnotetext{
${ }^{37}$ Ercília Nogueira Cobra (1891- ?). Ercília será conhecida pela defesa à independência econômica da mulher e a sua liberdade sexual. Durante os anos 1920, escreveu dois livros Virgindade AntiHygiência e Virgindade Inútil. Desempenhará papel fundamental da defesa desses direitos, conforme nos aponta sua biógrafa Maria Lúcia Mott (1986, p. 91): "Partidária do amor livre, defende a liberdade sexual com energia surpreendente. Denuncia a dupla moral que estigmatiza a mulher - e não o homem - que tem relação sexual fora do casamento". Ercília foi presa e torturada pelo Estado Novo por seus ideais revolucionários, e sofreu diversos ataques da sociedade do período, o que a obrigou a assumir nova identidade nos anos 1940.
} 


\section{Enquanto isso, em Portugal}

Em Portugal, durante os primeiros anos do século XX, havia uma configuração bastante peculiar com relação à participação feminina na vida pública. Camponesas vindas à Lisboa desde o final do século anterior no processo de industrialização que se consolidava, ainda que em baixa marcha quando comparado ao restante da Europa, fizeram aumentar a força reivindicativa das mulheres. Todavia, é imprescindível notar que os ecos do forte movimento sufragista europeu do período chegaram a Portugal num contexto do movimento republicano que, por sua vez, contrapunha o estado de coisas vigentes a partir da reivindicação de novas demandas sociais. Sob essa configuração, ganha força o movimento feminista português que busca maior liberdade e autonomia para as mulheres. Não obstante, as mulheres sofrerão uma traição dos companheiros do movimento republicano que Ihes vetam o direito ao voto.

Contraditoriamente, tal quadro será revertido apenas na constituição de 1934, em plena ditadura salazarista, quando o direito de voto será concedido às mulheres portuguesas, muito embora de maneira restrita uma vez que se exigia diploma universitário ou especial secundário num país em que os índices de analfabetismo feminino eram, a essa época, bastante elevados. É também em 1934 que surgem as primeiras candidatas a um cargo político no país. É importante ressaltar ainda que, muito embora esse direito tenha sido conquistado neste período, Salazar o declarou pelo exato mesmo motivo, que para si teria consequência inversa, que o defendido pelos republicanos: acreditava-se que as mulheres teriam um voto conservador $^{38}$, dessa forma, "essa situação prendeu-se com a forma como a ditadura salazarista encarou na época o voto feminino". Havia a noção - e a esperança -, no seio do regime, de que "se as mulheres votassem, Salazar e o seu governo ganhariam sempre as eleições" (PIMENTEL, 2001, p. 30).

\footnotetext{
${ }^{38}$ Também na Espanha se pensava essa conotação conservadora no voto feminino, algo que não se confirmou porque a Frente Popular saiu vitoriosa, mas que foi impresso em Portugal através de um articulista republicano. Cf. PIMENTEL, 2002, p. 32: "Ecoando opiniões então existentes, tanto em Espanha, onde o voto feminino já era um facto, como em França, onde os "velhos do Senado" ainda achavam cedo para dar o voto às mulheres, o articulista do vespertino português de oposição (a Salazar) perguntava se os senadores franceses não teriam razão ao recusar o sufrágio às mulheres, "ainda agarradas a velhas tradições". O certo é que nas eleições realizadas em 16 de fevereiro saiu vitoriosa a Frente Popular em Espanha.
} 
Como podemos observar, a conquista do voto feminino ocorreu em Portugal em condições parecidas as do Brasil, com apenas dois anos de diferença, uma vez que por aqui isso também tinha afluído durante os primeiros anos de governo varguista e também de maneira bastante restritiva. Não obstante, não é apenas aí que as histórias coincidem no que condiz aos direitos femininos, uma vez que em Portugal também predominava uma ideologia patriarcal, que será fortalecida sobremaneira por Antônio Salazar. Salazar ao mesmo tempo em que se apoiava nas mulheres a fim de construir com essas uma educação de apoio ao regime aliás, em termos de atuação pública, era a educação o lugar reservado às mulheres, o que correspondia exatamente ao seu lugar de educadoras no lar -, defendia que essas deveriam obedecer aos maridos, voltar-se para as atividades domésticas e abdicar de seus desejos e prazeres, o que foi manifestado em formas de decreto e em falas do ditador, como a conhecida entrevista que concedeu a Antônio Ferro.

A ditadura de Antônio Salazar irá impor sérias condições sobre a vida das mulheres, mesmo que sobre aquelas da elite cujas ideias tinham encontrado eco no movimento republicano, uma vez que seu lema versava desde o início dos anos 1930 na máxima Deus, Pátria, Família, tudo sedimentado através do autoritarismo, o que coincide, como sabemos, com os moldes do totalitarismo mundial, que também apresentou seus tentáculos no Brasil com Getúlio Vargas. Acerca dessa máxima, os indivíduos perdiam autonomia, de maneira geral. Em Portugal, Salazar abstrai o conceito de cidadão, transferindo para a família, a seguir às corporações, as existências individuais. Isso reflete significativamente sobre a vida das mulheres:

Em 1936, num texto político (...) Salazar expõe claramente o lugar que dá às mulheres na cidade ou na "república". Considerando o conceito de "cidadão" como se fosse uma abstracção, um conceito errôneo ou insuficiente, propõe a substituição pela de "grupos naturais necessários à vida individual e que constituem a sociedade política". Na base a família, depois as corporações. (...) Vejamos as consequências desta posição doutrinária para as mulheres. Se o cidadão/cidadã não existe, é apenas como elemento do grupo social família, tal como Salazar a entende, que a mulher existe socialmente. (BELO et al., 1987, p. 264) 
No entanto, nota-se que a destituição da mulher como cidadã, fato que mal se havia constituído efetivamente, uma vez que o voto feminino só foi garantido (parcialmente) em 1934, ocorreu pouquíssimo tempo depois do direto ao voto, o que irrompe na consequência dramática de retroceder com todas as discussões que estavam sendo encaminhadas até ali por um grupo de mulheres que, além da preocupação com o voto feminino, também manifestavam atenção com relação à dependência econômica da mulher e, além disso, embora suas posições com relação ao casamento fossem a primeira vista conservadoras, haviam conquistado o direito ao divórcio em 1910, fato excepcional para o período, resultante das vertentes progressistas do movimento republicano. Portanto, se nas duas primeiras décadas do século XX pode-se observar uma mudança de paradigma, ainda que conservadora, com as condições de vida da mulher portuguesa, correspondente às mudanças estruturais que ocorriam no país na virada do século, a partir da ascensão de Salazar, cujo marco inicial é 1926, as conjunturas sociais mudam de rumo. Nos anos 1930, tendo a economia portuguesa sido afetada pela crise mundial de 1929, os resultados dessa operação conservadora para as mulheres tornam-se ainda mais dramáticos, uma vez que haverá a tentativa de retirá-las do mercado de trabalho para que o mesmo espaço fosse devolvido aos homens, responsáveis pela economia familiar dentro do projeto salazarista.

Sobrevém então que a mulher portuguesa será alvo do programa da ditadura salazarista a partir de seu papel, como dissemos, dentro da família, e, portanto, voltado ao lar, em obediência ao marido, conforme denota Belo ao resgatar uma fala de Salazar:

As mulheres não compreendem que não se atinge a felicidade pelo prazer, mas sim pela renúncia. As grandes nações deveriam dar o exemplo, conservando as mulheres no lar. Mas as grandes nações parecem ignorar que a constituição sólida da família não pode existir se a esposa viver fora de sua casa. (...) O Secretariado Nacional de Propaganda (SNP) publica assim um livro bem esclarecedor, intitulado Economia Doméstica. Nele ensina-se as mulheres a viver uma vida de "penúria agradável", uma vida conjugal económica, submetida, resignada. (BELO et al., 1987, p. 266) 
Esse quadro será fortalecido a partir da Constituição de 1933, que cedia o direito ao voto às mulheres, uma vez que, como já mencionado, acreditava-se que seria um voto conservador, concomitantemente com a defesa do papel social da mulher claramente exposto como sendo de esposa (obediente e submissa) e mãe, uma vez que, segundo Pimentel (2001, p. 27), "defendia-se a volta da mulher ao lar, com a valorização do "belo" papel de mãe e esposa - no entanto, configurando-se dentro da hierarquia dos papeis sociais, estando a mulher subjugada primeiro ao pai, depois ao marido".

Diante do projeto político que tinha como objetivo a "volta das mulheres ao lar", há uma conotação acentuada no papel da mulher na economia familiar:

Esta tinha uma economia própria ou, melhor, "duas economias": uma representada pelo salário do homem, e outra, pela "produção" no seio da família, que cabia, segundo a divisão sexual do trabalho salazarista, à mulher. $O$ ditador reconhecia, no discurso, a importância moral, social e econômica das tarefas femininas no lar, uma forma hábil de tentar ganhar 0 apoio das mulheres que 0 liberalismo tinha alienado, precisamente porque mantivera invisível o trabalho doméstico e as atirara para o mercado de trabalho. (PIMENTEL, 2001, p. 28)

No entanto, Salazar instigava as mulheres ao apoio a seu governo, apostando numa dinâmica em que caberia a elas também a edificação do aparelho ideológico do Estado Novo, e para tanto, fortaleceu as organizações femininas, que já vinham demandando atenção em Portugal desde o início do século e que, por conseguinte, exigiam uma força persuasiva que resultasse em apoio à Ditadura, enquanto esta ainda tentava se fincar embasada em apoio popular ${ }^{39}$ :

É nas organizações femininas do regime que vamos encontrar as características desta doutrina sobre as mulheres: por um lado, a mulher fada do lar, por outro a mulher colaboradora activa e com frequência muito entusiasta na edificação do aparelho ideológico do Estado Novo. A ditadura e o antiliberalismo expressos integram esse

\footnotetext{
${ }^{39}$ Este cenário sofrerá modificações com o fim da Segunda Guerra, quando os regimes totalitários perdem o poder. Refuta-se então o apoio popular em prol de uma forte repressão em Portugal.
} 
aparelho. Não é, pois, de estranhar que Salazar reserve para o Estado o papel de formação ideológica. No campo feminino, duas organizações vão nascer: a Obra das Mães para a Educação Nacional (OMEN) e a Mocidade Portuguesa Feminina (MPF). (BELO et. al., 1987, p. 268)

Se são diversas as estratégias adotadas para este fim, que contam também com iniciativas legais sustentadas por decretos estatais, é na base ideológica que incide sua força. Para tanto, a educação feminina, que neste momento já havia crescido consideravelmente em Portugal, será alvo da Ditadura, buscando, todavia, sustentar-se também nas mulheres que apoiavam o Estado Novo nas organizações femininas. Há, então, um cenário contraditório, porque as mulheres que já integravam o sistema educacional, que faziam parte de uma elite e que fortaleciam os movimentos de reivindicação de mulheres, não seriam facilmente catequizáveis pelo Estado:

\begin{abstract}
Assim, numa sociedade onde "algumas camadas dirigentes advogam firmemente uma estratégia de analfabetismo total" - que é a outra face da bandeira de um regime que defendia a citada nostalgia do campo e ingenuidade rural -, os frutos foram contraditórios. A grande maioria das raparigas não integram 0 sistema escolar, e as que o integram formaram necessariamente uma elite, dificilmente catequizável, e por isso nem sempre dócil, obediente e acrítica. (BELO et. al, 1987, p. 269)
\end{abstract}

Portanto, será em meio a esse panorama político complexo que se consolidarão as reivindicações feministas do período. Uma das vias de sua consolidação que corresponde a essa complexidade é a educação feminina. 


\section{A educação feminina}

Em Portugal, no final do século XIX, os índices de analfabetismo eram altos, principalmente com relação à população feminina. Tal quadro sofrerá significativa modificação durante a primeira metade do século posterior:

Em 1878, 89,3\% da população feminina maior de sete anos não sabia ler nem escrever, ou seja, nove em cada dez portuguesas eram analfabetas. Em 1930, o panorama não era mais animador: a taxa de analfabetismo feminino baixara apenas para 74,3\%. Apesar do relativo progresso, fruto sobretudo do esforço da I República para alargar o sistema de ensino a todo o país, as mulheres mantinhamse à margem de instrução pública e rede escolar. (VAQUINHAS, 2005, p. 74)

Dessa maneira, o acesso das mulheres à instrução foi resultado de reivindicações e visavam, de alguma forma, a partir do final do século, "forjar uma cidadania feminina" (VAQUINHAS, 2005, p. 75), facilitando o acesso de mulheres também ao espaço público. No entanto, isso só foi possível através de um componente que também esteve presente no Brasil, acreditava-se que a educação feminina era importante para que a mulher desempenhasse melhor o seu papel de esposa e mãe:

Considerava-se axiomático que a função social da mulher era a de ser esposa e mãe e que para desempenhar esse papel necessitava, sobretudo, de valores morais e sentimentais. Anjo do lar, a sua finalidade era a de criar um ambiente de amor e de paz para a sua família, um refúgio onde o seu marido se podia abrigar do mundo atribulado da política e dos negócios. Nesta linha de domesticidade burguesa, o conteúdo intelectual da educação da mulher era escasso, considerando-se que intelectualidade não rimava com feminilidade. A imprensa de caráter conservador e clerical defendia a ideia de que uma instrução de alto nível não era possível nem desejável para as raparigas, argumentando com a sua pretensa 
inferioridade intelectual e com o facto de, assim, se eximirem aos deveres familiares. (VAQUINHAS, 2005, p. 75)

A partir de meados do século XIX, portanto, aumentam consideravelmente 0 número de escolas para educação feminina, muito embora todas ligadas à igreja católica, uma vez que o objetivo não era a emancipação feminina e sim sua melhor formação para assumpção do seu papel de mãe e esposa, dessa forma, a educação feminina conforma-se como moral e religiosa. No entanto, a partir do final do século $\mathrm{XIX}$, as feministas ligadas às causas republicanas tornarão pública a necessidade de instrução feminina a fim de que as mulheres pudessem exercer os seus papéis de cidadãs, mudando assim a configuração inicial dessa reivindicação. O número de escolas secundárias aumenta assim como o acesso feminino à educação secundária também, mas se diferenciava a educação da mulher burguesa e a da classe popular, uma vez que das primeiras intencionava-se uma formação cultural adequada ao meio.

Para as primeiras pretendia-se uma formação cultural adequada ao meio da origem e suficiente abrangente que lhes permitisse serem interlocutoras do seu marido, bem como elemento de relacionamento social entre famílias. Admitia-se que a instrução fosse ela do ensino primário, embora sem alcançar um nível equivalente ao masculino, uma vez que a formação feminina continuava a ser determinada pelas funções de esposa e de mãe. (VAQUINHAS, 2005, p. 78)

Diferenciava-se também a questão moral nas duas educações, já que se procurava manter a ordem social também no movimento de mulheres trabalhadoras, portanto para estas a moral era ainda mais preponderante na educação. É importante notar, no entanto, que o crescimento das mulheres em escolas efetivamente ocorre das primeiras décadas do século $X X^{40}$, período que antecede a ascensão de Salazar ao poder quando novas trajetórias para a educação feminina

\footnotetext{
${ }^{40} \mathrm{Em} \mathrm{1908,} \mathrm{apenas} \mathrm{9,5 \%} \mathrm{da} \mathrm{população} \mathrm{liceal} \mathrm{global} \mathrm{era} \mathrm{constituída} \mathrm{por} \mathrm{meninas,} \mathrm{enquanto} \mathrm{em} 1920$ chega-se a $24,2 \%$ de todos os alunos matriculados. Cf. VAQUINHAS, 2005, p. 79.
} 
serão consolidas no sentido de, ainda mais uma vez, assegurar o papel de esposa e mãe.

Assim, se no início do século $X X$, os liceus femininos tinham um caráter híbrido, em que se mesclavam "disciplinas científicas com actividades domésticas", segundo Vaquinhas (2005, p. 80), isso será consolidado através da política salazarista para mulheres que apresentará características que vão se materializando ao longo dos anos 1930, em que se pretendia formar mulheres voltadas para os afazeres domésticos formadas numa moralidade cristã que ratificariam a ideologia salazarista, inclusive no que tange o controle da mulher. Sendo assim, durante os primeiros anos de Salazar, o que se pode observar:

É o período de instalação e de crescimento de uma ditadura nacionalista confessa que procura e obtém o apoio e a participação política de uma elite de mulheres enquanto tais. O feminino e as suas características são exaltadas ao ponto de serem o modelo de governo de Estado. (BELO et al.; 1987, p. 275)

Ainda que, contraditoriamente, as mulheres fossem anuladas nessa política:

Para poder identificar-se com as mulheres, Salazar precisou de as anular como tal. Foram as mulheres solteiras, ou de marido ausente, as "senhoras" ou as "mulherzinhas", as mulheres, sem outro desejo do que governar a casa ou colaborar com o regime, aquelas a que 0 "Chefe" se identificou e que a ideologia do regime exaltou. (BELO et al.; 1987, p. 276)

Para efetivar os encaminhamentos da ratificação ideológica através da educação, com viés patriarcal, mais uma vez no que tange o poder dos homens sobre as mulheres, foi necessário criar organizações que assumiriam tal encargo. Formou-se, então, duas principais com preocupação exclusiva com as mulheres, a Obra das Mães pela Educação Nacional (OMEN), em 1936, e no ano seguinte a Mocidade Portuguesa Feminina (MPF):

Antes, porém, que a Escola, "oficina dos pais amanhã", fosse reformada, tornara-se necessário criar uma organização da 
juventude que transmitisse "a consciência e unidade nacionais, hábitos de coesão e patriotismo militante, disciplina militar, activa confiança nos destinos de Portugal" e uma organização de mulheres, para "corrigir e suprir as deficiências" no país "de hoje". Por isso, foi criada, ainda em 1936, a Obra das Mães pela Educação Nacional (OMEN), com a missão de "estimular a acção educativa da Família" e "preparar melhor as gerações femininas para os seus futuros deveres maternais, domésticos e sociais". Era à OMEN que competia, por isso, organizar a secção feminina da Mocidade Portuguesa, que, no entanto, apenas foi regulamentada e 8 de dezembro de 1937, com o nome de Mocidade Portuguesa Feminina (MPF). (MADEIRA, 2007, p. 293)

As organizações femininas seriam responsáveis pelas atividades de cunho moral e nacionalista que pauta a educação feminina, para além disso, estariam estritamente ligadas à formação cristã, uma vez que se legitimava o nacionalismo português, segundo Madeira (2007, p. 295) também no catolicismo. Desta maneira, a Igreja Católica continuará tendo participação fundamental na instrução feminina, apregoando a sua moral religiosa, que arregimenta o cerceamento das mulheres sobre o próprio corpo, além de obviamente promulgar o casamento como única possibilidade na vida das mulheres e à obediência ao marido como máxima ordem moral.

A partir de 1937, com a MPF, formou-se a ideologia que deveria regular a vida das mulheres, tecendo a noção de "nova mulher", que se evidenciava em conformação com a noção do "novo homem" que o regime salazarista tentava determinar:

Sob a cúpula da religião católica que tudo enformava, pretendia-se formar, por um lado, uma elite feminina com vocação de educar e servir socialmente, e criar, na "massa", o conceito da missão da mulher no lar. A "nova" mulher seria cristã, "moralmente sã", "portuguesa" e ao serviço do Estado Novo no espaço próprio que lhe era reservado. Por isso, a filiada foi desde logo também educada no culto dos chefes do regime e das dirigentes das organizações femininas, mas... non troppo. (MADEIRA, 2007, p. 295) 
Como havia a intenção da retirada da mulher do mercado de trabalho, uma vez que o salazarismo contava com isso para tentar resolver o problema de desemprego que assolava o país, a instrução feminina nas bases das organizações não visava uma formação profissional ${ }^{41}$, senão a consolidação dos valores morais que manteriam como função social da mulher esposa, mãe e dona-de-casa:

No fundo, estes argumentos justificavam, como se verá no próximo capítulo, o propósito de eliminar a concorrência feminina de um mercado de trabalho onde havia desemprego e no qual algumas empresas competiam desregrada e deslealmente com outras, à custa da mão-de-obra feminina e infantil, mais barata. Para travar esse processo, Salazar aparentava corresponder, no discurso, às críticas contra a destruição da família e o trabalho fabril, formuladas pelas organizações femininas, nomeadamente as católicas, que reivindicavam o retorno da mulher ao lar e apelavam ao reconhecimento da "função social" da maternidade e do trabalho doméstico. (PIMENTEL, 2001, p. 29)

No entanto, conforme já procuramos apontar, como se diferenciava a educação de mulheres pobres e de mulheres de elite desde o final do século XIX, a MPF encontraria alguma resistência na catequização dessas últimas, que vinham tendo acesso à cultura e, principalmente, às demandas femininas que faziam parte do contexto internacional:

A MPF preocupou-se também muito com o que liam as filiadas, proibindo-lhes determinados livros e divulgando entre elas a "boa" literatura, na qual se incluía, em primeiro plano, a portuguesa, de Gil Vicente a Júlio Dinis, cancioneiros e poemas - religiosos e nacionalistas -, sobretudo de Correia de Oliveira e do padre Moreira

${ }^{41}$ Este cenário só se altera a partir dos anos 1950, quando se torna incontornável "a atração das raparigas pelo trabalho fora do lar", uma vez que os índices educacionais já regulavam em porcentagem o número de meninas e meninos na escola. "Começaram então a surgir, na Menina e Moça, artigos sobre o assunto, onde se alertava as jovens para não desdenharem uma profissão, dado que algumas talvez nunca se casassem e que outras podiam ter de vir a enfrentar a viuvez. A escolha deveria, porém recair sobre profissões "femininas" convenientes: cursos de professorado primário, enfermagem e de educação infantil" (MADEIRA, 2007, p. 302). 
das Neves, assíduos colaboradores das revistas da MPF. Esta também se preocupava com os filmes que as filiadas viam, nomeadamente com cinema americano, que veiculava, entre as jovens das classes média e alta das cidades às quais a MPF se dirigia prioritariamente, valores mais livres e um modelo oposto àquele que o Estado Novo pretendia para as mulheres. (MADEIRA, 2007, p. 296)

Além das disciplinas em sala de aula, também o jornalismo atuou como meio importante pra inculcar a ideologia nacional cristã, ao transmitir valores que iam de encontro com os interesses do Estado Novo. ${ }^{42}$ Processo parecido com o que ocorria no Brasil, embora aqui o liberalismo encontrasse menos resistência e haveria, portanto, um forte impacto, como procuramos apontar, entre o que era defendido pelas revistas femininas enquanto valores para as mulheres e o que as diversas propagandas traziam como mensagem para persuadir a compra de produtos.

Ainda assim, é importante evidenciar que o regime salazarista atuava, segundo Madeira, em tensão, pendendo sempre para o que seria mais eficaz para sua manutenção, ainda que a política para mulheres tenha mantido por muito tempo a sustentação da função social da mulher como esposa, mãe e dona-de-casa, o que encontrará ecos mesmo quando, mais adiante, as diretrizes para as mulheres, tendo em vista as novas dinâmicas contextuais, tenham sido alteradas:

$O$ regime salazarista manteve-se sempre em tensão entre dois grupos de atitudes que também se fizeram sentir na OMEN e nas MP: entre a mobilização e o enquadramento das mulheres e dos jovens, por um lado, e a desmobilização e despolitização dos portugueses, por outro lado; entre a recusa do totalitarismo, por um lado, e a vontade estatal de criar um "homem novo" e de arregimentar e enquadrar segmentos da população, por outro lado. Por ter sabido manter essas tensões em equilíbrio, por escolher frequentemente terceiras vias e apoiar-se ora num ora no outro dos pólos das contradições no seu seio sem nunca eliminar nenhum, o Estado Novo soube durar. (MADEIRA, 2007, p. 304)

${ }^{42}$ Cf. MADEIRA, 2007, p. 297. 
Ainda assim, apesar das contradições que estavam presentes nessa política que buscava apoiar-se em grupos que a fortalecesse, é sensível que o papel das mulheres, desde sua instrução educacional, estava associado sempre à família e, consequentemente, ao casamento.

\title{
O casamento
}

Tendo em vista esta base ideológica em que se consolidava o Estado Novo, que pretendia substituir a ideia de indivíduo pela noção de papeis desempenhados na família, na qual o regime totalitário tem um de seus tentáculos, Elina Guimarães aponta para a resultante disso numa política para mulheres:

\begin{abstract}
Verificou-se nos anos 30, não apenas em Portugal, mas também por quase toda a Europa, a adesão aos princípios do totalitarismo, que, ao contrário do liberalismo anterior, punha a colectividade acima do indivíduo e, neste caso específico, a família, como um todo, acima dos direitos dos seus membros. Era um retorno ao sistema patriarcal. Na história universal, este período terminou precisamente com a derrota dos países totalitários, em 1945. Mas Portugal conservou-o, teimosamente, contra as correntes internacionais e as modificações sociais. (GUIMARÃES, 1986, p. 567)
\end{abstract}

Assim, tem-se que o casamento se mantém como única possibilidade na vida da mulher, que deveria desempenhar o seu papel de esposa, mãe e dona de casa, uma vez que não seria reconhecida individualmente e, ainda, o reconhecimento de seu desempenho estava atrelado à vida privada. Se, no entanto, algumas conquistas já vinham sendo reconhecidas na luta de mulheres por melhores condições de vida, tais conquistas iriam retroceder com o acirramento das forças ideológicas e repressivas de Salazar. É o que ocorre, por exemplo, com a questão do divórcio, cuja aprovação através da lei republicada de 1910 foi abolida:

Quanto à separação de pessoas e bens, podia ser solicitada no caso de "adultério da mulher", mas só no caso de "adultério do marido 
com escândalo público ou completo desamparo da mulher ou concubina teúda e manteúda do domicilio conjugal" (subl. nosso) . Essa diferenciação de situações consoante ao sexo foi abolida pela Lei do Divórcio republicana de 3 de Novembro de 1910, que possibilitou a separação por mútuo consentimento e estabeleceu a igualdade entre cônjuges quanto às causas da separação. (PIMENTEL, 2001, p. 34)

Portanto, temos que além de manter o casamento como foco de vida das mulheres, cuja vida estava atrelada a ele, o Estado faz a salvaguarda do casamento, recrudescendo o ataque às possíveis tentativas de mulheres que visassem questionar ou resistir ao papel que Ihes era atribuído pelo Estado Novo. Isso será ainda mais adensado pela dificuldade imposta às mulheres ao acesso ao mercado de trabalho, o que as tornava, via de regra, dependentes economicamente de seus maridos.

\section{Trabalho: a dependência econômica}

Embora a ditadura salazarista tenha, nos seus primeiros anos, atentado para os direitos da trabalhadora, restringindo horários, ocupando-se em lançar decretos para a condição da gravidez, ou ainda regulando carga horária da mulher, e pressionando certas empresas que pagavam salários menores a mulheres e crianças, regulamentando por fim o trabalho feminino e o tornando mais custoso para a indústria, o objetivo final era de fato a retirada das mulheres do mercado, o que vai acontecer finalmente em 1934, ano em que Maria Lamas escrevia Para além do amor:

Depois, o Decreto-Lei n. 24 402, de 24 de agosto de 1934, considerou, no seu preâmbulo, que, enquanto houvesse homens desempregados não era "de permitir, em muitas indústrias, o recurso abusivo à mão-de-obra mais barata fornecida pelas mulheres e pelos menores", e deplorou, por outro lado, "as consequências de ordem higiênica e moral" resultantes do facto de as mulheres 
casadas terem de abandonar "os lares para fazer turnos nocturnos nas fábricas". O trabalho feminino passou, assim, a ser permitido só entre as 7 e as 20 horas, nas indústrias, e entre as 9 e as 18 horas nos escritórios, embora estas limitações nem sempre tenham sido cumpridas, com o beneplácito do Instituto Nacional do Trabalho e da Previdência (INTP), que autorizava excepções à lei. Às mulheres foi também impedido o trabalho em certas indústrias tóxicas, uma proibição que, para resolver problemas de desemprego, também se estendeu a outros sectores não tóxicos, entre os quais a indústria de chapelaria, onde as operárias não podiam trabalhar senão na costura enquanto existissem operários inscritos como desempregados nos sindicatos nacionais. (PIMENTEL, 2001, p. 44)

As restrições, no entanto, não eram só estabelecidas com relação ao tipo de profissão que exerceriam as mulheres, senão também pela questão do casamento, uma vez que a mulher que trabalhasse fora do lar ou precisava de autorização para casar quando exercia profissão, quando solteira, ou, uma vez casada, precisava de autorização do marido para exercer a profissão:

\begin{abstract}
Além do impedimento do trabalho feminino em certos sectores $\mathrm{e}$ profissões, havia também restrições de vária ordem impostas a certas profissionais. As professoras primárias tinham que pedir autorização ao MEN para se casarem, enquanto outras profissionais eram impedidas de contrair matrimônio. Entre estas contaram-se as telefonistas da Anglo-Portuguesa Telephone, o pessoal feminino do Ministério dos Negócios Estrangeiros (MEN), as hospedeiras de ar dos Transportes Aéreos Portugueses (TAP) e as enfermeiras dos Hospitais de Civis. ${ }^{43}$ (PIMENTEL, 2001, p. 41)
\end{abstract}

O acesso das mulheres ao mundo do trabalho era assim constrito de diversas maneiras, o que tornava ainda mais problemática a dependência delas do marido.

\footnotetext{
43 "O impedimento do casamento estava relacionado ao controle de mobilidade social. "Em 1967, o Código Civil considerou que a mulher já não necessitava "do consentimento do marido para exercer profissões liberais ou funções públicas, nem para publicar ou fazer representar as suas obras ou dispor de propriedade intelectual" (art. 1676) nem, ainda, ter atividades lucrativas" (PIMENTEL, 2001, p. 42).
} 
Dessa maneira, reforçava-se uma vez mais a ideologia patriarcal, que exigia delas a submissão matrimonial.

\section{O Adultério}

Consolidada dessa maneira as restrições à autonomia da mulher, uma vez que dependiam economicamente do marido quando estavam restringidas às atividades domésticas, ou da autorização desse, se optassem por exercer atividade fora do lar, o casamento tomava ainda um viés mais autoritário no cerceamento à liberdade feminina, não à toa será motivo de diversos questionamentos ao longo do movimento feminista em Portugal. A lógica opressora que assegurava essa restrição estabelecia-se, além da via ideológica que viemos apontando até aqui, também pelas vias legais. E é pela via legal que se materializa a criminalização do adultério.

Assim, o adultério feminino configurava crime (até 1973), cuja penalidade compreendia até dois anos de prisão, ao contrário do masculino, cuja penalidade era multa e isso apenas no caso de o homem levar a amante para a casa da esposa. ${ }^{44}$ Tal situação, como podemos observar, apresenta bastante semelhança com o Brasil, onde também havia a criminalização do adultério feminino, enquanto o masculino era prática aceitável, em consonância com a ideologia patriarcal.

\section{O feminismo tardio português}

Assim como no Brasil, em Portugal as mudanças que se foram consolidando desde o final do século XIX e se tornaram evidentes nas primeiras décadas do XX, também abriram espaço para que insurgisse um primeiro movimento organizado, tomado de diversas frentes, que foi responsável pela a primeira vaga feminista portuguesa:

\footnotetext{
44 CÂNCIO, Fernanda. A grande Revolução esquecida no 25 de abril. Disponível em: << https://www.dn.pt/portugal/interior/a-grande-revolucao-esquecida-do-25-de-abril-5142798.html >>.

Acesso em: 17 out. 2016.
} 
A pouco e pouco desenha-se um movimento e uma corrente de tom nitidamente feminista que, embora elitista no tipo de mulheres que reúne, se reveste, no entanto, de um significado notável pelos esforços que congrega, pela ideologia que difunde, pela unidade visível de objetivos e aspirações que traduz, e pelas expressões e acções concretas que assume e realiza, enquanto movimento organizado. (SILVA, 1992, p. 9)

As frentes organizadas surgem principalmente a partir dos anos 1920, com a firmação da Liga Republicana das Mulheres Portuguesas e, a seguir, da Associação de Propaganda Feminista:

Embora surgido tardiamente, o movimento feminista em Portugal desenvolveu-se e atingiu o seu auge, enquanto ideário, organização, mobilização e reivindicação, na segunda década deste século, não se podendo ignorar o aparecimento, em poucos anos de associações como o Grupo Português de Estudos Feministas (1907), a Liga Republicana das Mulheres Portuguesas (1908/91919), a Associação de Propaganda Feminista (1911-1918), o Conselho Nacional das Mulheres Portuguesas (1914-1947), a Associação Feminina de Propaganda Democrática (1915-1916) e a Cruzada das Mulheres Portuguesas (1916). Comum a todas era a vontade e o empenho em dignificar, modificar e revolucionar o papel da mulher na sociedade de então, apesar de só o Conselho Nacional das Mulheres Portuguesas acabar por ter existência duradoura, interrompida arbitrariamente em 1947, por proibição das autoridades ditatoriais do Estado Novo, quando era sua presidente a escritora e jornalista Maria Lamas. (ESTEVES, 1998, p. 12)

Ainda que como os demais movimentos feministas em dado contexto tenha como foco o sufrágio, e, consequentemente, o reconhecimento da mulher enquanto cidadã, não será só esta questão a enfrentar o feminismo português. Tornam-se espessos como objetivo a questão da educação feminina, que aliás, sofrerá consequência como mencionamos acima a partir das reivindicações de mulheres 
vinculadas ao movimento republicano; assim como a da independência econômica da mulher, principalmente com a atuação da Liga e, posteriormente, da Associação; e entra em pauta o divórcio como direito.

\begin{abstract}
Assim, entre 1907 e 1913, a imprensa operária está semeada de artigos debatendo calorosamente o feminismo e Ana de Castro Osório elabora teorias das mulheres operárias. Por outro lado, as 500 aderentes da Liga Republicana das Mulheres Portuguesas exigem, a partir de Outubro de 1910, a igualdade na família, a independência econômica da mulher, o divórcio, a educação cívica e sobretudo o direito da mulher ao voto. (BELO et al.; 1987, p. 263)
\end{abstract}

Trata-se aqui também de um feminismo que não atuará enquanto movimento de maneira radical, sendo "sempre um movimento moderado, nunca declaradamente subversivo nem violento, mais atento à satisfação das suas reivindicações pela força de persuasão, do direito e da educação, do que pela força dos gritos e das manifestações" (SILVA, 1992, p. 10). Ainda, acresce-se a isso sua formação a partir de um grupo de mulheres da elite portuguesa que tiveram seu acesso às esferas públicas assegurado em consequência do estatuto social de suas famílias. Em tudo, portanto, caminha-se em paralelo ao feminismo brasileiro, e não só ao brasileiro uma vez que isso era o arcabouço da primeira onda feminista em diversos lugares do mundo. Ainda assim, como o "feminismo comportado" no Brasil, a luta das mulheres não prescinde do papel social da mulher enquanto esposa e mãe, mas, uma vez assegurada alguma inserção no sistema educacional, são abertas fissuras através das quais o movimento é fortalecido:

A questão da instrução feminina surgiu em Portugal no século XIX, mais como uma inquietação sentida por alguns sectores ilustrados do que como uma preocupação latente da sociedade. A tomada de consciência da sua necessidade por parte dos poderes públicos foi um processo moroso que se procurou associar à modernização do Estado, sendo inclusive encarado como um sintoma do progresso civilizacional. A instrução feminina avançou, acompanhando a valorização das funções tradicionais da mulher, sobretudo no seu papel de mãe. A grande preocupação centra-se nas gerações 
futuras e na grande influência que a mãe, enquanto "escultora de almas", poderia vir a ter na "construção de um cidadão futuro". (...) O acesso das mulheres à instrução contribuiu, no entanto, para aumentar a sua capacidade reivindicativa quer no que respeita ao acesso a todos os níveis de instrução, quer quanto a uma participação mais activa na vida social, política e econômica. (SILVA, 1992, p. 82)

Em Portugal, assim como em outras partes do mundo, como o Brasil, o feminismo enfrentou sérias resistências, principalmente a partir da composição política salazarista, que buscava, veementemente, enfraquecer qualquer luta das mulheres pela conquista de direitos enquanto cidadãs, opondo-se à independência feminina através da ideologia patriarcal. Ainda assim, tem-se, no início do século $\mathrm{XX}$, representantes radicais para a época, como é o caso de Ana de Castro Osório ${ }^{45}$, que em 1905, pontuava em seu livro Às mulheres portuguesas:

\begin{abstract}
Feminismo: é ainda em Portugal uma palavra de que os homens se riem ou se indignam, consoante o temperamento, e de que a maioria das próprias mulheres coram, coitadas, como de falta grave cometida por algumas colegas, mas de que elas não são responsáveis. (OSÓRIO, 1905, p. 11)
\end{abstract}

Ana de Castro Osório destaca-se por sua atuação neste início de século, uma vez que diante da conturbada situação política de Portugal, reivindicou direitos para a mulher portuguesa: o direito à educação, ao divórcio, ao voto (restrito) e ao exercício de uma profissão, ainda que não fugisse à regra de defender o papel da mulher na família, o que se explicaria diante do conservador contexto português:

Em suma, enquanto publicista feminista Castro Osório dá a conhecer ao país o substancial atraso da mentalidade de mulher portuguesa relativamente às suas congêneres europeias por falta de uma educação e instrução adequadas à sua classe social e estado

\footnotetext{
${ }^{45}$ Ana de Castro Osório (1872-1935) foi escritora e fundadora do Grupo Português de Estudos Feministas, da Liga Republicana de Mulheres Portuguesas e da Associação de Propaganda Feminista. Colaborou na elaboração da Lei do Divórcio de 1910. Cf. CORDEIRO, 2012.
} 
civil. A sua luta feminista enfoca-se na alfabetização da mulher para a tomada de consciência da necessidade de luta pela reivindicação dos direitos femininos. No entanto, a autora sublinha veementemente o papel da mulher na família e a sua função maternal, suplantando-a relativamente ao exercício de uma profissão fora do espaço doméstico, particularmente no caso da burguesa mãe. Deste modo, a mãe burguesa é aquela que conta para o regime republicano e para Castro Osório (enquanto protagonista das suas novelas e romances) e cabe a ela contribuir para 0 desenvolvimento de Portugal e preservação da identidade nacional. Nesse sentido, a autora acaba proclamando um feminismo conservador e restritivo, contudo, o único que se ajusta ao seu tempo numa sociedade conservadora com a portuguesa. (CORDEIRO, 2012, p. 23)

Embora tenha fundado com Maria Veleda ${ }^{46}$ a Liga nos anos 1900, rompe com esta quando denotada na organização ideais feministas diferentes das que defendia, uma vez que a organização apresentou-se reticente "em defender o sufrágio"47, segundo João Esteves (1998, p. 23), questão que foi ainda mais inflamada pela proposta surgida na Liga de revisão do estatuto que impunha respeito por todas as religiões e todas as crenças das sócias, ao que Castro Osório se opunha. Assim, ocorreu uma ruptura que ocasionou o surgimento da Associação de Propaganda Feminista, em 1911.

Da associação faria parte Carolina Beatriz Ângelo ${ }^{48}$, que foi a primeira e única mulher a votar nas eleições para o parlamento da $1^{\text {a }}$ República Portuguesa, através de uma brecha da primeira Lei Eleitoral do Regime Republicado em que não era explícito o veto às mulheres ao voto. No entanto, após circularem imagens suas exercendo o direito de voto feminino, o Partido Republicano alterou a lei e proíbiu mulheres de votarem. Nas diretrizes da Associação, ficava estabelecido:

\footnotetext{
${ }^{46}$ Maria Carolina Frederico Crispim (1871-1955) foi jornalista, professora e feminista e defendeu o direito das mulheres assim como a educação infantil, sob os ideais republicanos. Escreveu Emancipação feminina.

${ }^{47}$ Maria Veleda chegou a se assumir anti-sufragista, porque era contrária à permissão do voto feminino apenas para as mulheres da elite portuguesa, dizia que defenderia o voto feminino se a sua concessão fosse a todas as mulheres portuguesas. Cf. ESTEVES, 1998, p. 23.

${ }^{48}$ Carolina Beatriz Ângelo (1878-1911) era médica e fez parte da Liga e compôs a Associação. Morreu aos 33 anos, no mesmo ano em que votou, vítima de um problema cardíaco.
} 
Em escrito datado de 24 de Março de 1912, esta elucidava que o fim da Associação era "elevar a mulher pela educação e pela instrução": com a educação torná-la Perseverante, defensora da Verdade e da Justiça que era devida; a instrução serviria para que a mulher tomasse "o seu verdadeiro lugar de mãe de família, consciente e culta, isto é: dirigente e moralizadora da sociedade". A par da insistência em valorizar o papel da mulher no seio da família, exaltando-se a importância da mulher-mãe no seio da família, exaltando-se a importância da mulher-mãe como formadora das "almas infantis, que são a sociedade do futuro", surgia a ideia de que só outra preparação Ihe proporcionaria a independência econômica, passo indispensável para que se tornasse um ser verdadeiramente livre. (ESTEVES, 1998, p. 31-32)

Não obstante a questão do papel da mulher como mãe, a Associação foi importante na defesa dos direitos das mulheres, sendo a primeira organização a levar a palavra Feminista para o seu nome, o que demonstrava, já, uma posição desafiadora para uma época em que o feminismo era ainda alvo de ridicularizações em Portugal. A Associação teria ainda um caráter humanista, suas colaboradoras argumentavam que o feminismo era humanismo, defendendo ideais de igualdade entre homens e mulheres, não predomínio da mulher, o que era mencionado em diversos discursos, mas "enjeitavam a obediência, a sujeição e a subserviência da mulher ao homem" (ESTEVES, 1998, p. 38), afirmavam ainda que a questão feminista era econômica, buscando um acesso ao trabalho pelas mulheres que ocasionaria tal igualdade. Ainda assim, a Associação não realizava manifestações nas ruas e tampouco tinha tantas associadas, trabalhando mais através da persuasão para a qual utilizavam os acessos sociais que tinham os seus principais nomes, como Castro Osório.

Com a Primeira Guerra Mundial, ocorreu um enfraquecimento das questões feministas, uma vez que as atenções se voltaram para os caminhos da guerra. Apesar da luta da Associação, o governo Republicano não cedeu o direito ao voto à mulher portuguesa, o que Salazar fez nos anos 1930.

Outra importante organização de mulheres foi criada também durante a Primeira República: o Conselho Nacional de Mulheres Portuguesas (CNMP), em 
1914, cuja fundadora e primeira presidente foi Adelaide Cabete ${ }^{49}$. Cabete era uma grande oradora e representava o Conselho em eventos feministas internacionais, em viagens que financiava com recursos próprios, uma vez que, diferente de outras organizações representativas europeias, o Conselho português não tinha dinheiro. O Conselho representou uma ruptura com a postura pacifista dos movimentos feministas ligados às demandas republicanas, porque entendia que a conquista de direitos deveria partir das próprias mulheres, já que os homens não abririam mão dos seus privilégios. O CNMP não se declarava como um movimento político (no sentido partidário do termo) tampouco tinha vínculos religiosos claros, o que também o fazia se diferenciar dos anteriores, que eram ligados ao Partido Republicano, por um lado, e à maçonaria, por outro; além disso, não usava enfaticamente, como a Associação, a palavra Feminista.

Entre os seus objetivos constava a luta por direitos das Mulheres, principalmente os relacionados ao acesso à educação, e embora enfrentasse divergências entre as mulheres que faziam parte desse, conseguiu quebrar o quadro de cisões que vinha sendo um problema para todas as organizações feministas anteriores. O CNMP teve ainda uma existência duradoura em comparação aos outros movimentos, uma vez que perdurou até o final dos anos 1940, em pleno regime salazarista ${ }^{50}$, quando foi fechado em repreensão de Salazar à Exposição de Livros Escritos por Mulheres, organizada então por sua presidente no período: Maria Lamas.

Nos anos 1930, portanto, apenas o CNMP funcionaria, de certa maneira, como oposição às organizações femininas constituídas pelo governo de Salazar, em prol dos direitos das mulheres em busca de uma maior igualdade. É notável, no entanto, que o Conselho trazia em sua conduta ideológica boa parte do que vinha sendo construído pelas diversas organizações feministas anteriores, bem como as perspectivas de suas diversas lideranças e sócias. Também é evidente a preocupação do Conselho em denunciar as difíceis condições em que as mulheres

\footnotetext{
49 Adelaide Brazão Cabete (1867-2935) foi médica. Iniciou seus estudos após seu casamento com um republicano que lhe estimulava a estudar. Formou-se na faculdade de medicina aos 33 anos. Em 1926, já viúva e em desacordo com os novos rumos políticos de Portugal, mudou-se para Luanda, onde, em 1933, foi a primeira mulher a votar no referendo constitucional.

50 "Apesar das dificuldades iniciais e do processo atribulado e arbitrário que constituiu a sua proibição e encerramento, o historial do Conselho foi ímpar, não só pela invulgar duração, parte dela sobre um regime ditatorial, como abarcou gerações diferentes de sócias, a maioria republicana, maçônica e oposicionista ao Estado Novo." (ESTEVES, 2006).
} 
portuguesas viviam, principalmente as mais pobres, assim como foi significativa a sua atuação para apresentar o trabalho de mulheres profissionais. Não foi com outro propósito que Maria Lamas realizou através do Conselho a Exposição de Livros Escritos Mulheres, que apresentou livros sobre os mais diversos assuntos escritos por mulheres do mundo todo ${ }^{51}$, além de escritoras ficcionistas, porque havia uma preocupação em apresentar a atividade intelectual de mulheres nas mais diversas áreas do conhecimento que resultaram em publicação no suporte livro.

\section{Para uma análise da narradora}

Uma vez exposta a questão da ideologia que norteia esta análise e apresentados sucintamente os contextos em que se confabulam as vozes narrativas, podemos adensar novamente a análise, observando mais intimamente a organização pautada pelas autoras implícitas nas obras que delinearão a perspectiva das narradoras.

\footnotetext{
${ }^{51}$ Em seu catálogo, disponível na Biblioteca Nacional, em Lisboa, consta a presença de Lúcia Miguel Pereira como ensaísta e romancista, com as obras: Amanhecer, Machado de Assis - Biografia e crítica; A vida de Gonçalves Dias - biografia; Em Surdina; Livro de Centenário de Eça de Queiroz; Machado de Assis - estudo crítico e biográfico
} 
CAPÍTULO IV - As autoras implícitas e as narradoras 


\section{A narradora e a autora implícita: ideologia e história na estrutura narrativa}

Para analisarmos a narradora e suas configurações mais detidamente, faz-se fundamental apontar para uma categoria narrativa que corrobora essa abordagem: a autora implícita. O conceito de autor implícito é de Wayne Booth, que refutou, assim como outros teóricos, a exemplo Kayser, com quem dialoga, a não diferenciação entre o autor e o narrador, ou seja, entre aquele que elabora a obra e aquele que é parte da obra, todavia ele faz uma distinção ainda maior ao apontar como duas entidades distintas o autor-homem e o autor-implícito. Para Booth, analisando as técnicas narrativas, há o autor, a pessoa real na concepção da obra, e o autor, entidade que se impõe ao texto e transparece nele pela organização e manipulação da estrutura narrativa. É possível apreender o autor implícito pelo posicionamento do narrador, que dele faz uso para beneficiar a estrutura literária. O autor implícito surge, assim, como um alter ego do autor na obra; para Booth o autor apresenta seu alter ego ou uma versão de si em cada obra que produz.

Tal como as cartas pessoais de cada um de nós implicam diferentes versões de nós próprios, dependendo das diferentes relações que temos com cada correspondente e da finalidade de cada carta, o escritor assume ares diferentes, dependendo das necessidades de cada obra. (BOOTH, 1980, p. 89).

Assim, o autor implícito se transveste de acordo com sua finalidade, assumindo em sua manipulação as diretrizes dos elementos que compõem a narrativa. O autor implícito, ainda, escolherá o tipo de foco narrativo ampliando ou restringindo o limite de observação do narrador, e configurando os pontos de cegueira, que em conjunto resultarão em uma intenção. O autor implícito então terá duas formas de disfarce: a voz em terceira pessoa e a voz em primeira pessoa. Esse fator será determinante para a identificação de ideologia, o que incidirá no comportamento do narrador: 
(...) para além e para aquém do ponto de vista do narrador romanesco (em primeira ou em terceira pessoa), uma ótica implícita se assenta no horizonte textual. O ponto de vista conferido ao narrador não é aquele que dá forma e compleição ao universo criado: ele é um dos muitos olhos que o inauguram e dão-lhe vida. (DAL FARRA, 1978, p. 49)

A relevância do ponto de vista do narrador está na sua função enquanto ficção de conduzir o olhar, de maneira que indica o acesso para o desvendamento do "ângulo da visão moral, e não apenas técnico, do qual a história é contada", segundo BOOTH (1980, p. 280).

\begin{abstract}
Na verdade, a ótica avaliadora percorre todos os labirintos textuais e surge, posteriormente, ao leito, como a marca da existência do autor-implícito, que por trás dos disfarces e por baixo do cenho atento com que carrega a responsabilidade dos seus mil olhos, decide o percurso das vistas e das bocas que manipula. (DAL FARRA, 1978, p. 49)
\end{abstract}

Parece-nos evidente que na relação entre autoras implícitas e narradoras ficará exposta a ideologia presente nos romances analisados, ideologia essa que se fixa ou se distende de acordo com o posicionamento da narradora. Assim, no romance de primeira pessoa, através do discurso do narrador, a ideologia se torna visível, mas por isso mesmo fixa, segundo Dal Farra, uma vez que a "avaliação está sempre explícita e garantida pelo discurso do narrador", dessa forma, a sua voz contínua resulta numa "estabilidade ideológica" (1978, p. 51). No entanto, esta estabilidade será abalada pela distância do narrador da personagem que vivencia o fato, o que pode ocorrer como em Amanhecer, quando Maria Aparecida narradora apresenta a sua história a partir da Maria Aparecida mais jovem, a quem agora, no ato de narrar, analisa. Esse processo permite então o confronto de ideologias fixas uma apresentada pela narradora e outra apresentada pela protagonista.

Evidentemente, a narrativa em terceira pessoa, por sua vez, abrirá espaço a esse confronto que, apontando para uma "possibilidade de persuasão de uma ideologia, pode, por sua vez, encobrir outros sistemas semânticos e desempenhar a mesma função mistificante que aparenta destruir" (DAL FARRA, 1978, p. 52). 
Importa, significativamente, que a escolha do foco narrativo determina um ponto de vista e, por consequência, também uma "explícita tomada de partido" (1978, p. 52). Preocupa-nos aqui apontar para esta tomada de partido, ou dimensão ideológica que subjaz nos romances estudados, a partir das vozes que dialogam entre si, intercambiando-se.

Em seu ensaio A room of one's own (1928), Virgínia Woolf aponta para a necessidade de alguma independência econômica da mulher para que essa possa escrever. Mas vai além e propõe um programa para as mulheres escritoras: 1 . inventar o novo (já que não há tradição, uma vez que a produção está vinculada aos homens); 2. atentar-se para os detalhes de uma vida comum de mulher, uma vida que todas as mulheres levariam, iluminando isso através de si mesma, o que chamará de compromisso com a verdade.

Ainda falta que todas essas vidas infinitamente obscuras sejam registradas, pensei, dirigindo-me a Mary Charmichael como se ela estivesse presente; e prossegui no pensamento pelas ruas de Londres, sentindo na imaginação a pressão da mudez, o acúmulo da vida sem registro, seja das mulheres nas esquinas, de mãos na cintura e anéis incrustrados em dedos gordos e inchados, falando e gesticulando no ritmo das palavras de Shakespeare; seja das vendedoras de violetas ou de fósforos e das velhas encarquilhadas paradas sob as marquises; ou das moças cujo rosto, como ondas sobre o sol e as nuvens (...). Você terá que explorar tudo isso, disse eu a Mary Carmichael, (...). Acima de tudo, você deve iluminar a própria alma, com suas profundezas e superficialidades (...). E há também uma moça atrás do balcão - eu preferiria sua história real à centésima quinquagésima vida de Napoleão ou o septuagésimo estudo sobre Keats e seu uso da inversão de Milton que o velho professor Z. e seus semelhantes estavam escrevendo ultimamente. (WOOLF, 2015, p. 128)

Apesar de sabermos que tanto Lúcia Miguel Pereira quanto Maria Lamas foram leitoras de Virgínia Woolf, não é possível apontar que elas estejam objetivamente respondendo a esse programa, no entanto, parece-nos perceptível que nos quatro romances aqui analisados se olha justamente para essa mulher 
comum e dela subtrai-se expediente para a criação, o que aponta para uma primeira faceta ideológica das autoras implícitas presentes nos textos: o ponto de vista será voltado para as mulheres. Mais do que isso, aponta-se para a necessidade de inscrição dessa mulher, principalmente em Para além do amor onde isso é enunciado nas primeiras páginas, a partir de uma determinada verdade sobre a mulher. A verdade, supõe-se, recai objetivamente sobre as ideologias que irão ser norteadoras das narrativas. Assim, protagonistas, narradoras e autoras implícitas irão apontar para suas perspectivas sobre a função social que lhes é imposta. E serão refletidas nas outras assim como serão reflexos das outras mulheres que compõem as narrativas.

Nos romances analisados nesta tese buscamos acompanhar na tessitura das histórias narradas as ideologias que confirmam ou às quais se contrapõem e que estipulam a presença de uma narradora. A dimensão ideológica que norteia estas narrativas, já sabemos, é composta por uma posição dialética que justapõe aspectos dimensionados à condição da mulher e que irá corroborar o posicionamento dessas narradoras e, consequentemente, desvendará as suas autoras implícitas. Assim temos que na medida em que apontam para suas respectivas escolhas, muito embora algumas circunstâncias estejam ainda condicionando essas narradoras, abrem fissuras num modelo ideal sob contestação diante de uma configuração ideológica que tenta impor às mulheres, nos anos 1930, a ordenação de uma volta ao lar. A mulher-modelo então seria aquela totalmente imersa na esfera privada, regulada por sua função de esposa e mãe, cenário este que só pode ser configurado através da instituição casamento, uma vez que o casamento garante tal ordenação.

Justamente sobre essa estrutura incidirão todas as narrativas: Maria Luísa e Para além do amor acerca da consciência feminina de sua opressão já que, como mulheres casadas, irão observar a si a partir da experiência do adultério; Amanhecer e Ilha Verde acerca da recusa ao casamento, que, para tanto, só é possível com a mudança do locus enunciativo com relação às duas primeiras protagonistas: no primeiro caso, não se trata de uma mulher burguesa, no segundo não se trata de uma portuguesa. Temos então coincidências e divergências nessas estruturas que parecem compactuar com o contexto histórico em que foram elaboradas. Para fins desse momento comparativo, falaremos primeiro das escolhas 
do foco narrativo, para depois adentrar uma análise que teça sentido enfatizando a história para melhor observarmos o processo ideológico presente.

Há, como já pudemos observar, uma mudança no foco narrativo escolhido: Lúcia Miguel Pereira e Maria Lamas apresentam, no arcabouço ficcional desta pesquisa, um romance em primeira pessoa e um em terceira. No entanto, é notável que invertem suas preferências no decorrer do tempo aqui escolhido para análise; assim, no início dos anos 1930, Lúcia escolhe o foco narrativo em terceira, enquanto Maria Lamas em primeira, para tratar da mulher casada; e no final dos anos 1930 , Lúcia passa a usar a primeira pessoa enquanto Maria Lamas a terceira, para tratar da mulher que irá se recusar a casar. Portanto, enquanto as autoras implícitas de Lúcia Miguel escolhem observar (comentando) a mulher casada e dar voz (autônoma) a mulher que se recusa a casar, as de Maria Lamas farão exatamente o contrário.

Tal fator irá apontar para uma escolha de perspectiva da autora implícita através da qual os romances serão lidos. É óbvia, porque correspondente na voz de suas protagonistas, a presença de uma narradora nos romances contados em primeira pessoa. Essa característica implica em uma opção de ordenação que se edifica, principalmente, pela máscara da narradora em personagem, que camufla ainda mais a presença da autora implícita. Temos tal configuração tanto em Para além do amor como em Amanhecer:

O autor-implícito recria o seu próprio relacionamento com as suas máscaras através do relacionamento que o narrador mantém com as personagens: na distância ou proximidade com que as observa, na simpatia ou antagonismo com que as concebe na própria imprevisibilidade que separa o projeto do narrador da sua execução. O autor-implícito dramatiza no romance de primeira pessoa a origem e o desenvolvimento de sua ficção.

Mas "imitando" a própria realidade em que se circunscreve, ele se distancia mais e mais. Quando o narrador veste a máscara das personagens, o rosto do autor-implícito já se perdeu, para o leitor, nas espessuras dos disfarces. E, por isso, mais camuflado e livre, ele pode transitar silenciosamente na profundidade ou na superfície da obra, distribuindo-se e irradiando-se em tentáculos que a enlaçam. Sua intenção, que se desgasta e toma percursos 
diferentes como aquela do narrador, confere-lhe, por fim, a sua imagem completa, que se desenha não através do que ele queria dizer, mas através do que ele disse. (DAL FARRA, 1973, p. 42-43)

Ainda que tenhamos essa semelhança da escolha de foco narrativo em primeira pessoa, os romances apresentam diferenças fundamentais, que estão vinculadas às suas condicionantes históricas. Temos assim que em Para além do amor, Marta conta a sua história e através dela podemos notar o seu processo de conscientização com relação à opressão de gênero que incide sobre si. A autora implícita dá voz à mulher casada comprometida em contar a sua verdade, para isso imputa à narrativa uma dinâmica de diário. Contando sua história "por dentro", a partir exclusivamente de sua visão de mundo, Marta estipula sua condição de maneira ativa, não passiva. Assim, o primeiro plano narrativo apresenta as suas reflexões. O mesmo processo é observável em Amanhecer, quando é Maria Aparecida a dar voz a sua própria história.

As narradoras ganham aqui espaço para autonomia de reflexão que apresenta um processo de conscientização dos seus lugares sociais. No entanto, se a primeira está casada e irá repensar sua vida a partir de uma experiência adúltera, a última opta por não se casar, ainda que esta opção seja de alguma maneira, e não exclusivamente, reflexo das escolhas do homem com quem se envolve. Apresentam assim flexões e inflexões específicas, que thes são possíveis graças ao direito à voz. Não há espaço nessas narrativas para que julguemos as ações das protagonistas que não a partir dos seus próprios pontos de vista. Ocorre que tanto o adultério de Marta quanto a relação não atrelada ao casamento de Maria Aparecida serão apresentados pelas suas perspectivas e, portanto, há chance de se verificar os meandros desses posicionamentos a partir da atuação dessas mulheres. São narradoras, não há dúvida, e suas dimensões ideológicas são estipuladas pelas autoras implícitas aqui disfarçadas.

A autora implícita de Para além do amor dá direito à voz a uma protagonista que irá contrariar as ordens sociais do momento, em partes. Em sua experiência não há culpa, que como vimos era angariada pelo catolicismo português que respondia à ideologia patriarcal de submissão ao marido, presente em toda a estrutura política para a mulher portuguesa que já vinha sendo proposta por Salazar. Contraria, assim, a ordem posta acerca do comportamento feminino no 
casamento e, ainda, aponta para a não criminalização desse comportamento, uma vez que a perspectiva narrativa está condicionada ao seu ponto de vista. Não é o bastante. Marta também escolherá a construção coletiva com outras mulheres diante do amor ideal que está configurado na maneira que distingue sua relação com Gabriel. Com a preponderância desses posicionamentos da protagonista, temos na estruturação da narradora a dialética (movida também pela contradição) dos conflitos sociais do período, uma vez que ainda que aponte para a sua autonomia, a narradora também fará uma escolha pela educação do filho, condicionante do comportamento feminino, mas em sua defesa essa educação será também resultante de sua conscientização, que assegura o tom subversivo, pois que se propõe a disputar com o marido a ideologia a que responderá o filho. Além disso, em não prescindindo de sua função de esposa e mãe, aponta para certa autonomia que pode conquistar através do trabalho com outras mulheres. Diante disso, parece a tudo corresponder às reivindicações feministas do período em Portugal, uma vez que negocia as suas funções; e ainda impõe ao seu comportamento uma insubmissão ao marido que se apresenta como figuração do patriarcal.

Maria Aparecida, em Amanhecer, também vai tomando consciência de sua opressão ao longo da narrativa, ajudada, a princípio, por Antônio, mas não totalmente dependente deste uma vez que apresenta um pensamento emancipado, e crítico, com relação a ele em diversas passagens narrativas. Maria Aparecida opta por não casar, e muito embora questione essa opção, a narrativa apresenta diversos cenários devidamente organizados pela autora implícita e observados pela narradora em que a instituição casamento ou não funciona, ou é falha com as mulheres, caso melhor representado por sua mãe. Diante disso, temos na voz da narradora as observações dessa situação, ao mesmo tempo em que verifica criticamente que será ela própria, por sua escolha autônoma, vitimada por uma sociedade à qual se recusou cumprir as funções que lhe foram determinadas. Questiona-se assim o casamento e a família, principalmente porque Antônio lhe impôs isso. Mas não é apenas isso. Maria Aparecida vai, ela mesma, identificar em Antônio a figuração do patriarcal naquilo que ele tem como poder sobre ela, que é um poder sobrecarregado dos privilégios sociais que operam na relação homem e mulher na sociedade de ideologia patriarcal, independente da conjunção em que se dê tal relação. Assim, a narradora aponta para isso e é ela própria elaborada nessa 
contradição. Recusa mais de uma vez se casar com outros homens, ao mesmo tempo em que não vislumbra desfecho feliz na relação que escolheu, uma vez que sua autonomia não implica em total independência e, ainda, provoca isolamento social. Maria Aparecida também aponta para uma defesa, em partes, da ideologia feminista na época. No final dos anos 1930 no Brasil também há um recrudescimento autoritário sobre a vida das mulheres, que recebem como sua principal função o papel social de esposa e mãe. Maria Aparecida corresponde assim a certa perspectiva feminista, questionando principalmente a ideologia patriarcal, mas se deixa observar enquanto resultado de um feminismo imposto apenas em suas bases teóricas, uma vez que impossível de ser experimentado sem uma punição social. Suas escolhas correspondem à ideologia feminista do período, em oposição à ideologia patriarcal, suas reflexões, no entanto, já atuam criticamente a essa dimensão mais teórica do que prática no feminismo vigente, sem, no entanto, abster-se de observar a perversidade da ideologia que restringe a vida das mulheres.

Se temos as marcas ideológicas que aqui defendemos que correspondem a uma perspectiva de gênero que apresentariam uma narradora, o foco narrativo em si mesmo já define esse posicionamento nesses dois romances. O mesmo processo não ocorre, evidentemente, em Maria Luísa e $A$ llha Verde, que serão narrados em terceira pessoa.

É inegável que nos livros de Lúcia Miguel Pereira pairem, sob um jogo dialético, o conservadorismo de uma determinada tradição familiar ao mesmo tempo em que se questiona o papel social da mulher sendo correspondido apenas como dentro das determinações do modelo mãe e esposa. Maria Luísa, neste sentido, parece-nos ainda mais exemplar do que Amanhecer. Em Maria Luísa, a autora implícita determina uma narradora em terceira pessoa que irá acompanhar detalhes da personagem e que se deixará entrever como narradora a partir da sua perspectiva que indica posicionamentos ideológicos.

Maria Luísa irá corresponder, na primeira metade do romance, exatamente às exigências conservadoras que se sobrepunham à mulher de 1930 no Brasil. Às voltas com as novas organizações sociais que se subscrevem nas primeiras décadas do século $\mathrm{XX}$, as mulheres passam a reivindicar direitos, uma vez que já não estavam mais tão enclausuradas pelo sistema patriarcal e agora tinham acesso à vida pública e podiam, assim, atentar-se para os novos acontecimentos. Dessa 
maneira, o casamento se torna alvo de críticas extensas por parte das mulheres, conforme nos demonstra Besse (1999), que extrapolam os limites do lar para tomar uma dimensão pública. Diante disso, há uma resposta conservadora, que aponta as novas tendências como desmoralizadoras, reverberada também por mulheres. É notável, entretanto, que alguns temas se sobreponham a outros, como é o caso, por exemplo, do adultério, que, conforme já expomos, torna-se um assunto obsessivo para os críticos homens em resposta à insatisfação feminina com as diretrizes da vida conjugal.

Tendo isso em vista, parece-nos bastante relevante que a escolha da autora implícita por uma protagonista que, em correspondendo àquele modelo conservador que era enaltecido na época, seja, ela, muito superficial. Tal efeito, como procuramos apontar, é possível principalmente pelo recurso de distanciamento da narradora, que a autora implícita organiza durante toda a primeira narrativa. Essa narradora, portanto, apresenta-se de forma crítica ao modelo ideal, e para isso não prescinde o uso de comentários, muitas vezes forjados pela ironia. Assim, a distância entre narradora e protagonista e os comentários da narradora norteiam uma crítica àquilo que corresponde à ideologia patriarcal.

No entanto, é justamente depois de cometer o adultério que Maria Luísa ganha profundidade, uma vez que a partir daí a narradora se aproxima. Nessa disposição organizada pela autora implícita, temos que fica em evidência uma crítica à correspondência do modelo-ideal, ao mesmo tempo em que é a partir do "assunto obsessão" ${ }^{25}$ da época que a protagonista irá tomar nova dimensão do seu papel, em perspectiva compartilhada com a narradora. Ao desfazer a vertente irônica e renunciar aos comentários, a narradora na segunda parte da narrativa aproxima-se da protagonista e evidencia uma clara opção da autora implícita por assinalar que o adultério, considerado crime para uma mulher casada segundo o moralismo da época, não configurará um crime no romance, senão uma reação também à sistematização da vida da mulher.

Diferente, todavia, de Para além do amor, o adultério, neste caso, não será de maneira alguma neutralizado no seu sentido negativo, uma vez que a culpa que é organizada na protagonista e transplantada em texto através da ajuda da narradora é não só manifesta como se torna o grande foco de toda ação narrativa.

\footnotetext{
${ }^{52}$ Cf. BESSE, 1999, p. 49.
} 
No entanto, ele será motivador de uma consciência que antes não existia em Maria Luísa e é através, justamente, desse processo de conscientização que narradora e protagonista passam a compartilhar perspectiva. Assim, ainda que admitamos que há o conservadorismo na defesa da família e de uma moral, evidentemente, católica, organizada por essa culpa da mulher em relação ao seu desejo, também há, nessa organização escolhida pela autora implícita, uma exposição de que o adultério tira a protagonista e a narradora do lugar comum para lhes arrogar uma nova ordem, que não é consolidada em ruptura com seu papel social, especificamente, mas que serve para questioná-lo. Nesta estrutura narrativa, portanto, a ordem que parecia obedecer à estrutura social que está posta no contexto em que se é exigida a submissão da mulher é invertida, a partir do que é criminalizável para o modelo ideal, e que aqui não o será. A narradora não contesta mais a protagonista, encaminhando-se em confluência de ponto de vista que sugere que ambas compartilham também os mesmos questionamentos com determinada ordem, ainda que restringidas por uma dinâmica com a qual não é possível romper totalmente.

Por sua vez, em $A$ llha Verde, também é apresentado o ponto de vista em terceira pessoa, e a autora implícita opta por uma narradora mais observadora, que tece poucos comentários, mas que assumirá uma perspectiva que, se por um lado, não coincide totalmente com a da protagonista, tendo em vista que se trata de uma estrangeira, irá identificar-se com o lugar social da mulher, uma vez que, nos momentos em que deixa de ser exclusivamente observadora, sua crítica é tecida principalmente com o comportamento que configura a ideologia patriarcal presente na narrativa. Assim, a narradora não estabelece um viés crítico negativo com relação à Ilonka ou à Maria Luíza, mas deixará entrever a crítica às personagens masculinas naquilo que expressam de controle sobre a mulher.

Além disso, a personagem "exótica" que assume o papel de protagonista irá ela ser uma alternativa viável para se discutir os limites que o conservadorismo de S. Miguel impõe às mulheres portuguesas, ainda que elas mesmas não apresentem consciência de sua condição (como ocorre com Maria Luíza ${ }^{53}$ ), as escolhas da autora implícita a que obedece a narradora irão apresentar na narrativa essa

\footnotetext{
${ }^{53}$ Como sabemos, há uma coincidência de nome entre essa personagem de $A$ llha Verde e a personagem de Lúcia Miguel Pereira. Nota-se que para fim de distinção entre elas, em Lúcia Miguel o nome é grafado com s (Maria Luísa), enquanto em Maria Lamas é grafado com z (Maria Luíza).
} 
consciência a partir da observação. Subverte-se aqui também a estrutura social sob a qual o romance está circunscrito, não só pela escolha específica por essa protagonista estrangeira que tem mais liberdade que as outras, mas principalmente porque, em se contrastando com as outras, expõe de maneira crítica a condição dessas mulheres. A narradora, assim, embora não assuma o ponto de vista de llonka, aloca-se entre essa e a outra, na figuração de Maria Luíza, e será mediadora desta relação, apresentando os pormenores de uma parte e de outra e fazendo emergir na narrativa questões bastante caras, e que vinham sendo cada vez mais oprimidas, para o feminismo no momento. A ruptura com o ideal de casamento, e a função da mulher como mãe e esposa, encontra representação em llonka, mas como ela é o diferente naquele contexto se estabelece em contraposição à Maria Luíza, que estava completamente submetida ao casamento como única alternativa de vida, portanto, à obediência ao modelo.

Assim, a narradora de $A$ Ilha Verde parece responder ao entrelaçamento de uma ideologia feminista, que prospecta a emancipação da mulher sem, no entanto, romper totalmente com a ideologia patriarcal, que estabelece a função da mulher acondicionada na esfera familiar sob as ordens de um marido através das personagens portuguesas. Se Marta de Para além do amor não consegue libertarse disso, mas arranja uma maneira de subverter e para isso conta-nos sua história em primeira pessoa, a narradora de $A$ Ilha Verde vai apontar uma liberdade possível numa estrangeira que iluminará o avesso a realidade da mulher portuguesa na figura de Maria Luíza. É importante notarmos que durante o final dos anos 1930 o regime salazarista tomava ainda um caráter mais autoritário, e talvez isso determine as diferenças latentes entre a autora implícita de Para além do amor, que permite a sua narradora vislumbrar um futuro mais emancipado, e a autora implícita de $A$ Ilha Verde, que permite a sua narradora observar e expor as diferenças através do contraste, com um final contrastante também entre duas personagens, uma vez que llonka segue em sua liberdade, qualquer que seja o seu estado de espírito ela poder sair e sai da "tentativa de prisão", em contraste com Maria Luíza a quem sempre restou a espera. Sobre isso, diz-nos Ferreira:

Seja ou não estratégica para evitar o impacto da censura, o uso de uma personagem estrangeira reclamando o direito ao prazer sexual é sugestiva da distância entre a mulher livre "lá de fora" ou, antes, 
um seu estereótipo artístico e publicitário (constituindo o "falso feminino"), e mulheres portuguesas vivendo realidades concretas diversas relativas a meio-ambiente, a classe social, a nível de educação, de formação religiosa, etc. É a estas mulheres - aquelas que, simbolicamente, Ilonka deixa atrás em $\mathrm{S}$. Miguel sem que a sua passagem pela ilha tivesse alterado as suas vidas - que Maria Lamas dedicará a sua atenção como jornalista e como intelectual a partir de meados dos anos quarenta, numa altura em que se começará a afirmar publicamente como feminista mas, primeiro que tudo, como democrata - uma tomada de posição corajosa que a levará à prisão, como se sabe e, eventualmente, ao exílio. (FERREIRA in MARQUES, 2004, p. 37)

Por sua vez, se em Maria Luísa evidencia-se uma narradora que muda de posicionamento a partir da tomada de consciência da protagonista, indicando uma defesa (ou ao menos cumplicidade) com a nova consciência que se forma, ainda que não vislumbre desfecho feliz senão conformado, em Amanhecer há uma emancipação da voz da narradora, aqui protagonista, ao longo da narrativa que resultará numa análise crítica com relação a tudo que lhe está em volta, inclusive o amor. Também não há desfecho feliz, mas um posicionamento através do qual se propõe que a consciência é importante até para melhor entender os limites da função social, dimensionada pela sociedade para além da prospecção no relacionamento amoroso. Assim, as autoras implícitas de Lúcia Miguel Pereira, às quais obedecem suas narradoras, não apontam para uma saída, mas sim para um processo de readequação, que não rompe, mas também, dentro das suas medidas possíveis, buscam subverter a ordem estabelecida.

Torna-se imprescindível uma alusão à ideologia feminista do período e aquilo que elas correspondem como contraideologia à ideologia patriarcal. A diferença reivindicativa entre o feminismo português e o brasileiro dos anos 1930 parece-nos apontar para uma dinâmica peculiar em cada um dos contextos. Em Portugal, o feminismo vinha sendo fortalecido desde o início do século no que reivindicava de emancipação feminina. Nesse sentido, pulsava ali mais forte a questão do trabalho das mulheres (principalmente as mulheres burguesas, visto que se tratava principalmente de um movimento burguês), mas que, todavia, aponta para a problemática situação da dependência econômica como uma maneira de cercear a 
liberdade da mulher. Não se propunha uma ruptura total com o casamento e a família, tampouco recaía sobre isso as críticas mais contundentes, mas ao assumir um posicionamento crítico à prisão da mulher ao lar, claro está que havia também uma oposição em relação aos papéis tradicionais das mulheres. Também versava sobre a instrução feminina. E o divórcio era reivindicado, o que foi atendido (e depois retrocedido) nos anos 1910. Isso parece responder à maior flexibilidade de ação que têm as protagonistas dos romances de Maria Lamas, e, consequentemente, as suas narradoras. Assim, Marta não será uma mulher casada a quem só resta a resignação, ainda que corresponda à esfera de submissão a qual está, inevitavelmente, submetida, porque ainda que não escolha o divórcio, uma vez que isso teria implicações na relação com seu filho, pode vislumbra-lo. Tem, de alguma maneira, a escolha e essa escolha impulsiona a sua ação. E Ilonka já estará correspondendo à ideologia feminista à frente do tempo português, uma vez que se recusa ao casamento, radicalizando então o posicionamento. Não é uma mulher portuguesa e não altera a dinâmica das mulheres da Ilha, a não ser a de Maria Luíza, que será o seu oposto e que, no contraste, vai apresentar a faceta mais poderosa da ideologia patriarcal que submete a mulher ao desígnio de um homem, num período em que Salazar recrudesce as políticas de repressão à mulher. As autoras implícitas de Maria Lamas, que organizam e intermediam a relação das narradoras na trama, despontam como mais radicais.

Por sua vez, no Brasil, o feminismo correspondente aos anos 1930 reivindicava também a instrução como fator primordial, mas o trabalho não tem, ainda, tanta ênfase no começo da década como no final, principalmente para a mulher burguesa. Então Maria Luísa não tem outra saída que não se resignar e voltar para a mesma função que tinha antes, de esposa e mãe, agora, no entanto, sem nenhuma autoridade, completamente submetida e resignada, porque consciente de sua opressão entende que não pode sair dela. No entanto, nos anos finais desta década, a protagonista que desponta não é mais a mulher burguesa, pelo contrário, será uma mulher pobre que teve acesso à educação e que almeja, não fossem seus pais um empecilho, desde o início uma independência econômica. Isso é possível porque em sua classe as mulheres trabalham. Mas ainda é pressionada pela ideologia patriarcal que condiciona às mulheres ao amor de um homem e, mesmo que Maria Aparecida não case, irá manter-se subjugada a Antônio, o que a narradora revê enquanto escreve, porque já o critica a partir de 
agora, ainda que também ao final do romance não vislumbre destino feliz, faz-se claro que sua consciência tomou uma nova dimensão da qual não pode retroceder. Assim que:

\begin{abstract}
Mas nessa ocasião eu não sabia ainda quanto tinha mudado. Só me dava conta do que havia de novo em mim, dessa consciência mais nítida que eu adquirira de todos os problemas, dessa revelação de tantos aspectos que ignorava. Mas não sabia que tinha havido mortes dentro de mim, que eu carregava - carrego ainda - um cadáver que me envenena. O da Maria Aparecida, afilhada de Nossa Senhora da Aparecida, protegida da morta da Casa Verde. (PEREIRA, 2006, p. 323).
\end{abstract}

Assume um radicalismo, ainda que não the seja totalmente libertário também, significativo com relação à Maria Luísa, escancarando que agora a ordem que opera também é outra, a autora implícita dá a sua protagonista a possibilidade de ser a sua própria narradora. Maria Aparecida fala por si e através dela observamos suas escolhas para além do que ela própria impõe crítica, porque isso nos permite a autora implícita na organização dos eventos narrados que não decorrem de uma crítica da narradora, mas que dão dimensão crítica ao romance.

Assim, parece-nos adequado lembrar, finalizando aqui esta comparação, o que dizia em 1928 Virgínia Woolf sobre as escritoras aspirantes, porque dialoga com o que é projetado sobre as mulheres dos anos 1930, tanto em Brasil quanto em Portugal:

Você não pode fazer isso e não vai fazer aquilo! Não aceitamos senhoras sem carta de recomendação! Graciosas romancistas aspirantes, por aqui! Assim eles estavam em cima dela como a multidão nas cercas em dia de páreo, e o teste consistia em ultrapassar o obstáculo sem olhar para a direita ou a esquerda. Se parar para praguejar, estará perdida, eu disse a ela; a mesma coisa se parar para rir. Se hesitar ou se atrapalhar, estará acabada. Pense apenas no salto, implorei, como se tivesse apostado todo meu dinheiro nela; e ela passou com um pássaro. Mas havia um obstáculo depois desse e outro obstáculo depois daquele. Se ela 
tinha o poder de aguentar, eu tinha minhas dúvidas, porque os aplausos e os gritos era de esfrangalhar os nervos. Mas ela fez o melhor que pôde. (WOOLF, 2014, p. 134)

Às mulheres cabia fazer o melhor que pudessem, ainda que sob as limitações que os contextos sociais thes impunham, para representar suas realidades. Tarefa essa a qual parecem responder Lúcia Miguel Pereira e Maria Lamas. 


\section{CONCLUSÃO}

A arte, a literatura, a filosofia são tentativas de fundar de novo o mundo sobre uma liberdade humana, como o criador. É preciso, primeiramente, se colocar sem equívoco como uma liberdade, para alimentar tal pretensão. As restrições que a educação e os costumes impõem à mulher limitam seu domínio sobre o universo. Quando o combate para conquistar um lugar neste mundo é demasiado rude, não se pode pensar em dele sair; ora, é preciso primeiramente emergir dele numa soberana solidão, se se quer tentar reapreendêlo. (BEAUVOIR, 2016b, p 536)

Os romances de Lúcia Miguel Pereira e Maria Lamas trazem à tona questões acerca das condições de vida das mulheres na década de 1930. Por apontarem para um campo ideológico em que sobressaem a ideologia patriarcal em dialética, pois sob contestação, com certa ideologia feminista do período, as narradoras se definem como tal. As especificidades dessas narradoras tangenciam o contexto social e histórico sob os quais foram criadas. Assim, as protagonistas tomam posicionamentos mais radicais nos romances do final dos anos 1930 , quando tanto a ditadura Salazarista quanto a Varguista recrudesciam suas políticas para as mulheres.

A questão do casamento vem apresentar essa dinâmica. Dessa forma, enquanto no início dos anos 1930, o enredo se desdobrará a partir do adultério de mulheres casadas, no final dos anos 1930, as mulheres irão recusar o casamento. As narradoras tomam diferentes posicionamentos: aproximam-se ou distanciam-se, assumem o foco narrativo em primeira ou terceira pessoa. Tudo isso, orquestrado por autoras implícitas, dá o tom com o qual elas irão responder aos contornos de determinada representação social. Se não são narradoras que investem numa ruptura total com a ideologia patriarcal, vão contestá-la a partir de uma perspectiva feminista, naquilo que Ihes é possível circunscritas aos seus contextos. Assim, temos que, embora elas tenham especificidades que procuramos apontar, o campo ideológico em que atuam é comum, porque a condição das mulheres que observam e acompanham ou são também tem aspectos comuns. 
Simone de Beauvoir afirmou que basta uma crise política, religiosa ou econômica para que os direitos das mulheres sejam questionados, por isso devemos nos manter vigilantes desses direitos initerruptamente. É difícil versar conclusivamente sobre o que foi postulado nesta tese eximindo-se de observar o presente. Se conseguimos provar que as ideologias presentes nas estruturas narrativas definem a narradora na condição social de mulher, caberia nos perguntar se ocorreram mudanças significativas nesse campo ideológico para que a observemos hoje, do que se sobrepõe e do que, em se evidenciando, podemos contestar.

O que observamos atualmente é uma sensível presença do feminismo no Brasil e em Portugal. No entanto, no Brasil, local em que esteve abrigada esta pesquisadora e esta pesquisa, um presidente eleito ${ }^{54}$ defende publicamente que mulheres devem de fato ter salários inferiores aos homens, por serem mulheres. Além disso, o nome indicado para ministro da educação ${ }^{55}$ afirma em entrevista que "educação de gênero" é uma "função deletéria", ao defender um projeto chamado Escola Sem Partido. É verdade que foram realizadas importantes conquistas pelo movimento de mulheres, no entanto, como já fomos alertadas, tais conquistas nunca estão suficientemente asseguradas.

Assim, pensamos que a conclusão desta tese poderia ser feita na voz de Maria Lamas, em uma carta carregada por seu desabafo, a quem passamos a palavra:

Libertar-me! Libertar-me de tudo, até de mim própria - as ideias feitas, os atavismos das convenções, os sentimentalismos doentios, o apego ao conforto - como eu queria poder fazê-lo. E mais do que tudo, as minhas energias num trabalho que é a negação das minhas próprias possibilidades e do dever que me impõe a vida que vivi. Quem conhece, como eu, a Vida, e sofreu, e lutou, amou e errou

${ }^{54} \mathrm{Em}$ outubro de 2018, Jair Bolsonaro foi eleito presidente do Brasil. Durante sua campanha, alavancada por diversas polêmicas, ele afirmou em diversas ocasiões, incluindo em um canal de TV aberto, que as mulheres devem ter salários menores do que os homens. Cf. em: $<<$ https://www.youtube.com/watch?v=RvVc4hbHWOg >>. Acesso em: 28 ago. 2018.

${ }^{55}$ Foi indicado para Ministro da Educação o professor colombiano da Escola de Comando e estado maior do Exército Ricardo Vélez Rodríguez. Disponível em: $<$ https://noticias.uol.com.br/politica/ultimas-noticias/2018/11/22/bolsonaro-anuncia-ricardo-velezrodriguez-ministro-daeducacao.htm?cmpid=copiaecola\&fbclid=IwAR3mNRIHLeF2YvGNbU3YJ5Aj7LYflqd5pKKDaXoNxaE _Z11LK21edJgrpXo>>. Acesso em: 22 nov. 2018. 
como eu, tem o dever de gritar aos outros a sua experiência não como um aviso - nunca a experiência dos outros aproveitou ao semelhante - mas como um depoimento de sinceridade no labirinto de mentiras e aparências em que todos andamos metidos. $E$ eu não posso, por motivos mais fortes que todos os meus desejos, soltar esse grito e deixar o sinal da minha passagem, dizer a minha verdade. É este um tormento que nem sequer me atrevo a confessar. Lisboa, 7 de setembro de 1943. (LAMAS, 2004, p. 24-25) 


\section{REFERÊNCIA BIBLIOGRÁFICA}

ABDALA JUNIOR, Benjamin. A escrita Neo-Realista. São Paulo: Ática, 1981. ABDALA JUNIOR, Benjamin. A escrita Neo-Realista. São Paulo: Ática, 1981. ADORNO, Theodor W. Notas de literatura I. São Paulo: Duas Cidades, 2003. ALMEIDA, A. M. (Org.); Maria José Carneiro (Org.); PAULA, S. G. (Org.). Pensando a família no Brasil: da Colônia à modernidade. $1^{\text {a }}$. ed. Rio de Janeiro: Espaço \& Tempo; Editora da Universidade Rural, 1987.

ALMEIDA, Edwirges A. Marcas da Tradição no tecido narrativo de Maria Luíza, de Lúcia Miguel Pereira. In: Eutomia Revista Online de Literatura e Linguística, Recife, v. 1, n. 3, p. 230-244, jul. 2009.

. O legado ficcional de Lúcia Miguel Pereira: escritos da tradição. Florianópolis: Editora Mulheres, 2011.

ARMSTRONG, Nancy. Deseo y ficción doméstica. Coy, María (trad.). Madri: Cátedra, 1991.

BAKHTIN, Mikhail. Questões de literatura e de estética. São Paulo: Hucitec Editora, 2010.

BALIBAR, Étienne; MACHEREY, Pierre; KRISTEVA, Julia et al. Literatura, significação e ideologia. Lisboa: Arcádia, 1976.

BEAUVOIR, Simone. O segundo sexo. 2 v. Rio de Janeiro: Nova Fronteira, 2016.

BELO, Maria; ALÃO, Ana Paula; CABRAL, Iolanda Neves. O Estado novo e as Mulheres. In: Colóquio Sobre O Estado Novo, 1987, Lisboa. O Estado Novo das origens ao fim da autarquia. Lisboa: Editorial Fragmentos, 1987, v. II, 405p.

BENJAMIN, Walter. Obras escolhidas I: Magia e técnica, arte e política. 2. ed. São Paulo: Brasiliense, 1987.

BESSE, Susan K. Modernizando a desigualdade: reestruturação da ideologia de gênero no Brasil: 1914-1940. São Paulo: EDUSP, 1999.

BIBLIOTECA NACIONAL. Maria Lamas 1893-1983. Lisboa: Inst. Biblioteca Nacional, 1993.

BIROLI, Flávia; Miguel, Luis Felipe. Feminismo e política. São Paulo: Boitempo, 2014.

BOOTH, Wayne. A retórica da ficção. Lisboa-Portugal: Ateliê Arcádia, 1980. 
BOSI, Alfredo. Ideologia e contraideologia. São Paulo: Companhia das Letras, 2010. . Literatura e resistência. São Paulo: Companhia das Letras, 2002.

BOURDIEU, Pierre. A dominação masculina. Tradução de Maria Helena Kuhner. Rio de Janeiro: Bertrand Brasil, 2010.

BRAIT, Beth. A personagem. São Paulo: Editora Ática, 2000.

BRANCO, Lúcia Castello; BRANDÃO, Ruth Silviano. A mulher escrita. Rio de Janeiro: Lamparina, 2004.

. O que é escrita feminina. São Paulo: Brasiliense, 1991. (Coleção

Primeiros Passos.)

BRANDÃO, Ruth Silviano. A mulher ao pé da letra: a personagem feminina na literatura. Belo Horizonte: Editora da UFMG, 2006.

BRATER, Enoc (org.). Feminine focus: the new women plawright. New York: Oxford University Press, 1989.

BRUSCHINI, Cristina. Mulher, casa e família. São Paulo: Vértice, 1990.

BUENO, Luís. Uma história do romance de 30. Campinas: Editora Unicamp, 2006.

BURKE, Peter. A escrita da história. São Paulo: Ed. Unesp, 1992

CAMARA, Elisabete Vieira. A forma do ensaio e a construção do tempo ficcional em Lucia Miguel Pereira e Virginia Woolf. 2011, 199f. Tese (Doutorado). Faculdade de Filosofia, Letras e Ciências Humanas, Universidade de São Paulo, 2011.

CÂNCIO, Fernanda. A grande Revolução esquecida no 25 de abril. In: Diário de Notícias, Lisboa, 25 abr. 2016. Disponível em: < https://www.dn.pt/portugal/interior/a-grande-revolucao-esquecida-do-25-de-abril-

5142798.html >>. Acesso em: 17 out. 2016.

CANDIDO, Antonio. O discurso e a cidade. 4. ed. São Paulo: Ouro sobre azul, 2010. . Literatura e sociedade. Rio de Janeiro: Ouro sobre azul, 2006. . O albatroz e o chinês. Rio de Janeiro: Ouro sobre azul, 2004. . Tese e antítese. Rio de Janeiro: Ouro sobre azul, 2006

CANEVACCI, Massimo. Dialética da família: gênese, estrutura e dinâmica de uma instituição repressiva. São Paulo: Brasil 1976.

CHRISTIANO DE SOUZA, Maria Cecilia Cortez. Crise familiar e contexto social: 1890-1930. Bragança Paulista: EDUSP, 1999.

CORDEIRO, Célia Carmen. Ana de Castro Osório e a mulher republicana portuguesa. Lisboa: Fonte da Palavra, 2012. 
COUTINHO, Fabio de Sousa. Lucia: uma biografia de Lucia Miguel Pereira. Brasília: Outubros Edições, 2017.

D'INCAO, Maria Ângela. Mulher e família burguesa. In: DEL PRIORE, Mary (org.). História das Mulheres no Brasil. São Paulo: Contexto, 2017, p. 223-240.

DACANAL, José Hildebrando. A literatura brasileira no século $X X$. Porto Alegre: Mercado Aberto, 1984.

DAL FARRA, Maria Lúcia. O narrador ensimesmado. São Paulo: Ática, 1978.

DAVIS, Angela. Mulher, raça e classe. São Paulo: Boitempo, 2016.

DUARTE, C. L. Lúcia Miguel Pereira revisitada. In: ALMEIDA, E. A. R. L. O legado ficcional de Lúcia Miguel Pereira. Florianópolis: Editora Mulheres, 2011.

DUBY, G., Perrot, M. História das Mulheres: O Século XX. Porto: Edições Afrontamento, 1995.

EAGLETON, Mary. Feminist criticism. Cambridge: Blackwell Published, 1988.

EAGLETON, Terry. Teoria da Literatura: uma introdução. São Paulo: Martins Fontes, 2006. . Ideologia. São Paulo: Boitempo, 1997.

ELEUTÉRIO, Maria de Lourdes. Vidas de romance: as mulheres no exercício de ler e escrever do entresséculos, 1890-1930. Rio de Janeiro: Topbooks, 2005.

ENGELS, Friedrich. A origem da família, da propriedade privada e do Estado. Leandro Konder (trad.). Rio de Janeiro: Civilização Brasileira, 1985.

ESTEVES, João. As origens do sufragismo português. Lisboa: Editorial Bizânico, 1998.

ESTEVES, João. Conselho Nacional de Mulheres Portuguesas. Revista Faces de Eva Estudos sobre a Mulher, Lisboa, n. 15, s.p., 2006.

FEDERIC, Silvia. Caliban y las brujas. Buenos Aires: Tinta Limón, 2015.

FELSKI, R. Literature After Feminism. Chicago: The University of Chicago Press, 2003.

FERREIRA, Ana Paula. Maria Lamas e o Mito do Amor Romântico. In: MARQUES, R. A memória, a obra e o pensamento de Maria Lamas. Porto: Edições Colibri, 2004. FIANDEIRO, M. A. Maria Lamas - Biografia. Lisboa: Quetzal Editores, 2003.

. Maria Lamas: uma mulher em pessoa. In BIBLIOTECA Nacional. Maria Lamas 1893-1983. Lisboa: Instituto da Biblioteca e do Livro, 1993.

GOLDMANN, Lucien. A sociologia do romance. Rio de Janeiro: Paz e Terra, 1976. 
GRAMSCI, Antonio. Os intelectuais e a organização da cultura. Rio de Janeiro: Civilizações Brasileira 1978.

GUIMARÃES, Elina. A mulher portuguesa na legislação civil. In: Análise Social, v. XXII, n. 92-93), 1986, p. 557-577. Disponível em: <<http://www.egov.ufsc.br/portal/sites/default/files/anexos/3235338887-1-PB.pdf>>. Acesso em: 10 fev. 2017.

. Movimento feminista. Lisboa: Edição fac-similada de Civilização, 1930.

HOBSBAWN, Eric. Nações e nacionalismo desde 1780. 5. ed. São Paulo: Paz e Terra, 2008.

HOLANDA, Sérgio Buarque de. Raízes do Brasil. São Paulo: Companhia das Letras, 1995.

HUMPHREY, Robert. O fluxo de consciência. São Paulo: McGraw-Hill do Brasil, 1976.

HUTCHEON, Linda. Teoria e política da ironia. Belo Horizonte: Editora da UFMG, 2000.

INVERNO, C. R. C. A mulher no país de Maria Lamas: a questão sem nome na obra Para além do amor. 2010. 76f. Dissertação (Mestrado). Universidade Nova Lisboa, Lisboa, 2010.

JAMES, Henry. Pelos olhos de Maisie. São Paulo: Companhia das Letras, 2010.

JAMESON, Fredric. O inconsciente político - a narrativa como ato socialmente simbólico. São Paulo: Ática, 1992.

Marxismo e forma: teorias dialéticas da literatura no século 20. São

Paulo: Hucitec, 1985.

JOERES, Ruth-Ellen; MITTMAN, Elizabeth. The politics of the essay. EUA: Indiana University Press, 1993.

KAYSER, Wolfgang. Análise e interpretação da obra literária. Coimbra-Portugal: Armênio Amado Editora, 1985.

KONDER, Leandro. A questão da ideologia. São Paulo: Companhia das Letras, 2002.

LAMAS, Maria. A Ilha Verde. Lisboa: Editorial O Século, 1938.

. A mulher no mundo. Rio de Janeiro, Lisboa: Livraria Editora da Casa do Estudante do Brasil, 1952.

. As mulheres do meu país. Lisboa: Editorial Caminho, 2003.

. O caminho Iuminoso. Porto: Livraria Civilização, 1928.

. Para além do amor. Lisboa: Parceria, 2003.

LANE, Silvia T. Maurer. O que é psicologia social. São Paulo: Brasiliense, 2006. 
LEITE, Míriam Lifchitz Moreira Leite. Outra face do feminismo: Maria Lacerda de Moura. São Paulo: Ática, 1984.

LOURENÇO, António Apolinário; REIS, Carlos. História crítica da literatura portuguesa: o Modernismo. Lisboa: Verbo, 2015.

LUKÁCS, Gyorgy. A teoria do romance. São Paulo: Editora 34, 2009. . Marxismo e teoria da literatura. São Paulo: Expressão Popular, 2010.

MACEDO, Ana Gabriela. Género, identidade e desejo. Lisboa: Cotovia, 2002.

MADEIRA, João. Vítimas de Salazar. Estado novo e violência política. Lisboa: A esfera do Livro, 2007.

MANNONI, Maud. Elas não sabem o que dizem. Trad. Lucy Magalhães. Rio de Janeiro: Jorge Jahtar Ed., 1999.

MARQUES, Regina. (org.). A Memória, a obra e o pensamento de Maria Lamas. Porto: Edições Colibri, 2004.

MARX, Karl; ENGELS, Friedrich. A ideologia alemã. São Paulo: Boitempo, 2007.

MAURÍCIO, Maria José. Mulheres e cidadania: alguns perfis e acção política, 19491973. Lisboa: Caminho, 2005.

MÉSZÁROS, István. Filosofia, ideologia e ciência social. São Paulo: Editora Ensaio, 1993.

O poder da ideologia. São Paulo: Boitempo, 2012.

MILLER, Beth. Uma consciência feminista: Rosário Castellanos. São Paulo: Editora Perspectiva, 1987.

MOORE, Henriqueta. Feminism and antropology. Cambridge: Polity Press, 1988.

MORAES, Marcia. Ser humana: quando a mulher está em discussão. Rio de Janeiro: DP\&A, 2002.

MORENTE, Marcela C. O. Invadindo o mundo público. São Paulo. Humanitas, 2017. MORETTI, Franco (org.). A cultura do romance. São Paulo: Cosac Naify, 2009. MOTT, Maria Lúcia de Barros. Biografia de uma revoltada: Ercília Nogueira Cobra. In: Caderno de Pesquisa, n. 58, São Paulo, ago. 1986. p. 89-102.

NUNES, Maria José Rosado. Freiras no Brasil. In: PRIORE, Mary Del. História das mulheres no Brasil. São Paulo: Contexto, 2017.

OLIVEIRA, Maria T. M. A mulher e o adultério: nos romances de O Primo Basílio de Eça de Queirós e Effi Briest de Theodor Fontane. Porto: Livraria Minerva, 2000. OSÓRIO, Ana de Castro. Às mulheres portuguesas. Lisboa: Livraria Editora Viúva Tavares, 1905. 
PAVANELO, Luciene; SIMON, Maria C. P.; OLIVA, Osmar Pereira; MOTTA, Paulo (orgs). Marginalidades femininas: a mulher na literatura e na cultura brasileira e portuguesa. Montes Claros: Unimontes, 2017.

PEREIRA, Lúcia Miguel. A leitora e seus personagens: seleta de textos publicados em periódicos (1931-1943). Luciana Viegas (org.). Rio de Janeiro: Graphia Editorial, 1992.

- Escritos da maturidade: seleta de textos publicados em periódicos (1944-1959). Luciana Viegas (org.). Rio de Janeiro: Graphia Editorial, 1994. . Ficção reunida. Curitiba: Editora da UFPR, 2006. - Machado de Assis: estudo crítico e biográfico. São Paulo: Editora Brasileira, 1949.

PERROT, Michelle. Os excluídos da história. Rio de Janeiro: Paz e Terra, 1988.

PIMENTEL, Irene Flunser. História das organizações femininas do Estado Novo. Lisboa: Temas e Debates, 2001.

PINTO, Céli Regina Jardim. Uma história do feminismo no Brasil. São Paulo: Editora Fundação Perseu Abramo, 2003.

PRADO JR., Caio. Formação do Brasil contemporâneo. São Paulo: Companhia das Letras, 2012.

PRIORE, Mary Del. História das mulheres no Brasil. São Paulo: Contexto, 2017. . História do amor no Brasil. São Paulo: Contexto, 2015.

RABINOWITZ, N.; RICHLIN, A. Feminist theory and the classics. New York: Routledge, 1993.

RAGO, Margareth. Do cabaré ao lar: a utopia da cidade disciplinar Brasil 1890-1930. Rio de Janeiro: Paz e Terra, 1985. . Trabalho feminino e sexualidade. In: DEL PRIORE, Mari. História das mulheres no Brasil. São Paulo: Contexto, 2017. p. 578-606.

REICH, Wilhelm. A revolução sexual. São Paulo: Círculo do Livro, 1966.

REIS, Carlos. O discurso ideológico do neo-realismo português. Coimbra: Livraria Almedina, 1983.

RIBEIRO, Djamila. O que é lugar de falar? Belo Horizonte: Letramento, 2017.

ROCHA, Clara. Máscaras de Narciso: estudos sobre a literatura autobiográfica em Portugal. Coimbra: S.N., 1992. 
RODRIGUES, Mariline Direito. Mulheres e cidadania na revista Modas \& Bordados. Representação de um percurso de mudança entre 1928-1947. 2016. Dissertação (Mestrado em Jornalismo) - Escola Superior de Comunicação Social, Lisboa.

ROONEY, Ellen. The Cambridge companion to feminist literary theory. Cambridge: Cambridge University Press, 2006.

RUTHVEN, K.K. Feminist Literary studies: an introduction. Cambridge: Cambridge University Press, 1991.

SAFFIOTI, Heleieth. A Mulher na sociedade de classes. São Paulo: Expressão Popular, 2013.

Gênero patriarcado violência. 2.ed. São Paulo: Expressão Popular: Fundação Perseu Abramo, 2015.

SAID, Edward W. Arte e representação da realidade no romance português contemporâneo. São Paulo: Quíron, 1979.

SAID, Edward W. Cultura e política. São Paulo: Boitempo, 2007.

SANTOS, Juliana. Ficção crítica de Lúcia Miguel Pereira: a literatura como formação. 2012, 236f. Tese (Doutorado). Instituto de Letras, Universidade Federal do Rio Grande do Sul. Porto Alegre, 2012.

SCHWARCZ, Lilia M.; STARLING, Heloisa M. Brasil: uma biografia. São Paulo: Companhia das Letras, 2015.

SCOTT, Joan Wallach. Género e historia. México: UACM, 2008.

SECCO, Lincoln. A revolução dos cravos. São Paulo: Alameda, 2004.

SHOWALTER, Elaine. The new feminist criticism. Nova York: Patheon Books, 1985.

SILVA, Maria Regina Tavares da. Feminismo em Portugal: na voz de mulheres do início do séc. $X X$. Lisboa: Comissão para a Igualdade e para os Direitos das Mulheres, 1992.

SOIHET, Rachel. Feminismo e antifeminismos. Rio de Janeiro: 7Letras, 2013.

SOUZA, Maria Cecília de. Crise familiar e contexto social: São Paulo, 1890-1930.

Bragança Paulista: EDUSF, 1999.

SWAIN, Gladys. A Alma, a mulher e o corpo - as metamorfoses da histeria no fim do século XIX. In: O feminismo: aproximações. Joel Birman e Carlos Augusto Nicéas (org.). Rio de Janeiro: Campus Ltda, 1986.

TENGARRINHA, José (coord.). A historiografia portuguesa, hoje. São Paulo: Editora Hucitec, 1999.

TORRES, Guillermo. Historia de las literaturas de vanguarda. Madri: Guadarrama, 
1971.

VAQUINHAS, Irene. Nem gatas borralheiras, nem boneca de luxo: as mulheres portuguesas sob o olhar da história (séculos XIX-XX). Lisboa: Livros Horizontes, 2005.

VASCONCELOS, Sandra. A formação do romance inglês. São Paulo: Aderaldo \& Rothscild; Fapesp, 2007.

VICENTE, Ana. As mulheres em Portugal na transição do milênio. Lisboa: Multinova, 1998.

WATT, lan. A ascensão do romance. São Paulo: Companhia das Letras, 1990.

WILLIAMS, Raymond. Cultura e sociedade: 1780-1950. São Paulo: Editora Nacional, 1960.

WOLLSTONECRAFT, Mary. Reivindicação dos direitos da mulher. São Paulo: Boitempo, 2016.

WOOLF, Virginia. Um teto todo seu. São Paulo: Tordesilhas, 2014. 